UNIVERSIDAD DE BURGOS

Facultad de Humanidades

Departamento de Filología
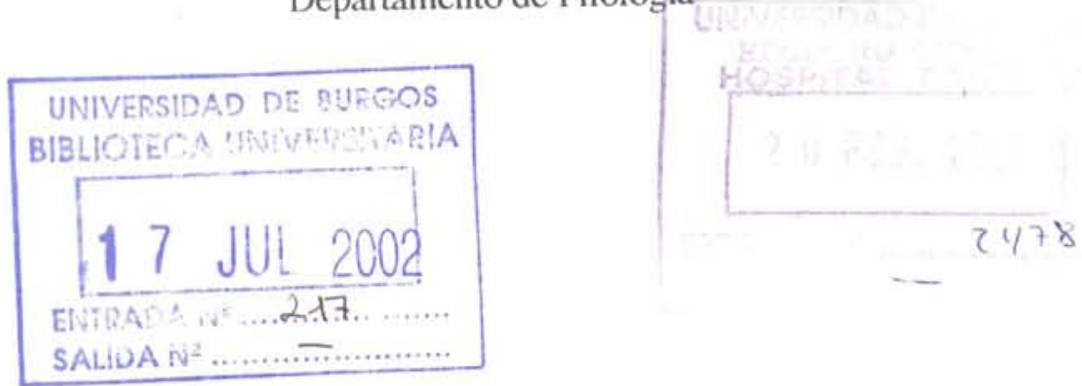

\title{
AUSTIN CLARKE: VARIANTES Y EVOLUCIÓN DEL CONFLICTO EN SU POESÍA
}

Tesis doctoral realizada por Leonardo Pérez García, bajo la dirección de la Dra. Inés Praga Terente

Burgos, febrero del año 2001 
b10985025

i111135511 


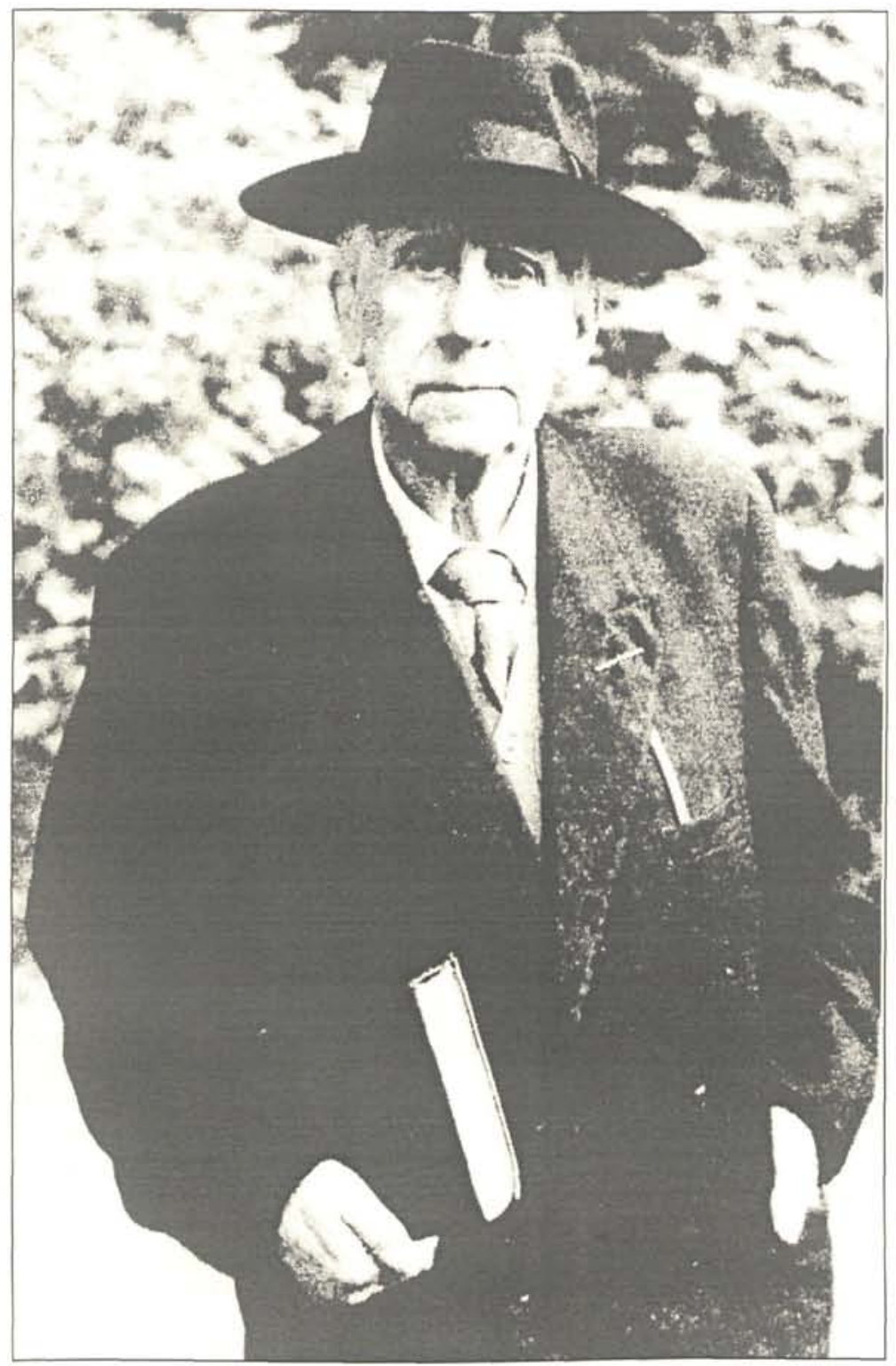

Austin Clarke 
Quan surts per fer el viatge cap a Itaca, Has de pregar que el camí sigui llarg, Ple d'aventures, ple de coneixences.

Tingues sempre al cor la idea d'Itaca.

Itaca t'ha donat el bell viatge, Sense ella no hauries sortit. I si la trobes pobra, no és que Itaca T'hagi enganyat. Savi, com bé t'has fet, Sabrás el que volen dire les Itaques. ("Viatge a Itaca" per Lluís Lach)

No abarateixis el somni, Que és com l'estel que hi ha al fons del camí. ("No Abarateixis el Somni" per Lluís Llach)

I've stumbled on the side on six crooked highways I saw a newborn baby with wild wolves all around it Heard one person starve, I heard many people laughing I met another man who was wounded in hatred I'm a-going back out 'fore the rain starts a fallin'. But I'll know my song well before I start sinkin'. It's a hard rain's a-gonna fall.

("A Hard Rain's a-Gonna Fall” by Bob Dylan)

"Then I'll be all aroun' in the dark. I'Il be ever'where - wherever you look. Wherever they's a fight so hungry people can eat, I'll be there. Wherever they's a cop beatin' up a guy, I'll be there. If Casy knowed, why, I'll be in the way guys yell when thay're mad an' - I'll be in the way kids laugh when they're hungry an' they know supper's ready. An' when our folks eat stuff they raise an' live in the houses they build - why, I'll be there. See? God, I'm talkin' like Casy. Comes of thinkin' about him so much. Seems like I can see him sometimes."

"I don' un'erstan'," Ma said. "I don't really know."

"Me neither," said Tom. "It's jus' stuff I been thinkin' about. Get thinkin' a lot when you ain't movin' aroun'.

(Grapes of Wrath by John Steinbeck) 


\section{Agradecimientos}

Hacer una lista de agradecimientos y no dejar a nadie fuera se me antoja tarea difícil. La realización de esta tesis no ha sido fruto de un simple programa de doctorado, que culminaría con un trabajo de investigación más o menos extenso. Si fuera así, estaría simplemente cumpliendo un expediente no sólo académico sino, en mi caso concreto, también profesional. Estas dos motivaciones, serias, dignas y respetables, se me quedan cortas. Esta tesis es el resultado de un proceso que no ha acabado, y que empezó un soleado día de alguno de los meses del curso 1971-72. Recuerdo que iba al colegio por la orilla del río y me encontré con una joven profesora que había dado un cursillo de inglés unos años antes en mi colegio y al que simplemente asistí y del que tan solo recuerdo haber aprendido una palabra: “gudifni”, sic. “¿Has seguido con el inglés?”, me preguntó. “No lo dejes”, añadió.

Un par de años más tarde, cuando cursaba el octavo grado de EGB, tuve la doble suerte de que mi familia me apuntara a un curso anual de inglés en una academia, y de que la profesora que impartía las clases fuese sencilla y llanamente excelente. Desde entonces no tuve que volver a preocuparme de estudiar, en el sentido estricto del término, inglés en mi vida, porque éste se convirtió ya en algo natural, en algo con lo que vivir, en una especie de deformación física con la que uno está condenado a vivir. Así, mi primer agradecimiento es para estas dos profesoras, cuyo nombre y fisonomía el tiempo se ha encargado de borrar, aunque no así su labor.

Han pasado muchos años desde entonces. Tomé rumbos equivocados, y quedé cautivo de las sirenas homéricas durante casi una década. En 1990 conseguí deshacer el hechizo y comencé la carrera de Filología Inglesa. Diez años más tarde, acabo esta tesis doctoral, cuya realización no ha sido solamente labor mía, sino también de aquellas personas que me acompañaron en el viaje, unas veces tendiéndome la mano, otras dándome un empujón lleno de ánimos, otras amenazándome 
con cortarme las orejas. Sé que algunos de los pasajeros de mi periplo académico se van a quedar fuera de estas páginas, y quiero antes de nada pedirles disculpas porque, aunque no aparezcan aquí de forma nominal, sí lo están de forma espiritual. Al escribir estas líneas me viene a la cabeza una serie de personas que han sido fundamentales tanto en la confección de esta tesis como en mi vida personal y profesional. Los primeros son Félix Luis González Ruiz y Nelson López de la Cal, amigos de la infancia, cuyos empujones anímicos no quedarán nunca en el olvido. Un agradecimiento especial a Pilar Cousido González, por lo que ella ya sabe. También, cómo no, a Bill Green, profesor de Inglés en una lejana universidad de Sapporo, y a Miriam Kingston, por su ayuda y paciencia. En el campo académico, quiero dar las gracias a Pilar Gómez, por aguantar mis idiosincrasias quinceañeras en el Instituto y, sobre todo, por haber creído en mí. Ya en la Universidad hay dos personas a las que estaré eternamente agradecido, no solo por confiar en mí, sino por su ayuda y amistad. La primera, Conchita Magariño, que casi me compró el billete para que me fuera a Irlanda con el programa Erasmus. Sin su consejo, seguramente no estaría aquí, y no habría conocido a Joyce ni, por supuesto, a Clarke. A la segunda, que no por estar en último lugar es menos importante - más bien todo lo contrario-, le brindo mi más sincero agradecimiento: Inés Praga Terente, por su ayuda, por su entusiasmo, por su amistad, y, simplemente, por estar ahí, al pie del cañón sin apenas parpadear.

Quiero, en estas líneas laudatorias, hacer mención especial a Jorge Santana, profesor del Departamento de Español de la Universidad de Sacramento, por su amistad y apoyo, y a Linda Palmer y David Bell, profesores del Departamento de Inglés de la misma Universidad, por sus consejos y enseñanzas. Por supuesto, muchas gracias a todos mis compañeros del Departamento de Filología Inglesa. 
is padres, por su paciencia y comprensión 


\section{ÍNDICE}

INTRODUCCIÓN.

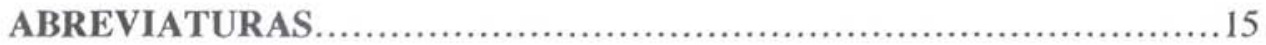

I. EL HOMBRE, EL ESCRITOR Y LA TRADICIÓN.................. 17

I.1. Austin Clarke: Apunte biográfico................................... 19

I.2. Austin Clarke y la Tradición......................................... 48

I.3. Austin Clarke y W. B. Yeats. ................................ 54

I.4. Austin Clarke y Jonathan Swift...................................61

I.5. Austin Clarke y James Joyce................................... 65

I.6. Austin Clarke y Patrick Kavanagh................................ 72

I.7. Austin Clarke y Thomas Kinsella..................................... 80

II. LA RELIGIÓN, LA CARNE, Y EL ESPíRITU........................ 85

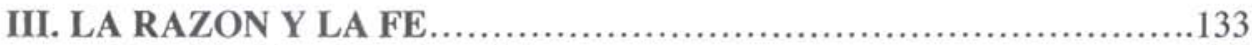

III.1. Conflicto Razón vs. Fe....................................... 137

III.2. “Ancient Lights”: ¿La liberación espiritual de Clarke?............. 170

III.3. "Martha Blake": La fe.........................................181

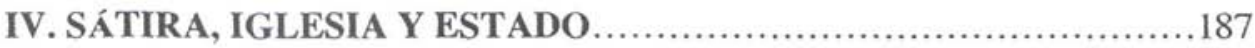

IV. 1. La Sátira en Irlanda..........................................189

IV.2. A. Clarke y las Instituciones: La Iglesia Católica ................ 199

IV.3. A. Clarke y las Instituciones: La Iglesia Católica y el Estado... 261

V. LA LOCURA: MNEMOSYNE LAY IN DUST ...................... 293

VI. CONCLUSIONES ............................................... 349

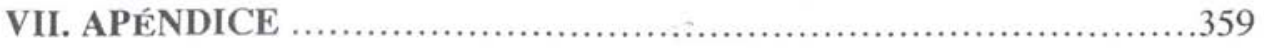

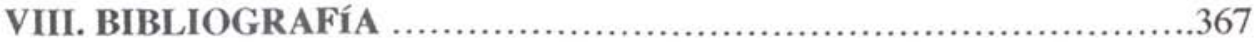


INTRODUCCIÓN 
Recuerdo con todo detalle cuando empecé la carrera de Filología Inglesa hace ya diez años exactos, y recuerdo también cómo algunos compañeros de cursos superiores comentaban a menudo que si James Joyce esto y que si James Joyce aquello, viniendo poco más o menos a decir que Joyce era un genio. Yo, que soy de naturaleza ligeramente escéptica, le pregunté a mi amigo Bill Green, cuya formación anglosajona me podría sacar de dudas, que quién era este afamado escritor. Así lo hice. Pero para él era tan sólo un autor que se caracterizaba más por su dificultad que por su supuesta genialidad. ¿Quién era, entonces, este dichoso Joyce del que todo el mundo hablaba y a quien apenas nadie había leído? Decidí averiguarlo.

España, que en mi opinión no es un país que destaque por promocionar a sus escritores, y menos aún a los foráneos, no me parecía el lugar apropiado para encontrarme con él, el mejor novelista del siglo XX, según las listas que figuran en la prensa especializada, si es que habría de encontrarme con él. Así que hice las maletas y con una beca Erasmus bajo el brazo me embarqué hacia la isla esmeralda, aunque no con la intención de encontrarme con Joyce, sino más bien con la de anotar una pequeña "itaka" más en mi cuaderno de Bitácora. Recalé en Cork, Irlanda, y quizá el destino o la suerte o el alma errante de Joyce en busca de acólitos quisieron que me encontrara literariamente con él - también con JJ \& Sons, pero esto es otra historia- en un curso monográfico de literatura angloirlandesa que ofrecía el departamento de Inglés de la universidad. Estudiamos Dubliners y Ulysses, y aunque los relatos no me impresionaron demasiado al 
principio, sí lo hicieron con creces los pocos capítulos que leí de Ulysses, sobre todo el número 13 - Nausicaa-, quizás no el mejor pero sí el primero que leí. Nunca había tenido una experiencia literaria similar, "and never will ash, oak or elm"1.

Sin yo saberlo entonces, los relatos de Dubliners habían dejado en los resquicios de mi mente - la Sra. Woolf diría, "in the warm corner of the mind's inglenook" 2 - un rescoldo latente que el tiempo se encargaría de avivar años más tarde. Cuando acabé la carrera, me embarqué nuevamente hacia costas angloparlantes, esta vez Sacramento, California, como lector de español, y dejé a Joyce y a los irlandeses varados en su isla glauca. Al cabo de un año, regresé; otra vez, el destino o la suerte o la casualidad, que vienen a ser lo mismo, quisieron que me volviera a reencontrar con la literatura irlandesa.

Inés Praga, directora de esta tesis doctoral, se encontraba a la sazón enfrascada en la confección del libro Una Belleza Terrible: La Poesía Irlandesa Contemporánea (1940-1995), cuyo manuscrito tuve la suerte de hojear antes de que entrara en imprenta. En él me encontré con Joyce, Yeats, Kavanagh, Clarke, MacNeice, Kinsella, Heaney y muchos otros autores irlandeses que pugnaban por ocupar un merecido hueco en la obra de la doctora Praga. Al volver la mirada hacia los relatos de Dubliners, y después de leer la biografía de Ellman de Joyce, me di cuenta de que éste era un autor vertebrado por la idea de conflicto - religioso,

\footnotetext{
' James Joyce. Ulysses, 13.167. “Ash, oak or elm: A proverbial expression for eternity" (Don Gifford et al 386).

2Virginia Woolf, "Street Hunting".
} 
político y personal. Leí a otros autores y me di cuenta de que muchos de ellos habían pasado por experiencias similares: ¿tendría esto algo que ver con su condición de irlandeses? Al fijarme más detenidamente en los nombres que pueblan la obra de la doctora Praga, me fijé en un autor poco conocido, cuyos hechos y escritos rezumaban la idea de conflicto sin ningún pudor, de forma muy similar a Joyce. Este autor era Austin Clarke, a quien vi como un escritor idóneo para protagonizar mi futura tesis doctoral, no solo por parecerme representativo de la relación a menudo traumática entre escritor e Irlanda, sino también porque era un autor ignorado y apenas estudiado. Si toda tesis doctoral ha de procurar aportar algo inédito, Austin Clarke cumplía este objetivo a la perfección.

Con este autor en la mente, hice las maletas de nuevo y puse rumbo hacia Cork y Dublín, con el propósito de recopilar información sobre él. Al amparo de la amabilidad del Departamento de Español de la Universidad de Cork, comencé mi investigación en la biblioteca, donde prácticamente encontré todo el material que necesitaba. El resto, lo conseguí en Trinity College, Dublín, donde tuve la suerte de charlar con Brendan Kennelly, personaje excéntrico y extrovertido con un buen puñado de volúmenes de poesía en su haber literario. Para él, la Irlanda finisecular no era la sombra de lo que fue décadas atrás. Destacó, entre otras cosas, la excelente libertad sexual de que disfruta la mujer irlandesa a las puertas del siglo XXI sin tener que soportar el índice reprobatorio de ninguna institución. Kennelly es un personaje popular. Caminar con él por la calle equivale a saludar a medio Dublín, pararse cada pocos metros para un qué tal, cómo estás, hasta la vista. Es 
una persona jovial, dicharachera, alegre, pese a todos los problemas de salud que ha padecido en los últimos años. En cierta ocasión, allá por los años sesenta, fue a visitar a Clarke y se encontró con que la casa donde éste residía había desaparecido, lo que dio origen al poema titulado, "The House is Gone". Entre anécdotas y comentarios de otros autores irlandeses me fue introduciendo un poco más en el mundo literario irlandés y, por supuesto, en el de Clarke. Aquellas lejanas ascuas, que yacían medio olvidadas, medio apagadas en mi mente, empezaban a reavivarse con los nuevos vientos que impulsaban mi nave en su periplo investigador.

Austin Clarke es un poeta difícil de clasificar, y su obra, como dice Kinsella,

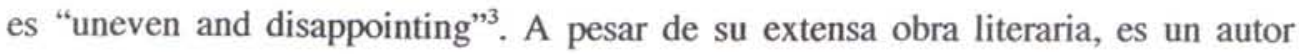
poco conocido, y ha permanecido en los anales literarios irlandeses poco menos que olvidado, sin apenas reconocimiento por parte de la crítica, que ha menospreciado su obra sin justificación alguna:

Austin Clarke has the tag of neglect pinned to his lapel like a badge of esteem. Neglect can have its own cachet. It is hard to see how Clarke can really be counted as such when three book-length studies have appeared. The demise of the Dolmen Press led to a long absence from the shelves; out of print, out of mind. ${ }^{4}$ (Brennan 3)

\footnotetext{
${ }^{3}$ Thomas Kinsella, Introduction ix.

${ }^{4}$ En realidad son cuatro los estudios que han aparecido publicados sobre la obra de Austin Clarke, y que aparecen detallados en la bibliografía de esta tesis: The Poetry of Austin Clarke, de Gregory A. Schirmer; Austin Clarke. A Study of His Writings, de G. Craig Tapping; Austin Clarke, de Maurice Harmon; y Austin Clarke: His Life and Works, de Susan Halpern.
} 
No obstante este inmerecido menosprecio, nos llamó la atención por tres razones principales: porque sirve de eslabón entre la poesía gaélica y la poesía del siglo $\mathrm{XX}^{5}$; por ser uno de los primeros autores en la Irlanda contemporánea que da voz a la frustración que los poderes fácticos irlandeses causaron en la mujer irlandesa; y, finalmente, porque acepta el reto joyceano de desenmascarar el capítulo de moralidad pública que representa Dubliners, y exponer lo que él denominaría "drama of racial conscience".

Si echamos un vistazo a la historia de Irlanda, vemos que uno de los temas que vertebran su idiosincrascia es el de conflicto, ya sea éste religioso, político o social. Casi desde el mismo momento en que el Cristianismo puso el pie en la Isla, la religión se convirtió en un constante punto de fricción. Primero entre Catolicismo y paganismo; más tarde, entre Catolicismo y Protestantismo; y siempre, entre la religión católica y la conciencia del individuo. El conflicto entre Inglaterra e Irlanda, colonizador y colonizado, se originó en el siglo $\mathrm{XVII}^{6}$, y desde

\footnotetext{
${ }^{5}$ Para Robert Welch, uno de los principales logros de la variada obra de Austin Clarke reside en la construcción del tono, de la calidad y de la variedad de la voz poética gaélica en inglés. Su obra "stands as an assertion of the continuity of Irish poetic tradition, in that he opens up all sorts of emotional and intellectual channels between different Gaelic pasts and the English-speaking Irish present"; asimismo, Welch ve la obra de Clarke como una traducción, en el sentido de que "his verse re-enacts in living English forms the craft and temper of Gaelic poetry" ("Austin Clarke and Gaelic Poetic Tradition" 41 ).

${ }^{6}$ Irlanda sufrió la primera invasión anglo-normanda hacia 1066, episodio que estableció una larga relación con la monarquía Inglesa. Desde entonces la relación de Inglaterra e Irlanda fue una incómoda mezcla de colonización y feudalismo. La primera implicaría dominación de una nación sobre la otra; la segunda, en cambio, una especie de patriarcado y colaboración mutua. A lo largo de los siglos, hasta 1541, el sistema que prevaleció fue el de tipo feudal, y los Señores irlandeses veían a Inglaterra como protectora. El siglo XVI trajo cambios, en parte debidos al poder marítimo isabelino, y, sobre todo, a la reforma protestante. El siglo XVII fue particularmente difícil para los católicos, especialmente el periodo entre 1649-58, en que Cromwell suprimió toda resistencia católica en la Isla. Más tarde, las Leyes Penales de 1695, se encargaron de concluir el proceso de colonización de la isla (cf. The Oxford Companion Irish History, 173, 128; O’Farrel, 1-5; Hurtley et al 64, 257).
} 
entonces hasta la Guerra de la Independencia de 1919, Irlanda luchó por romper los lazos que Inglaterra se empeñaba en atar y por crear un estado independiente. Este conflicto político creó a su vez revueltas sociales, como la Guerra Agraria - "the Land War" (1879-1903) -, entre terratenientes y arrendatarios, y, por supuesto, problemas de tipo económico, que ponían de relieve la diferencia entre la pobreza de Irlanda y la rapacidad y riqueza de Inglaterra. Y no hay que olvidar tampoco los problemas sociales que padeció Irlanda durante el siglo XX: además de la pobreza y el desempleo, la sanidad, la educación, y la vivienda, entre otros, fueron asuntos que necesitaban una constante revisión. Así, Austin Clarke, que ante todo es un hombre de su tiempo, no permanece ajeno al conflictivo rumbo que puso Irlanda especialmente durante las primeras décadas del siglo $\mathrm{XX}$-independencia y formación de la República de Irlanda - con todo lo que ello supuso para el país y para los irlandeses.

Austin Clarke escribió poesía, novela y teatro, y en cada uno de estos géneros aparece la idea de conflicto como uno de sus hilos conductores. Nosotros vamos a centrarnos en su poesía, y, concretamente, en aquellos poemas en los que el tema central es el de conflicto. Es nuestra intención mostrar en las páginas que siguen cómo el conflicto en la poesía de Clarke evoluciona desde un plano privado a uno público, y cómo sus poemas funcionan como metonimias del pueblo irlandés.

Nuestra tesis comienza apuntando datos biográfico que ayudan a enmarcar a nuestro autor en una época y en un contexto que son claves en el desarrollo de la Irlanda del siglo $\mathrm{XX}$, y sin los cuales nos sería difícil acercarnos a su poesía. 
Clarke vivió los acontecimientos sociales, políticos y culturales más significativos de toda la historia de la Irlanda moderna y contemporánea: el resurgimiento de una literatura propia, la independencia de Inglaterra, y la modernización de un país rayano en la miseria y el analfabetismo. Además de conocer y tratar con los escritores más distinguidos de la época - George Russel, F.R. Higgins, Joseph Campbell, Seamus O'Sullivan, James Stephens,...., tuvo la suerte de relacionarse con los dos escritores más emblemáticos de toda la historia literaria irlandesa: Yeats, de cuya sombra nunca pudo librarse, y Joyce, cuya obra guió no sólo los pasos de Clarke sino los de muchos otros escritores irlandeses.

Dos son las funciones de este capítulo biográfico: una, la de situar a nuestro autor en su contexto; la otra, y más importante en el caso de Clarke, la de arrojar luz sobre su obra. Como veremos a lo largo de la tesis, una de las características del estilo poético de Clarke es su dificultad, unas veces debida a su densa concentración de imágenes, y otras a su marcado carácter local. Por tanto, consideramos importante el papel que va a jugar el lector a la hora de extraer significados de los versos de nuestro poeta. El lector de Clarke ha de ser un lector que conozca la geografía, la historia y la cultura de Irlanda y de sus ciudades, especialmente Dublín, como los avatares de la propia vida del poeta. Aunque no es nuestra intención ceñirnos rigurosamente a las teorías de los críticos de la recepción como Fish, Iser o Jauss, hemos tenido en cuenta la definición que de un lector informado ofrece Stanley Fish: 
The informed reader is someone who (1) is a competent speaker of the language out of which the text is built up; (2) is in full possession of "the semantic knowledge that a mature ... listener brings to his task of comprehension," including the knowledge (that is, the experience, both as a producer and comprehender) of lexical sets, collocation probabilities, idioms, professional and other dialects, and so on; and (3) has literary competence. That is, he is sufficiently experienced as a reader to have internalized the properties of literary discourses" (Is There a Text in this Class 48 ).

De la oscuridad de la poesía de Clarke $^{7}$ se ha quejado, entre otros, Roscelli, que mantiene que "[they] are so complex in meaning, so concentrated in form, so crammed with personal and parochial allusions, as to tax the strength of even the most resolute reader" (56). Y en cuanto a su carácter local, sí es verdad que una parte de la crítica ha observado una cierta carencia de universalidad en su obra, y también es verdad que algunos de sus poemas no trascienden más allá de su propio contexto; sin embargo, muchos otros sí, y son precisamente éstos los que hacen que Clarke no sea un poeta más de segunda fila, sino un poeta cuya talla literaria ha de situarse a la misma altura que la de Kavanagh, Montague, Kinsella o, incluso, Seamus Heaney.

En nuestra opinión, etiquetar a Clarke como un poeta puramente provinciano es perderse gran parte de lo que tiene que ofrecer. El verdadero éxito de su poesía radica en expresar "accurately the Catholic and Gaelic dimensions of the Irish

\footnotetext{
${ }^{7}$ Agustine Martin comenta la dificultad de algunos poems de Clarke: "Indeed so minutely does he at times take the issue with the events and values which surround him that some of the occasional satires are virtually incomprehensible to foreigners" ("Rediscovery" 424).
} 
sensibility and in describing the political, social, and religious realities of life in modern Ireland" (Schirmer, PAC 5). Convendría, quizá, acordarse de la distinción que hacía Patrick Kavanagh entre parroquianismo y provincianismo ${ }^{8}$ : la mente provinciana sólo se fija en lo que ocurre o se dice en la capital, mientras que la mente parroquiana no duda en ningún momento de la validez artística y social de su parroquia. Es decir: "Parochialism is universal; it deals with the fundamentals". Clarke fue un poeta profundamente preocupado por los aspectos fundamentales de la existencia humana. Lo político, lo social, lo religioso son sin duda asuntos de la "parroquia", existentes en mayor o menor medida en todas las sociedades occidentales. En el fondo, la poesía de Clarke siempre celebra los valores inherentes en el ser humano, y sus versos se obstinan en exigir el derecho del individuo a la libertad moral, intelectual y espiritual.

En el segundo capítulo, analizamos Pligrimage and Other Poems, poemario que se publicó en $1929^{10}$, y que aborda, mediante máscaras y correlatos históricos, el conflicto privado entre la religión y el individuo en las dos vertientes de la carne y el espíritu, y de Catolicismo y Protestantismo

\footnotetext{
"Tengamos en cuenta que el término "parroquianismo" tiene normalmente un significado negativo. Sin embargo, Patrick Kavanagh en 1952 lo usó en sentido positivo, y lo distinguió del término "provincianismo". Esta distinción "chocó frontalmente con los ideales del resurgimiento celta (Celtic Revival), que consideraban a Irlanda como una entidad espiritual heredera de un pasado heroico. Kavanagh [...] buscaba la dimensión estética del momento presente en un contexto cotidiano" (Hurtley et al. 253).

${ }^{9}$ Citado en Schirmer, PAC 5.

${ }^{10}$ Hemos dejado a un lado los cuatro poemas épicos que escribió en su juventud porque en ellos se dedica Clarke a recrear las sagas mitológicas celtas, y no aborda el tema del conflicto de la forma objetiva con que lo hace en los poemarios y poemas que analizamos en esta tesis. Además, un estudio crítico de las sagas irlandesas conduciría a la elaboración de otra tesis, igualmente interesante, pero diferente de la nuestra.
} 
En el capítulo III, Night and Morning expone la otra parte del conflicto privado - el enfrentamiento entre la razón y la fe - y nos presenta a Martha Blake, la única persona en todo el poemario que se siente a gusto dentro del seno de la Iglesia Católica.

Si en Pilgrimage y Night and Morning, Clarke acomete el conflicto entre la religión y el individuo, a partir de 1955 traslada el conflicto a un plano público. En el capítulo cuarto analizamos poemas que escribió a partir de este año, y en los que se dedica a atacar a los principales causantes del conflicto expuesto en los poemarios anteriores: la Iglesia Católica irlandesa y el Estado. El recurso estilístico que utilizará para formalizar sus ataques es la sátira.-

Mnemosyne Lay in Dust, poemario protagonista del capítulo V, se hace a su vez eco de uno de los problemas endémicos de la sociedad irlandesa que no debemos obviar: la salud mental. Las enfermedades mentales en Irlanda han sido un tema sobre el que no se ha hablado demasiado. En la época de Clarke, esta reticencia se imponía a las víctimas y a sus familiares por igual (cf. Maxton 3). Hacia 1957, las autoridades irlandesas se empezaron a dar cuenta del problema, sobre todo al ver cómo crecía el número de personas mentalmente enfermas. Una década más tarde, aproximadamente cuando se publicó el poema de Clarke,

A government report indicated that mental illness might be more prevalent in Ireland than in any other country and that the rate of beds provided for the mentally ill 'appears to be the highest in the world'. At any one time, it was reckoned, one in every seventy people in the 
country over the age of twenty-four was in a mental hospital ${ }^{11}$. (Lyons 665)

No olvidemos tampoco que la locura ha ocupado un lugar importante en la literatura irlandesa. De la mitología celta nos ha llegado la historia de un rey del siglo VII, Sweeney ${ }^{12}$, que se enfrentó a la Iglesia y al que le echaron una maldición para que se volviera loco. Después de siete años recupera la lucidez y la memoria, pero una bruja le dijo: "For God's sake, leap for us now one of the leaps you used to leap when you were mad"13, y Sweeney le hizo caso y continuó inmerso en su locura sin poder deshacerse de la bruja, que lo acompañaba a donde quiera que fuera. Desde el siglo XVIII, además, la imaginación irlandesa ha mostrado una gran fascinación por la locura, el horror, y lo fantástico, y como apunta Smyth, "Like madness, then, literature [...] serves as a reminder of the contingent nature of reality" (54).

A la hora de realizar nuestro estudio sobre la obra de Clarke, hemos seguido un orden cronológico, excepto en el capítulo sobre la sátira, en el que hemos supeditado la cronología de los poemas a su temática. La metodología a la hora de analizar los poemas ha tenido un carácter ecléctico, y cuando nos hemos adherido a

\footnotetext{
"Lyons también apunta las causas de que haya tal número de enfermos mentales en Irlanda: “...the large number of elderly people in the population, the low marriage rate, the burden on some women of bringing up large families in adverse conditions, alcoholism, inbreeding in the remoter parts of the country, the pressures of rural isolation, and, above all perhaps, the selective effects of the emigration" (665).

12 También conocido como Suibhne, hijo de Colman Cuar. La historia se conoce con el nombre de The Frenzy of Suibhne, que a su vez coincide con el título de un poema de Clarke, "The Frenzy of Suibhne", perteneciente a su poemario The Cattledrive in Connaught (1925) y con el título de una de sus obras, "The Frenzy of Suibhne: A Lyrical Play", que no llegó a publicar y que solo existe en forma de manuscrito.

${ }^{13}$ Citado en Tapping, $A C 10$.
} 
alguna corriente teórica, la hemos usado en pequeñas dosis y donde convenía. Asimismo, hemos contrastado hechos históricos desde dos puntos de vista diferentes: el histórico y el poético. Para los Neohistoricistas, "el texto histórico no es un elemento auxiliar del literario, que ayude a leer e interpretar la obra estética, sino que este texto literario adquiere la misma dimensión que el histórico" (Galván 29). Nosotros, sin embargo, creemos que la historia sí complementa a la literatura, y en nuestro caso nos ha servido para comprender mejor los poemas de Clarke. Uno de los objetivos de la literatura en general es el de mostrar al lector las distintas idiosincrasias de un pueblo o de una sociedad. Recordemos las palabras de Barbara Tuchman: "What the poets [do is] to convey the feeling of an episode or a moment of history as they sensed it. The historian's task is rather to tell what happened within the discipline of the facts" (646). No obstante, no creemos en la supuesta objetividad del texto histórico, por lo que queda en manos del lector la tarea de interpretar y valorar lo que tanto el historiador como el poeta o novelista dejaron escrito para la posteridad.

La obra poética de Clarke es realmente extensa, pero, como hemos indicado líneas atrás, sólo nos hemos centrado en aquellos poemas en los que la idea de conflicto aparece como eje principal. Así, hemos creído conveniente añadir un apéndice al principio de esta tesis en el que enumeramos todos los poemas analizados en el texto y donde señalamos su procedencia y fecha de publicación. 
En cuanto a los criterios de anotación bibliográfica, hemos seguido el sistema de documentación de la Modern Language Association (MLA) ${ }^{14}$. Incluimos al principio una lista de aquellas obras que aparecen citadas por medio de sus iniciales. Las citas de los poemas de Clarke provienen todas de Collected Poems (1974), excepto las referencias a Mnemosyne Lay in Dust, que provienen de la edición original.

${ }^{14}$ En el sistema de documentación de la MLA, "a citation contains only enough information to enable readers to find the source in the works-cited list" (Gibaldi 195). 



\section{ABREVIATURAS}

Clarke, Austin:

A Penny in the Clouds

PIC

Poetry in Modern Ireland

$P I M$

The Celtic Twilight and the Nineties

TCTN

Twice Round the Black Church

TRBC

Collected Poems (1974)

TCP

The Collected Poems (1936)

$C P$

Corcoran, Neil

After Yeats and Joyce

AYAJ

Garrat, Robert F.

"Austin Clarke in Transition"

$A C$

Modern Irish Poetry

$M I P$

Halpern, Susan

Austin Clarke. His Life and Works

$A C$

Harmon, Maurice

Austin Clarke: A Critical Introduction

$A C$

Johnston, Dillon

Irish Poetry After Joyce

IPAJ

Joyce, James

Critical Writings

$C W$

Kennelly, Brendan

The Penguin Book of Irish Verse

PBIV

Mercier, Vivian

The Irish Comic Tradition

$I C T$

Schirmer, Gregory A.

The Poetry of Austin Clarke

Tapping, Craig G.

Austin Clarke. A Study of His Writings 
I. EL HOMBRE, EL ESCRITOR Y LA TRADICIÓN 


\section{I.1 Austin Clarke: apunte biográfico y bibliográfico.}

Hacia principios de los años noventa del siglo diecinueve, escritores como W. B. Yeats, Lady Gregory, Douglas Hyde, George Russell y George Moore, entre otros, se embarcaron en un movimiento cultural que se llamó Resurgimiento Literario Irlandés (Irish Literary Revival, o Irish Literary Renaissance'), y que "pretendió impulsar las cualidades culturales y espirituales que se tomaban como representativas de la identidad nacional" (Hurtley et al. 156). Basándose en trabajos literarios anteriores, que comprendían lo que Harmon llama "the matter of Ireland" ( $A C$ 12), es decir, las sagas mitológicas, la poesía, la historia y el folclore, estos escritores intentaron revitalizar la literatura de Irlanda recurriendo a motivos de la Irlanda celta y medieval, impregnándola de un fuerte carácter romántico. El punto de partida sería la publicación en 1879 de History of Ireland -Heroic Period, obra de Standish O'Grady ${ }^{2}$, que ofrece un retrato del periodo celta a través de la "biografía" de Cuchulainn³. Junto con O'Grady, aparecen también George Si-

\footnotetext{
1 .Término que alude al ambiente de ensoñación y romanticiśmo difuminado característico de los escritos de los autores irlandeses del Celtic Revival hacia finales del siglo XIX y principios del XX. Todos ellos buscaban dotar a sus obras de ciertas cualidades supuestamente nacionales, que las distinguieran de los textos de los autores irlandeses. De ahí el cultivo de la imagen de un pasado gaélico heroico, poblado de figuras míticas y legendarias, por un lado, y la creación de un estilo literario, por otro, en el que juega un papel importante el hiberno-English" (Hurtley et al 50).

Asimismo, este movimiento literario coincidió con al apogeo romántico del Celtic Revival, que comenzó aproximadamente hacia 1780 y, "como término crítico, coincide en gran medida con el de Celtic Twilight" (Hurtley et al 156).

${ }^{2}$ Standish James O'Grady (1846-1928), a quien se le llamó el padre del Resurgimiento Literario Irlandés, fue periodista, novelista e historiador. Estudió en Trinity College (cf. Kenny 91).

${ }^{3}$ Cú Chulainn / Cuchulainn era un héroe de la mitología celta....[Es] el epítome del espíritu heroico en la literatura irlandesa, y las narraciones y leyendas relacionadas con su figura constituyen una parte esencial de la imaginación popular. Fue objeto de considerable atención durante el resurgimiento celta (Celtic Revivial), sobre todo por parte de Standish O'Grady, Lady Gregory y W.B. Yeats" (Hurley et al 68).
} 
gerson como traductor y Douglas Hyde como traductor e historiador, que fueron en gran medida los responsables de acercar el espíritu y la forma de la literatura bárdica a autores que desconocían el pasado celta debido, principalmente, a su falta de conocimiento del gaélico.

Douglas Hyde, junto con Eoin MacNeill y ocho personas más, creó en 1893 la Liga Gaélica (Gaelic League), cuyo objetivo, según el propio Hyde, apuntaba a "de-Anglicise Ireland by refusing to imitate the English in their language, literature, and games”4. En los mismos años se creó la Asociación Atlética Gaélica (Gaelic Athletic Association), cuyos miembros sólo practicaban deportes genuinamente irlandeses. El objetivo de estas asociaciones era el de dotar a Irlanda de una identidad cultural que la diferenciase de Inglaterra. Su razón de ser, así como sus temas, logró sobrevivir hasta bien entrados los años treinta, aunque una década antes estos movimientos de marcado carácter celta -incluido el Resurgimiento Literario Irlandés - habían perdido todo su sentido porque el uso continuado de los mismos temas los había desgastado, y de la frescura de la que habían gozado al principio no quedaba apenas nada. Cuando estalló la huelga general de trabajadores de $1913^{5}$, escritores como W. B. Yeats, George Russell, y James Stephens, entre otros, habían lanzado ya en sus escritos a la prensa un mensaje claro: "[the]

\footnotetext{
${ }^{4}$ Citado en Harmon, AC 12 (cf. Hurtley et al 118-19).

${ }^{5}$ En estos mismos años, un grupo de socialistas liderados por James Connolly y Jim Larkin, que habían organizado el Sindicato General de Trabajadores y de Transporte Irlandés, fueron los responsables de una Huelga General que llevó a la calle a unos 20.000 trabajadores (cf. Hurtley et al 189 . 90; Peter Collins 302-303.
} 
romantic Ireland was 'dead and gone and with O'Leary in the grave" (Martin, "Clarke a Life" 66).

Una vez reivindicada la identidad cultural, era obvio reclamar también una identidad política, proceso que resultaría largo, difícil y sangriento. Así, aparecieron dos grupos explícitamente políticos: Sinn Fein y la Hermandad Republicana Irlandesa (Irish Republican Brotherhood), predecesora del IRA. El primer grupo buscaba establecer una monarquía dual de forma pasiva; el segundo aspiraba por la vía de la insurrección armada a la República Irlandesa, y de él formaron parte intelectuales como Padraic Pearse y Thomas MacDonagh. Al mismo tiempo entraba en activo un pequeño grupo de socialistas dirigidos por Jim Larkin y James Connolly, protagonistas de la huelga general de trabajadores de 1913. Poco a poco, durante los años adolescentes del nuevo siglo, los aires revolucionarios se fueron transformando en galernas que culminarían en la Insurrección de Pascua de 1916, que en sí misma no obtuvo el beneplácito de los irlandeses:

The Rising itself was not popular, but the execution of its leaders, including Padraic Pearse, Thomas MacDonagh, and Joseph Mary Plunkett, stirred the people to indignation, to the kind of defiance and selfassertion that had characterised Sinn Fein. (Harmon, $A C 13$ )

Las relaciones entre Irlanda e Inglaterra se fueron agriando, y su completo deterioro originó la Guerra de Independencia de 1919-21, cuyo final se selló con el trata-

\footnotetext{
${ }^{6}$ John O'Leary (1830-1907) estuvo asociado con el movimiento de la Joven Irlanda (Young Ireland movement). Encarcelado en 1848. Viajó a América. Se le volvió a encarcelar durante el periodo 1865-74, y cuando salió se exilió en París. Volvió a Irlanda en 1885 e influyó de gran manera en Yeats y otros escritores del Resurgimiento Literario Irlandés (The Oxford Companion to Irish History 409).
} 
do - Anglo-Irish Treaty - que conduciría al país a una cruenta guerra civil. Es, por tanto, este turbulento clima de las dos primeras décadas del siglo veinte el que Clarke respiraría mientras se adentraba en el panorama cultural irlandés y sus ambientes literarios.

De Austin Clarke no existe ninguna biografía. Solamente tenemos las escuetas "Notes Towards a Biography" de Maurice Harmon, y los dos volúmenes de memorias autobiográficas que escribió el propio Clarke: Twice Round the Black Church (1962) y A Penny in the Clouds (1968). Como ya mencionamos en la introducción, el papel del lector es crucial a la hora de entender la obra literaria en general, pero lo es si cabe aún más a la hora de comprender y analizar la obra de un poeta a quien se ha tildado en alguna ocasión de oscuro y difícil. Como quiera que los conflictos que forman el hilo conductor de esta tesis doctoral tienen en su mayor parte su origen en un entorno cercano al poeta, es necesario conocer siquiera por encima las vicisitudes de su vida para que nos ayuden a proyectar un poco de luz sobre los versos de su poesía.

Austin Clarke nació en la ciudad de Dublín en 1896 y murió en 1974, lo que le permitió no sólo vivir durante el periodo más revolucionario de la historia de Irlanda - las décadas de las que la Irlanda moderna emergería - sino codearse con los diversos movimientos culturales y sociales que modelaron la Irlanda del siglo XX: el Resurgimiento Literario y el crecimiento del fervor nacionalista que desembocó en la Insurrección de Pascua de 1916, la Guerra de Independencia contra Inglaterra, la posterior Guerra Civil, el advenimiento del Estado Libre, la depresión 
de los años treinta, la época oscura de la censura y del Catolicismo puritano, y a partir de los años sesenta, el desarrollo económico y el logro de una identidad política y cultural. Su padre, Augustine Clarke, era un modesto y tranquilo inspector del Departamento de Aguas de la ciudad que murió unos pocos meses antes de que Austin ingresara en el hospital psiquiátrico de St Patrick. Clarke nunca se sintió demasiado unido a su padre, e incluso se avergonzaba de su falta de cultura y de su bajo nivel de vida, especialmente cuando sus compañeros le preguntaban sobre su profesión:

'What is your father?' was a constant question both in the playground and in the class-room. So I dreaded the day when I would have to admit that mine was only an official in the Corporation. To make matters worse, my father, despite his rapid promotion, had never changed his easy-going ways and was not always as grammatical in his speech as I was. (TRBC 144)

En cambio, la relación con su madre, Ellen Patten Browne, fue muy diferente. Como veremos más adelante, la figura de la madre irlandesa jugaría un papel importante en la configuración del carácter de Irlanda, al ser ella la encargada de establecer un lazo de unión entre la Iglesia Católica y la familia. En el hogar de Clarke, la situación no habría de ser diferente. En sus memorias recuerda el opresivo clima de religiosidad que se vivía en casa - “...even our family prayers became an ordeal which grew worse every year" (TRBC 10) - y la obligación de ir a confesarse cada sábado - "There was a strict rule at home that I must go to Confession every Saturday in order to receive Holy Communion next morning" (TRBC 
132). Pero a pesar del puritanismo de su madre, Clarke admite su preferencia por la sangre materna antes que por la paterna:

In that moment, I had realized for the first time our common blood and was aware of the many dead about whom I knew so little. I forgot how much I had raged secretly against her when I was growing up, our incessant quarrels over religion, my bitterness when she seized and burned those heretical books of mine, most of them in cheap reprints which I had to buy all over gain. I knew, then, that I preferred that obstinacy of the Brownes, which was her pride, to the generosity and easy-going of my father. Her coldness and reserve would at last be mine also, and I saw clearly that it was her determination which had saved us all from indigence in the Liberties of Dublin long before I was born. (TRBC, 7)

Asimismo, sus sentimientos hacia su madre se vieron envueltos en un complicado entramado emocional sobre la religión y el hecho de hacerse hombre. Su pubertad fue una etapa difícil en su vida, y estuvo constantemente acechada por un complejo de culpabilidad que le costó exorcizar: "Ignorant and confused by physical development and the change in scrotal sensation, I became convinced that the Devil entirely possessed me and, startled by the first bristles below, I seized a scissors and in an agony of alarm shore myself" (TRBC 135). De igual modo, todo lo relacionado con el sexo o incluso con la procreación tenía para él un tinte pecaminoso prácticamente inadmisible. Así, por ejemplo, durante años "[he] refused absolutely to accept the uro-genital design, regarding it as a proposition of the Devil" (TRBC 164), y la concepción tenía lugar sin apenas contacto físico, "I was certain, 
therefore, that conception took place not in a gross way but ethereally by the gentle touch of the male and female paps" (TRBC 164).

La educación escolar del joven Clarke fue variada. Aparte de la Escuela nacional y la Escuela de los Hermanos Cristianos de Dublín, y un colegio de Jesuitas en Limerick, Clarke estudió en el colegio jesuita de Belvedere, el mismo al que había asistido James Joyce unos años antes. Después fue a University College Dublin, donde encontró el ambiente adecuado para desarrollar su carrera literaria: Yeats, Douglas Hyde, AE, y George Moore, entre otros, avivarían su disposición por la literatura del Resurgimiento Literario Irlandés. Allí, asiste a las clases de Douglas Hyde ${ }^{7}$ a la sazón profesor de Irlandés Moderno, cuyas clases supusieron toda una revelación para él:

On the morning of our first term, he [Hyde] spoke of the aims and ideals of the language revival; we were all equal, all united in the Gaelic movement.... Those plain words changed me in a few seconds. The hands of our lost despised centuries were laid on me. (TRBC 167)

Las enseñanzas de Hyde le condujeron a otro profesor de la misma universidad, Thomas MacDonagh, cuyos estudios sobre la métrica gaélica influirían de forma concluyente en su poesía; sin embargo, la trágica muerte de MacDonagh en la Insurrección de Pascua truncó los planes de Clarke. Abandonó la tesina que iba a realizar bajo la supervisión de MacDonagh sobre la influencia del laúd en la poesía

\footnotetext{
7 “Escritor, traductor, ideólogo nacionalista y político: primer Presidente de Irlanda. [...] Desde 1909 hasta 1932 ocupó la cátedra de Irlandés Moderno en UCD. Ejerció de senador del Estado Libre (Free State) entre 1925 y 1926 y de nuevo en 1937. En 1938 fue nombrado Presidente de Irlanda bajo la nueva Constitución. [...] Ocupó el cargo hasta 1945" (Hurtley et al 149).
} 
de la época Tudor, y escribió una sobre John Ford ${ }^{8}$. Después de obtener su M.A., se dio cuenta de la futilidad de su nuevo título y decidió desempolvar el violín, que tiempo atrás había arrinconado en su casa, e intentó conseguir un puesto en el New Ross Cinema de Dublín, pero todo ello fue en vano. Poco después fue admitido para el puesto de Profesor Ayudante en el Departamento de Inglés en UCD, posición que había ocupado anteriormente su profesor Thomas MacDonagh.

Por la misma época, Clarke trabó amistad con F.R. Higgins, con quien solía hablar de poesía, pasear por las calles de Dublín y charlar en pequeños cafés italianos:

We were both eighteen, but I was owed by his knowledge of the 'Nineties, the Celtic Twilight, Symbolism, and Maeterlinck for at that time Yeats was still known as the Celtic Maeterlinck. (PIC 14)

Penny in the Clouds, el segundo volumen de memorias de Clarke, abunda en anécdotas y recuerdos con Higgins, a quien debe su interés por la época medieval irlandesa: "To that talk behind a wooden partition in a plain café, I owed my later interest in the neglected Celtic-Romanesque centuries" (PIC 17). También rememora su amistad con Stephen McKenna, "a legendary figure in the literary circles of Dublin" (PIC 20), a quien consideraba como su padre literario. Lo recuerda como una persona enfermiza, alta, de pelo negro y de movimientos lánguidos, cuyo humor variaba imprevisiblemente. Cuando Clarke escribió su primer poema épico,

\footnotetext{
${ }^{8}$ Dramaturgo inglés (1586 -c.1655) cuyo estilo se caracterizaba por su espontaneidad lírica, un patetismo suave, una intensa descripción del alma en pecado, y un sutil análisis introspectivo de la mujer. Para unos, John Ford encarna la decadencia; para otros, es el profeta de un nuevo mundo. Entre sus obras figuran, Fame's Memorial (1606), 'Tis Pity She's a Whore (1633), The Broken Heart (1633),
} 
The Vengeance of Fionn (1917), se lo enseñó a McKenna; éste le sugirió que se lo mostrara a Ernest Boyd, considerado por entonces el principal crítico literario, quien a su vez se lo recomendó a George Russell (AE). A éste le gustó el poema y ayudó a Clarke a publicarlo. Según Agustin Martin, en este primer poema, "One can hear something of its Irish mode in the lapsing rhythms its interlacing assonances to say nothing of its feel of genuine Irish landscape and weather" ("Clarke a Life" 67). A partir de este poema se le empezó a considerar como una nueva voz en la poesía irlandesa, y se fue introduciendo en el círculo donde se encontraban muchas de las figuras literarias asociadas con el Resurgimiento Literario Irlandés.

Las primeras lecturas de los poemas de los poetas de este movimiento literario le resultaron infructuosas y poco menos que ininteligibles, como él mismo afirma en sus memorias:

When I first discovered for myself the poetry of the Celtic Twilight period [...], and read the poems of that period, much was quite incomprehensible to me. [...] It was all quite unlike English poetry and quite unlike that Gaelic poetry which Dr. Douglas Hyde declaimed for us in class [...]. When I had made, however, the Grand Tour of English literature, the difficulties were gone. It was pleasant to escape for a while from the law and order of English poetry into that shadowy world of subdued speech and nuance. (Clarke, PMI 16)

Pero Clarke había empezado a asistir a las tertulias que AE, su mentor espiritual, organizaba los domingos por la tarde, y en una ocasión, después de que todos los

The Chronicle History of Perkin Warbeck (1634), y The Witch of Edmonton (c.1622, publicada en 1658) (cf. William Bradley Otis et al. 246-47). 
invitados se hubieran ido a casa, AE le leyó unos párrafos de History of Ireland de Standish O'Grady y de su propio poemario Flight of the Eagle (1899), en el que Clarke "was aware for the first time of an older religion than the one I had known from childhood" (Clarke, PIC 51). Así, empezó a admirar los sutiles ritmos de la poesía del Resurgimiento, que le impulsaron a imitar ese "shadowy world of subdued speech and nuance" (Clarke, $P M I$ 16), y que le abrieron los ojos al mundo de las sagas y mitología celtas.

Clarke no pertenecía al mismo grupo de poetas que fundó y consolidó las pautas del Resurgimiento Literario Irlandés, sino a una segunda generación de escritores, entre los que se encontraban el ya mencionado F. R. Higgins, Liam O’Flaherty y Padraic Column, entre otros. Éstos redescubrieron el mismo material celta, pero con dos importantes diferencias respecto a los fundadores. En primer lugar, tenían un conocimiento del idioma gaélico del que había carecido la primera generación de poetas, y, en segundo, éstos podían acceder no sólo a las misma fuentes que sus antecesores sino también a la literatura de los escritores del Resurgimiento. Esto lo comenta el propio Clarke en sus memorias:

The discovery of our own mythology and epic stories by the poets of the Irish Literary Revival excited my imagination and I cycled with delight to many places associated with legend and enchantments - from the Glen of the Madmen in County Kerry to the Twelve Pins of Connemara and the Poisoned Glen in Donegal. (PIC 84).

No obstante, nuestro poeta se diferenciaba de sus compañeros generacionales en que se fijó menos en la tradición baladística gaélica, y puso toda su atención 
en el sistema métrico de la poesía de los Bardos gaélicos, que adaptó a su propia poesía. Temáticamente se fue alejando progresivamente de la mitología y las sagas celtas para acercarse a la Irlanda contemporánea vía la Irlanda medieval. A su vez, "[Clarke] became ... more and more a nonconformist and individualist, at war with much of what was around him, and even with much that lay inside him" (Fallon 113). Su actitud rebelde hacia la vida provocó tensiones y conflictos, mayoritariamente de tipo religioso y sexual, que además de quedar reflejados en mucha de su poesía, se convertirían en un lugar común en la literatura irlandesa.

El origen de estas tensiones hay que buscarlo en la infancia de Clarke, porque es en ella donde aparece el clima religioso y político que modelaría la conducta y la personalidad del poeta. Twice Round the Black Church, libro de memorias que toma su título del nombre de la iglesia protestante St. Mary's', está estructurado en una serie de oposiciones, tales como madre y padre, campo y ciudad, religión y naturaleza, presente y pasado, y en todas ellas, el denominador común es la religión: una madre excesivamente religiosa, una ciudad extremadamente católica. y un pasado histórico constantemente dominado por tensiones religiosas. No es de extrañar, por tanto, que la crisis mental que sufrió Clarke cuando tenía veintitrés años tuviera su origen en la angustia existencial que le provocaron los dogmas religiosos que le habían inculcado en su infancia.

\footnotetext{
${ }^{9}$ Esta iglesia se encontraba en el barrio donde Clarke pasó su infancia, y era símbolo de terror para los niños católicos:

"After school the little boys and girls from Paradise Lane, which was at the back of our street, scampered around the Black Church. But at night the shadowy gas-lit place was silent and deserted, except for the echoing footsteps of a passer-by or the rumble of a cab. As children, we were told that anyone who ran round the church three times after dark would meet the Devil himself on the third round, but none of us had the courage to test the legend" (Clarke, TRBC 22).
} 
Un hecho que marcaría su vida fue el incidente del confesonario en el que un sacerdote le obligó a admitir que había pecado contra el sexto mandamiento, sin que supiera bien lo que el inquisidor eclesiástico le estaba preguntando: “At last, in fear and desperation, I admitted to the unknown sin" (TRBC 130). De nuevo, durante su adolescencia, Clarke relata otra confesión en la que el sacerdote le pregunta, "Did you let your nature flow?" (TRBC 137), y que muestra nuevamente la obsesión que los sacerdotes, y por extensión la Iglesia Católica, tenían con el sexo. Para Agustin Martin, su infancia "was a miserable childhood and its terrors never ceased to haunt the dreams and nightmares of his adult existence" ("Clarke a Life" 68). Sin embargo, no todos los autores están de acuerdo con el hecho de que Clarke tuviera una infancia extraordinariamente difícil. Para Loftus, por ejemplo, "his childhood seems to have been no more traumatic than that of any middle-class child" (265). Nosotros inclinamos la balanza a favor de Loftus, pero estamos convencidos de que los dogmas católicos, sumados a la turbulencia histórica de la época, tiñeron la extremada sensibilidad del poeta de un malestar que no cejaría de rezumar a lo largo de su obra literaria.

A medida que Clarke fue creciendo, el puritanismo de su madre, la educación religiosa de los jesuitas, y la imposibilidad de mediar entre las exigencias de su cuerpo adolescente y las restricciones que su conciencia religiosa le imponía, le llevaron a la crisis mental que sufrió en 1919. Ante este panorama tan desolador, es comprensible que la verdadera razón de su rencor hacia la Iglesia Católica provenga no ya de los traumas que pudo o no sufrir durante su infancia, sino de todas 
esas circunstancias que se fueron acumulando hasta llegar a una situación insostenible y que formaron distintos frentes conflictivos que Clarke fue dirimiendo a lo largo de toda su obra poética. Su aversión por la política deriva de la connivencia del Estado con la Iglesia Católica, relación que sería asimismo objeto de una suave, pero afilada, sátira.

El año 1917 resultaría excelente en la vida del joven Clarke: publicó su primer poema épico - The Vengeance of Fionn-, consiguió su M.A., y ocupó la plaza de MacDonagh en UCD. Después de la Insurrección de Pascua de 1916, Thomas MacDonagh, profesor y director de la tesina de licenciatura de Clarke, fue ejecutado por su participación en ella. Su muerte fue especialmente traumática para Clarke, ya que entre profesor y discípulo se había establecido una amistad que truncó la represión británica; además, MacDonagh había ayudado y animado a nuestro joven poeta a escribir poesía. A raíz de su ejecución, su plaza en la universidad quedó vacante, y la ocupó Austin Clarke como profesor ayudante en 1917. Además de la seguridad financiera que le proporcionaba su plaza de profesor, Clarke gozaba de un reconocimiento académico y crítico que le ayudó a introducirse en un círculo de poetas entre los que se encontraban AE, Stephens, F R Higgins, Ernest Boyd, Osborne Bergin, Sarah Purser, Monk Gibbon, y otros. Pero a pesar de este aparente éxito, la conciencia de Clarke no se encontraba totalmente equilibrada. 
Poco después, Clarke se enamoró de Margaret ${ }^{10}$ (Geraldine Lia Cummings), novelista y poetisa, siete años mayor que él, con quien se casó civilmente el 31 de diciembre de 1920 , y cuyo matrimonio duró solamente una semana y quedó sin consumar, según el propio Clarke ${ }^{11}$. Previamente, en 1919, una profunda depresión había provocado en Clarke la crisis mental que hemos mencionado anteriormente y que lo mantuvo hospitalizado poco más de un año en el hospital psiquiátrico que fundó Swift, St Patrick’s Hospital. Su experiencia en el hospital debió ser extremadamente desagradable, ya que tardó treinta años en publicar un poema en el que describe su estancia y el tratamiento al que fue sometido. Cuando recibe el alta del hospital, se encuentra con que su país está sumido en la Guerra de Independencia contra Inglaterra. Decide irse a recorrer en bicicleta el oeste gaélico irlandés - de Kerry a Connemara y después a Donegal -, viaje que le proporcionaría numerosas anécdotas que quedan recogidas en A Penny in the Clouds. Al volver se encuentra con un panorama poco menos que desolador. A la inestabilidad política del país hay que añadir la suya propia: el fracaso de su matrimonio, y la no renovación de su contrato de trabajo en la universidad, debido básicamente al hecho de haberse casado fuera del amparo de la Iglesia Católica, y, quizás también, al contenido de su nuevo poema épico, Fires of Baal, sobre un mito del Antiguo Testamento y con abiertas manifestaciones sexuales que no complacieron a sus ya de por sí descon-

\footnotetext{
${ }^{10}$ Margaret Lyster era el nombre literario de Geraldine (Lia) Cummings. Se casaron el 31 de Diciembre de 1920 en Dublín, y F. R. Higgins fue uno de los testigos. En 1926, Clarke interpuso una demanda para divorciarse, pero no tuvo éxito (cf. Maxton, 251; Austin Clarke, TRBC 87-88; Austin Clarke, PIC 43-44, 115; Mary Thompson, "Austin Clarke" 110).

"Clarke dice en sus memorias: "Unfortunately my marriage proved a failure for it was only a mariage in name and lasted less than a fortnight" (TRBC 88).
} 
tentos jefes en la Universidad ${ }^{12}$. Este mismo año sería también testigo de su tercer poema épico, The Sword of the West, que se publicaría poco antes del estallido de la Guerra Civil.

En 1922 decide exiliarse en Inglaterra: "I could not blame them [the University staff] for I had committed too grave an offence and the penalty, in effect, was banishment" (TRBC 88). Llega a Londres con cartas de recomendación para escritores como Alice Meynell, G.K. Chesterton y otros, pero su vida en el exilio no estaba dispuesta a sonreírle, y se vio obligado a sobrevivir en un entorno de pobreza y soledad y a ganarle un salario a la vida mediante la crítica de libros. Vive de pensión en varios barrios londinenses, Chelsea, Vauxhall Bridge Road y Bloomsbury, y como manifiestan sus memorias, las primeras semanas en Londres no fueron en absoluto agradables: "In the horrible gloom and fogginess of those first weeks there, as I wandered through the crowds, I saw all distortedly as if I were a French or Belgian writer of the "Nineties"' (TRBC 88). Consigue trabajar como crítico literario para el rotativo Daily News, pero la soledad le obliga a reconsiderar su situación y "after many restless hours of broken sleep, I explained to my landlady that I had been recalled unexpectedly to Ireland" (TRBC 92). Vuelve a Dublín pero, a pesar de que su madre se ofrece para ayudarle económicamente, Clarke prefiere vivir lejos de su influencia. Al poco tiempo, la vida en Dublín no le acaba de sonreír y decide volver a Londres:

So, being restless and still disturbed by the failure of my secular marriage, I decided to go back to London. I did so with regret for, despite

${ }^{12}$ Cf. TRBC 86 . 
the emotional havoc of the Civil War and its immediate miseries, the Irish Free State was just beginning and hopes for a small independent literature with its own standards of criticism were astir. (TRBC 93)

Así, Clarke se encuentra de nuevo en Londres en 1923, pero pasa el invierno en París, donde hace una breve visita a James Joyce, de la cual sorprendentemente no hace mención alguna Richard Ellman, su biografo oficial. En A Penny in the Clouds, Clarke habla de su encuentro con Joyce ${ }^{13}$, pero aparte del interés de éste por la vida literaria dublinesa, el encuentro en sí no tuvo mayor trascendencia; sin embargo, la obra de James Joyce en Clarke sí la tuvo, como veremos más adelante. Su estancia en el exilio no duraría mucho, y se vio obligado a volver a Irlanda a causa de una fuerte depresión. En 1924 vuelve a viajar por el oeste de la Isla, esta vez por el condado de Clare, y descubre el mundo medieval que utilizaría para sus obras posteriores - ese mundo que él llamaría Celto-Romanesque. En 1925 publicó un cuarto poema épico, The Cattledrive in Connaught and Other Poems, que representaría su adiós a las sagas mitológicas celtas. Durante los años siguientes, seguiría instalado en Inglaterra, pero haría breves visitas a Irlanda hasta que en febrero de 1937 decide regresar y quedarse permanentemente en Dublín. Una vez aquí, Clarke, su mujer y sus hijos se fueron a vivir a Bridge House, que se encontraba en lo que en aquella época era el pequeño pueblo de Templeogue, en el condado de Dublín. La casa la había donado su madre a la Iglesia Católica, aunque dispuso que la habitara su hijo en usufructo, y sobre lo cual escribiría un poema irónico en 1957 llamado "Usufruct" (207), en el que amargamente se queja de

${ }^{13}$ Cf. PIC 95-96. 
haber sido reducido a la condición de inquilino de la propiedad de su propia familia:

This house cannot be handed down.

Before the scriven ink is brown,

Clergy will sell the lease of it. (1-3)

...

My mother wore no rural curch

Yet left her savings to the Church,

That she might aid me by-and-by. (11-13)

A principios de los años treinta, Clarke conoce a Nora, que sería su segunda esposa, y con quien se instala en una vieja casa en Hertsfordshire. Unos años antes, concretamente en 1929, había publicado Pilgrimage and Other Poems, poemario en el que recrea el mundo celta medieval. Aunque en los poemas épicos anteriores ya aparecía el obsesivo conflicto entre la carne y el espíritu, será en esta obra donde el conflicto tenga un escenario real y tangible, al contrario que en su poesía anterior, donde Clarke trabajaba con personajes mitológicos.

El principal conflicto de Pilgrimage - deseo sexual versus dogma religioso-, como veremos en el siguiente capítulo, se convierte en hilo conductor de su novela de 1932, The Bright Temptation. A ésta le seguirían otras dos - The Singing-Men at Cashel (1936) y The Sun Dances at Easter (1952)-, y todas ellas comparten el escenario medieval, los temas, y la lucha contra la censura de la época, que prohibió la publicación de las dos primeras novelas en suelo irlandés. El gobierno, en connivencia con la Iglesia, había establecido la censura en el país a través de la Ley de Censura de Publicaciones (Censorship of Publications Act) de 
$1929^{14}$. Era esencial que el gobierno protegiese la vida irlandesa de cualquier influencia externa impura, y que ayudase a crear una civilización irlandesa católica y pura. En febrero de 1930 se creó la Comisión para la Censura de Material Impreso (Censorship of Publications Board), integrada por cinco miembros del Ministerio de Justicia, y cuya misión era prohibir libros o revistas que la comisión considerara indecentes, o que alentaran a la delincuencia o al crimen, o que promocionaran el aborto o la anticoncepción. Esta comisión suprimió cerca de 1200 libros y 140 periódicos y revistas antes de 1940, lo que hizo que Robert Graves más tarde dijera, "The fiercest literary censorship this side of the Iron Curtain"15.

Una vez instalado en Dublín, Clarke vivirá hasta su muerte en Bridge House, Templeogue, en el condado de Dublín, con su mujer, y sus tres hijos, Donald, Aidan y Dardis. Es curioso que ni ella ni sus hijos aparezcan mencionados en sus memorias o en su obra: tan solo unas breves líneas en su poesía tardía prestan efímera atención a Nora ${ }^{16}$. En 1938 Clarke sufrió un nuevo colapso mental, debido seguramente a la negativa de su primera esposa a concederle el divorcio o anulación matrimonial, por lo que su actual matrimonio carecía de estatus legal. Esta crisis se vería reflejada en el poemario de 1938, Night and Morning, después de cuya publicación se sumiría en un silencio poético que duró hasta 1955. Se han

\footnotetext{
${ }^{14}$ Según Michael Adams (13), el movimiento independentista irlandés fue poco más que político; es decir, un movimiento que buscaba deshacerse del yugo británico, pero que no tenía una ideología claramente definida. Así, en los primeros años veinte, el Estado Libre siguió con el sistema de leyes británico, con solo unas pequeñas excepciones. En cuanto a la legislación que controlaba la literatura considerada obscena, no se hicieron cambios al respecto.

${ }^{13}$ Citado en Johnston, IPAJ 7.

16 No hay apenas información sobre ella. Maurice Harmon dice escuetamente: "Meets his future wife, Nora Walker, at Bulmer Hobson's house in Rathfarnham" ("Notes" 20). Asimismo, aparece brevemente en "Beyond the Pale" (289), poema de apreciación y amor por ella.
} 
apuntado varias razones por las que dejó de escribir poesía, y parece haberlas para todos los gustos: desde su desesperación al descubrir que Yeats no lo había incluido en The Oxford Book of Modern Poetry (1936), pasando por la irritación que al parecer le había provocado la popularidad de Kavanagh, hasta la idea de que sacó un nuevo volumen de poesía en 1955 para comprobar si su poesía seguía siendo válida ( $C f$. Frazier 53). Sin embargo, todas estas razones parecen carecer de una base sólida, y Frazier las echa por tierra argumentando que la antología de Yeats apareció en 1936, y que Clarke publicó Night and Morning en 1938, por lo que su exclusión no tuvo por qué afectarle, y si lo que necesitaba era el reconocimiento de su poesía, esto tampoco era necesario porque el poemario de 1938 fue el más aclamado de su carrera hasta ese año. Clarke, sigue comentando Frazier, "was neglected in the Forties and early Fifties because he stopped writing poetry; he did not stop writing because he was neglected" (53). Para Redshaw, en cambio, Clarke dejó de escribir poesía porque "he devoted much of his original energies to the first two of his Celtic Romanesque romances - The Bright Temptation (1923) and The Singing Men at Cashel (1936)" (107).

Aunque Clarke dejó de escribir poesía durante diecisiete años, su labor creativa no cesó: desde 1938 hasta 1955, Clarke escribió nueve obras dramáticas y su tercera novela, The Sun Dances at Easter (1952). Empezó a frecuentar los círculos literarios y teatrales de Dublín, y en 1938 fundó la Lyric Theatre Company, con objeto de revivir la tradición de obras de teatro en verso que Yeats había comenzado en el Abbey, y que parecía haber muerto con él. Su preocupación e inte- 
rés por esta forma teatral le llevó a crear la Dublin Verse Speaking Society, cuyo objetivo fundamental era el de formar a actores y locutores de radio para que fomentaran el recitado en verso. Hacia 1944, la compañía de teatro ya se había formado, y alquiló el Abbey para representar obras en verso los domingos por la noche. Las representaciones incluían obras de numerosos autores, tales como W. B. Yeats, George Fitzmaurice, Donagh MacDonagh, Padraic Colum, Gordon Bottomley y, por supuesto, algunas de Clarke como The Third Kiss, The Flame, o As The Crow Flies. En 1951, el Abbey Theatre se quemó, lo que puso fin a estas representaciones.

Antes de la muerte de Yeats, Clarke había escrito solamente tres dramas, que no se habían representado en el Abbey, y uno de ellos, Sister Eucharia, no se había representado nunca ${ }^{17}$. No obstante, se habían publicado en la revista The Dublin Magazine. A partir de 1939, Clarke escenificó cuatro obras más, "in which he has not only kept alive the tradition of verse drama in Ireland, but has enlarged it" (Mercier, "Verse Plays" 39). Esto lo confirma también McHugh, para quien Clarke es recordado

...chiefly $[\ldots]$ for the way in which, through the formation of the Dublin Verse-Speaking Society with Robert Farren in 1938 and of the Lyric Theatre Company in 1944, he kept poetic drama in Ireland alive, first on radio, then for two weekly seasons a year (1941-46) in the Peacock Theatre, and finally by special Sunday performances of

\footnotetext{
${ }^{17}$ Su primera obra, The Son of Learning, escrita probablemente en 1921, fue rechazada por el Abbey en 1927 y se representó en el Cambridge Festival Theatre en Octubre de este año. The Flame se representó en 1932 en School of Speech Training and Drama en Edimburgo.
} 
verse-plays in the Abbey Theatre from 1944 for almost a decade until that theatre burnt down in 1951. (52)

Las obras dramáticas de Clarke son de dos tipos: obras en clave de comedia, que fueron las que más éxito tuvieron y que se concibieron como entretenimiento, y obras más serias que exploran los efectos de las crisis de conciencia individuales. Aunque solamente escribió un total de dieciséis obras - nueve comedias, entre las que se encuentran las adaptaciones de Cervantes, The Student from Salamanca y The Silent Lover ${ }^{18}$, y siete obras serias más una adaptación de un relato corto de Nathaniel Hawthorn ${ }^{19}-$, Clarke las escribió a lo largo de toda su vida literaria. Su primera comedia, The Son of Learning la escribió en 1921, y la última, The Third Kiss, se publicó en 1976. Durante el periodo en que no escribió poesía, es decir, desde 1938 hasta 1955, publicó tres obras, Sister Eucharia (1938), The Kiss (1942) y The Second Kiss (1946).

Prácticamente, todas las obras dramáticas de Clarke se pueden tratar en términos religiosos - la ortodoxia católica contra la razón humana; en términos políticos - la autoridad del Estado contra la libertad individual; y en términos morales - el conformismo contra la rebeldía innata del hombre. Clarke aborda los mismos temas que en sus novelas o en su extensa obra poética, especialmente lo que el llama drama de la conciencia de Irlanda, tema unificador en toda su obra. El mis-

\footnotetext{
${ }^{18}$ Estas corresponden a La Cueva de Salamanca y a El Viejo Celoso respectivamente.

19 El relato de Hawthorn es "Young Goodman Brown", y la obra de Clarke, que se publicó en marzo de 1973, se llamó The Impuritans.
} 
mo Clarke dijo que quería escribir "for a "bolder stage" wherein "the drama of racial conscience' could be fully explored"20.

De igual forma que la vida en Inglaterra no le fue fácil, su retorno a Irlanda iba a ser duro y difícil, especialmente con una familia que alimentar. Solicitó ser director de Inglés en Trinity College, pero no lo consiguió. En 1932 ganó el premio nacional de poesía de Tailteann Games, y aparte de ser elegido miembro fundacional de la Irish Academy of Letters, fue también presidente de la delegación irlandesa de la organización internacional PEN (Poets, Essayists and Novelists) desde 1939 hasta 1942 y desde 1946 hasta 1948. Tuvo la suerte de estar siempre rodeado de gente que le apreciaba, tanto entre escritores como entre críticos. Consiguió, asimismo, trabajar para el rotativo The Irish Times como crítico literario, y también se las apañó para trabajar de forma regular en la radio irlandesa, Radio Éireann, donde tenía un programa de poesía en el que se hablaba de poemas que a su vez se comentaban y explicaban en directo:

For it brought to a national audience, or to all who would listen, a realisation that poetry was alive and well, was not something that belonged in schoolbooks, or in those more rarefied volumes read (if at all) by a privileged few. (MacReamoinn, "Poetry" 162)

Desafortunadamente, Clarke no era un buen locutor, y su programa semanal sobre poesía se hizo tedioso y repetitivo, al igual que su columna semanal en The Irish Times, que a veces era aburrida, pedagógica, quisquillosa e indefinida ( $c f$. Fallon,

\footnotetext{
${ }^{\curvearrowright}$ Citado en Tapping, $A C 92$.
} 
Age 116). Pero esto no es óbice para que sus dotes como crítico literario emergieran en los cientos de ensayos y columnas que escribió a lo largo de su vida.

Después del silencioso periodo poético que siguió a Night and Morning, Clarke emerge en la escena literaria con Ancient Lights $^{2 l}$ (1955), poemario que tuvo un excelente recibimiento y con el que comenzó la segunda etapa lírica del poeta. Este volumen lo criticó el joven poeta Donald Davie ${ }^{22}$, que trabajaba entonces en Trinity College Dublin, y a quien, a pesar de la oscuridad de algunos poemas, le llamó poderosamente la atención por su fuerza y originalidad. No en vano le pareció que este poemario "should be taken up into the tradition of English poetry wherever it is written" (58). El poemario estaba subtitulado, 'Poems and Satires, First Series', y le seguirían otros dos volúmenes en los que su componente principal sería la sátira, Too Great a Vine, poems and satires (1957) y The HorseEaters, poems and satires (1960), y que se imprimirían asimismo en Bridge Press. Pero estaba claro que publicar de forma limitada no llevaba a ninguna parte, y lo que necesitaba Clarke era un editor. Así, en 1961, Liam Miller, de Dolmen Press, publicó Later Poems ${ }^{23}$, y, en 1963, Flight to Africa, que devolvieron a Clarke a la escena poética de Dublín. Este último poemario se merece unas líneas porque, tomado en general, representa el esplendor poético de Clarke: "it represents his work at its best; it is his supreme accomplishment as a craftsman" (Halpern, $A C$ 92). Flight to Africa, además, despliega una mayor diversidad de temas. Incluye

\footnotetext{
${ }^{21}$ Fue publicado de forma privada en la imprenta del autor, Bridge Press.

${ }^{2}$ Cf. Davie Donald, "Spring Verse Choice" 57-58.

${ }^{23}$ A pesar de la oscuridad de los poemas de Clarke, Donald Davie, en su crítica a esta colección, dijo que era "the crown in Clarke's achievement" ("Insights and Epigrams" 246-47).
} 
cincuenta y nueve poemas de longitud variable, y está divido en tres partes que, temáticamente, no corresponde con las partes que Clarke asignó. Poemas autobiográficos, poemas sobre sucesos nacionales políticos, poemas de paisajes, y versiones de poemas tradicionales y del siglo dieciocho dan una excelente variedad temática al poemario. Clarke comenta en sus notas que todos los poemas excepto tres son el producto de un viaje que hizo a Grecia, concretamente al Monte Parnaso, y que patrocinó una universidad americana. Este viaje provocó un brote de creatividad que no desaprovechó:

Shortly after my return I experienced for ten weeks a continual, voluptuous state during which the various pieces arrived with such joyful ease that I suspect some to be Greek gifts. (Clarke, CP 553).

En estos años sesenta, Kavanagh, cuya producción poética había sido escasa durante los años cincuenta, tuvo un espectacular regreso con Come Dance with Kitty Stobling (1960) y Collected Poems (1964), y cuando Clarke publicó Mnemosyne Lay in Dust en 1966, Seamus Heaney publicó su primer volumen de poesía, Death of a Naturalist. La misma Dolmen Press sumaría a sus filas a poetas de la talla de Thomas Kinsella, John Montague y Brendan Kennelly. Esto demuestra que la vuelta de Clarke no sólo fue estupenda por su parte sino que estuvo acompañada de todo un renacimiento poético en el que él ocupaba un puesto de honor, y en el que Liam Miller destacó por su gran labor editorialista. Este mismo año 1966 
fue también el año en que un nutrido grupo de poetas y escritores homenajearon a Austin Clarke en honor de su septuagésimo cumpleaños ${ }^{24}$ :

When we consider the work of Austin Clarke, beginning with the early poems and moving through the plays, the poems of his maturity, we find an artist who was tardy in recognizing where his strength lay, ... There is a strange and wonderful synecdoche in these late poems, so that little things implicate big things, the Irish part stands for the human All. (Donogue, "One more brevity" 21).

Después de Mnemosyne Lay in Dust, Clarke continuaría escribiendo poesía hasta su muerte en 1974, fecha en que aparecería publicado Collected Poems. Las dos colecciones que siguieron a los vehementes versos de Mnemosyne -Oldfashioned Pilgrimage (1967) y The Echo at Coole and Other Poems (1968)-, serían volúmenes de transición entre su largo poema autobiográfico y A Sermon on Swift (1968), Orphide and Other Poems (1971) y Tiresias (1971), su última obra. Old-fashioned Pilgrimage contiene veintidós poemas, entre los cuales destacan poemas sobre sus viajes por Europa y América, sobre otros poetas, que ilustran el ecléctico gusto de Clarke -Edgar Allan Poe, Walt Whitman, Robert Frost, García Lorca, etc. - , y sobre mujeres, en los que Clarke demuestra una vez más su interés por la condición de la mujer en una Irlanda sometida al poder de la Iglesia Católica y del gobierno. "The Pill" y "The Redemptorist" son dos ejemplos que comentaremos en el capítulo IV, y que muestran el grado de preocupación de Clarke por la

\footnotetext{
${ }^{24}$ Los escritores que participaron en este tributo fueron: Thomas Kinsella, John Montague, Hugh MacDiarmuid, Serge Fauchereau, Padraic Colum, Ted Hughes, Richard Weber, Christopher Ricks, Anthony Kerrigan, Denis Donoghue, Charles Tomlinson, Liam Miller.
} 
mujer bajo las instituciones que dirigían Irlanda. Otros poemas tratan sobre asuntos que tenían relevancia en esos años: "Napalm", "Nova et Vetera", "Pigeon Pie" o "Letter to a Friend".

The Echo at Coole tiene cuarenta y siete poemas, más del doble que Oldfashioned Pilgrimage. El tono es similar, y el contenido temático cambia ligeramente al abandonar los poemas de viajes y centrarse más en la Irlanda contemporánea. El poemario está dividido en cuatro partes. La primera está dedicada a poemas sobre poetas, la mayoría irlandeses - Yeats, AE, James Stephens y F R Higgins; en la segunda aparece un poema sobre Gerard Manley Hopkins; la tercera, en cambio, contiene algunos poemas satíricos dirigidos contra la Iglesia Católica y contra la hipocresía del gobierno que erige nuevos edificios mientras por las calles de Dublín sigue paseándose gente que no tiene donde dormir. Entre ellos se encuentran "New Liberty Hall", "The Vocation", "The Subjection of Women", o "Miss Rosanna Ford", todos ellos comentados en el capítulo IV. La última parte alberga traducciones y versiones de poemas gaélicos clásicos.

A Sermon on Swift apareció publicado también en 1968, y es un poemario corto divido asimismo en cuatro secciones. Aparte de algunos poemas sobre temas relacionados directamente con Irlanda, la mayoría son comentarios sobre asuntos contemporáneos. De todo el poemario destaca "A Sermon On Swift", poema que ya hemos comentado anteriormente y que constituye el tributo de Clarke a la inteligencia, sentido de la moralidad y compasión humana de Swift (Tapping, AC 277). 
Orphide and Other Poems es el penúltimo poemario de Clarke. Contiene cinco poemas relativamente largos y el título es el mismo que el del poema homónimo de la colección: “Orphide”. Según dice Halpern, éste es un poemario agradable y ameno, en el que la destreza poética de Clarke está en plena forma; sin embargo, "he doesn't say anything he hasn't said before, and technically he doesn't do anything he has not done several times before" (131). Quizás los dos poemas más interesantes sean "Orphide" y "The Quarry", poemas que retoman el tema de las apariciones de la Virgen y de las peregrinaciones a Lourdes, y que veremos en el capítulo IV. En el primero, Clarke cuenta la historia de Bernadette de Lourdes, y castiga a la Iglesia Católica y a sus seguidores por perseguir a una simple jovencita que, según Clarke, no era una santa sino una muchacha atormentada por sus alucinaciones y de la que se aprovechó la Iglesia. El poema ataca el materialismo y la falta de sensibilidad de la institución católica. "The Quary" es un pequeño poema sobre una falsa aparición de la Virgen en una cantera en el condado de Donegal, en Irlanda.

La antepenúltima obra de Clarke es Tiresias, compuesta por un largo poema homónimo escrito en hexámetros y en el que retoma la historia de Tiresias, profeta ciego de la ciudad de Tebas, que fue interrogado por Zeus sobre quién de los dos, el hombre o la mujer, obtenía más placer durante el acto sexual, ya que él había experimentado ambos sexos. Tiresias contestó que la mujer, lo cual enfureció a Hera, esposa de Zeus, que no estaba de acuerdo, y dejó ciego a Tiresias. Zeus le 
concedió el don de la profecía ${ }^{25}$. En el poemario anterior, Clarke había usado un relato de la mitología griega para escribir "The Dilemma of Iphis", pero como dice Harmon, "These classical narratives are among Clarke's weakest poems, not because they lack narrative power, but because they are not particularly interesting" ( $A C$ 238). Ambos poemas se centran demasiado en el tema de la sexualidad, y sus descripciones sobre el placer sexual no llegan a convencer al lector, al carecer de la imaginación que tienen otros poemas en los que la sensualidad aflora con más naturalidad. Un excelente ejemplo es "The Young Woman of Beare" de Pilgrima$g e$, en el que la secuencia en que la joven de Beare seduce a un capitán es imaginativa y creíble, y llega al lector con absoluta convicción.

El último poema que escribió Clarke fue "The Wooing of Becfola" (541), y apareció por primera vez en Collected Poems de 1974. Es un poema que cierra la obra literaria de Clarke volviendo a sus orígenes: a la mitología celta. Clarke usa una anécdota sobre Diarmuid, un rey de Irlanda, y su esposa Becfola, quien sale un día a pasear por los bosques y se encuentra con un apuesto joven con el que comparte comida y bebida y con el que pasa la noche, permaneciendo fiel a su marido. Sin embargo, todo ha sido un sueño, que advierte a la mujer de que toda transgresión puede significar destrucción. Es decir, si los placeres sexuales son posibles dentro de la institución del matrimonio, ¿por qué ir a buscarlos fuera de él? El poema es un broche de oro a la obra de Clarke, y nos lleva a los tiempos en que Irlanda tenía una religión propia, sin las constricciones de la Iglesia Católica que intenta imponer el celibato incluso dentro del matrimonio, y no ceja en su intento

\footnotetext{
${ }^{35}$ Este episodio aparece en el Libro III de las Metamorfosis de Ovidio.
} 
de controlar las conciencias individuales hasta límites que, desde el punto de vista de un lector a las puertas del siglo XXI, parecen, si no ridículas, sí completamente anacrónicas. 


\section{2. Austin Clarke y la Tradición.}

Este bosquejo biográfico y literario no estaría completo sin mencionar su obra crítica que, aunque apenas conocida, cumplió una función importante en el panorama literario irlandés. Clarke puso mucha energía en la labor de crítico literario que realizó desde 1917 hasta sus últimos años. Escribió, a veces bajo seudóni$\mathrm{mo}^{26}$, a veces anónimamente, cientos de ensayos y crítica de libros para un buen número de rotativos - entre ellos, The Times Literary Supplement, The London Mercury, The New Statement en Inglaterra, y The Bell, y The Dublin Magazine en Irlanda $-\mathrm{y}$ aunque estos escritos no representan nada que se pueda etiquetar como movimiento de crítica literaria, "They do add up to a significant body of literary criticism written from a distinctly Irish point of view" (Schirmer, "Clarke" 84). Este punto de vista es el de un "insider", el de alguien que conocía la literatura irlandesa de primera mano porque él mismo pertenecía a ella. Su obra crítica es asimismo significativa porque llena el vacío que existía en cuanto a crítica literaria escrita desde un punto de vista irlandés.

De entre toda su labor crítica, hay tres obras importantes: Poetry in Modern Ireland, que está formada por varios artículos que escribió Clarke para la Cultural Relations Committee of Ireland en 1951; The Celtic Twilight and the Nineties, que es una compilación de las conferencias que pronunció en UCD, y que se publicaron en forma de libro en 1969; y dos artículos sobre W. B. Yeats publicados como "Irish Poetry Today".

\footnotetext{
${ }^{36}$ Solía usar A.C., y también M.D., que corresponde a Maurice Devane, protagonista de su poema Mnemosyne Lay in Dust, seudónimo que no escogió por ninguna razón en especial.
} 
Poetry in Modern Ireland es el manifiesto en que Clarke expone sus ideas sobre la independencia de la literatura irlandesa. En él expone su idea de que no hubo un renacimiento literario en los primeros años del siglo $\mathrm{XX}$ sino una continuación de la tradición irlandesa:

Owing to present confusion and neglect, the particular conditions of our poetry are often misunderstood - indeed the fact that critics speak of an Irish literary revival show in itself a certain measure of inaccuracy. We do not speak of an English, French or American literary revival and, and in the strict sense of the word, therefore, it is inaccurate to speak of an Irish literary revival. The movement which expanded so quickly at the beginning of the present century was the result of a gradual development. We can trace that development back to the eighteenth century when the English language spread more widely throughout Ireland and the native language and its literature were in decline. (PMI 6).

La teoría de Clarke es que cuando el Realismo era la corriente literaria predominante en toda Europa, los poetas en Irlanda echaron mano de la mitología irlandesa, lo que quizás, como dice Halpern, "was a delayed reaction to romanticism but it was, in any case, individual and independent" (143). Según Clarke, el Romanticismo del siglo XIX yacía latente en la literatura anglo-irlandesa, y fue aflorando a media que "our writers were discovering directly or indirectly" (PIM 7) el material gaélico. Es conveniente recordar que las literaturas francesas o inglesas recurrían a la mitología griega, e incluso James Joyce recurrió a Homero para escribir Ulysses. Sin embargo, los escritores irlandeses recurrieron a una mitología propia, que había sobrevivido a través de la tradición oral, y que les provocó "an emotion which 
was unknown to English poets, an emotion which gives their work its peculiar intensity" (PMI 8).

En esta misma obra, Clarke ataca al movimiento modernista de las primeras décadas del siglo $\mathrm{XX}$, y lo rechazó tildándolo de insensible e irrelevante para la experiencia irlandesa: "Modernism was a distinctly international movement, and [...] Clarke was suspicious of it precisely because it paid so little heed to national boundaries and cultures" (Schirmer, "Introduction" xiv). Sin embargo, hay que tener en cuenta que Clarke fue un escritor que experimentó este movimiento en persona. Recordemos que, como otros muchos escritores, vivió en Londres en el año 1922, justo en el momento en que Joyce y Eliot publicaron Ulysses y The Waste Land respectivamente, y trabajó como crítico literario, lo que le puso en contacto con todo lo que se publicaba. Para Clarke, el centro de la poesía moderna en inglés no se encontraba en los escritores modernistas - Eliot, Pound, Joycesino en los clásicos como Hardy, Kipling, y Graves; en cuanto a Yeats, Clarke nunca lo consideró un autor modernista: "Regarding his work as a whole, however, we may suspect that Yeats never really left the Celtic Twilight" (MPI 48).

Respecto a su otra obra, The Celtic Twilight and the Nineties está dividida en cinco capitulos: the Nineties, the Celtic Twilight, Victorian Verse Drama, Yeats's Early Plays y Yeats's Later Plays. El primer capítulo está formado por recuerdos personales en los que relata las influencias literarias que afectaron al movimiento francés llamado Fin de Siècle en Irlanda. Clarke vio el movimiento estético decadente de finales del siglo XIX como el predecesor del Celtic Twilight, 
y a Oscar Wild, a quien considera deudor de escritores anglo-irlandeses del siglo XVIII (como George Farquhar, William Congreve, Oliver Goldsmith), como el escritor que puso fin al movimiento esteta de los noventa:

The spectacular downfall of Oscar Wilde, his trail and imprisonment, his miserable death in 1900 , ended and epoch. With righteous selfsatisfaction, the public might well declare: "That is the end of Art for Art's Sake!” (TCTN 30)

El segundo capítulo describe el desarrollo del Celtic Twilight. Clarke no ve una clara diferencia entre las características de este movimiento y las del Fin de Siècle y los interpreta como movimientos nacionales irlandeses con Yeats a la cabeza:

The Celtic Twilight School, of which W. B. Yeats was the acknowledged leader, became fashionable during the nineties, and had considerable influences: its delicate impressionism, its shadowy themes, other-worldly longings and subtle wavering rythms were in accord with the Fin de Siécle Movement. (TCTN 31).

El movimiento Celtic Twilight es, según Clarke, de vital importancia para poder entender a Yeats, y aunque éste lo rechazara, nunca pudo escapar de él, y lo demuestra citando ejemplos como The Tower y poemas como "The Black Tower" y "Cuchulain Comforted" ( $c f$. TCTN 38-39).

El tercer capítulo lo dedica Clarke a las obras dramáticas victorianas escritas en verso, y básicamente es una historia concisa de la dramaturgia en verso, sobre todo de la del siglo XIX. La conclusión a la que llega es que no se escribieron obras dramáticas relevantes durante todo el siglo XIX debido al poco conocimiento de las técnicas de puesta en escena: "Unlike Shakespeare and the other Elizabethan 
dramatists, however, none of these Victorian writers had any practical knowledge of the stage and most of their plays were unactable" (TCTN 50). La época Victoriana tuvo sus grandes poetas, novelistas, críticos e historiadores, pero "no verse drama of consequence" (TCTN 51) Para Clarke, el moderno teatro en verso irlandés nace de la conjunción de John Todhunter y del joven Yeats:

Consciously or not, Yeats realized that in order to start again, it was necessary to break with the stale Victorian pattern of the five act pseudo-Elizabethan tragedies and, in a humble way, be content with lyric plays in one act. (TCTN 73)

Los dos capítulos restantes están dedicados a la obra dramática de Yeats. En ellos Clarke deja a un lado sus sentimientos personales hacia Yeats, y juzga su obra con objetividad: "the Yeatsian line itself was always unique and selfsustained, despite the poet's own susceptibility to the literary moods of his time" (Clarke, "W.B. Yeats" 10). A pesar del desprecio de Yeats hacia Clarke, éste lo trató siempre con respeto, sobre todo porque utilizó elementos irlandeses en su obra: "Yeats, as an artist, was wiser than his contemporaries, for he blended this [vowel] music with the Irish folk lilt and, in the wavering rhythms developed by Moore and Ferguson, found a medium of unusual charm" ("W.B. Yeats" 10).

En la obra crítica de Clarke asoma sobre todo su creencia en la tradición gaélica y en sus posibilidades, y le gustaría ver la literatura anglo-irlandesa dentro de la tradición irlandesa y no inglesa. Su entusiasmo por la tradición gaélica es incontestable: 
Glancing through Irish poetry we notice that it was a medium in which could be expressed the drama of conscience and of inner conflict. We find medieval forms which expressed the natural man as well as his sublimated self of romantic and classical conventions. These forms were common in medieval French lyric, but did not pass into the English lyric tradition. As an example of surviving form, I may mention the Love Songs of Connaught. Their wealth of imagery blinded their first discoverers to the mental conflict, the depth of temptation expressed in them. (Clarke, "Irish Poetry Today" 32) 


\section{I.3. Austin Clarke y W.B. Yeats.}

Yeats muere en 1939, y deja tras de sí a tres poetas de la generación posterior a la suya: Louis MacNeice, Patrick Kavanagh y Austin Clarke. Es ya un lugar común en la literatura irlandesa el hecho de que la generación de poetas irlandeses que surgió después de Yeats estaban no sólo influidos por su estatura artística, sino dominados por el espectro literario de su poesía. Sin embargo, cada uno de ellos quería su propio lugar en el Olimpo literario. Para algunos, "Yeats was rather like an enormous oak-tree, which, of course, kept us in the shade and of course we always hoped that in the end we would reach the sun, but the shadow of that great oak-tree is still there" ${ }^{27}$. Según Garrat, de todos los poetas que siguieron inmediatamente a Yeats, sólo Clarke y Kavanagh (MacNeice es más joven que ellos) desarrollaron una voz poética propia, y su idiosincrasia surgí́ solamente después de una gran lucha artística (MIP 16). Clarke fue tildado de "second Yeats", pero a él nunca le hizo ninguna gracia, ya que no quería ser "Yeats the Second", sino "Clarke the First" (Fallon, 107). A pesar de este apodo, la distinción de poeta más significativo después de Yeats no recayó sobre Clarke, sino sobre Kavanagh,

A poet who made his mark by insisting vehemently on the need for Irish writers to break out of the Yeatsian mold and its commitment to the Irish tradition, and by mocking those writers, including Clarke, who held fast to that commitment ${ }^{28}$. (Schirmer, PAC 4)

\footnotetext{
${ }^{27}$ Citado en Rodgers, Irish Literary Portraits 19.

${ }^{2}$ Según Schirmer, John Montague hizo un comentario en 1957 en el que decía de Kavanagh que era "unquestionably our finest poet", y etiquetó a Clarke como "the acknowledged leader of the "neoGaelic group' " (AC 143).
} 
El deseo de Clarke y de sus contemporáneos por olvidarse de Yeats hizo que se convirtieran en poco menos que herederos y veladores del Resurgimiento Literario Irlandés, transformándose como dijo Samuel Beckett en "romantic antiquarians" ${ }^{\text {29. }}$. Poetas como Kavanagh, Kinsella o Heaney también han tenido que luchar contra la gran influencia de Yeats, pero fue más difícil para Clarke porque éste empezó a escribir durante el periodo en que la reputación de Yeats estaba en su apogeo y porque a Yeats no le gustaba Clarke. No se sabe con seguridad cual fue realmente la causa de la frialdad de Yeats hacia Clarke, pero Schirmer aventura que "it seems to have had something to do with Clarke's friendship wit A.E., with whom Yeats had broken, and, perhaps, something to do with Clarke's short-lived rise to fame with the publication of The Vengeance of Fionn" (PAC 4). Sea como fuere, lo cierto es que Yeats mostró su desprecio excluyendo a Clarke de la antología de poesía que publicó en 1936, Oxford Book of Modern Verse, acción que disgustó profundamente a Clarke.

Independientemente de quien fuera mejor considerado después de Yeats, lo que sí está claro es que Clarke fue otro de los grandes poetas que siguieron a Yeats, y sus logros, aunque diferentes, no dejan de ser sorprendentes. La diferencia fundamental en la poesía de ambos poetas yace en su uso del pasado gaélico. Yeats idealizó lo que él creyó ser una época heroica, mientras que Clarke se introdujo en las formas literarias y en la cultura gaélica para definir el presente, "which he minutely scrutinized, politically, religiously and emotionally" (Tapping, 16). Además, Yeats era de ascendencia británica y protestante, por lo que accedió a la cultu- 
ra gaélica desde fuera. En cambio, Clarke era de estirpe irlandesa y católico. Los conocimientos de gaélico de Clarke hicieron que se acercara a la tradición gaélica desde dentro, a través de la poesía de los bardos, poetas profesionales altamente cualificados y cuya función era diferente de la de los poetas románticos. Según Tapping,

The romantic poet envisages himself as the seer in whose individual imagination is to be conceived the elements of poetic truth. The bardic poet adopted no such pretence; his voice was from within society. Its function was to record, satirise, explain, even to entertain. Its method was its craft, learned by the poet, and in turn developed by him. (1718)

El hecho de elegir la Irlanda medieval como escenario de sus poemas le sirvió a Clarke para intentar ganar a Yeats en dos frentes: la religión y el gaélico. Clarke afirmaba que Yeats había perdido tanto el contacto con la Irlanda católica como sinceridad como poeta, y que las nuevas generaciones tenían que reflejar el verdadero carácter irlandés. Este deseo de deshacerse de la sombra de Yeats permaneció con Clarke toda su vida. Para Clarke, Hyde fue el verdadero inventor de la moderna poesía irlandesa, ya que éste y no Yeats, conocía la lengua y, a través de ésta, la cultura de la antigua Irlanda. Además, fue Hyde quien influyó literariamente por primera vez en el joven Clarke: "Those plain words changed me in a few seconds. The hands of our lost despised centuries were laid on me" (TRBC 167). 
De igual forma que Clarke abandonó la poesía épica para intentar diferenciarse de Yeats, tuvo asimismo que abandonar la época medieval -CeltoRomanesque - como resultado de dos importantes descubrimientos. Uno era su reconocimiento de las trasnochadas cualidades de la mayor parte de la poesía de su generación; el otro es que usando la Irlanda medieval como correlato histórico no había logrado conseguir el objetivo de alejarse de Yeats. En 1936 decidió abandonar la Irlanda medieval y centrarse en el material que le proporcionaría su propia identidad religiosa. Así, "In a huge poetic leap he moved away from the world of the early Yeats and the Revival to the Joycean preoccupation with the makeup of modern Ireland: nationality, religion, and family" (Garrat, MIP 109).

Como ya vimos en el apartado dedicado a la labor crítica de Clarke, éste revisó la obra de Yeats en The Celtic Twilight and the Nineties y en su artículo "W. B. Yeats". En la primera obra hace un repaso de los dramas de Yeats, que situa en tres periodos. El primer drama de Yeats, The Countess Cathleen, no fue bien recibida por la crítica, que la atacó diciendo que carecía de conflicto dramático. Clarke cree que Yeats no sabía lo que hacía en esta primera obra : "had he realized that he was approaching dram from a different angle in his first play and said so, he might have attracted more critical attention. But he did not know what he was doing" TCTN 75). De los primeros dramas de Yeats, dice Clarke que el recitado en verso ralentizaba el ritmo de la obra.

Al contrario que con los primeros dramas, Clarke admira obras como On Baile's Strand, The King's Threshold, o Deirdre, porque en ellas observa las tres 
unidades clásicas de la Poética de Aristóteles, pero a su vez, estas obras habían sido criticadas por la crítica como no realistas. Clarke defiende a Yeats: "But poetic drama is not realistic. The audience will accept stage effects as Shakespeare well knew" (TCTN 89). Los dramas más tardías de Yeats también reciben su dosis de crítica en la obra de Clarke, pero ésta sigue teniendo un tono personal y descriptivo. En los dramas conocidos como "Noh dramas ${ }^{30 "}$ encuentra elementos (espíritus, fantasmas, etc.) que recuerdan la atmósfera romántica del Celtic Twilight: "it is noticeable here how Yeats leaves his new stark style at times and returns to a rich romantic music" (TCTN 94).

Aunque Clarke intenta ser lo más objetivo posible a la hora de juzgar la obra de Yeats, su artículo, “W. B. Yeats" ${ }^{31}$ está teñido de cierta envidia que no logra ocultar:

Yet even in those days of peace the poet's good fortune and success were remarkable. He had patrons, a theatre of his own, a private press, and publishers ready to reprint his ever-changing versions of plays and poems. Even in the windows of the Dublin bookshops his books were a blaze of gold and in each of them appeared a drawing or reproduced painting of the poet - a dim mysterious figure.

Para Clarke, la carrera de Yeats se puede dividir en dos partes. La primera participa de las características del Celtic Twilight; la segunda, en cambio, retoma las

\footnotetext{
${ }^{30}$ Estos son un tipo de drama japonés en el que abundan elementos fantásticos: espíritus, fantasmas y máscaras. Estas le llegaron a Yeats a través de Ezra Pound, quien dijo: "It is a symbolic stage, a drama of masks - at least they have masks for spirits and gods and young women. It is a theatre of which both Mr. Yeats and Mr. Craig may approve" (citado en Richard Ellman, Yeats. The Man and the Masks 216)

${ }^{31}$ Las citas pertenecen a la recopilación de artículos críticos que hace Gregory A. Schirmer.
} 
pautas y esquemas de la poesía inglesa, aunque con una mayor libertad métrica. Para Clarke, sin embargo, el aroma irlandés sigue desprendiéndose en su obra más tardía:

But this new eloquence is not, I think, completely English. It has that individual Anglo-Irish note which one finds in Burke and Grattan and through all this later work there runs the earlier tremulo, starting here and there to surprise us in a sudden snatch. (11)

Cuando Clarke escribió "Irish Poetry Today", a finales de 1936, su pronóstico sobre la poesía irlandesa ofrecía un futuro pesimista: "Irish poetry seems to be rapidly approaching a state of destitution" (26). Esta afirmación no era en absoluto baladí, y las razones que esgrimía Clarke tenían su razón de ser: los grandes poetas del Renacimiento Irlandés estaban desapareciendo de la escena literaria, y cada vez había menos editores interesados en publicar poesía irlandesa. Los editores ingleses tampoco se mostraban muy interesados en esta poesía, principalmente porque los temas irlandeses eran quizás demasiado locales para interesar a un público inglés. Como dice Halpern, "The controversial issues of the day were to become the main subjects of contemporary Irish literature; the land, moral problems, and the expansion of the influence of the Church" (147).

En cierto modo, Clarke culpa a Yeats por haberse vendido, por haber traicionado la causa irlandesa: "An important event which cannot be ignored in any discussion of the present state of Irish poetry is the return of Mr. Yeats to the main sources of English literature" ("Irish Poetry Today" 28). La dedicación de Clarke a 
crear una literatura irlandesa, dentro del idioma inglés, permaneció constante a lo largo de toda su carrera literaria. 


\section{II.4. Austin Clarke y Jonathan Swift.}

Clarke no bebió solamente del legado literario de Yeats, sino también del de Swift. Su obsesión por estos dos escritores demuestra lo importante que fue para él la herencia anglo-irlandesa, y fue con este último con quien sintió una especial afinidad y a quien consideró como uno de sus antepasados literarios. Una mirada atenta a la vida y obra de ambos escritores muestra que hay notables similitudes entre ellos. No sólo el descontento de Swift con su vida en Irlanda encuentra eco en la actitud de Clarke hacia la sociedad irlandesa, sino la técnica satírica, el tono, e incluso el objeto de ataque de sus poemas tienen características totalmente swiftianas. Al igual que Swift "[Clarke] viewed Ireland as a land permeated by philistinism" (Garrat, "Aware” 93).

Clarke no consideraba a Swift como una leyenda literaria, sino como un escritor excéntrico y humorístico que no dudaba en reírse de sí mismo si era preciso. Durante la época de Clarke, la poesía de Swift cobró vigencia, debido principalmente al interés que despertó el olvidado siglo XVIII, en el que la literatura gaélica se fue desvaneciendo al mismo ritmo que transcurrían los días del calendario. Clarke, sin embargo, ubica a Swift en el siglo XVII: "Strictly speaking, Swift really belongs, both in his temperament and his writings, to the seventeenth century, which is still neglected" ("Swift" 128). Tengamos presente que a Swift se le conocía principalmente por su prosa satírica antes que por su poesía. Así, en 1967, Clarke escribe un ensayo titulado "The Poetry of Swift", en el que muestra su admiración por la poesía de éste. Asimismo destaca Clarke la relación de Swift con 
Turlough O Carolan, poeta y compositor irlandés, a quien se atribuye un poema que Swift tradujo del gaélico: "Pléaráca na Ruarcach" (“O’Rourke’s Feast”).

Otro aspecto de la poesía de Swift que menciona Clarke es el de la recepción de sus poemas escatológicos. Durante su vida, estos poemas no hirieron la sensibilidad de sus contemporáneos; sin embargo, en el siguiente siglo, Walter Scott puntualizó: "The Dean neglected both the decency due to his station as a clergyman and a gentleman, and his credit as a man of literature"32. Y, por supuesto, durante la época Victoriana, tanto sus poemas como sus pasajes en prosa no fueron recibidos con los brazos abiertos.

En 1968, Clarke publicó A Sermon on Swift and Other Poems, en el que se incluía el poema homónimo, "A Sermon on Swift" (457-460), y que nos da una idea de lo que Swift significaba para él. El origen del poema está en la conferencia que dio con motivo de la conmemoración en abril de 1967 del tricentenario del nacimiento de Swift. La principal razón por la que se llama "sermon" es que leyó su conferencia desde el púlpito de la Catedral de San Patricio de Dublín, pero también "because the very genre has Swiftian overtones" (Garrat, "Aware" 93).

En el poema de Clarke aparecen elementos en los que se vislumbra la conexión entre Clarke y Swift. En realidad, el poema es una identificación personal del poeta con Swift, quien se dedicó también a observar la sociedad irlandesa con extrema atención. La conexión entre ambos artistas aparece en los comentarios personales que interrumpen el hilo del poema. Las menciones a la obra de Swift y al

\footnotetext{
${ }^{32}$ Citado en Clarke, "The Poetry of Swift"127.
} 
Hospital de San Patricio, fundado por Swift, muestran que la sombra de Swift, al contrario que la de Yeats, protegió e inspiró la pluma de Clarke :

A Tale of a Tub, Gulliver's Travels, fables

And scatological poems, I pennied them on

The Quays, in second-hand book-stalls, when I was young. (29-31)

$\cdots$

Last gift of an unwilling patriot, Swift willed

To us a mansion of forgetfulness. I lodged

There for a year until Erata led me

Beyond the high-walled garden of Memory,

The Fountain of Hope, to the rewarding Gate. (107-111)

Incluso sugiere Clarke que Swift podría estar observándolo con aprobación mientras lee su conferencia desde el púlpito de Swift ${ }^{33}$ :

Gentle of hand, the Dean of St. Patrick's guided

My silence up the steps of the pulpit, put around

My neck the lesser microphone.

'I feel

That you are blessing me, Mr. Dean.' (1-5)

Scarce had I uttered the words,

Dear Friends,

Dear Swiftians'-

When from the eastern window

The pure clear ray, that Swift had known, entered the

Shady church and touched my brow. (34-29

33 Después de que falleciera la reina Ana Estuardo en 1714, Swift volvió a Dublín con el nombramiento de deán de la Catedral de San Patricio. 
Pero es a partir de la reaparición de Clarke en la escena literaria en 1955 cuando la afinidad entre Clarke y Swift se pone de manifiesto. Y no sólo por la semejanza en usar el mismo género literario sino por los objetivos de su sátira. Los poemas de Ancient Lights (1955), Too Great a Vine (1957), The Horse-eaters (1960) y Flight to Africa (1963), atacan principalmente a las instituciones religiosas, políticas y sociales, que restringen la libertad y los derechos del individuo en la sociedad irlandesa. Unos siglos antes, Swift se había ensañado literariamente contra "la hipocresía en el ejercicio de la religión, los abusos de los clérigos y las desviaciones del cristianismo verdadero detectables en el comportamiento de las comunidades principales: la anglicana, la católica y la puritana o presbiteriana" (Hurtley et al. 303), así como contra el Estado de Inglaterra y sus relaciones con Irlanda. 


\section{I.5. Austin Clarke y James Joyce.}

Los poetas que fueron surgiendo en las generaciones posteriores a la de Yeats intentaron definir la tradición literaria irlandesa de una forma diferente de la de éste, lo que les llevó a rechazarle en términos ideológicos y a buscar otra figura que les ofreciera una concepción diferente de la tradición irlandesa. Esta figura sería James Joyce, cuyo uso de estratos sociales más bajos como centro de su obra le serviría a Joyce para desconstruir la Irlanda romántica del Resurgimiento Literario Irlandés, a la vez que abría el camino para que otros artistas exploraran la realidad irlandesa que él había sacado a la luz. El tratamiento de Joyce de experiencias urbanas y católicas ofrecía nuevas posibilidades, y fue él "who most clearly demonstrated how 'to take over' as a literary subject 'the town-life the Anglo-Irish bequeathed to him"' (Johnston, IPAJ 11). Así, Clarke, Kavanagh o Kinsella, entre otros, descubrieron en el trabajo de Joyce la expresión de sus propias experiencias y la encarnación o personificación de la lucha del artista en el mundo moderno (79).

Tanto Joyce como Yeats observaron la Irlanda católica de clase media-baja con ojo crítico. Pero Joyce la miró desde dentro, ya que conocía de primera mano las condiciones terribles de la sociedad que mostraba en su escritura. La condición social de Yeats, al contrario, le mantenía alejado de todo aquello que criticaba, lo cual es perfectamente lógico porque su abolengo protestante le arrastraba irremisiblemente hacia los valores privilegiados de la Ascendancy. Joyce no aceptó la agonizante cultura gaélica ni tampoco la imposición de la cultura inglesa, pero llegó a 
un equilibrio entre ambas posiciones, insistiendo en la realidad de la condición moderna. Ofreciendo, por tanto, una visión personal de la realidad que hacía del aislamiento cultural y espiritual su motivo principal, Joyce ofreció a la siguiente generación de poetas "the means to widen the poetic tradition Yeats had narrowed" (Garrat, MIP 102).

La alternativa que Joyce ofrecía al Resurgimiento Literario Irlandés apareció formulada en "The Holy Office", poema que ridiculiza a los practicantes del Revival, entre ellos Yeats, Lady Gregory, Synge, AE, y otros. La sociedad que Joyce retrata en sus obras se puede resumir en una frase suya, "Life we must accept as we see it before our eyes, men and women as we meet them in the real world, not as we apprehend them in the world of faery" (Joyce, $C W 45$ ), que es un alegato contra el mundo romántico de Yeats y sus seguidores, y el principio que guiaría a los escritores que huían de los preceptos del Resurgimiento Literario en su búsqueda de un modo poético que definiera la nueva Irlanda. La intención artística de Joyce queda resumida en la famosa frase de éste a su editor Grant Richards sobre Dubliners: "I believe that in composing my chapter of moral history in exactly the way I have composed it I have taken the first step towards the spiritual liberation of my country" ${ }^{34}$. De igual manera, ser irlandés para Clarke significaba haber experimentado hasta cierto punto los mismos problemas, tanto mentales, como emocionales y espirituales. Los relatos de Joyce contrarrestaban las fabulosas narraciones romántica sobre la vida irlandesa y presentaban un "nicely polished looking-glass"

\footnotetext{
${ }^{34}$ Citado en Garrat, MIP 88.
} 
en el que los compatriotas ciudadanos de Joyce pudieran verse a sí mismos y observar el mundo a su alrededor. Esto sirvió para liberar a un números de escritores católicos de clase media, "providing them with both the authority and the example they needed to write from experience and from the heart" (Garrat, MIP 88). El lenguaje de Clarke no escapó tampoco a la influencia de Joyce, y en sus poemas abundan los neologismos y los juegos de palabras; sin embargo, nunca llegaría al virtuosismo que mostró Joyce en Ulysses y, por supuesto, en Finnegans Wake.

El contexto joyceano de Clarke empieza con Night and Morning (1938), poemario en el que Clarke expone su crisis espiritual y su conflicto con los dogmas de la Iglesia Católica. En Twice Round the Black Church, Clarke admite que A Portrait of the Artist as a Young Man no sólo había influido en su obra sino que la complementaba también:

The "Portrait of the Artist" had long since become confused with my own memories or had completed them and, set up by his recollecting presence, I heard, as in correspondence, the murmur of classes and chalk squealing on the blackboard until teeth cringed, saw the faces of boys that I had hated and Jesuits in black soutanes, the brass candlesticks turned upon some common lathe that had seemed to him like "the battered mail of angels", and, with heart in shoes, I waited, having had, as I fancied, those thoughts that are forbidden by the Sixth Commandment, for the fatal sound of the sliding panel of the confession box, until suddenly the tenuous voice of Dedalus broke the silence like falling glass - and Jesuits, boys, candlesticks and sins against the Blessed Virgin and all the abracadabra of childhood van- 
ished down the trap-doors of the mind to lie in wait for the next dream or perilous temperature. (26-27)

Clarke reconoció en Stephen Dedalus las mismas experiencias y tensiones que en él mismo y en cualquier otro ciudadano irlandés. Tanto Joyce como Clarke habían ido a Belvedere College. Los dos se exiliaron, aunque Clarke regresó después de diecisiete años para quedarse definitivamente en Irlanda como ya hemos visto. Asimismo, "both were tense, cerebral, introspective men with strong scholastic intellects and European cultures, both had made unorthodox marriages, both had rebelled against their early backgrounds and - a coincidence - each of them had married a woman named Nora" (Fallon 114). Sin embargo, la diferencia entre Joyce y Clarke estriba en el grado de rebeldía que mostraron ante la Iglesia. Clarke carecía del orgullo de Joyce - "By conviction Joyce could not abase himself before Catholic doctrine" (Ellmann, 50)—, pero ansiaba la ruptura definitiva con los dogmas católicos. La decisión de Joyce de abandonar la Iglesia nos la cuenta Richard Ellman en su biografía:

It was becoming clearer to him that, of the two ways of leaving the Church that were open to him, denial and transmutation, he would choose the second. He would retain faith, but with different objects. ...Christianity had subtly evolved in his mind from a religion into a system of metaphors, which as metaphors could claim his fierce allegiance. (65-66)

Es decir, Joyce reemplaza los valores teológicos por valores estéticos. La rebelión de Clarke, en cambio, fue más completa. Las metáforas del Cristianismo no 
son una diversión estética, sino un peligro potencial. Clarke no intenta transmutar su cristianismo; simplemente lo niega. Esto no impide que su poesía abunde en símbolos y metáforas religiosas, cuya función consiste en satirizar y atacar a la ortodoxia católica. Sea como fuere, la religión católica no afectó a los dos escritores por igual. Los dogmas católicos traumatizaron a Clarke de por vida, y en prácticamente todos sus poemarios aparecen poemas satíricos en los que condena el puritanismo y la falta de humanidad con que la Iglesia Católica ejercía su poder en Irlanda. Joyce, en cambio, utilizó la filosofía cristiana para adaptarla a su propia concepción artística. Está claro que, independientemente del tratamiento que cada uno de ellos diera a la religión, ninguno de los dos pudo deshacerse del gran poso que la cultura católica en la que ambos crecieron dejó en sus vidas. Como dice Cranly a Stephen en A Portrait: "It is a curious thing, do you know, Cranly said dispassionately, how your mind is supersaturated with the religion in which you say you disbelieve". Clarke tampoco pudo deshacerse de la huella que dejó en su vida la Iglesia Católica, la cual aparece en toda su obra, especialmente en el poemario Night and Morning.

Otro aspecto importante que ampara a los dos escritores bajo el mismo techo literario es su tratamiento de la ciudad de Dublín, y en el que ambas posturas convergen totalmente. Los poemas de Clarke - aunque unas cuantas décadas más tarde - capturan la misma atmósfera urbana que los relatos de Dubliners. Descripciones realistas de Dublín comparten versos con personajes afectados por la misma parálisis existencial que describía Joyce. Personajes como Martha Blake, Miss 
Marnell, Miss Ford, o Father Eddie Bourke, encerrados en su rutina existencial, recuerdan inmediatamente a los personajes de la obra de Joyce. Pero los personajes de Clarke son más selectivos porque forman parte de una gran estrategia satírica. Gente como Martha Blake o Miss Ford aparecen como víctimas de la Iglesia. La mayoría de estos personajes son testimonio de los abusos de ésta y de las Instituciones irlandesas. Clarke se adentraría en las entrañas de la ciudad y sacaría a la luz sus entresijos en Ancient Lights y, sobre todo, en los poemarios de los años sesenta.

La estrategia que subyace tras los poemas satíricos de estos poemarios sigue las advertencias de Joyce en sus poemas satíricos "The Holy Office", "Gas from the Burner" y en su ensayo "Day of the Rabblement", en donde Joyce postula su idea de que el verdadero artista debe estar separado de las masas y ser crítico con el nacionalismo y los movimientos nacionales. Clarke no pudo ser más crítico con las instituciones que regían la vida irlandesa, y las mostró como fuerzas negativas que dificultaban la vida en Irlanda, fuerzas que Stephen etiquetó como redes. La diana más frecuente es la Iglesia, cuya obsesión con la sexualidad y su puritana postura contra el control de natalidad hacen de la religión católica una fuerza represora en vez de reconfortante.

El tratamiento de Joyce de esos temas identificó la moderna literatura irlandesa como el producto de una mente intrínsecamente irlandesa, reflejando la vida como la vivía la mayoría de la gente (Kinsella, "The Irish Writer" 64). En la aceptación y retrato de esta particular realidad irlandesa, Joyce conectó la literatura del 
siglo XX con los poetas gaélicos de lo siglos XVII y XVIII, que escribían acerca de las experiencias de un pueblo subyugado. Después de Dubliners y Ulysses, la tradición literaria irlandesa se abrió para acoger la cultura urbana popular. Clarke siguió la pauta marcada por Joyce, y empezó a obtener información de asuntos cotidianos, como artículos de periódicos, anuncios, baladas callejeras, etc., y mezcló estas fuentes populares con fuentes más eruditas. Clarke, además de incluir referencias a novelistas irlandeses, también hizo referencia a escritores de los siglos XVII y XVIII, poetas gaélicos como Owen Row O'Sullivan, Brian Merriman y Turlough O'Carolan. 


\section{II.6. Austin Clarke y Patrick Kavanagh.}

Los dos poetas más importantes que surgieron después de Yeats son Austin Clarke y Patrick Kavanagh, y cuando murió Yeats en 1939, se encontraron con una especie de testamento literario en forma de poema ${ }^{35}$ en el que Yeats mostraba a sus sucesores el camino a seguir. Les aconsejaba que aprendieran su oficio, cosa que tanto Clarke como Kavanagh habían aprendido de sobra ${ }^{36}$, y les indicaba los temas sobre los que deberían escribir:

Sing the peasantry, and then

Hard-riding country gentlemen,

The holiness of monks, and after

Porter drinkers' randy laughter; (V. 7-10)

Kavanagh, llevado seguramente por su origen rural, eligió el de los campesinos, aunque éstos no fueran los mismos a los que se refería Yeats, y Clarke se dedicó a los monjes y, sobre todo, a la ciudad de Dublín:

$\mathrm{He}$ is the first poet of the twentieth century to take as his master not Yeats but Joyce, and to place Dublin at the heart of his work. Most of the other Irish poets who were contemporary with Clarke followed the example of Yeats and looked to the countryside. Padraic Colum, James Stephens, F.R. Higgins, Patrick Kavanagh set their poems 'in the land', writing of a pastoral Ireland. (Garrat, "Transition" 106107)

Pero no toda la poesía de Kavanagh sería rural, ya que durante los últimos años de su vida escribió los llamados "Canal Poems", como resultado de los largos paseos

\footnotetext{
${ }^{35}$ Este poema es “Under Ben Bulben”, Yeats's Poems, 451.

${ }^{36}$ Clarke había publicado The Collected Poems en 1936, y Kavanagh Ploughman and Other Poems, en 1934.
} 
al lado del Gran Canal de Dublín cuando se recuperaba de una grave enfermedad pulmonar. Independientemente de los temas que cada uno de estos dos poetas eligiera, lo que está claro es que dividieron la escena poética, y se esforzaron por deshacerse de la gigantesca sombra que el espectro literario de Yeats proyectaba sobre ellos. Ambos poetas, también, a pesar de las similitudes que los unía, compartieron un antagonismo que duraría toda su vida.

Kavanagh nació en el condado de Monaghan en 1904,-el año de Bloomaunque un poco más alto que el propio Mr. Bloom, como dice Hugh Kenner: "Paddy grew an inch taller than Bloom: five feet ten and a half, 190 pounds, 'great roots of hands,' huge feet needing custom shoes, 'a voice like coal sliding down a chute"” (293). Al igual que Clarke, un día, probablemente gris, de Diciembre de 1931, Kavanagh llamó a la puerta de AE, y éste le cargó con una ecléctica colección de libros de Emerson, Whitman, Browning, Hugo, y Dostoyevsky. Para Kavanagh, AE was "the only true friend of the Irish poets"37.

Siguiendo la misma senda que Joyce y Clarke, entre otros, Kavanagh se exilió en Londres en 1938, y aunque no tuvo demasiado éxito, más tarde lamentaría haberse ido de allí. Según Johnston, llegó a afirmar que "if he had remained in London in 1938, he would have conquered that town eventually"38. En 1939, Kavanagh decidió instalarse en un Dublín que no tardaría tampoco en decepcionarle. El año anterior había publicado su primera obra pseudobiográfica ${ }^{39}$, The Green Fool, coincidiendo con el poemario de Clarke Night and Morning que, aunque no

\footnotetext{
${ }^{37}$ Citado en Kenner 296.

${ }^{38}$ Citado en Johnston 4.
} 
es del todo autobiográfico, sí podemos considerarlo como una radiografía de la conciencia del autor en esos años.

Si Clarke dio al mundo literario una versión urbana del drama de la conciencia del pueblo irlandés, Kavanagh ofrecería la versión rural. Para Hugh Kenner, The Great Hunger es a Kavanagh lo que Dubliners es a Joyce - "It is Kavanagh's Dubliners, and his misgivings were like the ones Joyce himself came to have about Dubliners" (303) - , y recordemos que la obra de Joyce representaba asimismo un capítulo moral de Irlanda. En ambos dramas, aparece uno de los grandes temas del conflicto irlandés: la represión sexual. The Great Hunger es un poema amargo y desolador; Patrick Maguire es la sinécdoque del campesinado ávido de sexo y de amor en una sociedad regida por una teología que controla el mismo espíritu de la vida y que se encuentra incrustada en un sistema social implacable. Clarke se concentró principalmente en atacar a la Iglesia Católica, mientras que Kavanagh no solo ataca a la Iglesia sino también al sistema social ${ }^{40}$. Pero a su vez, Kavanagh dirigía también su poema contra la tradición literaria que trivializó el dolor y la humillación que representa Maguire. En palabras de Augustine Martin,

This ... had existed in two versions, each associated with Yeats' Literary Revivial: the mystical Red Hanrahan figure ... and the carefree rural bachelor so prevalent in the kitchen comedies of the Abbey

\footnotetext{
${ }^{39}$ En 1948, publicaría otra obra pseudobiográfica, Tarry Flinn.

to "Rural Ireland remained a deeply conservative patriarchal society, protective in its embrace of its children but harshly impatient with those who stepped out of line, especially if embroiled in a sexual misadventure. The habit of late marriage was widespread: the accompanying ethic of sexual continence was rooted less in the puritanism of the Catholic Church than in the need to avoid further subdivision of family farms to the point where they might be unviable. Accordingly, older inheriting sons ramained "boys" until their ageing parents agreed to make way for a young bride who might start a new family with them on the homestead" (Declan Kiberd, Inventing Ireland 476-7).
} 
Theatre - the broth of a boy who drops in at the house for a bit of craic with the girls, lights his pipe with a twig from the fire, and finally rambles off down the boreen whistling Danny Boy. ("Kavanagh and After" 25-6)

Cuando Kavanagh llegó a Dublín tras su corto exilio londinense, le faltó tiempo para emprender su cruzada personal contra el Resurgimiento Literario Irlandés y sus practicantes, especialmente sus rivales contemporáneos que, como Austin Clarke, buscaban su propio espacio literario en la ciudad de Dublín a finales de los años treinta y durante la década de los cuarenta. Kavanagh nunca mostró mucho afecto por este movimiento literario, y creía que la literatura moderna irlandesa se había formado para deleite de extranjeros, tanto ingleses como americanos, y la consideraba "a thoroughgoing English-bred lie"41 ( $c f$. Brown, "After the Revival" 103; Hurtley et al 169-70). En los años cincuenta, Kavanagh era ya una figura notable en los círculos literarios irlandeses. Era toda una presencia. Clarke, sin embargo, aunque se le considerara como el mejor poeta después de Joyce (y en esto hay divergencias), era

A wraith in all accounts of his era, not least because W.B.Y. helped will his non-existence. His contemporaries weave in and out of printed memoirs: not Clarke. They are themes for Dublin anecdote: not Clarke. Their names turn up in the lists that establish provenance: not Clarke's. (Venner 307-8)

A pesar de su fama, sin embargo, Kavanagh se ganó muchos enemigos gracias a sus sátiras y a los artículos que él mismo escribía y publicaba en su propio

\footnotetext{
${ }^{41}$ Patrick Kavanagh, Self Portrait 9.
} 
periódico, Kavanagh's Weekly, y en el que no dejaba títere con cabeza, atacando a casi todas las figuras consagradas del panorama literario irlandés. El ataque contra Clarke $^{42}$ - especialmente en el poema satírico The Paddiad, donde le tildaba de "demon mediocrity" - se centraba especialmente en el supuesto romanticismo de éste. Kavanagh se empeñó en ubicarlo dentro del círculo de escritores que formaron el Resurgimiento Literario Irlandés, pasando por alto el giro hacia el realismo que Clarke había emprendido con Night and Morning. Además, no pareció nunca haber leído con cuidado a Clarke, pues de haberlo hecho así, se habría dado cuenta de la gran cantidad de similitudes que había entre ellos:

Both poets as young men read and were inspired by the poetry of the Revival; both grew to sense the limitations of the revivalist formula; both became more critical and satirical; and both were influenced by Joyce and cultivated a Joycean dimension in their works. (Garrat, MIP 138)

Así como se puede ver una gran afinidad en las preocupaciones de ambos autores, podemos a su vez observar una gran diferencia en sus estilos literarios. Clarke prefiere un lenguaje concentrado, oscuro, con una extrema atención al detalle y a las rimas; Kavanagh, por el contrario, usa un lenguaje más liviano, más relajado. Como dice Augustin Martin, "Kavanagh seems barely aware of what he is doing, Clarke draws attention to the strategies by which it is all managed" ("Kavanagh and After" 29).

^ Clarke fue asimismo objeto de burla por parte de la pluma de Beckett, que le ridiculizó como "Austin Ticklepenny" en su obra Murphy. 
Es importante la influencia que ambos autores han tenido sobre otros poetas y la que han recibido de otros escritores. Como ya hemos dicho, Yeats arrojó una gran sombra sobre el panorama literario irlandés, y de hecho resultó un problema para sus sucesores, entre los que estaban Clarke, Padraic Fallon, Debis Devlin, Patrick Kavanagh y Louis MacNiece. Mientras Clarke y MacNiece encontraron sus propios métodos para resolver el problema, los otros recurrieron a la poesía americana para deshacerse de la sombra proyectada por Yeats. Sin embargo, Austin Clarke también recibió la influencia americana en un mayor o menor grado. Nos cuenta que fue Longfellow quien le introdujo en el "evocative power of verbal rhythm" (TRBC 160), y Whitman quien le introdujo en un cierto idealismo social. También Whitman le ayudó a establecer un lazo de unión entre la sexualidad y la creatividad literaria que permanecería en toda su obra ${ }^{43}$. En Pilgrimage se perciben esas franquezas whitmanianas que abundan tanto en Leaves of Grass. En cuanto a Kavanagh, la influencia americana es también un hecho en su poesía. Primero, los Imagistas que, según Kavanagh, "excited my clay-heavy mind" ${ }^{44}$ y la obra de Gertrude Stein que "was like whiskey to me, her strange rhythms broke up the cliché formation of my thought" ${ }^{\text {;5; }}$ más tarde, en 1955, Kavanagh descubrió a los poetas de la Beat Generation: "That rascal Alan Ginsberg has made news with the Beat generation. You only have to roar and use bad language. I am genuinely thinking of having a go" ${ }^{\text {"46. }}$. En palabras de Eamon Grennan, "American poetry ... helped

\footnotetext{
${ }^{43} \mathrm{Cf}$ "Old-Fashioned Pilgrimage", poema del volumen del mismo nombre.

" Citado en Eamon Grennan, "American Relations" 97.

${ }^{45}$ Ibid. 97-8.

${ }^{46}$ Ibid. 98 .
} 
Kavanagh free himself of Yeats and secure himself in that poetic identity that we now take as a fresh point of departure for contemporary Irish poetry in English" (“American Relations" 99).

Pero ante todo no hay que olvidar la gran influencia de Joyce. Para Kavanagh, Joyce es el parroquiano por excelencia. Es el escritor que "captured every detail of his parish and turned it into universal significance" (Garrat, 146). Joyce democratizó la tradición irlandesa, llevándola más allá de las sagas heroicas y del folclore que animó a los poetas del Resurgimiento Literario Irlandés. Fue el interés de Joyce por las cosas sencillas, por la vitalidad de lo local, lo que Kavanagh intentó desarrollar en su propia poesía: reflexionar sobre los simples detalles de la vida:

The exciting quality about Joyce is that when you read him you are not told of the large public issues that were agitating the minds of politicians and journalists in those days. Joyce is interested in the mind of a man who has put five shillings on a horse. Joyce takes the unimportant private lives of people and shows that in the end these private lives are the only lives that matter ${ }^{47}$.

Tanto Clarke y Kavanagh también influyeron en otros poetas más jóvenes que ellos. El primero influyó notablemente en Kinsella, como puede observarse en poemas como "Nightwalker" o "Baggot Street Deseta", mientras que el segundo influyó más en Montague y en Heaney. Recordemos, por ejemplo, Death of a

\footnotetext{
${ }^{47}$ Kavanagh's Weekly.31 de Mayo.(1952): 3.
} 
Naturalist, en la que Heaney expresa su reverencia por las cosas comunes, y celebra la granja, la tierra, y el trabajo rutinario propio del hombre rural. 


\section{II.7 Austin Clarke y Thomas Kinsella.}

De igual forma que Clarke bebió de fuentes gaélicas, anglo-irlandesas, e irlandesas, de igual forma también los escritores de las generaciones posteriores a la suya incluirían su poesía en sus influencias. Su huella se podría rastrear en un gran número de escritores, pero nosotros nos vamos a centrar solamente en Thomas Kinsella.

Thomas Kinsella nació en Dublín en 1928, treinta y dos años más tarde que Clarke, una ciudad en la que el hacinamiento al que estaba sometida la población engrosaba unas estadísticas que no favorecían en absoluto a la ciudad. Al igual que Clarke, Kinsella creció en un ambiente católico y urbano. Kinsella siempre profesó un gran respecto por la figura de Austin Clark, a quien dedicó el poema "Magnanimity", y en quien reconoció sus esfuerzos por recuperar la truncada tradición literaria irlandesa. Ambos escritores comparten la misma inquietud por recuperar la literatura gaélica, que fue quedándose relegada al olvido durante las últimas décadas del siglo XVIII, y la misma aversión hacia la Iglesia Católica y el Estado irlandés. Como vimos en la introducción, la obra de Clarke funciona como nexo de unión entre la poesía gaélica y la poesía contemporánea escrita en inglés. En cierto modo, Clarke recupera una tradición literaria que yacía abandonada en los recovecos de la historia irlandesa. Robert Welch así lo afirma: "He has done more than fill a gap; he has restored a voice and given it the substantiality of flowered stone" ("Gaelic Poetic Tradition" 51). 
En realidad, después de la muerte de Yeats y Joyce, los escritores irlandeses se plantean el reconocimiento de una tradición con la que sentirse identificado. Para un poeta inglés no le es difícil echar la vista atrás y encontrar a Wordsworth, Keats, Pope, etc. Un poeta irlandés, por otro lado, encuentra una tradición angloirlandesa, y una irlandesa que había quedado truncada en los albores del siglo XIX. Kinsella no cree en la continuidad de una tradición irlandesa ( $c f$. Johnston 97); sin embargo, al igual que Clarke "has done more than his poetic contemporaries to revitalize that tradition" (Johnston 97). Esta idea la reafirma el propio Kinsella de forma contundente en su artículo "The Irish Writer":

The line begins, again, with Yeats. Then, back for more than a hundred years, there is almost total silence. I believe that silence, on the whole, is the real condition of Irish literature in the nineteenth century - certainly of poetry. [...] If, in the need to identify myself, I look deeper still, what I meet beyond the nineteenth century is a great cultural blur. I must exchange one language for another, my native English for eighteenthe-century Irish. After the dullness of the nineteenth century, eighteenth century Irish poetry is suddenly full of life. (8-9).

Pero tampoco se puede decir que Yeats fuese un representante genuino de esa tradición que quedó rota en el siglo XVIII. Yeats pertenecía a una burguesía Anglo-Irlandesa, y por eso se encontraba inmerso en una tradición en lengua inglesa, con una literatura en lengua inglesa y no irlandesa. Nuevamente acudimos a la opinión de Kinsella, quien ve a Yeats como una figura aislada y separada de la verdadera tradición irlandesa: 
But his living tradition is solely in English. [...] Its literature and its human beings are specialized and cut off, an Anglo-Irish annex to the history of Ireland. [...] It is English literature, not Irish, that lies behind them. $[\ldots]$ But I believe that Yeats's isolation is at least partly a matter of choice. He refuses to come to terms with the real shaping vitality of Ireland where he sees it exists; to take the tradition in any other way would have been to write for Daniel O'Connell's children, for DeValera, for Paudeen at his greasy till. [...] Yeats is of course in the tradition of Irish literature ... but he is isolated in the tradition. $[\ldots] \mathrm{He}$ is isolated from a people whose language is not his own and whose lives, therefore, he cannot touch. (11-12).

El dilema que plantea esta "exclusión" de Yeats del panorama literario está claro: si no es Yeats el heredero de la tradición, ¿qué otra figura podría considerarse como representante de la auténtica tradición? De nuevo la opinión de Kinsella se hace imprescindible

Joyce, with a greatness like Yeats's, was able to reject (that is, accept) the whole tradition as he found it, as it lay in stunned silence, still recovering from the death-blow to the Irish language. Joyce's isolation is a mask. His relationship with the modern world is direct and intimate. He knew the filthy modern tide, and immersed himself in it. $(13-14)$

Pero Kinsella admite que tanto Joyce como Yeats son dos puntos de referencia obligados: "Joyce and Yeats are the two main objects in view; and I think he finds that Joyce is the true father. [...] Yeats stands for the Irish tradition as broken; Joyce stands for it as healed - or healing — from its mutilation" ("The Irish Wri- 
ter" 14). Y aunque la obra poética de Joyce es mínima, su influencia en la poesía del siglo $\mathrm{XX}$ es esencial:

... Joyce seems to have been a natural father figure on many levels. His employmentl of lower- and middle-class life as the marrow of his art deconstructed Romantic Ireland.... Joyce's great achievement came in prose and for that reason did not impose upon Clarke, Kavanagh, Kinsella, and others as directly as Yeats's poetry did. In fact, these younger writers chose to see in Joyce's work the expression of their own experiences and the embodiment of the artist's struggle in the modern world. (Garratt, MIP 79).

Igual que Clarke, Kinsella es un poeta urbano que se ha preocupado por afirmar la modernidad irlandesa, especialmente "in his treatment of psychic material which is utterly Irish Catholic" (Dean, "Unhappy" 64), y como dice Heaney, "[Kinsella] is somewhat akin to the Joyce of The Dubliners who found a form for that unspoken world"48. El mismo tema que Heaney ve en la poesía de Kinsella, éste lo había visto en la de Clarke al revisar el poemario Night and Morning: "a Joycean struggle with issues of conscience and authority, Faith and the Church" ("The Poetic" 133-34).

${ }^{48}$ Citado en Seamus Deane, “Unhappy and at Home: Inrterview with Seamus Heaney”, 64. 
II. LA RELIGIÓN, LA CARNE Y EL ESPÍRITU 
Pilgrimage and Other Poems (1929) marca la transición de la Irlanda mitológica a la Irlanda Medieval en la obra de Austin Clarke. Como indicamos en el capítulo anterior, Clarke quería apartarse del aroma romántico y subjetivo que caracterizaba a la poesía del Resurgimiento Literario Irlandés, y como él mismo dice en sus notas a Collected Poems, "I wanted to explore imaginatively a little of the Celtic Romanesque era and historical periods neglected and almost forgotten except by Gaelic scholars and other specialists" (545). Para autores como Agustine Martin, la idea de apartarse de Yeats y del romanticismo del Revival no es la única razón que tuvo Clarke para acercarse a la época medieval irlandesa. Más bien,

The most obvious reason is that implied in his tendency towards separatism: a deeply religious man, he found himself repelled by the Victorian and Jansenistic version of Catholicism in which he was reared, and later, by what seemed to him an excessive clericalism in presentday Irish society (Martin, "Rediscovery" 413).

Y además está la simple razón de que Clarke admiraba el soberbio florecimiento del arte y la cultura autóctonos que tuvo lugar en los monasterios irlandeses: los espléndidos trabajos de iluminación de libros - como The Book of Kells; el fino trabajo de orfebrería - The Ardagh Chalice o Tara Brooch; y la arquitectura del periodo - la capilla de Cormac en Cashel, entre otras obras. Pero aparte de estas razones, Clarke acomete en este poemario el conflicto entre la religión y el individuo y, dentro de éste, el de la carne y el espíritu. Asimismo, presta su voz a la mujer irlandesa, a quien Clarke ve como víctima del puritanismo de la Iglesia y del Estado en Irlanda. 
Clarke plasma en los diez poemas que forman este volumen la historia y las costumbres de la Edad Media Irlandesa y de la temprana Edad Moderna, periodos que utilizará como correlatos históricos para analizar sobre su propia época. El papel que la Iglesia Católica ha jugado en la constitución política y social de Irlanda es crucial para poder entender los acontecimientos que han modelado este país ${ }^{1}$. Los poemas de Clarke, aunque no siempre históricamente precisos, sí son imaginativamente útiles para comprender el esfuerzo del poeta en conseguir esa reconciliación entre la naturaleza humana y el dogma eclesiástico que tanto la sociedad irlandesa como la sociedad cristiana en general han buscado en vano a lo largo de los siglos. El tratamiento de la historia como metáfora, afín también a escritores como Yeats o Synge, "enables them to mount an attack upon the small and squalid soul of the modern bourgeois by glamorizing either the Ascendancy, the peasantry or the medieval clergy" (Deane 33). En el caso de Clarke, le sirve no sólo para atacar a la clase media aburguesada y al Estado irlandés, sino también para arremeter ferozmente contra la Iglesia Católica en Irlanda. La decisión de Clarke de acercarse a la Irlanda Medieval fue casi epifánica, como bien relata en sus memorias:

For some months I had been thinking over our forgotten medieval Ireland when we almost had a religion of our own (la cursiva es nuestra) and had been searching for some image which would bring me other images. (TRBC 140)

\footnotetext{
' Véase el capítulo IV de esta tesis, en el que hablamos del papel de la mujer en Irlanda.
} 
Y para acercarnos a ese lector informado del que hablábamos en el capítulo introductorio, será importante a lo largo de este estudio echar un vistazo a la historia de la Irlanda medieval para comprender por qué este periodo atrajo tanto a Clarke.

Los poemas de Pilgrimage son una colección de imágenes fijas de una parte de la historia de Irlanda que revelan retazos culturales, artísticos y religiosos de la vida irlandesa. Los periodos que abarca este poemario son el que va desde la introducción del Cristianismo en Irlanda en el siglo V hasta la invasión normanda del siglo XII, que Clarke denomina Celto-Romanesque, y el de la temprana edad moderna irlandesa, que comprende los últimos días de los Condes Anglo-Normandos, la resurgencia gaélica y la derrota de Kinsale.

"Pilgrimage" (153-154), poema con el que arranca el poemario, describe un viaje imaginario que un grupo de peregrinos realiza a los lugares y escenarios que marcan el cenit de la Irlanda medieval de Clarke. El poema tiene una doble función: por un lado celebra los logros artísticos y escolásticos que se llevaron a cabo durante esta época; por otro, contrapone el Cristianismo al paganismo vigente en la sociedad gaélica. El conflicto entre estas dos manifestaciones religiosas nos es mostrado de forma tenue, suave, como si ambas convivieran sin estridencias.

Aunque no se sabe con certeza cuando llegaron los primeros misioneros cristianos a la isla, quizás hacia finales del siglo cuarto o principios del quinto, lo que sí es cierto es que Irlanda debe su cristianización a Bretaña y, particularmente, 
al británico San Patricio. No se sabe mucho de $\mathrm{el}^{2}$, y, sobre todo, se ignoran la fecha de su nacimiento, la fecha en que llegó a Irlanda, y la fecha de su muerte, pero se cree que su misión la realizó durante la primera mitad del siglo quinto. Tampoco se sabe mucho de la organización de la Iglesia durante esos siglos, aunque hay constancia de que durante el siglo sexto, los monasterios proliferaron por toda la isla, y el monacato progresó considerablemente. Según ó Corráin (11), parece ser que los grandes monasterios que surgieron en este periodo no reclaman a Patricio o a sus seguidores como fundadores; más bien, ponen sus miras en la Iglesia Británica. La forma de vida de estos monasterios - retiro espiritual, ascetismo, y estricta disciplina - atrajo el patronazgo de los ricos y poderosos. Los monasterios tenían su propio autogobierno, su propia regla monástica, sus propiedades, y se hicieron portadores de una rica y variada cultura literaria y artística.

En la primera estrofa del poema, Clarke nos introduce en el mundo monástico irlandés a través de un paisaje nebuloso, un paisaje en el que, en palabras de Montague, "those changing veils of rain and mist could not be anywhere else" ("A Tribute" 8), y en el que precisamente esas condiciones meteorológicas esbozadas por Montague impregnan toda la escena de una romántica atemporalidad que traslada al lector a una época en la que el tiempo parecía haberse detenido y donde lo pagano se mezclaba armoniosamente con lo cristiano: "wish on thorn", símbolo de atávicos rituales de fertilidad, convive con los "books in the holy schools", de los

\footnotetext{
2 San Patricio sólo dejó escritas dos obras: sus Confessions y su Letter to the Soldiers of Coroticus. La primera es su biografía espiritual, y la segunda es una carta de protesta contra la esclavitud ( $c f$. Donnchadh Ó Corráin, "Prehistoric and Early Christian Ireland" 10).
} 
clérigos monacales. Los peregrinos visitantes pasan de las primitivas islas Aran a tierra firme, donde florecieron los grandes monasterios irlandeses:

The showery breeze - that plies

A mile from Ara- stood

and took our boat on sand

There by dim wells the women tied

A wish on thorn, while rainfall

Was quiet as the turning of books

In the holy schools at dawn. (5-11)

Fue en el mundo de los grandes monasterios donde se fusionaron las tradiciones cristianas y paganas, adaptándose, en cierto modo, la Iglesia cristiana al paganismo que impregnaba la sociedad. Como resultado, emergió una cultura que era oficialmente Cristiana, pero distintivamente irlandesa, diferente por tanto del resto de la sociedades europeas. Los evangelistas cristianos querían, por supuesto, cambiar las costumbres de esta sociedad, pero habría de ser de forma lenta, ya que no se podía cambiar toda una forma de pensar de la noche a la mañana. Hacia mediados del siglo VI, el Cristianismo era la religión dominante en toda Irlanda; sin embargo, el paganismo permanecía, "even with people who had generations of Christianity behind them" (Corish 4). Quizás la razón principal de que esto fuera así se encuentre en las reglas que dictó el Papa Gregorio el Grande (590-604) en relación a este problema: "pre-Christian religious customs, where they cannot be abolished, are to be given a Christian form and meaning" (Corish 15). Así pues, fue inevitable que la herencia del paganismo no pasara al recién llegado Cristianismo. 
El movimiento monástico llevó al establecimiento de grandes monasterios -Kildare, Cork, Emily, Clonmacnoise, Cashel, etc. - que en realidad eran grandes centros eclesiásticos llamados monastic paruchiae ${ }^{3}$. Algunos de estos centros estaban regidos por ricos y mundanos abades, que contraían matrimonio con mujeres de la alta aristocracia, llevaban la vida de un príncipe, y estaban relacionados con los grandes hombres de la época. Durante los siglos séptimo, octavo y noveno, justo antes de las incursiones vikingas, estos monasterios florecieron en las artes: orfebrería, iluminación de libros, y caligrafía. Los peregrinos del poema visitan dos de estos grandes monasterios, Clonmacnoise y $\mathrm{Cashel}^{4}$, donde pueden admirar la dedicación tanto artística como intelectual a la que se consagraban los monjes:

\section{O Clonmacnoise was crossed}

With light: those cloistered scholars,

Whose knowledge of the gospel

Is cast as metal in pure voices,

Were all rejoicing daily,

And cunning hands with cold and jewels

Brought chalices to flame. (16-22)

\footnotetext{
${ }^{3}$ Fue durante la segunda mitad del siglo sexto cuando se fundaron las grandes ciudades monásticas (cf. Hughes 57-64).

+ Clonmacnoise fue uno de los centros monásticos más grandes e importantes de Irlanda. Lo fundó San Ciarán a mediados del siglo VI. Alcanzó su esplendor hacia el siglo VIII y fue importante por sus talleres de piedra y de metalistería. Su riqueza y accesibilidad le hicieron un objetivo deseado. Entre los años 834 a 1163 fue atacado e incendiado 35 veces tanto por los nativos como por los Vikingos. Los Anglo-Normandos lo atacaron en 1179. Fue destruido finalmente en 1552 por una guarnición inglesa. Los restos del monasterio incluyen ocho iglesias, dos torres redondas, una gran Cruz y una fortificación anglo-normanda (The Oxford Companion to Irish History 100). Es un buen ejemplo del arte Celto-Romanesque ( $c f$. Harmon, AC 260).

Cashel era un centro monástico y una residencia real. También fue durante un tiempo la capital eclesiástica de Munster. Es importante la capilla de Cormac, construida por Cormac MacCarthy en 1134, porque es una buena muestra del estilo Celto-Romanesque. Tiene dos torres y una gran Cruz con una torre redonda ( $c f$. Harmon, AC 260-261).
} 
Para la educación y el aprendizaje, existían las escuelas monásticas, a las que podían asistir laicos, monjes y sacerdotes. Los monasterios eran lugares en los que los hombres se dedicaban tanto a alabar a Dios como a enriquecerse intelectualmente. Como lugares de aprendizaje, los instructores tenían la obligación de formar a sus monjes en el temor a Dios y en el conocimiento de sus omnipotentes actos; por tanto, el estudio de las escrituras, junto con el del arte cristiano, daba a los monjes unos conocimientos completos sobre los temas religiosos de las Escrituras. Desgraciadamente, la mayor parte del primitivo arte cristiano de la Irlanda medieval no ha sobrevivido hasta nuestros días, aunque quedan restos de las grandes cruces labradas que marcaban los límites de los monasterios: la Cruz de las Escrituras permanece aún en pie en el monasterio de Clonmacnoise. Para los peregrinos del poema, la gran Cruz, símbolo de Dios, confirma el lugar como sagrado.

En la tercera estrofa, los peregrinos se encuentran en el monasterio de Cashel, frente a las altas torres que dominan el paisaje. Aquí, un grupo de monjes vestidos de blanco cantan en misa mientras la multitud en ayuno reza fervorosamente:

Loud above the grassland,

In Cashel of the towers,

We heard the yellow candles

The chanting of the hours,

White clergy saying High Mass,

A fasting crowd at prayer

A choir that sang before them; (23-29) 
Y sin entrometerse en la escena en la que los monjes y la gente se entregan a sus tareas religiosas, los peregrinos visitan el monasterio donde pueden apreciar la unión de las dos tradiciones, la pagana y la cristiana:

And in the stained glass the holy day

Was sainted as we passed

Beyond that a chancel where the dragons

Are carved upon the arch. (30-33)

Esta unión de las dos tradiciones queda reforzada en la siguiente estrofa, la cual se centra en objetos que representan la riqueza, el arte y la espiritualidad del monasterio: "Sun braided, rich cloak'd wine-cup", "iron handbells", "great annals in a shrine". Clarke evoca costumbres y sucesos que no son del todo verificables. No hay testimonios de que se llevaran "annals" al campo de batalla para asegurarse la protección de Dios, y ningún rey de Cashel lo hizo nunca (Harmon, AC 64). Los "annals" no son libros sagrados, por lo que no habrían ofrecido ninguna protección en la batalla; sin embargo, sigue comentando Harmon, los O'Donnells del Norte Ilevaban el Cathach ("the Battler") cuando batallaban, pero éste era un libro de salmos y, por tanto, podría esperarse de él que tuviera poderes sobrenaturales. Clarke seguramente utilizó la palabra "annals" por cuestiones de métrica y de estilo:

Great annals in the shrine

A high-king bore to battle:

Where, from the branch of Adam,

The noble forms of language

Brighter than green or blue enamels 


\section{Burned in white bronze - embodied \\ The wings and fiery animals \\ Which veil the chair of God. (37-44)}

La procedencia de las referencias a Adam y su genealogía, así como al libro en el que aparece Dios en su trono no están del todo claras, ya que, como explica Harmon (64), puede que Clarke esté confundiendo diversas fuentes. Lo que sí es cierto es que "wings and fiery animals" sugieren retratos de Cristo entre las cuatro representaciones de los evangelistas que figurativamente empañan la figura de Dios — "veil de chair of God"-, representaciones que, a su vez, pertenecen al Apocalipsis y que estaban presentes en muchos manuscritos medievales, incluido The Book of Kells 5 .

Clarke utiliza el monasterio de Cashell como un lugar sinecdóquico de todo el periodo, y le atribuye no sólo actividades y actitudes, sino también los logros artísticos, espirituales y políticos que aparecen en los libros iluminados. Los “annals", las campanillas que llaman a misa, los cálices labrados, las cruces arquitectónicas, son una muestra de cómo la cultura cristiana, cuyo centro y motor era Dios, se había integrado en la cultura irlandesa, y de cómo la sociedad monacal hizo posible el extraordinario florecimiento del arte autóctono irlandés.

La Iglesia medieval irlandesa era una vasta comunidad formada por monjes estudiosos que se dedicaban al arte y al aprendizaje, y por hombres y mujeres temerosos de Dios que ayunaban y rezaban con fervor en las capillas de los monasterios medievales. El idealizado mundo que Clarke ha recreado en las estrofas ante-

\footnotetext{
${ }^{5}$ Manuscrito iluminado medieval compuesto hacia principios del s. IX (cf. Hurtley et al. 172).
} 
riores contrasta con la realidad del mundo monástico. En la quinta estrofa aparecen "wild confession", "black congregations", y un santo que está reprendiendo a la multitud que ha ido a la montaña sagrada de Croagh Patrick ${ }^{6}$ lamentarse de sus pecados. Estos dos adjetivos son precisos y, por supuesto, muy poco románticos. La confesión de los peregrinos es "agreste", su color es "negro", y las ropas que llevaba el clero en la Edad Media eran blancas, contrastando así la pureza de unos con la negrura de los pecados que llevan los peregrinos en el alma. Pero, además, los monasterios tenían otra cara que era menos atractiva: el extremo ascetismo de la vida monacal. La última estrofa pone de manifiesto el contraste entre éste y el materialismo de la vida fuera del monasterio: la imagen de ricos mercaderes de vino que se pasan el día durmiendo colisiona con la dura y aislada vida de los culdees $^{7}$, que rezan en una isla baldía y alaban el Paraíso día y noche. Sin embargo, el poema termina con una sugestiva imagen religiosa en la palabra "kneeling", que le recuerda al lector que la experiencia religiosa no puede rechazarse totalmente una vez que se ha experimentado. Esto nos recuerda inmediatamente las palabras que Cranly le dijo a Stephen en A Portrait of the Artist as a Young Man, y que ya mencionamos en el capítulo anterior. En esta estrofa Clarke muestra cómo la religión

\footnotetext{
6 "Montaña sagrada que se alza sobre la bahía de Clew en el condado de Mayo. El último domingo de julio de cada año se convierte en centro de culto católico al que acuden unos 60.000 peregrinos" (Hurtley et al. 64). El peregrinaje sobrevivió a la Reforma y, gracias a su elemento de penitencia, fue aprobado en el Concilio de Trento. Se revivió en 1903 y sobrevivió a los cambios del Concilio Vaticano II (The Oxford Companion to Irish History 126-127).

${ }^{7}$ Del gaélico Céile Dé. Durante la segunda mitad del siglo octavo hubo muchos movimientos reformadores de la iglesia occidental. Los líderes reformadores en Irlanda se llamaban Céli Dé, que puede significar servus dei (siervos de Dios). Afirmaban que eran siervos de Dios y no de un abad o monasterio. Fueron críticos con la falta de rigor de los monasterios, pero no se propusieron reemplazarla. Lo que proponían era la reforma del monacato (Corish 21-22).
} 
es uno de los elementos clave en el conflicto que atormenta al individuo $y$, por extensión, del pueblo irlandés.

Los peregrinos se alejan en el barco en el que han venido mientras los rezos de los "servidores de Dios" nos llevan a otra isla desolada y baldía donde un eremita se enfrenta a sus propios instintos naturales, que le persiguen en forma de mujer. En "Celibacy" (155-156), Clarke satiriza la disciplina de la vida del asceta, y para ello adopta la máscara de un ermitaño que intenta huir de la tentación que le acosa. La batalla entre la sensualidad humana y la dura disciplina espiritual que demandan los votos religiosos se libra en el lado no visible del monacato, es decir, en el de la conciencia. Según Schirmer, este conflicto "was at least as alive in the Ireland of his own day as it was in the monasteries and hermit-caves of medieval Ireland" (PAC 26). Con la metáfora histórica, Clarke obtiene la suficiente distancia para poder comentar los rigores que la religión sigue imponiendo sobre la conciencia humana en su propia época. Habrá, no obstante, una gran diferencia con la moderna Iglesia Católica: ésta no es tan tolerante como la Iglesia medieval, que incluía elementos paganos que provenían de las costumbres pre-cristianas, y cuya actitud hacia el celibato no era tan intransigente.

La implantación del Cristianismo en Irlanda afectó sobremanera a la institución del matrimonio. Para empezar, estaba el conflicto entre la ley civil y la eclesiástica. Ésta prohibía los matrimonio entre parientes hasta un grado de consanguinidad difícil de observar en la sociedad irlandesa; aquella reconocía matrimonios que no eran ni permanentes ni monógamos. A la Iglesia le ha sido siempre difícil 
imponer la idea de que el matrimonio era un lazo sagrado y para toda la vida. En la temprana Europa medieval, la ley civil contemplaba el matrimonio como un contrato que podía terminar ante ciertas circunstancias ${ }^{8}$. En Irlanda, la forma en que la sociedad estaba formada exigía la existencia del divorcio y del concubinato, especialmente en los casos en que los nobles necesitaban hijos varones sobre los que delegar su poder o a los que transferir sus posesiones.

El matrimonio, por tanto, era inestable. Divorciarse y volverse a casar estaba a la orden del día, y la poligamia, que era practicada por las clases superiores, no estaba del todo mal vista. Esto no era consecuencia de la supervivencia de costumbres paganas solamente, sino que se remontaba al Derecho Común romano y a las actitudes hacia el matrimonio pre-agustinianas ( $c f$. Ó Corráin 21). El Penitencial de Vinnian del siglo VI, por ejemplo, contenía un severo código de moralidad para los cristianos, especialmente en lo relativo a la moralidad sexual. No hacía concesiones a una sociedad acostumbrada a divorciarse, a volverse a casar, a practicar el concubinato. Aunque se hicieron esfuerzos para regularizar el matrimonio, no se logró apenas nada, y la poligamia se practicó hasta finales de la Edad Media, lo cual escandalizó tanto a reformadores como a observadores.

En cuanto al matrimonio dentro del clero, existe evidencia de que se practicaba, aunque no sin un cierto grado de controversia. La práctica del celibato empezó como una costumbre asceta severa, y su aceptación variaba en los diferentes países europeos. Hasta el siglo IV, la igiesia había aceptado que los hombres casados que se ordenaran sacerdotes continuaran viviendo con sus esposas (Hughes

\footnotetext{
${ }^{8}$ Para más información, véase Patrick J. Corish 17. 98
} 
43), y además los juristas civiles podían evadir el problema diciéndoles a los críticos eclesiásticos que en el Antiguo Testamento "the chosen people of God lived in plurality of unions" (Corish 17). Durante finales del siglo VI y principios del VII, los cánones de juristas como Vinnian y Columbanos ${ }^{9}$ establecían que si "a clerit cohabits with his former wife he commits a sin as great as by cohabiting with a casual stranger" (Hughes 51). Además, aunque la tradición asceta rechazaba el matrimonio clerical, había miembros del clero que estaban casados, y que la ley civil réconocía el matrimonio tanto de sacerdotes como de obispos, por lo que es difícil explicar cómo podía ponerse en práctica el celibato cuando parte del clero seguía viviendo con sus esposas (Corish 17).

Pero volvamos a "Celibacy". Éste es un poema en el que un ermitaño es acosado por la tentación de la carne en forma de mujer. Clarke satiriza el hecho de que algo tan natural como es la propia sensualidad humana le traiga de cabeza a un pobre y anónimo ermitaño; sin embargo, aunque ridiculiza la situación, no resuelve el conflicto, y esto es importante porque no será hasta mucho más tarde en su poesía cuando le sea posible acercarse de forma más mediadora al conflicto interno que tanto a él, como poeta, al ermitaño, como siervo de Dios, y al ciudadano irlandés, como católico, les atormenta.

La escena difiere sustancialmente en modo y tono de la escena de "Pilgrimage". Encontramos, no obstante, un elemento de transición: la isla baldía y estéril en que unos culdees elevaban sus rezos al cielo nos transporta a otra isla

\footnotetext{
${ }^{9}$ Estos fueron dos legisladores que, entre otras cosas, condenaron la continuidad de relaciones sexuales en el matrimonio del clero ( $c f$. Patrick J. Corish 10-12).
} 
igualmente desolada donde un eremita libra batalla contra sus instintos sexuales. Las imágenes que usa Clarke muestran el estado de soledad y penitencia en el que vive el monje - "nettle", "straw", "flagstone", "cold water", "a bare island", "thistle", "reed" - y dan al lector una sensación de austeridad que es difîcil de imaginar. Las ortigas para la flagelación, la paja y la fría piedra sobre las que dormir, el agua fría para mantener la temperatura del cuerpo lejos de toda excitación sexual, y los cardos y juncos del río, junto con la esterilidad de la isla, son imágenes de una disciplina rayana en el absurdo. Clarke parece preguntarse si es necesario tanto rigor espiritual para vivir en armonía con Dios y con su Iglesia. Martin ve este mundo medieval de Clarke como "one of Manichean extremes - extremes of austerity and sensuality, of learning and ignorance, of saintliness and profanity, of religious discipline and civic anarchy" ("Rediscovery" 415).

Recordemos que el monacato nació en Egipto y era elegido por aquellos que querían huir de la civilización. Para ello, se iban al desierto y llevaban una vida contemplativa donde la soledad y el ayuno eran sus únicos compañeros. Los monjes en Irlanda eran creativos y florecieron intelectualmente, pero "the daily life of the monk was girt round with austerity" (Corish 12). En el poema, el monje vive solo, "On a brown isle of Lough Corrib" (1), y está continuamente acosado por la tentación de los deseos carnales sin que le sea posible deshacerse de ella. El eremita se queja, "But still that woman stayed" (6); y gime, "I groaned / ...of help / to pluck her from my body" (10-12); y combate, "All night by tempting flesh / I wrestled her in hair-shirt" (20-21); y ella insiste, y él sigue huyendo, "She pulled 
me down to sleep / But I fled as the Baptist" (26-27); pero, al final, la tentación vence, "But fiery as the frost / Or bladed light, she drew / the reeds back" (31-33).

El poema se burla del severo ascetismo del monacato medieval, cuyas ex igencias son demasiado severas para ser reales. La última estrofa empieza afirman=do que los dragones de las creencias paganas han sido vencidos por el Cristianismo, pero como vemos en la misma estrofa, la tentación no se vence fácilmente:

The dragons of the Gospel

Are cast by bell and crook;

But fiery as the frost

Or bladed light, she drew

The reeds back, when I fought

The arrow-headed airs

That darken on the water. (29-35)

Clarke compara a la mujer tentadora con las fuerzas de la naturaleza, insinuando que el instinto natural humano es tan fuerte como la propia naturaleza. Así, la mujer es como "fiery frost", "bladed light" y "arrow-headed airs"10, imágenes todas ellas modificadas por adjetivos violentos y potencialmente peligrosos. Es decir, las reglas impuestas por el Cristianismo no pueden competir con los instintos naturales del hombre.

Como vemos, el conflicto está entre los valores establecidos de la respetabilidad moral y los de la experiencia sensual, y, en este poema en concreto, entre los que impone la Iglesia y los que demanda la naturaleza humana. Asimismo obser-

\footnotetext{
${ }^{10}$ En este contexto, 'arrow-headed' significa 'sharp', cortante, afilado. Es decir, los vientos afilados o cortantes.
} 
vamos que la figura protagonista de esa sensualidad, de' la experiencia libre sin ataduras morales está encarnada por la mujer, que también será la protagonista de otros poemas de Pilgrimage y del resto de la obra literaria de Clarke. Para nuestro poeta,

Woman is a kind of intermediary between the poet and his chosen world, whether it is mythic, historical or contemporary. She is the human figure who repeatedly comes closest to Clarke emotional landscape, mediating between the reality of the text and his own occluded sensibility. ... The sensual female reflected and validated the poet's own inclinations so that the acceptance he craved could in fact be found in the act of writing. (Collins 28)

El hecho de que sea la mujer la que esté más próxima al paisaje emocional de Clarke no se debe solamente a la especial sensibilidad que muestra el poeta hacia la mujer en toda su obra, sino también al papel que ésta ha desempeñado en la historia de Irlanda". En este caso es necesario recordar el papel de la mujer en relación con la poesía gaélica y con Irlanda. Según Kiberd (“Irish” 236), todo empieza con uno de los conceptos más antiguos de la tradición bárdica que es el de que la tierra era una mujer a la que adorar, o por la que llorar o luchar. Pero antes hay que entender otra metáfora según la cual el poeta estaba casado con su jefe o patrón (chieftain). Esta androginia en la que un poeta adopta la máscara de una mujer fue empleada por muchos poetas del Revival ${ }^{12}$. Así, en este simbólico matrimonio, el poeta predecía la suerte de la tierra poseída por su señor. Si el dueño

\footnotetext{
${ }^{11}$ Véase el capítulo IV de esta tesis para mayor información.

12 Entre ellos Pearse o Yeats, de quien "Crazy Jane" es un buen ejemplo.
} 
era sabio y bueno, entonces la tierra era fértil y bella, y si el señor era malvado o incompetente, la tierra era estéril, lo que originó, a su vez, la idea de ver a Irlanda como una mujer. Además, los poetas gaélicos imaginaban a su monarca casado con la tierra, la cual estaba simbolizada por una bella mujer ${ }^{13}$.

En los poemas "The Confession of Queen Gormlai" y "The Young Woman of Beare", Clarke adopta la máscara de una mujer, en la mejor tradición de la poesía de los bardos irlandeses. Ambos poemas funcionan desde el punto de vista del individuo que no ha restringido sus impulsos naturales: las protagonistas son dos mujeres que han disfrutado de los placeres carnales a pesar de conocer la desaprobación eclesiástica. En los dos casos, sin embargo, creemos que aunque han pasado por alto los preceptos religiosos, sus conciencias entran en el mismo conflicto que atormentaba la conciencia del eremita de "Celibacy" y, en definitiva, de Clarke y de todo el pueblo irlandés.

En "The Confession of Queen Gormlai" (156-162), Clarke explora y contrapone de nuevo la dicotomía sensualidad y espiritualidad. Gormlai narra sus tres experiencias matrimoniales a un monje que ha venido a escuchar su confesión. El relato está enmarcado por dos estrofas en cursiva, que muestran el estado de pobreza, tanto material como espiritual, al que ha llegado la protagonista del poema, que, habiendo conocido riquezas y placeres en otro tiempo, yace ahora en una mísera choza "Turning in straw and rags" (6).

\footnotetext{
${ }^{13}$ Esta idea está excelentemente reflejada en el poema "The Marriage Night", comentado más adelante.
} 
El relato de Gormlai no es históricamente exacto y, forma parte de las leyendas irlandesas ${ }^{14}$. Gormlai era la hija de Flann Sinna, rey de Irlanda, y se casó con Cormac mac Cuilennain, obispo de Cashel y rey de Munster en el siglo $\mathrm{X}^{15}$. Cuando éste tomó votos religiosos, el matrimonio se anuló, y el padre de Görmlai acordó otro matrimonio con Carrol de Leinster, con quien Gormlai se casó a la fuerza. Éste y el padre de Gormlai declararon la guerra a Cormac, a quien mataron y decapitaron en la batalla de Belamoon. Carrol resultó herido en la batalla, y después de maltratar a su esposa por lamentar la mutilación de Cormac, ésta le abandona y aquél muere poco después. Gormlai está libre de nuevo y se enamora de Nial Glundubh, príncipe de Ulster, que más tarde se convertiría en rey de Irlanda. Sin embargo, en una batalla contra los daneses cerca de Dublín es herido y muere dejando a Gormlai sola y desesperada. Su hijo (el de Gormlai y Nial), además, había muerto poco antes ahogado, lo que aumenta el grado de abandono de Gormlai. Según la tradición, ésta vivió en la más absoluta pobreza y se refugió en una choza, donde murió al caerse sobre uno de los soportes de la cama cuando intentaba perseguir una visión de su amado Nial. Todo parece indicar que su desolación y posterior muerte fueron el castigo a una vida disoluta con tres maridos.

\footnotetext{
${ }^{14}$ Las fuentes de donde Clarke obtuvo posiblemente la leyenda de Gormlai son: "Annals of Clonmacnoise (Ed.) Rev Denis Murphy, Dublin: University Press, 1896, p 145; Eugene O'Curry Lectures on the Manuscript Materials of Ancient Irish History, Dublin: James Duffy, 1861, pp 131-135; Douglas Hyde A Literary History of Ireland, London: T. Fisher Unwin 1899, p 421, pp. 425-6. George Sigerson Bards of the Gael and Gall, London: T. Fisher Unwin 1897, pp 414-416." (Harmon, AC 261). Gregory A. Schirmer cita solamente como posible fuente la obra de Sigerson, a quien Clarke admiraba (PAC 152).

15 'Cormac mac Cuileannáin, likewise King of Munster, scholar, bishop and celibate, died in battle in 908 , a battle he would have wished to have avoided but which was forced on him by dynastic politics. All that was Christian in Ireland recognised him as a saint and martyr, and it may well be said that the cause of his martyrdom was the limitations of Irish Christianity in his day" (Corish 26).
} 
En la segunda estrofa, Gormlai empieza su confesión en un estado de evidente angustia mental, "my mind is stirred" (13), y en las siguientes recuerda su vida entre riquezas cuando vivía en Cashel y era feliz con Cormac: "But I laughed with grave Cormac / Above the candle-rows" (37-38). Sin embargo, éste fue nombrado obispo de Cashel y prefirió no descuidar sus votos religiosos:

His dogs had dashed a white stag,

The day that Cormac bared

Himself upon the flagstone

And was alone in prayer.

All night he turned to God

Because the body dies; (41-46)

Estas líneas nos recuerdan inmediatamente al eremita de "Celibacy", pero, como hemos visto anteriormente, aunque la imposición del celibato en la Irlanda medieval no era estricta, Cormac sí decidió separar lo religioso de lo mundano, descuidando a su vez las obligaciones que el matrimonio conlleva. Es Gormlai quien pregunta al monje que le está escuchando en confesión: "But had it been immodest / For him to rest beside me?" (47-48), es decir, ¿por qué han de estar reñidos los deberes conyugales con los deberes espirituales?, pregunta que lleva igualmente al lector a cuestionarse por qué han de estar en polos opuestos lo espiritual y lo sensual, haya matrimonio de por medio o no. Gormalai sigue diciéndole al monje:

I had not read in book

That goodness can insult

The mind, that meeting looks

Are bright adultery.

Though I have lain in three beds 
And many have blamed me,

No man has seen me naked,

Partaken in my shame. (49-56)

Pero a pesar de todo, su matrimonio con Cormac es anulado por la Iglesia:

Our marriage was annulled,

The Mass bell rung by force

The flesh that was made one,

Divided and divorced. (61-64)

El tono con que se expresa Gormlai es de pesar y de impotencia al no entender por qué los votos religiosos han oponerse a los del matrimonio. Ella amaba a Cormac, pero su amor pasa a un segundo plano favoreciendo a la ley eclesiástica. En la estrofa novena, cuando su padre, Flann, casa a su hija con Carrol mediante un acuerdo para ampliar el territorio- "And joined our lands in marriage" (67)Gormlai teme que haya una guerra contra Cormac, la cual no tardará en acontecer y en la que éste es muerto por las fuerzas de Carrol y Flann. La estrofa que describe la muerte de Cormac no es históricamente exacta, como indicábamos anteriormente, pero la forma en que la relata la protagonista tiene la suficiente fuerza dramática para obviar su inexactitud. En realidad, Gormlai quería a su primer marido, a pesar de que éste la rechazara a cambio de los votos religiosos.

Gormlai describe a su segundo marido como una persona cruel, violenta y lujuriosa, que desde el primer momento no mostró apenas afecto por su esposa. En la novena estrofa, su marido, al que califica de "Black bridegroom of sin" (68), despide a los músicos y al escriba de su esposa, es decir, rechaza lo que a ella le era más querido, con lo que demuestra lo poco que representa sentimentalmente 
para él. Recuérdese que éste fue un matrimonio para unir territorios, no para unir corazones. Y en la siguiente estrofa, Gormlai libera sus airados sentimientos en el fiel retrato de quien le dieron por marido:

He drank at posted fires

Where armies had been glutted

And he shrank bars of iron

Whenever his hand shut.

At night was it not lust

Though I were fast in prayers

For Carrol with his muscle

To thrust me in black hair? (73-80)

Clarke ha escogido cuidadosamente los verbos de esta estrofa, 'drank', "shrank", "glutted", "shut" y "thrust", todos ellos violentos en el contexto del poema. Las últimas líneas, en concreto, parecen aludir a la violación de Gormlai por parte de su marido, y ésta vuelve a interrogar al monje sobre la actuación de su marido dentro de los márgenes del matrimonio: ¿es lícita la violencia dentro de los lazos matrimoniales? Cuando Carrol es herido en batalla, Gormlai interpela al monje y le explica: "With my own hands I nursed / That big man in the blanket: / His wife took sweat and purge" (94-96), y éste, Carrol, rechazó sus cuidados insultándola y dejándola abandonada y sin nada:

Turning upon his sick-bed

He kicked me with foul words

And my pale household fled-

O man within the cowl! (101-104) 
Después de dos matrimonio fracasados, Gormlai se enamora de Nial Glundubh. El recuerdo de los desagradables sucesos que vivió con sus otros dos maridos, especialmente con Carroll, contrasta vivamente con su nueva relación que, al contrario que las anteriores, está fundamentada en el amor:

Two husbands had not fasted

With me - and they were slain.

One turned my soul at Cashel:

His powerful foe had shamed

The bed. All blame a widow

That rids herself of grief.

But, Nial the day you rode back

I came with oils and mead. (113-120)

Los dos amantes huyen, y en su viaje disfrutan de la belleza del amor libre, de lo cual se arrepienten más tarde, "with penance on bare feet" (146). Esta vez, aparte de la condena sistemática de la sociedad - “...All blame a widow / That rids herself of grief" (177-118) -, el peso de la culpa que la religión impone sobre sus conciencias es tan grande que Gormlai llega a la amarga conclusión de que todo el sexo es pecaminoso, incluso el amor dentro del matrimonio - “... Yearly parents, / Your pleasures are unchaste" (167-168); y aunque se arrepiente igual que su primer marido - "But Cormac wore the shirt / of Fire, the shoes of stone" (159160) - ella no se siente libre de pecado: "I am impure with love" (184). En su confesión, no obstante, defiende a su tercer matrimonio, y sus palabras dejan entrever una nota de fe en el amor humano, que es la misma fe que Clarke mostrará en toda su obra, en clara oposición a la falta de humanidad de las instituciones. La 
estrofa que cierra el poema, paradójicamente, parece expresar lo contrario: es decir, que su vida no ha sido más que un pecado:

At sun, she lay forsaken

And in red hair, she dragged

Her arms, around the stake

Of that wild bed, from rags

That cut the gleam of chin

And hip men had desired:

Murmuring of the sins

Whose hunger is the mind. (185-192)

o en palabras de Schirmer,

Human love is, after all, transitory, and it has left Gormlai with nothing but memories and the fear that she may have been wrong, that her life may have been one of prideful sin. Perhaps for that reason she feels forsaken. (PAC 35)

El poema también deja claro que no parece que haya un término medio adecuado para resolver el dilema entre cuerpo y alma, entre lo carnal y lo espiritual. Las preguntas que Gormlai formula al monje, como representante de la Iglesia, quedan sin contestación, quizás porque el monje mismo no tiene las respuestas adecuadas. Sin embargo, una total negación del aspecto religioso como posible solución no sólo sería imposible sino también indeseable, y éste es el tema central en el conflicto de Clarke, entre sus experiencias religiosas y su visión humana del hombre. Gormlai yace ahora en una choza completamente abandonada a su suerte. El amor humano ya no le sirve de nada, y ahora busca consuelo en la confesión, la 
cual no parece que consiga sosegar su conciencia. Como dice Clarke, su conciencia "may symbolise a conscience wounded by others"16.

Así como Gormlai pone de relieve la palabra "love", la jovencita protagonista del poema "The Young Woman of Beare" se inclinará más por la pälabra "flesh". El conflicto entre Cristianismo y deseo individual, entre las reclamaciones espirituales de la Iglesia y los placeres del cuerpo - ya sean sensuales o materiales - que la religión católica se empeña en condenar tan obstinadamente, vuelve a ser el tema central de este poema.

"The Young Woman of Beare"17 (163-170) tiene su origen en un antiguo poema anónimo escrito en gaélico, "The Old Woman of Beare"18. La explicación de los episodios del poema nos la da Clarke en sus Notas a Collected Poems (1936):

The episodes of the allegory are fanciful, but the Old Woman of Beare, or Berehaven in Kerry, is a well-known figure in country stories. She had seven periods of youth before the climacteric of her grief. She speaks in a famous and classic poem; 'the lament of an old hetaira who contrasts the privation and suffering of her old age with the pleasures of her youth when she had been the delight of kings' (Kuno Meyer). ...The legend still lives giving nobility to the contrariety of human nature. (312)

\footnotetext{
${ }^{16}$ Citado en las notas a Collected Poems (1974) 548.

17 "Beare" es el nombre de una península en el oeste de Irlanda. También la abreviatura de Castletown Bearhaven, en el condado de Cork.

${ }^{18}$ También se la conoce como "The Old Hag of Beara", que era una "figura de la mitología celta que representa a una diosa trina, esposa de Lugh" y que al parecer "protagonizó una disputa con otra diosa en la península de Beara.... En The Book of Lecan se cuenta que disfrutó de siete períodos de juventud y tuvo siete maridos que le aportaron cincuenta hijastros.... La tradición ha propagado su figura como emblema de inmortalidad" (Hurtley et al 243). Aparte de Austin Clarke, otros autores se han basado en la misma figura, como Michael Hartnett en The Hag of Beara (1969).
} 
Pero el nuevo poema difiere del antiguo en varios aspectos. Para empezar, el poema "The Old Woman of Beare" está enmarcado en el tópico tempus fugit, y en él la protagonista rememora con una mezcla de orgullo, nostalgia y agrado los placeres que disfrutó durante su juventud. Para Denman, "it is a poem of loss" (67), la pérdida de la juventud que ya no puede recuperar. En la traducción de Brendan Kennelly (PBIV 62-63), la anciana de Beare nos dice:

The Old Woman of Beare am I

Who once was beautiful.

Now all I know is how to die.

I'll do it well.

Look at my skin

Stretched tight on the bone.

Where kings have pressed their lips,

The pain, the pain. (7-14)

Y a diferencia del poema de Clarke, éste no es un poema en el que entren en conflicto el deseo sexual y las reglas ortodoxas de la Iglesia, sino solamente aquél y el paso del tiempo. La anciana de Beare se lamenta de que no puede volver a ser joven, y su ira no se vuelve contra los hombres que pueden haberla engañado o no, sino contra las mujeres más jóvenes que pueden seguir disfrutando de lo que ella, desgraciadamente, ya no puede:

I don't hate the men

Who swore the truth was in their lies.

One thing alone I hate

Women's eyes. (15-18) 
También se queja de la falta de amor verdadero de las mujeres actuales. Para ella,

Women love only money now.

But when

I loved, I loved

Young men (25-28).

Y éste es una aspecto importante porque para la joven de Beare la palabra "amor" apenas cuenta, como, por ejemplo, contaba para Gormlai. Nuestra joven protagonista es la voz del deseo sexual, y se siente envidiosa de los casados porque pueden disfrutar de lo que a ella se le niega.

El poema de Clarke no es un lamento por la juventud perdida; es, al contrario, una amarga queja por el mero hecho de seguir siendo joven. A la protagonista le es imposible envejecer, lo cual la condena a una eterna contienda entre su deseo sexual y los dogmas de la Iglesia. Creemos, además, que Clarke revierte el tópico horaciano de collige virgo rosas o carpe diem. La jovencita del poema ha disfrutado de los placeres que su cuerpo le ha pedido, y en vez de apremiar a las demás mujeres a que disfruten de la primavera de su vida antes de que pase el tiempo y se marchiten sus rosas horacianas, les ruega que hagan todo lo contrario: "Young girls, keep from dance-hall / And dark side of the road" (81-82) y "Women, obey the mission - / Be modest in your clothes" (131-132). El tópico del carpe diem, en el que el amante rogaba a su dama que disfrutara de la vida, lo recogió la tradición medieval y lo conservó con cierto aroma pagano. En este poema, Clarke subvierte el sentido, porque los dogmas religiosos impiden una completa realización de la propia naturaleza humana. En realidad, la joven de Beare no quiere que sus 
congéneres no disfruten de sus propios instintos naturales, sino, más bien, no quiere que sufran el dolor y la angustia existencial que el conflicto entre deseo y moral le han infligido a ella.

"The Young Woman of Beare" empieza con dos estrofas que establecen los dos campos de batalla: sexo y oración. En la primera tenemos, por un lado, a la gente temerosa de Dios que va corriendo a rezar a la Iglesia; por el otro, caballeros a galope procedentes de de Burgo $^{19}$ que se dirigen a la casa de la protagonista. El contraste entre la sociedad y la voz del deseo simbolizada por la joven está bien diferenciado. Denman hace hincapié en la misma idea: "the sensual woman rejoicing in sexual fulfilment, and her society made up of figures crowding anonymously to the bleak self-denying rituals of the church" (68). En la segunda estrofa, nos encontramos con la protagonista en su casa, recostada sobre cojines de seda, esperando quizás a algún visitante, y disfrutando de los pensamientos eróticos que le invaden durante el sueño:

Half clad in silken piles

I lie upon a hot cheek

Half in dream I lie there

Until bad thoughts have bloomed

In flushes of desire.

Drowsy with indulgence,

I please a secret eye

That opens at the Judgement. (13-20)

\footnotetext{
${ }^{19}$ También "de Burgh". Se refiere a una de las más importantes familias activas durante la primera oleada de asentamiento Normando en Irlanda en el siglo XII. Se mezclaron con los irlandeses gaéli$\cos$ y formaron una fuerza poderosa en la Irlanda anterior a la Reforma (cf. Maxton, 214).
} 
Son imágenes que evocan comodidad, bienestar y riquéza, y que contrastan con la oscuridad que rodeaba a esas figuras anónimas que huidizamente se apresuraban a rezar: "Through lane or black archway / The praying people hurry" (1-2). Pero en las últimas líneas, Clarke introduce una nota discordante, enigmática y ambigua que explica Harmon,

The 'secret eye' that she pleases includes what the eye can see under closed lids, in fantasy, and what it sees when conscience asserts itself. ... The Last 'Judgement' is also ambiguous in the context, since it involves a final awakening to the reality of sin and that reality contrasts with the 'dream'. (AC 69-70)

Nuestra protagonista continúa en las tres estrofas siguientes afirmando su sexualidad, sintiéndose orgullosa de ella. Sabe muy bien que es una tentación para los hombres, y abiertamente plantea su desafío a la Iglesia: "Although the clergy pray, / I triumph in a dream" (23-24). Ella es la misma tentación que acosaba la conciencia del eremita de "Celibacy", y la que ahora hostiga las conciencias de jóvenes esposas cuyos maridos se revuelven en sueños anhelando tocar su cuerpo: "Their husbands turn at midnight, / And covet in a dream / The touching of my flesh" (36-38).

En las dos estrofas siguientes, según Schirmer las más eróticas en toda la poesía de Clarke (PAC 37), la joven de Beare, postrada medio desnuda entre sus cojines de seda - "Half clad in silken piles"-, rememora o imagina la seducción de un capitán que calzaba grandes botas y que dejó caer una bolsa con relucientes monedas de plata sobre su regazo: 
Heavily on his elbow,

He turns from a caress

To see - as my arms open-

The red spurs of my breast.

I draw fair pleats around me

And stay his eye at pleasure,

Show but a white knee-cap

Or an immodest smile-

Until his sudden hand

Has dared the silks that bind me. (51-60)

See! See, as from a lathe

My polished body turning!

$\mathrm{He}$ bares me at the waist

And now blue clothes uncurl

Upon white haunch. I let

The last bright stitch fall down

For him as I lean back,

Straining with longer arms

Above my head to snap

The silver knots of sleep. (61-70)

Poesía directa, sin ambigüedades, sin oscuridades, completamente diáfana, con una técnica casi cinematográfica acentuada por la repetición del verbo "see". La joven de Beare, la voz del deseo, manipula los sentidos de su amante y conduce lentamente su mirada - y Clarke la del lector - hacia "the red spurs of my breast", "fair pleats", "white knee-cap", “immodest smile”. El capitán toma las riendas de la escena y la despoja de su ropa, pero ella sigue con su juego visual: "See! 
See...", y antes de entregarse a su amante chasquea los' dedos para alejar al sueño que rompería el clímax de su aventura. Y no sólo domina toda la escena un fuerte deseo de ver, de mirar, de voyeurism - ella está orgullosa de su cuerpo y del poder de seducción que emana de él - sino que una cierta complicidad por parte de Clarke hace que el lector comparta también "the captain's and the woman's lust" (Roscelli 58). Pero después del placer, viene la culpa, el pecado, el posterior arrepentimiento. Su conciencia despierta a la realidad y se da cuenta de que ha estado haciendo lo mismo que se permite en el matrimonio, solo que ella se encuentra fuera de los límites marcados por las estrictas reglas eclesiásticas:

Together in the dark-

Sin-fast-we can enjoy

What is allowed in marriage.

The jingle of that coin

Is still the same, though stolen:

But are they not unthrifty,

Who spend it in a shame

That brings ill and repentance,

When they might pinch and save

Themselves in lawful pleasure? (71-80)

Nuestra joven heroína parece estar haciendo apología del matrimonio, y es consciente de que el amor ilícito sólo consigue crear un sentido de culpabilidad. Al darse cuenta de su pecado, el tono de su monólogo adopta un matiz didáctico y advierte a las jóvenes de que se alejen de la tentación: "Young girls, keep from dance-hall / And dark side of the road" (81-82), porque lo único que van a conseguir es una mala reputación como ella - “And got a bad name / In Beare” (86- 
87) - y un complejo de culpabilidad que evitará que sean felices. Pero en seguida cambia el tono, y continúa relatando sus aventuras amorosas. En una se va con un marinero y amanece recostada junto a una barca bajo la mirada inquisitiva de los hombres que la despiertan; en otra, se fuga con un tal MacWilliam ${ }^{20}$, que la lleva aun bosque donde ella "Unknown there to the clergy, / I stayed with him to sin" (126-127).

La joven de Beare es consciente de que está actuando en contra de la moral establecida, y aunque parece disfrutar de ello, vuelve a adoptar el tono didáctico y moralizador para aconsejar a las jóvenes que sean modestas y estrictas en su forma de vestir: ella está condenada a la juventud y a un deseo que no cesa:

It is my grief that time

Cannot appease my hunger;

I flourish where desire is

And still, still I am young. (137-140)

Como lectores, nos damos cuenta de que el tono moralizador de nuestra heroína se disuelve rápidamente entre el regocijo sexual de sus aventuras amorosas, que son, en definitiva, el foco de atención del poema. Después de describir sus experiencias, la joven de Beare se sigue sintiendo orgullosa de su sensualidad y, sobre todo, de su poder:

I am the dark temptation /

Men know - and shining orders

Of clergy have condemned me.

I fear, alone, that lords

30 “MacWilliam” es el nombre de otra poderosa facción política (Maxton 215). 


\section{Of diocese are coped}

With gold, their staven hands

Upraised again to save

All those I have corrupted. (191-198)

En palabras de Schirmer, "the power of her feelings, and of sexuality, is great, but so is that of the church opposing her and what she represents" (PAC 40). Al igual que Gormlai, la joven de Beare teme a los dignatarios de la Iglesia: "I fear, lost and too late, / The prelates of the Church" (199-200), pero sabe que su poder no dejará reposar tranquilas las conciencias de quienes la han conocido.

El poema funciona en dos niveles. Por un lado vemos que la joven de Beare se debate entre ser fiel en el matrimonio e infiel fuera de él; entre ser atractiva y pecadora; entre su propio deseo que no puede apaciguar y la moral estricta de la Iglesia, conflictos que, por otra parte, quedan sin resolver. Creemos, no obstante, que Clarke inclina la balanza a favor de la propia naturaleza humana. Como hemos apuntado anteriormente, el poema se centra en mostrar imágenes y relatar aventuras eróticas, y deja la moral cristiana en los márgenes de la conciencia de la joven. La protagonista la tiene en cuenta, por supuesto, pero no ignora que su poder puede competir con el de la Iglesia. Tanto Gormlai como la joven de Beare, aunque acosadas por la misma ortodoxia cristiana, seguirán dejándose llevar por sus instintos naturales. Ambas son conscientes del poder de la Iglesia, pero también del poder de los instintos naturales del hombre. Gormlai, como dijimos al principio, representa el amor humano, y la joven de Beare el deseo erótico. Creemos que, en cierto modo, las dos se complementan y lo que plantea Clarke es que tanto la una 
como la otra sienten que no podrán ser libres hasta que se despojen del enorme peso de culpabilidad que la Iglesia ha depositado sobre sus conciencias. Para Harmon, las dos heroínas de estos dos poemas son víctimas de las decisiones de otros, víctimas de su propia naturaleza humana, y víctimas de un riguroso dogma eclesiástico ( $A C$ 72).

Por otro lado, vemos como "Women, obey the mission - / Be modest in your clothes" junto con "dance-hall" son anacronismos deliberados que le sirven a Clarke como correlatos históricos para comentar el feroz puritanismo de la Iglesia Católica durante su época, y para expresar nuevamente cómo el conflicto de la joven de Beare es el mismo que el del eremita y el de Gormlai, y, en definitiva, el mismo que el de todo el pueblo irlandés.

Aunque parece que Clarke no puede resolver el conflicto entre la carne y el espíritu, lo que sí deja claro, o así lo entendemos, es que los deseos naturales tanto del hombre como de la mujer son más fuertes que cualquier ortodoxia moral o religiosa que se imponga a la sociedad, y si no, recordemos que a pesar de sus flagelaciones y de su huida al lago para esconderse ente los juncos, a nuestro célibe eremita le era imposible escapar de la tentación carnal que le acosaba a todas horas, y que en definitiva era su propia sexualidad, su propia naturaleza, la que se rebelaba contra sus ataduras religiosas. 
"The Young Woman of Beare" podría situarse en cualquier época, pero las referencias a los hombres de Ormond ${ }^{21}$, la banda de Geraldine ${ }^{22}$, y el Presidente de Munster $^{23}$, lo sitúan en el periodo que comprende los años 1500 a 1700 . Quizás Clarke no lo hiciese a propósito, pero estas referencias funcionan adecuadamiente como transición de unos poemas enmarcados en la temprana Edad Media a otros situados al final de esta época. Asimismo habrá un ligero cambio temático: se abandona el conflicto entre la libertad sexual humana y las imposiciones de la Iglesia por otro no menos importante: el conflicto político, Irlanda versus Inglaterra, o, Catolicismo versus Protestantismo.

Pilgrimage and Other Poems contiene tres aislings, tres poemas visionarios, de lo cuales "The Marriage Night" y "Aisling" tratan del conflicto político entre Irlanda e Inglaterra, y el otro, "The Wandering Men", retoma el conflicto con el que empieza el poemario: paganismo y cristianismo. "The Marriage Night" (171172) sumerge al lector en la noche previa a la batalla de Kinsale. Como ya dijimos anteriormente, existía la creencia de que el señor gaélico se casaba metafóricamente con la tierra para garantizar la fertilidad de su territorio. En este caso, tenemos a los condes gaélicos casándose con una bella mujer que representa a la Irlan-

\footnotetext{
${ }^{21}$ Nombre de una importante y poderosa familia Anglo-Normanda. Su nombre deriva del cargo de un antepasado, Theobald Walter, mayordomo (Butler) en la casa del príncipe John, a quien acompañó en 1185. El título de conde fue concedido en 1329. Esta familia sufrió numerosos contratiempos a lo largo de la historia. Su dominio terminó con la ejecución de James, $5^{\circ}$ conde de Ormond después de la batalla de Towton en 1461. Sin embargo, mantuvieron los títulos hasta el siglo XIX (The Oxford Companion to Irish History 416).

" "Geraldines" es un término usado para describir a la familia de los Fitzgerald, condes de Desmond y de Kildare durante el periodo medieval y moderno de Irlanda (The Oxford Companion to Irish History 221).

${ }^{23}$ El Presidente de Munster al que se refiere el poema es Sir John Perrot (Harmon, AC 70).
} 
da católica. Pero es conveniente hacer un breve apunte del devenir político de la isla hasta la fatídica batalla de Kinsale para situar el poema en su contexto.

Durante el siglo XVI, Irlanda experimentó una serie de cambios, tanto en el terreno político como en el religioso, que sin duda alguna serían decisivos en er rumbo que tomaría la isla durante la Edad Moderna. El este y sudoeste de la isla estaban poblados por descendientes de Anglo-normandos, conocidos como "Old English", y leales a la corona británica. Éstos defendían sus intereses contra los ataques gaélicos y tenían un alto nivel de militarización; sin embargo, siempre fueron más leales a sus señores que a los propios representantes del rey. Dentro de estos, había dos familias importantes, la de los Fitzgerald de Kildare y la de los Butler de Ormond, y cada una quería ser la familia protectora de los intereses ingleses. Hubo rivalidad, pero al final ganó la familia de los Fitzgerald, que pactó con los "chieftains" gaélicos.

Esta delegación de poderes demostraba el poco interés que tenía Inglaterra por la isla antes de 1534. A partir de este año, se formaron facciones políticas, que hicieron que el poder se monopolizara por condados: Kildare, Ormond, Desmond (en la provincia de Munster), lo que contribuyó a que el poder central fuese cada vez más débil. Aprovechándose de esta parálisis política, la Iglesia Católica fue modelando la isla según sus intereses, de forma que los "Old English" y algunas órdenes religiosas ${ }^{24}$ se opusieron a las reformas de Enrique VIII. Los "Old English" se negaron a participar en los servicios de la Iglesia del Estado, lo que

\footnotetext{
${ }^{24}$ Como por ejemplo los Observant Friars que eran frailes mendicantes de las áreas gaélicas.
} 
obligó a Enrique VIII a imponer la aceptación de la autoridad del monarca en asuntos espirituales a toda aquella persona que ocupara cargos en la administración, lo cual creó un estado de malestar entre la población de los “Old English".

La mayor resistencia al gobierno central la opuso la familia de los Fitżgerald de Kildare, que acabaron siendo sustituidos como representantes de la corona por el rey. En respuesta a esta oposición, el rey mandó confiscar sus tierras y pasar por Ias armas a todos los varones, salvándose solo un niño, hijo del noveno conde de Kildare. A pesar de esto, los partidarios de la familia de los Fitzgerald, que querían la restauración del título al heredero legítimo y la devolución de sus tierras, frecuentemente atacaban a los ingleses y hacían incursiones en sus territorios - a menudo traspasando los límites del $\mathrm{Pale}^{25}-$, lo que obligó a la militarización del territorio.

La corona fue así esforzándose en lograr la estabilidad dentro de las zonas gaélicas. Isabel I decidió dividir la gran provincia del Ulster para reducir su poder. Se acordó que el gobierno de una de las partes cayera en manos de Hugh O' $\mathrm{Neill}^{26}$, con cuya ambición no contaron. Éste reclamaba el condado de Tyrone, y lo que empezó como un pequeño conflicto, se convirtió en la Guerra de los Nueve Años ${ }^{27}$.

\footnotetext{
${ }^{35}$ Literalmente "La empalizada. Territorio circundante de la ciudad de Dublín que desde principios del siglo XIV hasta finales del XVI estuvo bajo la jurisdicción efectiva de la Corona inglesa. ... Su extensión fluctuaba en función de la supremacía inglesa sobre la isla, si bien nunca se extendió más allá de la provincia de Leinster" (Hurtley et al. 250).

${ }^{36}$ Este era hijo de Matthew O'Neill, barón de Dungannon. Durante el gobiemo del conde de Sussex, un señor gaélico, Shane O'Neill, empezó a dar muestras de rebeldía y de insubordinación, y reclamaba el condado de Tyrone, lo cual hizo que lo sustituyeran por Matthew O'Neill y sus hijos. Shane asesinaría más tarde a Matthew (Cf. The Oxford Companion to Irish History 412).

${ }^{27}$ De Abril 1593 a Marzo de 1603. También se la conoce como la rebelión de Tyrone, debido al principal antagonista en el conflicto, Hugh O'Neill, segundo conde de Tyrone. La guerra terminó con la batalla de Mellifont en la que O'Neill se rindió. La victoria dio por primera vez a Inglaterra el
} 
O’Neill pidió ayuda al rey Felipe III de España, que envió 4.000 hombres que se establecieron en Kinsale. La reina Isabel consideró esto como un desafío sin precedentes y envió una fuerte tropa para solucionar el conflicto. La batalla de Kinsale, librada la Nochebuena de 1601, dio la victoria a los ingleses. En 1603, O'Neil؟ se rindió en Mellifont, y en 1607, O'Neill y Rory O'Donnell ${ }^{28}$, abandonaron la isla y se refugiaron en el continente. Esta huida histórica se conoce como "The Flight of the Earls", y marca el comienzo del derrumbamiento de la civilización Gaélica y del viejo orden ${ }^{29}$.

Pero antes de continuar con el poema, es importante observar que la másc ara que adopta Clarke en los poemas que abarcan estos siglos es la del bardo gaéli$\mathrm{co}^{30}$. El poeta más importante del siglo XVII fue Egan O'Rahilly (1675-1729), que compuso el primer aisling ${ }^{31}$, que era un tipo de poema en el que una mujer se le aparecía al poeta, lamentando la actual condición del país y anhelando la vuelta de los Estuardo. Esta indefensa mujer, normalmente rubia, llamada spéirbhean o "sky-woman", “would only recover her happiness when a young liberator would come to her defence" (Kiberd, Inventing Ireland 18), y según una tradición nativa, se la ha identificado indistintamente con la mítica Deirdre of the Sorrows, la reina

control completo de la isla desde la invasión Anglo-Normanda (The Oxford Companion to Irish History 388).

${ }^{28}$ Los condes gaélicos que huyeron del país fueron: Hugh O'Neill, conde de Tyrone, Rory O'Donnell, conde de Tyrconnell. Les acompañaron Cúchonnacht Maguire, señor de Fermanagh, y sus seguidores. Salieron de Rathmullen, Co. Donegal, el 4 de Septiembre de 1607 (The Oxford Companion to Irish History 201).

${ }^{\Im}$ Según Vivian Mercier, la destrucción del sistema gaélico lo empezó Isabel I, lo completaron parcialmente Jacobo I y Cromwell, y quedó totalmente destruido con Guillermo III (ICT 128)

${ }^{30} \mathrm{~L}$ os bardos eran poetas profesionales que se encontraban en todas las sociedades celtas. Componían alabanzas para sus señores o sátiras contra los enemigos de sus patronos.

${ }^{31}$ Estos poemas los escribían especialmente los poetas de Munster, inspirados por un sueño de recuperación nacional (McMinn 15). 
guerrera Maeve, o la reina pirata Grace O'Malley ${ }^{32}$. En esta forma visionaria de poesía se combinan de forma inusual lo político, lo religioso y lo erótico: la esperanza en la vuelta del Pretendiente estuardo, la alegoría religiosa, y la presencia de una bella mujer. Daniel Corkery, en The Hidden Ireland, sitúa estas composiciones dentro de la tradición de la poesía Jacobita, y explica el arte que estos poemas encierran:

...The word 'Aisling' means vision; and the vision the poet always sees is the spirit of Ireland as a majestic and radiant maiden.... Ireland is in all the 'aisling' poems; and the only lines in them that strike fire from us are those of her sorrow. (126-30)

Aunque se siguió escribiendo literatura en gaélico durante el siglo XVII, después de la derrota de los Estuardo en Culloden ${ }^{33}$ en 1746, el aisling dejó de escribirse debido a su falta de realidad ${ }^{34}$; además, este tipo de composición poética, a pesar de su renombre por su dramatismo y virtuosidad técnica, era la obra de una elite, comprensible sólo para unos pocos. Debido a su estudiado formalismo, a menudo tenía un carácter ceremonial, una forma ritualizada de ira y de pesar (Macminn 26).

Clarke descubrió esta forma poética en compañía de F.R. Higgins cuando hojeaban el libro ya mencionado de Daniel Corkery, y la va a usar para mantenerse

\footnotetext{
32 También conocida con el alias de Granuaile. Es una legendaria pirata-reina de Connaucht, celebrada en la tradición popular como heroína nacional (Cf. The Oxford Companion to Irish History 410).

${ }^{33}$ En Julio de 1745, el hijo del Pretendiente, Jacobo III, juntó un ejército en Escocia y se dirigió hacia el sur. Sin embargo, tuvieron que retirarse y fueron derrotados en Culloden, el 16 de Abril de 1746.

${ }^{34}$ En el siglo XX, sin embargo, poetas como Paul Muldoon o Eavan Boland han revivido este tipo de poema, con lo que no ha de pensarse que esta forma poética quedara enterrada en el siglo XVIII, o formara parte de un pasado caduco.
} 
fiel a la tradición gaélica - especialmente en cuanto a métrica y rima se refiere - y como metáfora histórica.

The mode of the Aisling or Vision poem tempted us to experiment in forgotten forms, for we had revolted against the inordinate claims of. nineteenth century symbolism. (Clarke, PIM 42)

El tono de desesperanza y de tristeza de los bardos gaélicos ante una Irlanda dominada por las fuerzas protestantes es el que transmite Clarke ante la Irlanda que contemplan sus ojos. Aunque no hay una referencia exacta a la época, creemos que cualquiera de los terribles acontecimientos que asolaron Irlanda desde el levantamiento de Pascua de 1916 hasta el final de la cruenta Guerra Civil podría considerarse el correlato de la Irlanda de después de Kinsale.

Según Harmon, "The Marriage Night" es un poema visionario porque "[it] creates an imaginary wedding between a beautiful woman and the great earls, Hugh O'Neill and Red Hugh O'Donnell' ( $A C$ 73). La nota de Clarke sobre el poema confirma la historicidad del poema: "The religious Confederacy of Powers in the seventeenth century sustained defeat at Kinsale but the Gaelic Poets still hoped that the European armies of the Counter Reformation would be victorious" (Later Poems 22-3). El poema recrea el grado de esplendor y poder de las fuerzas gaélicas, la felicidad de la mujer - que simboliza Irlanda - el día de su boda con los condes gaélicos, y la esperanza puesta por los señores gaélicos en las fuerzas españolas:

The morning she rode down

Where topsails, that had brought

A blessing from the Pope, 
Were scrolled in early water:

Such light was on her cheekbone

And chin - who would not praise

In holy courts of Europe

The wonder of our days? (9-16)

Sin embargo, a pesar de la alegría que irradiaba la celebración - "They got up at the gospel. / In joy the clergy prayed" (20-21) -, la última estrofa del poema rompe todas las expectativas que se habían creado anteriormente, y la mujer, es decir, Irlanda, tiene que volver a "dormir" con los "herejes" protestantes después de la derrota. El tono de tristeza y abatimiento antes las frustradas esperanzas de los católicos domina la estrofa:

But deceit of smoke

And fire, the spoilers came:

Tower and unmortar'd wall broke

Rich flight to street and gate.

$\mathrm{O}$ she has curbed her bright head

Upon the chancel rail

With shame, and by her side

Those heretics have lain. (31-38)

En palabras de Tapping, estas estrofas muestran el amor de Clarke por Irlanda, y su "idealism is emphatic acceptance and willed surrender to mistress and country. When both fail his imagination's demands, a disillusioned faith remains" (66).

Y la misma desilusión que generó la derrota de Kinsale, la encontramos en "Aisling" (173-175), poema que sigue las convenciones del aisling de los poetas 
del siglo XVIII: el poeta encuentra a la "sky-woman", que personifica a Irlanda, junto a un arroyo y la describe con elegantes detalles eróticos:

Coil of her hair, in cluster and ringlet

Had brightened round her forehead and those curls-

Closer than she could bind them on a finger-

Were changing in gleam and glitter. $\mathrm{O}$ she turned

So gracefully aside, I thought her clothes

Were flame and shadow while she slowly walked,

Or that each breast was proud because it rode

The cold air as the wave stayed by the swan. (9-16)

El poeta interroga a la mujer para saber quién es, y cita varios nombres mitológicos

o clásicos como posibilidad - Geraldine, a Greek Woman, Niav. Una de las convenciones del aisling era la de que la mujer entregara un mensaje político al poeta; sin embargo, ésta no responde ni entrega mensaje alguno. El poema de Clarke carece de mensaje, y en su lugar nos encontramos con una serie de preguntas que apenas quedan contestadas:

'But from what bay, uneasy with a shipping

Breeze, have you come?' I said ' $\mathrm{O}$ do you cross

The blue thread and the crimson on the framework,

At darkfall in a house where the nobles throng

And the slow oil climbs up into the flame?'. (28-32)

La única respuesta que ofrece es "Black and fair strangers leave upon the oar / and there is peace" (33-34), que se refiere a las tropas españolas cuando abandonaron Irlanda después de la derrota en Kinsale. El poema termina con la desaparición de la mujer, y con el poeta preguntándose si se encontrará entre sus "vecinos" y entre 
los de su clase - “...or bide among my own” (44) - o tendrá que vagar por otras tierras, es decir, irse al exilio. Da la sensación de que Clarke está pensando en la Irlanda de después de la Guerra Civil y en una Irlanda de la que el poeta no puede esperar nada excepto desprecio y olvido:

...O must I wander

Without praise, without wine, in rich strange lands?' (45-46)

El tercer y último poema visionario es "The Wandering Men" (177-178), que no estaba incluido en el poemario original sino que fue añadido en la recopilación de 1936. Clarke retoma el viejo conflicto entre cristianismo y paganismo. Se le puede etiquetar como un poema de visión porque en él "the pagan aspects of a christian saint are revealed" (Harmon, $A C$ 74), y porque además sigue las convenciones del género: unos peregrinos se pierden en un bosque y empiezan a rezar hasta que ven el monasterio de Kildare - "the bell-house of Kildare" (8) - en cuya puerta se les aparece Santa Brígida, la santa de Kildare, que fundó el monasterio en la década de los años 20 del siglo $\mathrm{VI}^{35}$. Verso a verso se ve la transformación de cristiana a pagana que experimenta la abadesa del convento. Así, en la cuarta estrofa,

And all that night I was aware

Of shapes no priest can see,

The centaur at a house of prayer

The sceptred strangers from th East

\footnotetext{
${ }^{35}$ Brígida es una figura que pertenece más a la leyenda que a la historia, $\mathrm{y}$ hay fuentes del siglo $\mathrm{X}$ que sugieren que el culto a este personaje se originó como cristianización de una diosa pagana. Pero su devoción se extendió rápidamente y fue la primera santa irlandesa que se conoció fuera de la isla (The Oxford Companion to Irish History 59).
} 


\section{Confined in dreams we saw again}

How Brigid, while her women slept

Around her, templed by the flame,

Sat in a carven chair. (25-32)

Las imágenes paganas se repiten: "centaur", "sceptred strangers", "templed flames", y "carven chair". Todas, excepto "sceptred strangers", que se refiere a los Tres Reyes Magos, tienen un aroma pagano. Las dos últimas evocan el pasado pagano de la diosa cuando se la adoraba en ritos paganos. El mensaje, convención típica del aisling, está, en nuestra opinión, implícito en el poema: la unión de lo cristiano con lo pagano. Cuando los peregrinos se despiertan, ven que la casa ha desaparecido, pero que no obstante adoraron a esa "sky-woman", lo que confirma la unión entre estas dos formas religiosas. Según Harmon, el poema es una parábola "for the imagination's ability to discover the unknown within the known, the mythical within the christian, the past within the present" (AC 75). Para Tapping, el poema simplemente muestra un ejemplo de la unión entre lo cristiano y lo pagano (69).

Pilgrimage and Other Poems marcaría el fin de una etapa en la vida poética de Clarke, ya que no volvería a escribir poesía hasta la publicación en 1938 de Night and Morning. En este nuevo poemario recoge el viejo conflicto medieval entre la razón y la fe, y lo traslada a su propio campo de batalla interior que, como veremos en el siguiente capítulo, sirve como sinécdoque del conflicto entre el individuo y la religión. Sin embargo, a pesar de los nueve años que transcurren entre los dos trabajos, Pilgrimage and Other Poems contenía ya, en la traducción de un 
viejo poema gaélico, "The Scholar" (162), el tema-embrión de lo que sería Night and Morning: el conflicto entre la razón y la fe.

Este poema había aparecido en el primer drama de Clarke, The Son of Learning (1927), y está basado en un viejo cuento irlandés de la época medieval ${ }^{\$ 6}$. En realidad es un ejercicio de traducción e imitación del estilo gaélico. En los primeros versos vemos que el erudito está feliz con su "knowledge and reason" (2) sin tener obligación alguna con la iglesia, "Paying no dues to the parish" (5). La fe religiosa parece no tener cabida en sus planes, y su indiferencia hacia ella es patente en todo el poema: "He sleeps by a river / Or comes to the stone plain / Where the saints live" (16-18).

Será, sin embargo, en Night and Morning donde Clarke se enfrentará a sus miedos, a su angustia existencial, a su conflicto entre la fe que le fue inculcada y el rechazo de una autoridad que le niega la razón en favor de esa fe que quiere controlar su atormentada conciencia.

\footnotetext{
${ }^{36}$ Según Clarke, en sus notas a Collected Poems (1936), dice: "This comedy is a tribute to a medieval Irish tale, Goliardic in type, called Aisling Meic Conglinne (The Vision of Mac Conglinne), and is meant to be acted in high spirits" (316).
} 


$$
\text { - }
$$

III. LA RAZÓN Y LA FE 
$-$ 


\section{III.1 El conflicto fe $v s$ razón.}

Fides quaerens intellectum ${ }^{\prime}$

Nueve años después de que se publicara Pilgrimage and Other Poems, apareció el poemario Night and Morning, considerado por la mayoría de loš críticos como una de sus mejores obras: "Anyone familiar with the entire work of Austin Clarke must agree that, apart from the volumes of collected poems or plays, extant or to come, this is one of his two or three finest books" (Mercier, "Mortal" 91); "But this volume of dozen poems is, I believe, Clarke's best" (Halpern, AC 61). Sin embargo, el poemario es denso y difícil, y sus versos rezuman imágenes que exigen un esfuerzo extraordinario por parte del lector. Muchos críticos han puesto de relieve la oscuridad que envuelve parte de la poesía de Clarke. George B. Saul afirma que "The whole book is opaque with an intellectualism that seems to be seeking difficult images and contorted statement ... with results sometimes puzzling to the point of bafflement" ("Poetry" 32). Para Roscelli ("Private" 56),

The revival of interest in the poetry of Austin Clarke, occasioned largely by the 1961 publication of his Later Poems, has brought into rather sharp focus one of the most difficult problems with which the literary critic has to wrestle, namely, the relative obscurity of much contemporary poetry.

Pero el mismo título del poema ya preconiza cierta dificultad en los versos que contiene; de hecho, la luz y oscuridad de los poemas de Night and Morning

\footnotetext{
${ }^{1}$ Faith seeking understanding.
} 
funcionan como imágenes íntimamente asociadas a las luchas de conciencia del autor: la luz simbolizará la razón y la oscuridad, la religión católica.

Aparte de algunas diferencias estilísticas - voz poética más personal y austera; ausencia de descripciones paisajísticas; léxico más intelectüal y abstracto- Night and Morning sigue explorando el conflicto entre la religión y el individuo. Si Pilgrimage and Other Poems se centraba en la oposición de la carne y el espíritu, de la sexualidad y el ascetismo monástico, que servía a su vez de correlato histórico para acercarse a la realidad de la Irlanda contemporánea, este nuevo poemario toma como metáfora el conflicto entre la razón y la fe para mostrar la imposibilidad del poeta de reconciliar su fe con su intelecto. La oposición entre la filosofía humanitaria de Clarke y los rectos dogmas de la Iglesia Católica impregna los versos de esta obra:

Between a view of man as inherently capable of great achievement and entitled to the pleasures of secular life, and a view of man as helpless without the grace of God and in need of severe moral discipline. (Schirmer, PAC 44)

Clarke sigue luchando contra la filosofía religiosa que le inculcaron en la infancia: "Having been trained by Jesuits from the age of seven, I am still unable to hold opinions with certainty and envy those who can trust in private judgement" (Clarke, TRBC 13).

Night and Morning puede asimismo definirse como un poemario de corte escolástico porque utiliza en sus argumentos el mismo debate que mantuvo ocupados a los grandes filósofos de la Edad Media — el de la fe y la razón-, los 
cuales se esforzaron en tratar de demostrar que el Cristianismo no era incompatible con lo que se podía demostrar mediante la razón. Clarke es consciente de esta dicotomía y, como veremos a lo largo de este capítulo, estructura sus poemas en función de ella. Pero el conflicto es más complejo de lo que parece a primera vista.Para Clarke el problema no radica en las abstracciones "fe" y "razón" mismas, sino en la lucha que plantean esa "fe" y esa "razón" individualmente. Así, antes de alcanzar la madurez intelectual, el individuo hereda la carga que representa la mortalidad y su propia naturaleza pecaminosa: debe llevar consigo la responsabilidad de la muerte y el sufrimiento de Cristo. Lo que le ocurre al individuo es que,

When he tries to act in accordance with what he believes, he is liable to come into conflict with the laws of the Church; when he tries to act in accordance with his instincts, particularly his sexual feelings, he is also liable to come into conflict with clerical prohibitions. (Harmon, AC 77-78)

Este conflicto aparece en dos tipos de poemas: confesionales, en los que Clarke explora su atormentada sensibilidad, y satíricos, pequeñas muestras anticipatorias de lo que será su poesía a partir de 1955.

El primer poema con que nos encontramos al abrir este poemario es el homónimo "Night and Morning" (181-182), en el que se celebra el orgullo y el intelecto del hombre, y donde el sufrimiento de Cristo se usa como imagen intelectual. Recordemos que el Cristianismo se basa en un misterio trinitario: la encarnación, la crucifixión, y la resurrección de Cristo, que murió para expiar los 
pecados de la humanidad. Los versos de Clarke no son un alegato contra la Iglesia sino más bien una muestra de respeto hacia los logros de épocas pasadas en las que la fe y la razón no se enfrentaban entre sí de forma tan contundente. Clarke no toma partido por ninguna, porque es consciente de la imposibilidad de conciliar ambas abstracciones. Para Mercier, y también para nosotros como lectores, fue una suerte que Clarke no pudiera encontrar una solución, ya que de haber sido así, "[he] might have ceased to be a poet" ("Mortal" 91).

I know the injured pride of sleep, The strippers at the mocking-post, The insult in the house of Caesar And every moment that can hold In brief the miserable act

Of centuries - and the tormented soul, Changing confession to despair, Must wear a borrowed robe. (1-9)

El pronombre personal con el que da comienzo el poema nos advierte de que esta vez no hay máscaras detrás de las cuales puede refugiarse el poeta, como las había en Pilgrimage and Other Poems, sino que es el propio autor en primera persona quien habla con conocimiento y experiencia. "I know" aporta sentido de autoridad y seguridad sobre lo que viene después, las imágenes que se refieren a los momentos anteriores a la crucifixión de Cristo; la escena en la que Pilatos se lava las manos, y aquella en la que los soldados se burlan de Cristo mientras le despojan de sus ropas, que sirve no sólo para dejarle desnudo físicamente sino para despojarle de toda dignidad. 
Estos dos hechos junto con todos aquellos que condujeron a Cristo a su muerte, y que Clarke define como "the miserable act / of Centuries" (5-6), son los que atormentan al poeta en sueños que se convierten en pesadillas de las que no puede sentirse orgulloso. Pero no son solamente estas acciones las que le quitan er sueño. El poeta sabe lo que significa la muerte de Cristo, pero a menos que crea en ella, no podrá compartir la recompensa, es decir, la vida eterna. La agonía del poeta se convierte, por extensión, en la de Cristo, y la confesión, que es un acto de fe en la piedad de Cristo, se transforma en un acto de desesperación. Su falta de fe hace que se sienta desnudo, tan desnudo como Cristo cuando lo despojaron de sus vestimentas, lo cual aboca indefectiblemente al poeta a la pérdida de su propia dignidad y le obliga a ponerse una túnica prestada, con la que finge participar en lo que no cree.

La segunda estrofa nos hace partícipes de la misa a la que está asistiendo el protagonista del poema, y el penúltimo verso sitúa al lector cronológicamente: todo parece indicar que es el día uno de noviembre, día de todos los santos - “All saints have had their day at last" (17) - aunque como indica Maxton (232), el verso recuerda subversivamente el proverbio popular, "Every dog must have his day", que aunque sea cierto, nosotros no creemos que esa fuera la intención de Clarke. La estrofa sigue temáticamente a la anterior: si el poeta no comparte las consecuencias de la expiación de Cristo, entonces los sacramentos no tienen ningún sentido para él: 
Morning has moved the dreadful candle,

Appointed shadows cross the nave;

Unlocked by the secular hand,

The very elements remain

Appearances upon the altar.

Adoring priest has turned his back

Of gold upon the congregation.

All saints have had their day at last,

But thought still lives in pain. (10-18)

El elemento clave alrededor del cual gira la estrofa es el sacramento de la comunión. El poeta no puede creer en la transubstanciación, mediante la cual el pan y el vino se convierten en el cuerpo y la sangre de Cristo, lo que sume al poeta en la angustia existencial que provoca el conflicto entre su intelecto y su fe: "But thought still lives in pain". Aparte de su interpretación literal, el léxico que utiliza Clarke es susceptible de otras interpretaciones. La primera palabra que llama la atención del lector es el adjetivo "dreadful", que modifica a "candle". Según Maxton, "the 'dreadful candle' may be taken as the sanctuary lamp which burns only when the consecrated host is present” (232). ¿Puede una vela ser espantosa, terrible, o simplemente atroz? Según la liturgia católica, la vela alumbra solamente cuando se ha realizado la transubstanciación, y por una simple extrapolación semántica, "dreadful" adjetiva el momento mismo que para el observador - Clarke en este caso- representa ese instante terrible en el que su fue choca frontalmente con su razón. Cuando entra la luz de la mañana, parece disminuir el efecto del milagro al arrojar luz sobre la vela. Clarke juega constantemente con la luz y la 
oscuridad. La luz solar - fuerte y brillante - representa a su intelecto, mientras que la débil fe del poeta está representada por la tenue luz de una vela que no puede competir con los raudales de luz que entran por las cristaleras de la iglesia.

Esta luz solar a su vez ilumina a otros sacerdotes - "appointed shadows"-,que han sido nombrados o designados para el oficio de la misa. El adjetivo "secular", que modifica a la sinecdóquica "hand", tiene dos posibles significados que contribuyen a mantener la oposición que sustenta todo el poema. Uno es el que se deriva de "a secular priest", es decir, aquél que no pertenece a orden alguna; el otro es el opuesto a divina, $y$, por tanto, solamente funcional.

"Elements" y "Appearances" se refieren al pan y al vino antes y después de la transubstanciación. Según Maxton, "Transubstantiation is explained in the following terms - "the Eucharist is the true Body and Blood of Christ under the appearance of bread and wine" (232), por lo que Clarke está usando los dos significados de la palabra "appearances": el sentido técnico que hemos visto, y el idiomático de simples apariencias. El sacerdote, "adoring" en el sentido de que adora y ama a Cristo, tiene su dorada espalda vuelta hacia los feligreses - hacia el este, hacia el lugar de la resurrección-, lo cual era una práctica habitual que el Concilio Vaticano II se encargó de cambiar ${ }^{2}$. Tapping lo interpreta diciendo que el verdadero motivo es el de representar a la Iglesia absorta en su ritual, indiferente a las verdaderas necesidades de la gente ( $A C$ 167).

\footnotetext{
${ }^{2}$, Esta práctica se cambió en el Concilio Vaticano II, en 1963, de forma que durante la liturgia el sacerdote permanece mirando a la gente (Maxton 232).
} 
Clarke se identifica en las dos estrofas siguientes con los escolásticos ${ }^{3}$, que tuvieron que sufrir por su lealtad a la libertad de pensamiento y cuyos esfuerzos fueron en vano, al tener que ceder ante la autoridad de la Iglesia:

How many councils and decrees

Have perished in the simple prayer

That gave obedience to the knee; (19-21)

Igual que la Iglesia conmemora el día de todos los santos, Clarke recuerda aquellos mártires olvidados que sufrieron mentalmente por "nosotros", y que además rejuvenecieron el latín que, como dijo Clarke en un artículo, "Even when it was dead, came to life as the language of the soul"4:

Forgotten as the minds that bled

For us, the miracle that raised

A language from the dead. (25-27)

Clarke usa a menudo el correlato histórico para comentar los sucesos de su propia época. La última estrofa de "Night and Morning" nos devuelve al mundo medieval, en el que la separación entre razón y fe no era tan grande como parecía serlo para la Iglesia del sigo XX:

\footnotetext{
${ }^{3}$ La filosofía de los escolásticos medievales se caracterizaba por el predominio de la idea religiosa, y orientaron sus especulaciones filosóficas hacia la Divinidad. El problema más elevado y trascendental de todos los que se encarga la filosofía era para ellos el conocimiento de la naturaleza divina. Intentaron resolver los insondables abismos de la divinidad mediante el intelecto. Su ambición era la de aclarar los misterios sobrenaturales, pero algunos escolásticos pecaron de querer sondear más de lo que permite la razón. Sin embargo, para la mayoría era axiomática la armonía entre la fe y la razón, y cuando los averroístas latinos del siglo XIII quisieron justificar sus proposiciones filosóficas con la afirmación de que podía ser verdad en filosofía lo que era falso en teología, santo Tomás rechazó indignado dicho oposición entre las dos verdades. En general, los escolásticos eran optimistas, y tenían una firme confianza en que la razón dentro de ciertos límites podría alcanzar la verdad, no solo por su fe, sino por su filosofía..

${ }^{4}$ Citado en Maurice Harmon, AC 80.
} 
$\mathrm{O}$ when all Europe was astir

With echo of learned controversy,

The voice of logic led the choir.

Such quality was in all being,

The forks of heaven and this earth

Had met, town-walled, in mortal view

And in the pride that we ignore,

The holy rage of argument,

God was made man once more. (28-36)

Durante la Edad Media los filósofos se mantuvieron ocupados tratando de buscar un punto intermedio entre fe y razón, entre "choir" y "logic", que, según Clarke, vivían en armonía. "Forks of heaven" se refiere a algunas ciudades medievales en las que la iglesia se encontraba en la intersección de dos calles o carreteras principales (cf. Harmon, $A C$ 80; Maxton, 233). La religión de la época medieval se basaba no en una fe anti-racional sino en el poder de la inteligencia del hombre — "the pride that we ignore"-, y el vacío entre la religión y la fe era lo suficientemente pequeño como para unir el cielo y la tierra. Según Schirmer, el poema sugiere una especie de encarnación en la que Dios se hace hombre, y, por tanto, accesible al hombre (PAC 50).

"Night and Morning" es un poema nostálgico, un poema en el que el poeta recuerda una época en la que la razón y la fe coexistían armónicamente, a pesar del debate que ambas provocaron. "Tenebrae"s (183), en cambio, es un poema que

\footnotetext{
${ }^{5}$ Este poema apareció publicado en The London Mercury 35. 210 (1937): 550-551, con el título de "A Song in Lent".
} 
regresa a la Irlanda de Clarke, y conduce al lector a través de los símbolos de la Semana Santa en los días de duelo por la muerte y el sufrimiento de Cristo. Es quizás el poema donde la oposición entre la fe religiosa y la razón humana es más evidente. El título es significativo - tenebrae, del latín "tinieblas"- y ya los primeros versos nos sumergen en esa atmósfera de oscuridad religiosa que envuelve no sólo a este poema sino también a gran parte del poemario:

This is the hour that we must mourn

With tallows on the black triangle,

Night has a napkin deep in fold

To keep the cup; yet who dare pray

If all in reason should be lost

The agony of man betrayed

At every station of the cross? (1-7)

En la Semana Santa católica, se celebran ritos solemnes que conmemoran la pasión, muerte y resurrección de Cristo. El poema se centra en el oficio de Tinieblas ${ }^{6}$ del Viernes Santo. Los cuatro primeros versos exponen meramente la escena de la vigilia: las velas del tenebrario ${ }^{7}$ a punto de apagarse, y un pañuelo doblado que reposa sobre el Cáliz sagrado. La práctica de celebrar este oficio en oscuridad simboliza la ausencia de luz al morir Cristo, y trae a la memoria las tinieblas que en su muerte se extendieron por toda la tierra, y, obviamente, la

\footnotetext{
${ }^{6}$ Son oficios de maitines y laudes durante los tres últimos días de la Semana Santa. Se llaman así porque los oficios nocturnos del Jueves al Viernes Santos se celebraban en la basílica de la Santa Cruz de Jerusalén (Roma) a oscuras con una sola luz que alumbraba al lector, contrastando con las grandes luminarias de la noche del miércoles al Jueves y del Sábado al Domingo de Pascua.

7 Un tenebrario es un "candelabro triangular, con pie muy alto y con quince velas, que se encendían en los oficios de tinieblas de Semana Santa. También hay otras fuentes que indican que el número de velas podría ser de once.
} 
pasión de la crucifixión de Cristo, su sacrificio para salvar a toda la humanidad. También representa la deserción de los apóstoles en el jardín de Gethsemaní, de aquí la costumbre de ir apagando las velas una a una hasta dejar solamente una encendida (cf. Harmon, AC 81; Schirmer, PAC 46), que se guardaba detrás deraltar en señal del entierro de Cristo y reaparecía el domingo de Pascua simbolizando la resurrección.

La pregunta del poema se centra en el dilema que atormenta a Clarke $-\mathrm{y}$ por extensión al hombre moderno- de si debe aceptar la crucifixión como un hecho de fe o, por el contrario, rechazarlo, ya que su razón lo excluye de la salvación que conlleva la muerte y sufrimiento de Cristo. La primera parte del poema recuerda al lector que Cristo murió por los pecados del hombre, quien en cierto sentido traicionó a Cristo; la segunda apunta lo contrario, es decir, que es el hombre el que se siente traicionado al tener que ceder su razón a la religión ( $c f$. Schirmer, $P A C$ 47; Harmon, $A C$ 81). El hombre es una víctima involuntaria que se desespera al recordar la inocencia perdida, el periodo anterior al de tener uso de razón:

O when the forehead is too young,

Those centuries of mortal anguish,

Dabbed by a consecrated thumb

That crumbles into dust, will bring

Despair with all that we can know;

And there is nothing left to sing,

Remembering our innocence. (8-14) 
Ya desde su infancia, al hombre se le recuerda su mórtalidad el Miércoles Santo, primer día de la Cuaresma, cuando el sacerdote toma un poco de ceniza y hace la señal de la cruz en su frente. El conocimiento de la fragilidad humana lleva al poeta a la desesperación y limita su libertad imaginativa: "There is nothing \eft to sing when the horror appears to be inescapable. There is nothing left to sing when one has been expelled from the Eden of childhood by the Church's harsh decrees" (Harmon, $A C$ 81). En otras palabras, Clarke transmite la idea de que la Iglesia Católica cargaba a sus creyentes con problemas de conciencia y conceptos teológicos cuando eran demasiado jóvenes para entenderlos.

El conflicto entre las exigencias de la fe y la razón se dramatiza en la tercera estrofa, que insiste en que la experiencia religiosa no es tan fácil de abandonar. En las primeras líneas, el poeta se compara con Martin Lutero, cuando clavó sus tesis en la puerta de la catedral de Wittenberg como símbolo de integridad intelectual y libertad individual:

I hammer on that common door,

Too frantic in my superstition,

Transfix with nails that I have broken,

The angry notice of the mind.

Close as the thought that suffers him,

The habit every man in time

Must wear beneath his ironed shirt. (15-21) 
La imagen de Clarke clavando a martillazos con sus uñas rotas "the angry notice of the mind", trae a la memoria los clavos ${ }^{8}$ que utilizó Lutero. El estado de ánimo del poeta sale a la superficie a través del léxico - "Hammer", "frantic", "transfix", "angry"- y muestra tanto su desesperación intelectual como su necesidađ espiritual, recalcada especialmente en la palabra "superstition. Porque la verdadera causa de este conflicto interior no consiste exclusivamente en decantarse por la razón o la fe, sino que "[Clarke] is still much attracted, at least partially, to that which his intellect forces him to reject" (Halpern 66). La razón sola no puede luchar contra la eternidad de la pasión de Cristo, la cual se encuentra presente tanto en la vida del poeta como en la de sus lectores cristianos. Clarke se esfuerza en clavar sus "tesis" en la puerta de una religión que prohibe el libre ejercicio de la razón. Como muestran los tres últimos versos, el conflicto no puede resolverse a favor de ninguna de las dos partes porque la necesidad de vida espiritual es una parte integrante de la naturaleza humana. Es decir, parafraseando a Clarke ${ }^{9}, \tan$ cerca está del sufrimiento la razón como la religión, y en cualquier caso, el hombre ha de llevar debajo de sus ropas de seglar (metáfora de las restricciones que le impone la vida) un mismo "hábito"10, el de la mortalidad.

\footnotetext{
${ }^{8}$ Tengamos presente el doble significado de "nail": uña y clavo.

${ }^{9}$ La poesía se caracteriza por la condensación. En Clarke esto es habitual junto con la supresión de verbos auxiliares. Los tres últimos versos quedarian así sin las elipsis: "the thought that suffers him is as close as the habit that every man in time must wear beneath his ironed shirt".

${ }^{10}$ Clarke juega aquí con el doble sentido de "habit", el de ropa llevada por un religioso y el de costumbre.
} 
En la primera estrofa, Clarke rechaza la religión a favor de la razón; en la última, en cambio, no hay tal rechazo y admite que éste es imposible. Acepta, por supuesto, que la razón altera la fe, pero da la espalda a la luz de ese sol que simboliza la razón y que como el verdadero sol no puede iluminar más que la mitad del mundo:

An open mind disturbs the soul,

And in disdain I turn my back

Upon the sun that makes a show

Of half the world, (22-25)

Así, la oscuridad que permanece en la otra mitad, es tan inquietante como la claridad, por lo que el poeta no reconoce las limitaciones de la razón y de la fe; consecuentemente, se ve obligado a rechazar la fe religiosa - "That pain that lives within the past" (26) - , la promesa de la resurrección de Cristo - "The flame sinking upon the spike" (27) - , y las tinieblas que aterrorizan al hombre - "Darkness that man must dread at last" (28). Esa ausencia de luz con que termina el poema y que Clarke rechaza es, en palabras de Schirmer (PAC 47), "no longer merely that of an anti-rational religious faith, but is also the darkness of death and of spiritual despair". En definitiva, el poeta no puede resolver el conflicto que lo atormenta, y cae impotente en un círculo vicioso: incapaz de abrazar la fe, pero atrapado, no obstante, por ella. Solo y sin protección contra el terror a la condenación eterna, Clarke intentará buscar un equilibrio entre ambas fuerzas. 
"No Recompense" (190) es el poema donde Clarke intenta reconciliar las dos partes del conflicto:

Quality, number and the sweet divisions

Of reason may forget their schoolmen now

And door-chill, body's heat, anger of vein,

Bring madness in our sleep. I have endured

The enmity of my own mind that feared

No argument; but $\mathrm{O}$ when truth itself

Can hold a despairing tongue, what recompense

To find my name in any mortal mouth?

Este poema vuelve la mirada de nuevo hacia los escolásticos medievales $\mathrm{y}$, por supuesto, hacia Aristóteles, con el que mantienen conexiones necesarias que ayudan a comprender las líneas de Clarke. Durante toda la Edad Media surgieron diversas teorías sobre la fe y la razón, la religión y la filosofía. Una de ellas era la "Teoría de las dos verdades", que defendía la existencia de una verdad religiosa y otra filosófica, pudiendo aparecer no sólo como diferentes, sino como contradictorias, y ser ambas admitidas a un mismo tiempo. Esta teoría la rechazaba la Iglesia porque no admitía que, procediendo de Dios tanto el contenido de la fe como la razón pudieran oponerse entre sí. Para Juan Escoto Eriúgena el ejercicio de la razón debía preceder a la fe; San Anselmo de Canterbury, cuya filosofía se resume en Credo ut intelligam (creo para comprender), opina lo contrario, que el conocimiento y aceptación de la fe deben preceder al ejercicio de la razón.

\footnotetext{
"Una versión algo diferente de este poema había aparecido con anterioridad en CP (1936).
} 
Estos filósofos, sin embargo, no conocían las dọctrinas de Aristóteles porque eran prácticamente desconocidas en el Occidente cristiano. A partir del siglo XII, los árabes las fueron introduciendo en Europa a través de España ${ }^{12}, \mathrm{y}$ aunque estas doctrinas llegaron contaminadas de las teorías de los intermediarios, su influencia en las universidades y en los medios cultos de la época fue tal que la Iglesia, temiendo por la fe, se apresuró a tomar medidas preventivas ${ }^{13}$. $\mathrm{Y}$ no era para menos, porque Aristóteles se desviaba del credo cristiano hasta el punto de negar la inmortalidad del alma. Sin embargo, estas medidas fueron vanas porque la filosofía aristotélica formaba parte ya de la historia.

A pesar de todo, Santo Tomás de Aquino demostraría que parte de la filosofía de Aristóteles era perfectamente compatible con el Cristianismo, y que:

El aristotelismo, debidamente adaptado y prolongado, podría constituir un profundo y coherente cuerpo de doctrina filosóficoteológica que acabase con la vieja pugna entre el hombre de la fe y el amante de la antigua cultura, entre el naturalismo de la razón y lo sobrenatural de la gracia, lucha que muchas veces se operaba en la propia mente de cada hombre. (Gambra 126).

Santo Tomás llegaría a una solución media en las posturas enfrentadas, en la que la filosofía dejaría de ser una mera servidora de la teología. Además, establecería un límite en el que se encontrarían las verdades reveladas de la fe, pero accesibles

\footnotetext{
${ }^{12}$ Fue esencial la labor de las escuelas de traductores, que recibirían la protección del rey de Castilla Alfonso X el Sabio. La más famosa fue la Escuela de Traductores de Toledo.

${ }^{13}$ El Concilio provincial de París de 1210 prohibió la lectura de los textos aristotélicos, y el Papa Gregorio IX reiteró años después la prohibición ( $c f$. Gambra 124).
} 
también a la razón. En resumen, podemos conocer la existencia de Dios a través de la razón, y como aquella es necesaria para nuestra salvación, Dios ha revelado también unas verdades iniciales o básicas para aquellos que no puedan acceder a la existencia de Dios a través de la razón. Es decir, "hay unas verdades-límite que para unos son de razón y para otros de fe, y constituyen lo que Santo Tomás llamó prambula fidei (preámbulos a la fe)" (Gambra, 128). Con esta teoría, Santo Tomás formula la solución media sobre la cuestión de nuestro conocimiento de Dios.

Pero volvamos al poema. Clarke se identifica con esos "schoolmen", a los que recomienda que se olviden de reconciliar a Aristóteles con la Iglesia porque el intento de armonizar ambas doctrinas había fracasado anteriormente. Aristóteles y la Iglesia vienen simbolizados de forma metonímica: el primero mediante sus categorías $^{14}$, que Clarke denomina "sweet divisions"; la segunda a través de los efectos de los rigores de la fe - “door-chill, body's heat, anger of vein" (3) - y que perturban el sueño del poeta. Estas imágenes nos recuerdan inmediatamente al eremita de "Celibacy", que no podía reconciliar su fe con el deseo. Clarke, de igual manera, ha intentado buscar el equilibrio pero no ha podido. Su búsqueda de la verdad no lo ha liberado de su temor al juicio de Dios, por lo que la fama que pueda adquirir a través de su poesía no le va a compensar por la pérdida del cielo.

Hay, sin embargo, otras posibles lecturas de "No Recompense" que se apartan ligeramente del concepto estrictamente religioso. El poema podría ser la

\footnotetext{
${ }^{14}$ Aristóteles hizo una división del ser en grandes grupos. A esta división la llamó categorías, que son como grandes casilleros en los que entran todas las cosas (Gambra 68).
} 
respuesta del poeta a cualquiera que abusara de su nombre, como hizo Beckett, pero el poema había aparecido en una versión ligeramente distinta en 1925, fue publicado en Collected Poems en 1936, y Murphy, la novela de Beckett salió a la luz en 1938, con lo que Clarke no podría haberlo escrito en respuesta a ella, en la que se ridiculiza a Clarke llamándole "Austin Ticklepenny" ( $c f$. McCormack ${ }^{15}$, “Austin Clarke” 95). Para McCormack, el poema se centra en la idea de la infamia:

If the poet can acknowledge truth to himself and yet hold silent, what recompense is to be gained if his name is spoken by others for such utterance must confirm a truth of which he despairs or state an untruth. (McCormack, "Austin Clarke" 96)

Para Tapping ( $A C$ 165) el poema "challenges the idea of fame, stating with its title and mournful conclusion that the world is nothing when a man's soul is at stake". Nosotros creemos, sin embargo, que independientemente de estas y otras posibles interpretaciones (puede haber tantas como lectores), la intención de Clarke era la de exponer una vez más el conflicto que bullía en su interior y con el que tenía que bregar para, al menos, encontrar un equilibrio.

Como hemos visto, "No Recompense" retoma la dicotomía del espíritu y la carne, que era el leit motif de Pilgrimage and Other Poems. En realidad, es uno más de los dilemas que forman el gran tramado de oposiciones que domina la obra

\footnotetext{
${ }^{15}$ Mc Cormack encuentra ecos de este poema en el poema "Lycidas" de Milton - "Fame is no plant that grows on mortal soil"- o en la poesía de Shelley - "Such is the tyrant's recompense: 'tis just; / He who is evil can receive no good" ("Austin Clarke: The Poet as Scapegoat of the Modernism" 95).
} 
de Clarke, y que es la clave de nuestro estudio. "Repentance"16 (186-187), poema confesional, se centra también en problemas de conciencia, cuyo origen reside en el pecado sexual. Pero el poema, sin embargo, no reclama independencia sino sumisión:

[It] looks back wistfully to the time when he found release and escape from his problem in the west of Ireland $[\ldots]$ and states that when intellectual doubt brings spiritual despair one has only prayer left" (Harmon, "Later" 47).

En este poema, Clarke recuerda su estancia en el Oeste de Irlanda, donde visitó muchos de los lugares asociados con la mitología y el folclore que había descubierto en la poesía de los poetas del Resurgimiento Literario Irlandés. Como ya vimos en el capítulo anterior, Clarke se sentía profundamente atraído por la cultura, el arte y la religión de la época medieval, donde la razón convivía en armonía con la fe:

When I was younger than the soul

That wakes me now at night, I saw

The mortal mind in such a glory -

All knowledge was in Connaugt. (1-4)

\footnotetext{
${ }^{16}$ Este es un poema confesional, y así lo expresa Clarke en sus notas: "The Confession poem was a recognised literary form in Gaelic and lasted till the eighteenth century" $(C P, 548)$. Según Halpern (67), este poema se asemeja a otros poemas confesionales de poetas modernos, como los de Robert Lowell y Sylvia Plath. Asimismo, muchos críticos han evitado hacer análisis de este poema por su dificultad. Halpern cita a a Robert Farren, quien se quejaba de la oscuridad del poema: "In it he speaks so arcanely, lurks and skulks in such pitchy corners of language, that what he says is often matter for debate ... [and] ... still though one can, with certain confidence, conjecture its general drift, and some of its detail, details remain which obscure entire understanding" (67).
} 
Pero en la estrofa hay un elemento disonante, algo que hace que el poeta no pueda conciliar el sueño y que su fe esté dominada por un miedo irracional al castigo eterno: "Judgement hour / That hides the sun in the waters" (8-9), imagen asociada asimismo con oscuridad. El origen de sus temores se encuentra en su prìmera experiencia religiosa, y que el poeta recuerda de forma epifánica en su visita a Croagh Patrick ${ }^{17}$ :

$$
\text { ... I felt }
$$

Repentance gushing from the rock;

For I had made a bad confession

Once, feared to name in ugly box

The growing pains of flesh. (15-18)

El poeta se ve acosado por el recuerdo de su fracaso al no poder confesar su lucha interior con la carne - "the growing pains of flesh". Esto es una declaración directa del conflicto entre la necesidad sexual y las enseñanzas de la Iglesia sobre la castidad ${ }^{18}$, y que constituyó uno de los elementos clave en la crisis nerviosa que sufrió Clarke en su juventud, relatada en Mnemosyne Lay in Dust.

Al igual que en "Night and Morning", el poeta, ahora un penitente, se encuentra en misa; el sacerdote está a punto de darle la espalda - "the celebrant / Has turned to wash his mouth in wine" (20-21) - y, cuando la mente se encuentra en estado de desesperación, cuando la fe y la edad han reemplazado a la naturaleza y a la juventud - "The soul is confined to a holy vessel, / And intellect less than

\footnotetext{
${ }^{17}$ Véase nota $\mathrm{n}^{\circ} 6$ del capítulo II.

${ }^{18}$ Este conflicto es también el tema central del poema "Celibacy", comentado en el capítulo II.
} 
desire" (22-23) —, cuando la razón no encuentra otra salida, solo entonces, afirma el penitente, queda la oración:

O I will stay to the last Gospel,

Cupping my heart with prayer:

Knuckle and knee are all we know

When the mind is half despairing. (24-27)

Las cuatro primeras líneas de la última estrofa empiezan con una nueva referencia a las tierras de Connaught donde, según Clarke, los habitantes tienen una religión y un fervor propios, y donde parece haber una perfecta combinación entre paganismo y Cristianismo, porque la religión no tiene por qué estar reñida con el folclore:

No story handed down in Connaught

Can cheat a man, nor any learning

Keep the fire in, turn his folly

From thinking of that book in Heaven. (28-31)

La preferencia de Clarke por este modo de vida contrasta con el que le han inculcado a él. En las últimas cinco líneas de la estrofa, el léxico revela el conflicto entre tener fe o carecer de ella: "caught", "dragged", "torment", "dreadful", son palabras que ponen de manifiesto el terror a la condena eterna. Las mismas líneas, sin embargo, parecen destilar una fina ironía al preguntarse el poeta si podría salvarse en el último momento si se arrepintiera:

Could I unbutton mad thought, quick-save

My skin, if I were caught at last

Without my soul and dragged to torment, 
Ear-drumming in that dreadful place

Where the sun hides in the waters? $(32-36)$

Para Schirmer, el arrepentimiento que el poeta sintió en Croagh Patrick “degenerates into hypocritical speculations about deathbed repentance" (PAC 49.).

Aunque en el poema anterior parece haber cierta confianza en obtener la salvación eterna arrepintiéndose en el último instante, las tensiones que origina la oposición entre fe y razón son difíciles de erradicar, como se ve en "Mortal Pride" (182), en el que Clarke admite que hay un vacío insalvable entre ambos polos. En realidad, el problema de Clarke está en su negativa a someter de forma consciente su voluntad a una voluntad divina. El poeta cree en la autosuficiencia e individualidad del espíritu, y se siente orgulloso de ello, pero lo que le ocurre es que está obsesionado con la idea de rechazar una religión de la que no puede deshacerse. Hay un extraordinario parecido entre el protagonista de A Portrait of the Artist as a Young Man, Stephen, y Clarke. El primero está completamente seguro de sus acciones, aunque sean un error - "I am not afraid to make a mistake, even a great mistake, a lifelong mistake, and perhaps as long as eternity too" (251) - , pero Clarke no parece tener tal arrojo:

When thought of all our thought has crossed

The mind in pain, God only knows

What we must suffer to be lost,

What soul is called our own

Before the truth was hid in torment

With nothing but this mortal pride 
I dreamed of every joy on earth

And shamed the angel at my side. (1-8)

Tapping menciona una idea importante que se deriva de estas líneas: "If 'God only knows', then it is impossible for churchmen to know the truth about the. redemption and salvation" ( $A C$ 165). Lo cual equivale, por un lado, a negar la autoridad de la Iglesia, pero por el otro, a seguir encadenado a la fe que esa Iglesia le inculcó. En la segunda parte de la estrofa, Clarke recuerda su inocencia, cuando no era consciente de los problemas de conciencia que le produciría la religión, cuando su orgullo - sea éste intelectual, espiritual, o carnal, en cualquier caso mortal - no se encontraba amenazado por los dogmas de la Iglesia. El orgullo fue el pecado que sumió al hombre en las tinieblas del pecado original — su deseo de ser como Dios. El pecado original derrotó al hombre antes de que éste conociera su existencia, y como dice Halpern,

Clarke is resentful because he feels that it has not only deprived us of joy in procreation, of enjoyment of the physical world but also, by its implication of man's limitations, it has robbed us of ultimate creativity of man's intellect. ( $A C$ 65)

Las líneas de la estrofa parecen negar la posibilidad de inocencia, porque el pecado puede ser tanto de obra como de acción. Esta idea la desarrolla en la segunda estrofa, en la que degrada el sacramento del matrimonio:

Pray, how shall any bride discover

A husband in the state of bliss,

Learn in the curious arms of love

The ancient catechism 
Man must obey? She never fears

He will forget the sacrament.

But thought is older than the years:

Before our doom, it came and went. (9-16)

Es decir, es imposible que una mujer encuentre un marido en gracia, porque lo más probable es que éste olvide el sacramento del matrimonio y disfrute de su propia sensualidad. La actividad intelectual del hombre era libre antes de que cayera en el pecado original. El hombre, por tanto, no es libre porque ha perdido su independencia intelectual, y está constantemente amenazado por esa oscuridad religiosa que inunda su alma. El mensaje del poeta es que una fe que no puede abrazar la razón es una fe que hay que rechazar. El dogma anula la vitalidad inquisitiva de la razón, por lo que llegar al equilibrio anhelado se hace cada vez más difícil. En palabras de Tapping, "Faith and knowledge are now irreconcilable; the latter denies God, the former limits his creation, mankind" ( $A C$ 168).

Estas ideas, ya expuestas en "Night and Morning", vuelven a aparecer en el último poema del volumen, "The Jewels" (191-192), y en él Clarke sopesa los pros y los contras de ambos lados del conflicto:

The crumbling centuries are thrust

In hands that are too frail for them

And we, who squabble with our dust

Have learned in anguish to dissemble.

Yet taken in the darkest need

Of mind, no faith makes me ashamed. 
Whether the breath is foul or sweet

The truth is still the same. (1-8)

En esta primera estrofa hay una clara intención de someterse a la verdadera realidad del hombre, su mortalidad, verdad que admite Clarke no sin temor: "we. have learned in anguish to dissemble". Desde que apenas tiene uso de razón - "hands that are too frail" - el hombre es una víctima de todos esos siglos de debate entre razón y fe, del drama de la conciencia de la estirpe católica en Irlanda (cf. Harmon, AC 84; Mercier, "Poetry" 97). En sus memorias, Clarke describe concisamente la verdad de la que habla el poema: "We are bred among stories that are older than ourselves and we disappear from sight, with the last aid of a little Latin, in the fond hope that all cannot be rot" (TRBC 62).

Pero a pesar de la aceptación de su destino, Clarke se pregunta por qué ha de temer si es la razón la que se impone a la religión - "If ordinary thought prevail / In all this knocking of the ribs"-, y por qué ha de dudar por la mañana al despertarse y sentir el terror que el conflicto entre la razón y la fe, es decir entre "the jewels and carbons of the consciousness", le mortifica durante el sueño:

Why should I hesitate at morning

Or wake a memory of myself,

All eyes, terrible as the jewels

And carbons of the consciousness

That waste the night in falsehood? (12-16)

El poeta está dispuesto a abandonar su sufrimiento, porque continuarlo es admitir que una Iglesia en la que ya no cree tiene razón. Hubo un tiempo en el que 
él podía participar de la comunión de los creyentes y fieles. Esto le obligaba a vivir en un laberinto en el que la duda y la desesperación eran el pan de cada día. Ahora, sin embargo, debido a su independencia intelectual, está excluido:

The misery of common faith

Was ours before the age of reason.

Hurrying years cannot mistake

The smile for the decaying teeth,

The last confusion of our senses. (25-29)

Con su racionalismo, "the wonder, the ingenuous childhood belief and delight in the mysteries of religion are gone" (Tapping, $A C$ 169). En las tres últimas líneas del poema, Clarke lamenta la inocencia perdida antes de entrar en la edad de la razón:

But $\mathrm{O}$ to think, when I was younger

And could not tell the difference,

God lay upon this tongue. (30-32)

En los seis poemas analizados hasta ahora hemos escuchado directamente la voz del poeta, que analiza su propio conflicto interno bajo la sombra de la temida oscuridad. En los cinco poemas restantes, Clarke nos habla a través de una máscara, que le ayuda a enfrentarse con el mismo conflicto pero desde una posición más distante.

The Lucky Coin" (187-188) es un poema en el que Clarke contrasta la Iglesia de la Irlanda de las Leyes Penales con la que surgió después de la 
Emancipación Católica ${ }^{19}$, que puso fin a éstas, y se fue volviendo cada vez más poderosa, llegando al cenit de su poder en la época de Clarke. La moneda del título se refiere a la que se encuentra fuera del seno del dogma eclesiástico, es decir, a la que impulsa a la gente a disfrutar de la vida; en palabras de Garrat, "this coin of life is the freedom to love, to dance, to sing, which the clergy has taken away" ("Mortal" 104). Clarke celebra en este poema los días en los que los católicos disfrutaban de más libertad: "A coin of different shape / That never came from Salamảnca"20 (6-7). Ahora, en los tiempos después de la Insurrección de 1916, Irlanda vive bajo una desmesuradamente poderosa Iglesia que desaprueba los placeres sensuales del ser humano a la vez que desconfía de cualquier manifestación que provenga del uso natural del intelecto humano, es decir, de la razón:

Not one of us will ever find

That coin of different shape

For it was lost before our rising

Or stolen - as some say.

But when our dread of the unseen

Has rifled hole and corner,

\footnotetext{
${ }^{19}$ La Emancipación católica consistió principalmente en la "Equiparación de los derechos de los católicos a los de los protestantes en la vida pública, diversos preceptos legales y la carrera militar. Tal medida, que se hizo efectiva en abril de 1829, pretendía poner fin a una larga lucha por los derechos de los católicos y un largo periodo de marginación y duras privaciones" (Hurtley. et al. 47).

${ }^{20}$ Durante los años de las Leyes Penales del siglo XVIII, la educación de sacerdotes católicos estaba prohibida, por lo que los estudiantes solían irse a estudiar a Europa: "Salamanca was the most outstanding of the Iberian colleges. Nurse of bishops, provincials, theologians, martyrs, and in great number, missionaries, it sent home in the space of a hundred years some five hundred priests to Ireland, England, and Scotland" (Citado en Harmon, AC 87).
} 
How shall we praise the men that freed us

From everything but thought. (33-40)

Las dos últimas líneas del poema son clave a la hora de entender los conflictos que afectan al pueblo irlandés. Daniel O'connell y "otros hombres", quizás les que participaron en la Insurrección de Pascua de 1916 o los que murieron durante la guerra contra Inglaterra, contribuyeron a liberar Irlanda del yugo británico, pero no quedaron totalmente liberados: "they were freed form external control, but significantly they were still ... prisoners of their own minds" (Halpern 68). El poema muestra el origen del conflicto que aparece en todos los poemas de Night and Morning: la libertad del hombre enfrentada a las restricciones de conciencia que imponen los dogmas de la Iglesia Católica.

La Irlanda que surgió después de la Guerra Civil de 1922, trajo aparejada una serie de restricciones de la libertad espiritual y artística en Irlanda. El nombre de Free State - la condición de República Irlandesa no se consiguió hasta 1948 era la denominación irónica de un estado que seguía manteniendo impedimentos considerables: dependía de la Corona británica y formaba parte de la Commonwealth, entre otras. Como ya apuntamos en el capítulo anterior, Irlanda anhelaba deshacerse del yugo británico, pero no tenia una ideología clara, ni tampoco un deseo inmediato de cambiar el sistema social y económico. Así, esta nueva Irlanda asumió básicamente la misma estructura legal que hasta entonces había regulado la vida socio-política irlandesa. Pero además de todo esto, tanto Gran Bretaña como Irlanda se esforzaron en controlar estrictamente lo que se 
llamaba "literatura obscena", control que sería aún más estricto bajo los auspicios de la Iglesia Católica. Pronto se promulgaron leyes que controlaban la moralidad irlandesa. Una de las más tristemente célebres fue la Ley de Censura de Publicaciones de 1929, que Clarke satiriza en "Penal Law" (189):

\section{Burn Ovid ${ }^{21}$ with the rest. Lovers will find}

A hedge-school for themselves and learn by heart

All that clergy banish from the mind,

When hands are joined and head bows in the dark.

De nuevo aparece el conflicto de sexualidad contra castidad, el instinto natural del hombre frente a la castidad impuesta por la Iglesia, sólo que esta vez actúa en connivencia con el Estado. El título hace referencia a las Leyes Penales que se promulgaron contra los católicos en el siglo XVIII, pero el objetivo es la mencionada ley de censura. Al final, el efecto es el mismo: suprimir, reprimir, coartar la libertad del hombre. En el primer caso, la leyes limitaban las acciones de los católicos; en el segundo, la Iglesia Católica, cuya historia está llena de censura y persecución, es la que ahora no duda en censurar el instinto natural del individuo.

"Penal Law" muestra la futilidad de las leyes eclesiásticas al prohibir el deseo humano. De igual manera que durante las Leyes Penales los católicos idearon un modo de burlar la autoridad - las llamadas "hedge-schools"22 -, de

\footnotetext{
${ }^{21}$ La referencia a Ovidio sirve de correlato histórico. Ovidio fue censurado en la Roma Imperial por haber escrito un poemario sobre el amor: Ars Amatoria.

${ }^{22}$ Las Leyes Penales prohibían la enseñanza en escuelas católicas. Las "hedge-schools" surgieron para eludir estas medidas y enseñar de forma clandestina. Éstas "sometimes consisted of little more than the shelter of a hedge or barn. The name continued in use when a hut or the home of a pupil was a more usual location.... Official figures suggest that in the 1820 s between 300,000 and 400,000 children attended, the number of schools rising to 9,000 by 1824" (The Oxford Companion to Irish History 238).
} 
igual forma, el hombre y la mujer aprenderán las leyes del amor dè forma natural - “by heart” - y esquivarán el grillete dogmático de la Iglesia. La última línea del poema alude tanto al sacerdote en confesión, y de quien los amantes harán caso omiso y seguirán sus propios instintos, como a los propios amantes, que optan por una religión propia, basada en el amor y no en la censura. Pero a pesar de la rebeldía innata del hombre caracterizada por oponerse a cualquier tipo de opresión o censura, Clarke sabe que no es sencillo deshacerse del sentido de pecado y de culpabilidad que los dogmas católicos han inculcado en la conciencia del individuo, como bien muestran las líneas de "Her Voice Could Not Be Softer" (189):

Suddenly in the dark wood

She turned from my arms and cried

As if her soul were lost,

And $\mathrm{O}$ too late I knew,

Although the blame was mine,

Her voice could not be softer

When she told it in confession.

Ocurren dos acciones en el poema, y las dos tienen lugar en la oscuridad. La primera es el acto del amor, que ocurre en un oscuro bosque, donde la muchacha, al sentirse afligida por el complejo de culpabilidad que le causa su conciencia, se aparta de su amante porque "she cannot help seeing their lovemaking as the church would see it - that is, as a sin" (Schirmer, PAC 53). Pero el hombre tampoco escapa de sus complejos y se culpa a sí mismo al ver la reacción de su compañera. 
La segunda acción tiene lugar en un confesionario, donde la muchacha, avergonzada por seguir las leyes de su propia naturaleza, confiesa su pecado.

Otro poema en el que Clarke se oculta detrás de una máscara es "The Straying Student" ${ }^{\text {B }}$ (188-189), uno de los poemas de Clarke que más frecuentemente aparece en antologías. Es un poema central, y no solo porque aparezca en el centro del poemario sino porque,

It explores love, chastity, religion, clericalism, art, faith and intellectual reason, pitting one against another in the portrait of an eighteenth century Irish scholar from Inishmore who had gone to Salamanca to study for the priesthood, but had been sent home a failure. (Halpern 69)

El poema adopta la forma de un aisling y combina el conflicto entre cuerpo y espíritu de Pilgrimage and Other Poems y el de fe y razón de "Night and Morning". Nos encontramos nuevamente en misa, en una de las islas de Aran - Inishmore ${ }^{24}$ :

On a holy day when sails were blowing southward A bishop sang the Mass at Inishmore,

Men took one side, their wives were on the other

But I heard the woman coming from the shore:

And wild in despair my parents cried aloud

For they saw the vision draw me to the doorway. (1-6)

\footnotetext{
23 '..'Student' in Clarke's poetry generally connotes a young man studying for the priesthood, either in the distinctive Hiberno-Romanesque conditions of pre-Norman Ireland or during the years (c. 16901795 ) when Catholic education was proscribed under the Penal Laws" (Maxton 215).

24 "Innishmore" es la isla más grande de las Islas Aran.
} 
En esta primera estrofa, se pueden advertir varios puntos que no podemos pasar por alto. Las dos primeras líneas presentan una primera oposición: la obligación de asistir a misa en un día en que la Iglesia conmemora una fiesta religiosa importante, puesto que el sacerdote está celebrando una misa cantada, y la tentación a disfrutar del ocio y la diversión que ofrece la escena marina. Vemos la segregación de sexos, los hombres y las mujeres se sientan separados, lo que pone de manifiesto el poder divisorio que ejerce la Iglesia. A mitad de estrofa, una conjunción adversativa, "But", introduce un cambio en la secuencia narrativa. Por la playa se oye acercarse a una mujer ${ }^{25}$, que introduce la segunda oposición de la estrofa. Por un lado tenemos a los padres del narrador que gritan desesperados y que representan las convenciones sociales y religiosas; por otro, la atracción seductora de una misteriosa mujer que arrastra a su hijo y que representa lo opuesto a lo socialmente establecido. ¿Quién es esta visión en forma de mujer que se le aparece al estudiante y provoca el temor de sus padres? ${ }^{26}$ :

Long had she lived in Rome when Popes were bad,

The wealth of every age she makes her own,

Yet smiled on me in eager admiration,

And for a summer taught me all I know,

Banishing shame with her great laugh that rang

As if a pillar caught it back alone. (7-12)

\footnotetext{
${ }^{5} \mathrm{La}$ asociación no es solamente con los aislings de los siglos XVII y XVII, sino también con los cuentos mitológicos en los que una mujer llegaba del mar y arrastraba a los hombres al Mundo Invisible (Harmon, $A C$ 86).

${ }^{26}$ Mercier apunta que se puede asociar a esta mujer con Luxuria, la lujuria personificada, o con Scientia or Sophia, personificaciones de la ciencia y del saber ("Mortal" 95).
} 
Para empezar, vemos que la mujer está asociada con la corrupción papal ${ }^{27}$ del siglo $X V$, y con el poder de la riqueza. Pero sus atributos también la relacionan con el resurgimiento intelectual del Renacimiento y con la liberación sexual. Es la misma mujer que encontrábamos en el poemario anterior, Pilgrimage and Other Poems, Gormlai y la joven de Beare (a la vez la oscura y la brillante tentación), símbolo de la mujer liberada sexualmente, y que representa todo aquello en lo que cree Clarke y que la Iglesia Católica se empeña en rechazar tan obstinadamente. El joven estudiante aprende de ella todo lo que sabe, y lo libera de los sentimientos de culpa y vergüenza - "Banishing shame"- que los dogmas de la Iglesia provocan en el individuo. No sólo la mujer instruye al joven estudiante en los placeres de la vida, sino que también lo forma intelectualmente, el otro extremo que la Iglesia siempre intentó combatir:

I learned the prouder counsel of her throat, My mind was growing bold as light in Greece; And when in sleep her stirring limbs were shown, I blessed the noonday rock that knew no tree: And for an hour the mountain was her throne Although her eyes were bright with mockery. (13-18)

Como vemos, la mujer amplía sus conocimientos intelectuales y artísticos, que se encuentran en los dos significados de "throat". Por una parte representa el orgullo intelectual - sinécdoque del habla-, y por otra simboliza el arte y lo sensual. Son, además, las palabras que provienen de la garganta de la mujer las que instruyen al

\footnotetext{
27 Esta corrupción se asocia con las disposiciones papales, y con la facilidad de obtener dispensas papales para la ordenación de los hijos de los sacerdotes durante el siglo XV (cf. Corish 55).
} 
estudiante en la filosofía: "as light in Greece". De nuevo, la luz estâ asociada con la razón y, en este caso, con la filosofía griega, que alababa tanto el cuerpo como la mente. A parte de "throat", como imagen sensual, tenemos también "her stirring limbs", imagen que se le aparece al estudiante en sueños y que contribuye a dar una imagen más precisa de quién es esta aparición. El estudiante observa a la mujer ante una montaña baldía - "noonday rock that knew no tree" - y que representa el trono de la mujer. Sin embargo, su mirada - "bright with mockery" - añade una nota de desconfianza, y recuerda a la tentación sexual que representaba la joven de Beare al desafiar abiertamente a la Iglesia: "Although the clergy pray / I triumph in a dream" (22-23).

La siguiente estrofa se caracteriza por la falta de precisión de las andanzas del estudiante:

They say I was sent back from Salamanca ${ }^{28}$

And failed in logic, but I wrote her praise

Nine times upon a college wall in France.

She laid her hand at darkfall on my page

That I might read the heavens in a glance

And I knew every star the Moors have named. (19-24)

"They say" y "college wall in France", cuya función es la de eliminar de forma sutil "the whole world of ecclesiastical discipline ... from his consciousness" (Martin, "Rediscovery" 419). Este mundo de lógica y disciplina religiosa queda rechazado a favor de la razón que ignora las restricciones religiosas — "she laid her 
hand at darkfall on my page". Sin estas rémoras, el estudiante ensancha sus conocimientos de forma que los cielos dejan de ser el remoto cielo de su religión y, además, aprende a ver desde un punto de vista no cristiano $\mathrm{y}$, por tanto, completamente diferente - "I knew every star the Moors have named".

El estudiante pasa solamente un verano con la mujer y la reverencia en su sueños durante una hora, lo que indica que su encuentro es meramente temporal. Abandona su carrera religiosa por ella, pero a su pesar no consigue eliminar de su conciencia el mundo de las prohibiciones religiosas. El conflicto entre razón y fe que alegremente parecía haber resuelto se manifiesta de nuevo en su interior. Y en el anticlímax que representa la estrofa final, nuestro estudiante revela la amarga sensación de que todo puede haber sido una ilusión:

Awake or in my sleep, I have no peace now,

Before the ball is struck, my breath has gone,

And yet I tremble lest she may deceive me

And leave me in this land, where every woman's son

Must carry his own coffin and believe,

In dread, all that the clergy teach the young. (25-30)

El resultado de la experiencia del estudiante es que ni en sueños ni en vigilia encuentra la ansiada paz espiritual, como tampoco la encontraba Clarke en "Night and Morning". La razón parece ser sencilla, "the great force of the church in Ireland is still to be reckoned with" (Schirmer, PAC 60; $c f$. Halpern 69). Además, hay que añadir que su propia mortalidad, ese ataúd que ha de llevar consigo, le

\footnotetext{
${ }^{28}$ La referencia a Salamanca identifica al estudiante como un seminarista irlandés que fue al Colegio de San Patricio en Salamanca ( $c f$. Harmon AC, 87).
} 
recuerda al estudiante que toda la libertad y el conocimiento que ha obtenido de la misteriosa mujer no garantizan que la vida continúe en el más allá, ni sirven para salvarle de las restricciones que impone la Iglesia.

El poema pone de manifiesto el esfuerzo del hombre del Renacimiento por liberarse del despotismo religioso mediante la razón y los sentidos. Clarke se ve a sí mismo como un hombre del siglo XV, y ansía verse liberado de las ataduras con que la Iglesia Católica de su época atenazaba la conciencia del individuo y restringía su desarrollo personal y artístico. El estudiante podría perfectamente ser una metonimia del propio Clarke, porque se enfrenta con lo mismo que Clarke lucha en todo este poemario: la incertidumbre, el miedo a la muerte y la desesperación espiritual; es decir, "the Darkness that man must dread at last".

Tanto en Pilgrimage and Other Poems como en Night and Morning, Clarke aborda el conflicto Iglesia / Individuo, ya sea desde la oposición cuerpo / espíritu o razón / fe, y en ambos casos hemos visto la imposibilidad de resolver el dilema. En ningun caso cuestiona Clarke la existencia de Dios, porque estos conflictos no tienen nada que ver con Dios sino con la idea que de Dios ha transmitido la Iglesia y con los dogmas que ésta ha impuesto sobre la conciencia individual y colectiva de todo un pueblo, en este caso el irlandés, y que es perfectamente transferible a cualquier otro pueblo en el que la religión católica haya estado o siga estando presente. Como muestran los poemas que hemos visto, la idea de Dios ofrecida por la Iglesia Católica es la que corresponde a la del Antiguo Testamento, un Dios vengativo, cruel, que arroja a sus pecadores a las llamas eternas del infierno. El 
cristianismo que aparece en los versos de Clarke corresponde a una religión en la que el temor a Dios y a su castigo son las principales virtudes. En ningún momento aparece Dios como un ser bondadoso cuya piedad ofrecería un atisbo de esperanza después de la muerte. Clarke, por tanto, se siente incapaz de reconciliar ambos polos del conflicto. Como veíamos en "Night and Morning", tampoco la Iglesia lo ha logrado. Clarke rechaza el contenido de la religión en la que ha sido educado y en la que no cree, pero como dice Mercier ("Mortal" 92), su actitud recuerda a la de Joyce, quien aun rechazando la fe católica siguió usando el simbolismo y los métodos intelectuales del Catolicismo durante toda su vida creativa. La mente de Clarke está saturada de la religión que le tortura, tanto en el sueño como en la vigilia.

No obstante lo anterior, Clarke no conseguiría decantarse por un polo u otro del conflicto señalado. Es, sin embargo, verdad que lograría en cierto modo encontrar un medio de arbitrar entre los dos y suavizar el sentido de culpabilidad y frustración que la religión le causara. 


\section{III.2. “Ancient Lights”: ¿La liberación espiritual de Clarke?}

Como indicamos en el capítulo I, después de Night and Morning (1938), Clarke no publicó poesía hasta 1955, en que reaparecía con un nuevo poemario, Ancient Lights. En éste, acometería un tipo de poesía completamente diferenté a lo que había escrito con anterioridad. Su estilo estaría libre de los tormentos de conciencia que impregnaban sus poemarios anteriores. Ahora recurriría a la sátira para exponer todo aquello con lo que no estaba de acuerdo, principalmente las acciones de la Iglesia Católica y el Estado en Irlanda. De nuevo, se centraría en los conflictos que surgirían de las relaciones y actitudes de estas dos poderosas instituciones con el individuo y hacia éste.

"Ancient Lights" (199-201), poema autobiográfico y homónimo del volumen de 1955 , sería el poema en el que Clarke mantendría a raya - aunque no liberaría completamente- los espectros con que la religión había poblado su conciencia. Varios críticos lo han visto como un poema central en el que se describe la resolución de las tensiones y conflictos expresados en los poemarios anteriores. Para Thomas Kinsella, "The struggles of conscience are over - sluiced away in "Ancient Lights"” ("Poetic" 134); para Martin, "In ... 'Ancient Lights' the accumulated load of guilt and suffering is stated and purged in eloquent catharsis" ("Rediscovery" 421); y, como último ejemplo, Frazier argumenta que:

"Ancient Lights" contains references to the initial point in history of Clarke's psychic conflict: guilt over masturbation; the medial point: impotence from guilt; and the terminal point: absolution from guilt as 
if they were all part of a day's anecdote, when actually this drama took fifty years to run its course. ("The Cod-Bewildered" 64)

No todos los críticos ven este poema como la solución a los conflictos de Clarke, puesto que él mismo se esfuerza en mantener que uno no puede resolver el. conflicto de forma satisfactoria. Schirmer afirma que,

'Ancient Lights' describes a moment of spiritual release with impressive force and conviction, but it is only a moment. That moment cannot release Clarke ... from either the struggle between his religious upbringing and his embracing of humanism". (PAC 60)

Nosotros, sin embargo, creemos que Clarke, a partir de este poemario, sí se encuentra más libre de las constricciones que mostraba en los poemarios anteriores, y su poesía ya no se muestra teñida de angustia y desesperación como lo había hecho hasta entonces. Por supuesto, cuando se nace en el seno de la religión católica y en un país tan consciente ${ }^{29}$ de ella como Irlanda, le será prácticamente imposible al individuo deshacerse del estigma - para bien o para mal - con que tiene que vivir.

"Ancient Lights" ${ }^{30}$ empieza con el contraste entre día y noche, entre luz y oscuridad, el mismo que conformaba los poemas de Night and Morning, y que lo convierte en una excelente transición tanto temporal como temática:

\footnotetext{
29 La religión en Irlanda ha sido una cuestión de identidad más que de fe. "Religious affiliation does not derive so much from conviction about the superiority of one theological doctrine over another, but it is rather a form of tribal identity which goes hand-in hand with political, social and economic alignments" (Rosa González 101).

${ }^{30}$ El título se refiere a un término legal, por el cual no se pueden levantar edificios y restringir el acceso de luz a ventanas ya existentes. Es decir, una casa tiene derecho legal a conservar sus "luces antiguas" (Maxton 234)
} 
When all of us wore smaller shoes

And knew the next world better than

The knots we broke, I used to hurry

On missions of my own to Capel

Street, Bolton Street and Granby Row

To see what man has made. But darkness

Was roomed with fears. Sleep, stripped by woes

I had been taught, beat door, leaped landing.

Lied down the bannisters of naught. (1-9)

Este mundo clarkeano de contrastes y conflictos comenzó en su infancia, cuando sabía más del mundo espiritual que del mundo real. La curiosidad típica de un niño le llevaba a recorrer la ciudad por el día y descubrir el mundo físico que lo rodeaba. Sin embargo, por la noche, le acosaban los miedos que le producía el mundo espiritual. La estrofa abunda en contrastes y correspondencias: el día está asociado con lo físico, con la curiosidad, con el coraje; la noche, en cambio, con lo espiritual y con el miedo. Su sueño, deslizándose por las barandillas de la nada, de la noche, del vacío, siempre hostigado por los temores que le habían inculcado- "woes / I had been taught" - refleja la condición de víctima del poeta.

Los temores que habitan sus sueños viene asociados con la religión en la siguiente estrofa: su renuente caminar hacia la iglesia, las imágenes tenebrosas que producen las velas, los altares y las vidrieras son el reflejo de los miedos que aterran al joven que se dirige a la confesión por primera vez:

Being sent to penance, come Saturday, I shuffled slower than my sins should. 
My fears were candle-spiked at side-shrines,

Rays lengthened them in stained-glass. Confided

To night again, my grief bowed down,

Heard hand on shutter-knob. Did I

Take pleasure, when alone - how much-

In a bad thought, immodest look

Or worse, unnecessary touch? (10-18)

De nuevo, la insistencia de las preguntas del sacerdote están centradas en el concepto de sexualidad que el catolicismo ha mantenido a lo largo de su historia: es malo mirar; es malo pensar; es malo tocar; es peor aun obtener placer de cualquiera de estas acciones. Clarke intenta en vano controlar su confesión:

...attempted

In vain to keep Dominican

As much i' the dark as I was, mixing

Whispered replies with his low words;

Then shuddered past the crucifix,

The feet so hammered, daubed-on blood-drip,

Black with lip-scrimmage of the damned. (21-27)

El crucifijo es el centro de atención, y en lugar de ser una imagen de esperanza, es una imagen de terror. Para Schirmer, "The crucifix is seen as especially grotesque, blackened with signs of man's corruption" (PAC 62). La atmósfera de terror y oscuridad que contiene esta estrofa es la misma que, como hemos visto, desprendían la mayoría de los poemas de Night and Morning.

El momento de liberación espiritual que se celebra en el poema comienza en la cuarta estrofa, donde el joven Clarke pasa de la claustrofóbica oscuridad de la 
iglesia y el confesonario a la liberadora luz del día. Afuera, los gorriones baten sus alas celebrando la vida natural, proscrita dentro de los límites del confesionario y de los muros de la iglesia:

Once as I crept from the church-steps,

Beside myself, the air opened

On purpose. Nature read in a flutter

An evening lesson above my head.

Atwirl beyond the leadings, corbels,

A cage-bird came among sparrows

(The moral inescapable)

Plucked, roof-mired, all in mad bits $\mathrm{O}$

The pizzicato of its wires! (28-36)

Goodness of air can be proverbial:

That day, by the kerb at Rutland Square,

A bronze bird fabled out of trees,

Mailing the spearheads of the railings,

Sparrow at nails, I hailed the skies

To save the tiny dropper, found

Appetite gone. A child of clay

Has blustered it away. Pity

Could raise some littleness from dust. (37-45)

Pero a partir de la sexta línea de la cuarta estrofa (verso 33), la oscuridad de la que ha emergido Clarke se asienta estilísticamente sobre sus versos. Clarke recurre a una parábola y no da demasiadas explicaciones sobre ella, lo cual confunde a sus lectores. Para varios críticos (cf. Kinsella, "Poetic" 135; Frazier, "CodBewildered" 63) la fábula del pájaro de estas estrofas es oscura y poco menos que 
inescrutable. El narrador se ve a sí mismo como un "cage-bird" al que se le ha desposeído de sus instintos naturales, debido probablemente a las enseñanzas de la Iglesia y su capacidad represora. Este pájaro ha escapado de la protección de su jaula y se encuentra a merced de los gorriones que no han conocido prisión algună y que, dejándose llevar por su naturaleza salvaje e indómita, empiezan a desplumar al pobre pájaro doméstico guiados por su instinto natural. Clarke, quizás recordando sus tiempos de violinista, plasma el ataque de los gorriones en clave de música ${ }^{31}$ : "O / The pizzicato of its wires!".

La dificultad de la quinta estrofa es la que ha causado más revuelo entre los críticos. Se han aventurado varias interpretaciones. La más literal de ellas es la que ofrece Harmon, para quien, según el manuscrito del poema, el pájaro dorado era un halcón asociado con un caballero armado. El léxico se adapta perfectamente a esta imagen -"Mailing", "spearheads", "railings", "nails"- y crea un ambiente de una extraordinaria fuerza metálica. La paráfrasis de la estrofa sería que el pájaro dorado apresa un gorrión con sus garras; Clarke lo ve y grita, de forma que asusta al ave rapaz que deja caer su presa - un metonímico 'appetite'. Así, un niño inocente - "child of clay ${ }^{32}-$ ha salvado la vida del gorrión. La lección vespertina que nos anunciaba Clarke en la estrofa no es la indefensión del pájaro ante el halcón, sino "the ability of an insignificant human being to rescue a sparrow from

\footnotetext{
${ }^{31}$ Frazier asocia esta fábula con la de Orfeo. Así, "The little fable is much like the myth of Orpheus. In that myth, Orpheus, as poet and as representative of the ordered life, is torn apart by the Maenads, women wild with passions of beasts. The dismemberment of Orpheus produces a final tragic song, just as the cruel beaks of the sparrows pluck music form the vocal chords of the cage-bird" (63).

${ }_{32}^{32}$ Según Harmon, en el manuscrito ponía 'poor child of Mary' (AC 158).
} 
the awesome bird" ( $A C$ 158). Kinsella, en cambio, se muestra absorto ante la oscuridad del pasaje: "it is not always possible to say what happens, even which bird is which in the second stanza" ("The Poetic Career" 135). Y Frazier, aventura una interpretación psicológica:

Psychological interpretation of Clarke's poetry must remain in many respects incomplete. It cannot provide the basis for an evaluation... [It] could probably cast some light ion Clarke's preference for certain puns, ambiguities, and fables, and perhaps it could explicate these. ("Cod-Bewildered" 64)

Esto hace que la estrofa adquiera otro cariz. Para Frazier, tanto los gorriones como el pájaro dorado están asociados con símbolos fálicos: "trees", "spearheads", "railings", "nails". El pájaro doméstico-"tiny dropper", "littleness"- está asociado con esos mismos símbolos pero en sentido opuesto a los anteriores, es decir, no en un estado de erección, sino de impotencia. Frazier también hace referencia a la pérdida de apetito y la relaciona con los mismos síntomas que tenía Maurice Devane ${ }^{33}$ cuando ingresó en el hospital psiquiátrico. La pérdida de apetito representa la represión del deseo natural que le impuso una conciencia obsesionada con los dogmas religiosos. "Pity", entonces, podría referirse a la piedad que no le mostró Margaret, su primera esposa.

Nosotros aceptamos las interpretaciones mencionadas, pero no podemos asegurar que el propio Clarke quisiera expresar el conflicto interior que le causó su matrimonio civil con Margaret en términos sexuales, o al menos como Frazier

\footnotetext{
${ }^{33}$ Maurice Devane es la máscara que utiliza Clarke en Mnemosyne Lay in Dust.
} 
quiere demostrar. Sabemos que el conflicto que le produjo su matrimonio, sumado a otras circunstancias que ya vimos en el capítulo II, provocaron en Clarke una crisis mental que lo mantuvo internado en un hospital psiquiátrico durante poco más de un año. La interpretación que ofrece Frazier nos parece rebuscada,principalmente porque en Mnemosyne Lay in Dust Clarke aborda este conflicto con más profundidad y no utiliza términos tan retorcidos. Ahora bien, como dice el propio Frazier "any interpretation that lends coherent meaning is worth serious consideration" ("Cod-Bewildered" 65), pero hay que tener en cuenta que la interpretación que hace Frazier es a posteriori, es decir, la formula conociendo de antemano el pasado personal del autor. Si no tuviéramos en cuenta su biografía, interpretar "trees", "spearheads", "railings", "nails" como símbolos fálicos erectos nos parecería forzar la exégesis del poema. Por supuesto, cualquier método es válido si es coherente y, en este caso, ambas interpretaciones lo son.

Pero esta liberación que parece experimentar el narrador al liberar al pobre pájaro indefenso de las garras de un pájaro mucho más poderoso (lo cual podría interpretarse como, por ejemplo, Clarke frente a la Iglesia), obliga a Clarke a preguntarse qué cambios puede introducir la Iglesia ahora:

What Sunday clothes can change us now

Or humble orders in black and white?

Stinking with centuries the act

Of thought. So think, man, as Augustine

Did, dread the ink-bespattered ex-monk, And keep your name. No, let me abandon 
Night's jakes. Self-persecuted of late

Among the hatreds of rent Europe,

Poetry burns at a different stake. (46-54)

Da la sensación de que se le pide al narrador que abandone el acto de pensar, puesto que el acto en sí apesta después de tantos siglos, y que siga a su tocayo San Agustín, representante de la obediencia y de la fe, en lugar de a Martin Lutero, que representa justamente lo opuesto, el intelecto libre. El narrador rechaza el consejo, por supuesto, y rechaza también la oscuridad y reclusión implícita en "night's jakes $^{34,}$. Al final, Clarke se reafirma en la poesía, porque ésta no arde en la estaca de la persecución o la herejía sino en el fuego de la imaginación, que solo persigue la libertad.

Después de haberse liberado de los miedos que le produjo la religión católica, sólo le queda al narrador la purificación mediante un bautismo figurativo. Así, Clarke recuerda el día en que se dirigía hacia casa y le sorprendió una tormenta de la que tuvo que refugiarse en una iglesia protestante, la conocida y temida Black Church ${ }^{35}$ :

I dared to shelter al locked door.

There, walled by heresy, my fears

Were solved. I had absolved myself:

Feast-day effulgence, as though I gained

\footnotetext{
"Entre los significados de "jake" está el de "privvy" o "outhouse", es decir excusado o baño. En el poema se refiere al estreñimiento que debió de padecer el exmonje Lutero (Maxton 235).

${ }^{35}$ Se refiere a la iglesia de St Mary, iglesia protestante construida entre 1829-39, pero conocida popularmente en Dublín como Black Church, debido a la naturaleza de la piedra que se oscurece rápidamente, especialmente cuando llueve. Hay una leyenda que dice que todo aquél que camine tres veces alrededor de ella se encontrará con el demonio. De aquí viene el título del primer volumen autobiográfico de Clarke, Twice Round the Black Church (cf. Maxton 234).
} 
For life a plenary indulgence. (59-63)

La última línea es significativa porque sugiere que Clarke puede ahora permitirse disfrutar de los placeres de la vida, tanto sensuales como espirituales.

La oscuridad y el terror descritos en "Tenebrae" y en la mayoría de los poemas de Night and Morning, se deslizan con el agua de la lluvia por los desagües de la iglesia. La última estrofa del poema, a pesar de sus intrincadas imágenes, celebra el nuevo estado del poeta, su liberación de las oscuras cadenas de la religión católica:

The sun came out, new smoke flew up,

The gutters of the Black Church rang

With services. Waste water mocked

The ballcocks: down-pipes sparrowing, And all around the spires of Dublin

Such swallowing in the air, such cowling

To keep high offices pure: I heard

From shore to shore, the iron gratings

Take half our heavens with a roar. (64-72)

La grandilocuencia de las líneas finales sugiere "something affecting the whole country ... but more particularly it refers to the 'shores' or conduits along the streets through whose 'gratings' the water roars in flood" (Harmon, AC 159). La Iglesia y sus oscuridades quedan por fin ahogadas en ese rugido final.

Pero a pesar de su liberación, Clarke es consciente de que la religión en la que fue educado sigue y seguirá impregnando su vida, crea o no crea en ella. Esto nos recuerda el comentario que le hacía Cranly a Stephen Dedalus en la novela de 
Joyce, A Portrait of the Artist as a Young Man, cuando le comenta cómo algo en lo que no se cree puede de hecho afectar la vida de las personas. Clarke verá desde ahora el problema religioso con más distancia, y pasará a partir de esta nueva etapa poética a comentar las versiones del drama de la conciencia del pueblo irlanđés en sus versiones socio-política y psíquica. 


\section{III.3. Martha Blake: La fe.}

Como dijimos en la Introducción, una de las razones por las que considerábamos a Austin Clarke como un autor importante es la de haber dotado a la mujer irlandesa de una voz hasta entonces ausente en el panorama literario irlandés. Ya hemos visto algunas mujeres en Pilgrimage, caracterizadas por su libertad sexual, más o menos paliada por las restricciones de conciencia provocadas por la religión. "Martha Blake" (184-185), en cambio, da voz a otro tipo de mujer: las que viven como víctimas de la opresión eclesiástica y política. Su función en Night and Morning es la de proporcionar otro punto de vista que equilibre las tensiones del poemario: la duda, el temor y la oscuridad que desprende la mayoría de los poemas contrasta con la satisfacción que obtiene la protagonista del poema de su fervor religioso. Para Tapping, la inclusión de este poema en este poemario es extraña: "Surrounded by the agonised complaints of Night and Morning, 'Martha Blake' is strikingly different" (203). Martha es una persona que vive al margen de toda tentación sexual y consagra su existencia a vivir exclusivamente según las normas de la Iglesia. Martha Blake $^{36}$ es la beata solterona homónima del poema, cuyo epitafio plasmaría excelentemente Clarke veinticinco años más tarde en "Martha Blake at 51", donde acometería de nuevo el

\footnotetext{
${ }^{36} \mathrm{El}$ personaje de Martha Blake está basado en Eileen, hermana de Clarke, y se pueden trazar varios paralelismos entre las dos: Eileen Clarke y su madre vivieron en 149 Rathgar Road entre 1939 y 1942. Eileen entró en la orden Carmelita, que tuvo que abandonar por problemas de salud. El deterioro físico y psíquico de Martha, en cambio, está asociado con su asociación con esta orden religiosa (Cf. Maxton, "Beyond the Pale" 14-15; Goodby, "The Prouder Counsel" 338).
} 
conflicto entre una doctrina religiosa y una fe más humanitaria en la libertad del hombre.

Antes de que el sol haya despuntado, Martha Blake se aventura por calles silenciosas en busca de refugio espiritual - "she dares / The silence of the street" (3-4). Camina sola, inmersa en sus pensamientos, hasta que las campanas de la iglesia rompen la quietud del alba y sus redobles rebotan en el patio de la iglesia. Martha Blake, en su solitaria carrera hacia la iglesia, abraza el sonido de las campanas en un atrevido y sensual abrazo: "O then her soul / Makes bold in the arms of sound" (7-8). La naturaleza erótica de esta imagen acentúa los sentimiento religiosos de la beata $\mathrm{y}$, al mismo tiempo, sugiere que "those emotions give the same kind of satisfaction that human love can provide" (Schirmer, PAC 54).

Este abrazo casi sexual de su alma con los sonidos metonímicos de las campanas delata sus ataduras con la religión católica, que no sólo la paralizan sino que también la ciegan sin dejarle ver más allá de lo estrictamente permitido:

But in the shadow of the nave

Her well-taught knees are humble,

She does not see through any saint

That stands in the sun

With veins of lead, with painful crown;

She waits that dreaded coming, When al the congregation bows And none may look up. (9-16)

Sus rodillas se han vuelto sumisas, y sus ojos no ven los santos de las cristaleras. Martha se encuentra arrodillada, presumiblemente con sus manos entrelazadas, sin 
atreverse a mirar hacia arriba porque cuando el sacerdote eleva la Sagrada Forma, la transubstanciación tiene lugar y el pan y el vino se convierten en el cuerpo y la sangre de Cristo. Este momento es el que preconiza el segundo advenimiento,

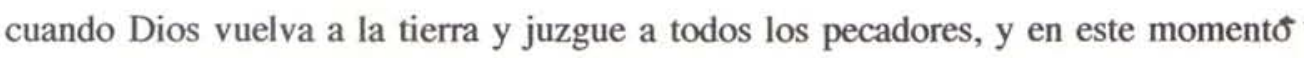
nadie debe mirar hacia arriba porque Dios está físicamente presente.

Después de la realización del milagro, Martha Blake, junto con otros fieles, se acerca al altar, se arrodilla piadosamente y espera:

She trembles for the Son of Man,

While the priest is murmuring

What she can scarcely tell, her heart

Is making such a stir;

But when he picks a particle

And she puts out her tongue,

That joy is glittering of candles

And benediction sung. (25-32)

En esta estrofa y en las dos siguientes, Clarke observa cómo Martha disfruta, cómo paladea el placer espiritual que le proporciona la comunión, e intenta comunicárselo al lector. Sin embargo, la lectura que algunos críticos hacen de estas líneas no es unánime (ya hemos dicho anteriormente que puede haber tantas interpretaciones como lectores). Para Harmon, el retrato que hace Clarke de Martha es "a gentle portrait of a pious woman whose life and devotion are uncomplicated" ("Later" 47), pero Halpern se opone y argumenta que "it is far from gentle; it is Clarke's first satire -its biting humour and criticism are unmistakable" (66). Donald Davie afirma que "In the poem as a whole there is 
nothing to offend the most devout Christian, and indeed it could have been written only by a poet who had experienced the Eucharist very fervently" ("Austin" 46); Schirmer (PAC 55) y Mercier ("Mortal" 97) opinan de igual manera. Nosotros unimos nuestra opinión a la de estos últimos y creemos que la intención de 'Clarke no era ridiculizar o burlarse de alguien que cree firmemente en la fe católica. Tengamos en cuenta que Clarke nunca desprestigia, ridiculiza o se burla de la religión en sí, ni de sus rituales. Él era católico e, independientemente de sus dudas y de que fuera practicante o no, no hemos advertido en sus poemas que Clarke rechace la religión como manifestación espiritual del ser humano. Otra cosa muy diferente es la forma en que esa religión ha sido y es inculcada en las costumbres de la gente a través de su portadora, la Iglesia Católica. El que la religión católica en Irlanda contribuyera a aumentar el grado de parálisis que afectaba a la sociedad irlandesa tiene más que ver con la jerarquía eclesiástica, que era la encargada de propagarla, que con la religión en sí. Clarke dirige sus invectivas contra la Iglesia Católica, no contra la religión, y el retrato de Martha es el retrato de una víctima de las circunstancias sociales de una época y del afán de ganar prosélitos de la Iglesia Católica.

El acto mismo de la comunión está relatado con un marcado tono sexual, que recuerda a la poesía de los poetas místicos españoles ${ }^{37}$ :

Her soul is lying in the Presence

Until her senses, one

\footnotetext{
${ }^{37}$ Véase nota 22 del Capítulo IV.
} 
By one, desiring to attend her,

Come as for a feast and run

So fast to share the sacrament,

Her mouth must mother them:

'Sweet tooth grow wise, lip, gum be gentle,

I touch a purple hem.' (33-40)

La boca de Martha advierte a los dientes, labios y encías de que han de ser amables porque van a besar la ropa morada del sacerdote. Después de recibir la comunión, o en términos místico sexuales después de unirse espiritualmente a Cristo, Martha siente una tranquilidad interna en la que su alma no tiene competencia con su cuerpo, desprovisto de toda autoridad:

But now she feels within her breast

Such calm that she is silent,

For soul can never be immodest

Where body may not listen. $(45-48)$

La última estrofa, que yuxtapone la "santidad" de Martha con la vida cotidiana de la ciudad, ofrece al lector dos perspectivas:

So to begin the common day

She needs a miracle,

Knowing the safety of angels

That see her home again,

Yet ignorant of all the rest,

The hidden grace that people

Hurrying to business

Look after in the street. (57-64) 
En la primera tenemos a Martha de vuelta a casa después de haber recibido su "droga" diaria: el milagro de la transubstanciación y su participación en él por medio de la comunión. Sabiéndose amparada por los ángeles que la acompañan sana y salva, Martha camina hacia casa sin prestar atención a la realidad cotidiana que bulle en la calle: esa "hidden grace" que no se encuentra en la oscuridad de la iglesia sino en la luminosidad de la vida cotidiana dublinesa. En la segunda, podemos interpretar esa "hidden grace" como la de la propia Martha, que es la que la gente de la calle nota en su júbilo y ansía para sí.

Sin embargo, veinticinco años más tarde, como veremos en el siguiente capítulo, esta Martha que ha dedicado toda su existencia a vivir de acuerdo con la fe católica, se verá literalmente abandonada y poco menos que rechazada por los representantes de esa fe en la que tanto cree. 
IV. SÁTIRA, IGLESIA Y ESTADO 


\section{IV.I. La sátira en Irlanda.}

"Sátira" es uno de los términos más imprecisos en las designaciones literarias. Etimológicamente, proviene de la palabra latina "satura", que significaba "olla podrida de manjares varios", "ensalada", "miscelánea", o, incluso, "batiburrillo", definiciones que se caracterizan por su imprecisión. En el siglo XVIII, Samuel Johnson definio "satire" en su diccionario como "a poem in which wickedness or folly is censured", y los grandes satíricos del mismo siglo como Swfit, Dryden o Pope no consiguieron definir este término de forma precisa. La sátira es un escrito en que se censura o ridiculiza a persona o cosas. Ha sido un género que admitía cierta variedad de formas, lo que justifica el origen latino del término. Históricamente la palabra proviene de la vieja Roma, y Quintiliano afirmó que la sátira era un fenómeno romano, aunque estaba familiarizado con las obras de Aristófanes y otras formas griegas que podrían etiquetarse como satíricas; sin embargo, los griegos no tenían ninguna palabra con que definir el carácter de sus obras. Los escritores romanos, al principio, utilizaron el vocablo "sátira" para referirse a una forma poética en concreto, pero también a otros escritos en prosa. Más tarde, el término se usó para denominar obras que eran "satíricas" en tono, aunque no en forma.

Los autores latinos Horacio y Juvenal establecieron las pautas que caracterizarían al género literario de la sátira, pero concibieron el papel de la sátira de forma diferente. Para el primero, la sátira se acerca imperceptiblemente a la comedia. El personaje de sus sátiras es el hombre común que ve los vicios y 
defectos humanos a su alrededor, los cuales le provocan risa en vez de ira. Juvenal, en cambio, adopta el papel del hombre recto que ve con horror la corrupción de su época y que se consume en ira y frustración, y su sátira se acerca a la tragedia, el melodrama y la pesadilla. Dryden se fijaría en estos dos estilos para dar su clasificación de la sátira: sátira cómica y sátira trágica, denominaciones que marcarían los límites de lo que se ha venido en llamar espectro satírico. La diferencia entre ambos tipos no es fácil, y habrá casos en los que el lector se encuentre ante situaciones fronterizas que dependerán de diferentes variables, "of which the most important is the previous knowledge and attitude of the reader" (Rosenheim 15). Pero lo que sí es un denominador común en todo el espectro satírico es la existencia de un ataque, "for in one way or another, satire seeks always to treat an object of some kind in an unfavorable way" (Rosenheim 12), y por tanto de un conflicto entre el satírico -o quienquiera que sea la voz narrativa - y un adversario o víctima, que a veces sólo será el medio para exponer un vicio o defecto.

Rosenheim ${ }^{1}$ comparte la división de Dryden, pero cambia la terminología y hace importantes precisiones. Sus dos extremos del espectro lo forman lo que él denomina sátira persuasiva y sátira punitiva. La primera equivaldría a la sátira de Juvenal, y la segunda, a la de Horacio. Desde el punto de vista del lector, el

\footnotetext{
' A la sátira se le pueden aplicar los tres géneros aristotélicos del discurso de la parte -el judicial, el deliberativo y el epidíctico- aunque en su aspecto negativo. Es decir, "the forensic exposure of past folly or evil, the epideictic incitement to blame rather than praise, and the deliberative exhortation to hostile action" (Roshenheim 12). Véase, Lausberg 22-23.
} 
objetivo de la primera es el de hacerle cambiar de opinión; el de la segunda, al contrario, es simplemente el de divertirlo. En ambos casos, la víctima aparece siempre bajo una perspectiva poco favorable, aunque en la sátira punitiva este punto de vista es aceptado a priori por el lector, a quien no se le pide que emita juicios de valor ni que actúe de una determinada manera; simplemente, que disfrute del oprobio, ridículo o castigo que recibe la víctima. Aunque esta línea divisoria entre ambos tipos de sátira no es exacta y, en cualquier caso, siempre dependerá de lo informado que esté el lector, el objetivo de la sátira en general es el de llegar a lo que llama Rosenheim "satiric truth", la verdad satírica que es lo que el satírico cree y lo que desea que crea el lector sobre los asuntos que trata su obra. Pero si las comedias invitan también a la audiencia a que se regodee en el castigo que recibe la víctima, ¿por qué no se las denomina sátiras también? La diferencia está en la particularidad del objeto del ataque. En la comedia, el personaje tipo podría haber sido cualquiera; en la sátira es alguien.

Hay, además, algo que ayuda a definir la sátira y, sobre todo, a diferenciarla de la retórica normal. Así, "all satire involves, to some extent, a departure from literal truth and, in place of literal truth, a reliance upon what may be called a satiric fiction" (Rosenheim 17), de forma que el lector sabe que lo que se dice no se puede tomar al pie de la letra y es consciente de lo que el autor quiere decir. Y aquí es donde cobra vital importancia el método - "satiric fiction" - que el autor emplea para transmitir su sátira. El satírico tiene a su disposición una inmensa variedad de dispositivos retóricos: fábulas, viajes imaginarios, anécdotas, 
personajes ficticios; y además puede emplear el sarcasmo, la ironía, la burla, la invectiva, la parodia, la exageración, el ingenio, etc., cualquier artificio que sirva para ridiculizar o degradar al objeto del ataque. No es de extrañar, por tanto, que a todo este batiburrillo literario lo llamaran los latinos "sátira". Sin embargo, ésta no tenía las mismas características en un país que en otro, ni en unas culturas que en otras. Vamos a ver a continuación cómo evolucionó la sátira en la Irlanda gaélica y en la Irlanda ocupada por Inglaterra.

En gaélico, el término "satira" tenía connotaciones diferentes a las de su versión latina o griega. El término del que se traduce "sátira" es "aer", "aor, aoir", que en su origen pareció tener un significado casi mágico. Más tarde vino a ser simplemente un ataque personal - "lampoon"- o una maldición contra alguien. Debido a su carácter mágico, el bardo gaélico gozaba de una posición privilegiada en la sociedad, llegando hasta tal punto su poder que incluso el clero le tenía cierto respeto. La sátira en gaélico puede estudiarse en dos periodos: el primero llega hasta finales de la primera mitad del siglo XVII, y se le conoce como periodo clásico o "bárdico", y el segundo finaliza con la Gran Hambruna de 1846-47 (Mercier, ICT 128).

Es difícil determinar la naturaleza de la sátira en gaélico debido, principalmente, a la ausencia de textos. En el Book of Ballymote, compilado hacia 1400, hay un pequeño tratado sobre los distintos tipos de sátira que había pero, según Mercier, no se puede saber si presenta una visión fiable sobre la práctica de la sátira en periodos más antiguos. Según este tratado, hay tres tipos de sátira: 
aisnés, o reproche; ail, insulto; y aircetal, sátira en verso. Esta última, a su vez, se dividía en varios tipos, tales como dallbach, indirecta; lánaír, sátira completa, y ainmedh, sarcasmo, entre otros ${ }^{2}$.

En los ejemplos que aparecen en la compilación mencionada así como en la compilación de Kuno Meyer $^{3}$, se vislumbra la actitud profesional del bardo gaélico: su exigencia de recibir pago o alojamiento por sus versos y su amenaza con satirizar si no se satisfacían sus demandas. Este último extremo aparece en el poema más largo que ha sobrevivido en el gaélico antiguo, Ammo Choimdhiu néll cid dogén fri firu Arddae? ${ }^{4}$ (O my God, what shall I do against the Fir Arddae?). El argumento se puede resumir en una única línea: "I shall satirize six times over". Básicamente, el poema es más una amenaza que una sátira, y en él, el poeta considera las forma de aniquilar a la tribu del condado de Clare a través de su burla.

Los numerosos ejemplos que aparecen en los tratados mencionados apuntan a que el tipo de sátira que se escribía estaba dirigida hacia individuos o grupos de individuos específicos, y la falta de hospitalidad y la tacañería eran las faltas más frecuentemente satirizadas. Progresivamente, se fue pasando de la sátira personal - también llamada "lampoon"- a una sátira más impersonal y generalizadora,

\footnotetext{
${ }^{2}$ Para un estudio más completo, que escapa al objetivo de esta tesis, ver los capítulos 5 y 6 de Vivian Mercier, The Irish Comic Tradition.

${ }^{3}$ La compilación referida es Bruchstïcke der älteren Lyrik Irlands, en la que aparecen ejemplos traducidos al alemán sacados de tratados de Irlandés Medio.

${ }^{4}$ Esta sátira está compuesta por Fingen mac Flainn contra Fir Arddae, un tribu de Country Clare. La obra data del siglo IX, ha sido editada por Kuno Meyer, pero no ha sido traducida a ningún idioma moderno.
} 
que aparece principalmente en las colecciones de, proverbios $\mathrm{y}$ aforismos conocidos como Trecheng Breth Féni (The Triads of Ireland) y Tecosca Cormaic (The Institutions of Cormac). A pesar de los esfuerzos por conseguir un tipo general de sátira,

It was the tradition of the lampoon that showed the greater staying power. Strings of alliterative epithets are almost as common in the satires written in the seventeenth and eighteenth centuries by David O'Bruadair, Egan O'Rahilly, and Owen Roe O'Sullivan, as they are in Kuno Meyer's little anthology of Early Irish satire. (Mercier, ICT 127).

Sin embargo, podríamos hacer una clasificación que comprendiera estos cinco apartados: personal, social, política, religiosa, y literaria. La sátira personal adopta normalmente la forma de ataque o invectiva dirigida a una persona o grupo concretos. Este tipo de sátira conservaba implícito su origen mágico y mantenía la creencia de que tenía el poder de infligir daño físico a su víctima. La sátira social tenía generalmente un solo objetivo: ridiculizar y denunciar a las clases inferiores. La sátira y la política nunca llegaron a combinarse de forma adecuada: los británicos ridiculizaban a los gaélicos por no hablar bien inglés, y los gaélicos se burlaban de aquéllos por no tener nombres gaélicos. Y en cuanto a la religión, Irlanda ha sido un país consciente de su religión, por lo que "we need hardly wonder at the bulk and vigour of the satirical literature which handles religious themes" (Mercier, ICT 171). La sátira religiosa consistía en ataques a los protestantes o a los apóstatas católicos, al clero católico, o a creencias religiosas 
específicas. La sátira profesional consistía en criticar el asunto, la técnica e incluso la relación del poeta con su público. Al ir adentrándose en el periodo moderno -1650-1850- los poetas gaélicos se juntaban en grupos en los que intentaban aprender de los demás y en los que se criticaban mutuamente.

Los siglos XVII y XVIII vieron la decadencia y casi extinción del gaélico, y no sería hasta el siglo $\mathrm{XX}$ cuando se empezó a plantearse el resurgimiento del gaélico como la recuperación no solo de un idioma y una tradición, sino de un identidad. Sin embargo, en Irlanda se hablaban el gaélico y el inglés, y la literatura creada en este idioma es la que realmente ha predominado en la cultura irlandesa y le ha dotado de la identidad literaria que posee en la actualidad. Mercier comenta que si la sátira es escasa en la literatura anglo-irlandesa reciente no se debe a la falta de popularidad de este género, sino más bien a las leyes inglesas contra el libelo. Estas leyes surgieron cuando el inglés se convirtió en el idioma de la mayoría de los irlandeses, lo cual obligó a que los ataques satíricos personales -lampoon - se propagaran oralmente o se imprimieran de forma privada. Joyce, por ejemplo, imprimió "The Holy Office" (1905) y "Gas from a Burner" (1912) en Trieste, y les envió copias a sus hermanos Stanislaus y Charles respectivamente para que las distribuyeran en Dublín ${ }^{5}$. Sin embargo, "there is little satisfaction in lampooning a fellow Irishman if one can never be sure that the victim will see the satire in print" (Mercier, ICT 183).

\footnotetext{
${ }^{3}$ Cf. Ellmann, James Joyce 200 y 337.
} 
Durante los siglos XVIII y XIX, la ley del, libelo no estaba todavía plenamente desarrollada, pero, por otro lado, el género satírico adolecía de la falta de una víctima digna. Los irlandeses nativos estaban atados de pies y manos por las Leyes Penales, y en el siglo XVIII, la literatura anglo-irlandesa estaba en manos de los protestantes de origen inglés. Si éstos querían escribir sátira, habría de ser en contra del gobierno británico en Irlanda, lo cual no les habría sido muy aconsejable. Solamente Swift se atrevió a satirizar a los de su propia clase, pero tenía el prestigio suficiente para hacerlo con relativa impunidad. Además, a los irlandeses, que empezaban a usar el inglés como lengua propia, les era moralmente imposible escribir sátira a la vista de las miserias que devastaban su propio país, especialmente la Gran Hambruna de 1847. Los novelistas católicos podían escribir sátira contra la Primacía Protestante - Protestant Ascendancy-, pero "[they] found themselves handicapped by their ignorance of the mores of their opponents (Mercier, ICT 186). La mejor sátira de la época se encuentra en la novela de Maria Edgeworth, Castle Rackrent, pero ella era de procedencia inglesa. En el siglo XX, los escritores del Resurgimiento Literario Irlandés que tenían dotes para la sátira - Joyce, O'Casey, Synge- "had too much compassion in their hearts to become pure satirists" (Mercier, ICT 186). La sátira anglo-irlandesa empezó con Swift, y aunque éste no tenía mucha consideración hacia el gaélico, Mercier argumenta que encaja perfectamente dentro de la tradición gaélica, y que se pueden trazar semejanzas entre el estilo de Swift y el gaélico. Una de ellas es la de actitud, un sentido arrogante del poder y del prestigio. Swift, como los bardos gaélicos, espera 
de sus víctimas que tiemblen ante él, porque está completamente seguro de que tiene razón. Un ejemplo moderno de este temor al satírico lo comenta Ellman en su biografía de Joyce: cuando se publicó Ulisses, los dublineses "asked each other in trepidation after the book appeared, 'Are you in it?' or 'Am I in it?' (364). La segunda es el desprecio por la moderación. La inmoderada furia de su sátira personal recuerda a la gaélica (recordemos que muchos de ellos fueron víctimas de sus sátiras, muriendo a manos de sus enemigos $\left.{ }^{6}\right)$, y Swift nunca se anduvo por las ramas a la hora de lanzar invectivas, como bien muestran A Modest Proposal y la cuarta parte de Gulliver. La última semejanza es la de la disposición de los poetas gaélicos a reprenderse entre sí -flyting-, y que practicaba Swift incluso con sus amigos, cuyos sentimientos más de una vez hirió profundamente.

Swift tuvo muchos imitadores, incluso autores gaélicos, pero su estilo era muy difícil de imitar. Maria Edgeworth en Castle Rackrent, Thomas Moore en Memoirs of Captain Rock, y John Mitchel en su Apology for the British Government in Ireland lograron acercarse a Swift con casi absoluta maestría. Para Mercier (ICT 201) Joyce fue el último gran imitador de Swift; en "The Holy Office" y "Gas from a Burner" “ $[\mathrm{He}]$ imitates Swift's octosyllabics with great skill, while its personal allusions, its scatology, and its fierce pride almost make one believe that the young Joyce is the Dean reincarnate". Pero aunque Joyce fuera el último imitador de Swift, se puede rastrear su influencia en la poesía satírica de

\footnotetext{
${ }^{6}$ "T Two of the most famous personal satires which do survive are reputed to have caused the deaths, not of their victims, but of the satirists" (Mercier 134).
} 
autores contemporáneos como Austin Clarke y Patrick,Kavanagh, y la de Joyce y estos últimos en la de poetas más modernos como Thomas Kinsella y Paul Durcan quienes, con diferente enfoques, seleccionan en sus puntos de mira los mismos objetivos que sus antecesores: la Iglesia Católica y el Estado en Irlanda. La sátira contemporánea irlandesa "keeps denouncing, provoking, alarming, but we have the impression that the anti life forces, so powerful in Irish History and Literature, are beginning to disappear little by little" (Praga "Poetry and Satire" 82 ). 


\section{2. A. Clarke y las Instituciones: La Iglesia Católica.}

En 1955 reaparece con Ancient Lights, poemario que le devolvió de nuevo a los cauces literarios de Dublín. Después de dejar en los recovecos de la memoria la época medieval, y una vez superada la angustia existencial de Night and Morning, Clarke vuelve con un estilo y una voz poética diferentes, que estrena en una obra cargada de poemas autobiográficos $\mathrm{y}$, principalmente, de sátiras dirigidas contra la sociedad, el Estado y, sobre todo, contra la Iglesia Católica. A este poemario le seguirían otros cuyos contenidos tendrían una estructura similar.

No es de extrañar, por tanto, que tres de las colecciones de poemas que escribe a partir de 1955 estén subtituladas "Poems and Satires", y contengan el mayor número de poemas satíricos de toda su obra. Clarke, no obstante, seguiría escribiendo sátira hasta A Sermon on Swift and Other Poems (1968), pero no tan abundante. Todas sus colecciones incluyen tanto poemas cortos como largos poemas autobiográficos. Los primeros muestran una sociedad dominada por una Iglesia excesivamente conservadora; los segundos mezclan aspectos sociales y económicos de la sociedad con apuntes de su vida. En palabras de Schirmer,

These poems ... also attack aspects of modern Ireland familiar to most western nations in the twentieth century -the spread of suburban development, for example, and the destruction of the natural environment. ... These poems also question the assumptions that lie behind these developments: the notion that material gain and "progress" are of overriding importance, and the concurrent rejection of less tangible, but more humanistic values, especially human love. (PAC 68) 
Una vez identificadas las víctimas contra las qụe dirigirá Clarke su sátira, concentrémonos en su estilo. Como dijimos anteriormente, Clarke bebe de las fuentes de Swift, y en su poema "A Sermon on Swift" (457-60), no solo se identifica con él, sino que "[he] regarded Swift as a literary ancestor" (Garrat, “Aware”, 92):

In prose, plain as pike, pillory, In octosyllabic verse turning the two-way

Corner of rhyme, Swift wrote of privy matters

That have to be my text. (69-72)

Pero aunque Clarke y Swift compartan el mismo interés por el tipo de víctima hacia la que dirigen sus invectivas ${ }^{7}$ - la Iglesia y el Gobierno irlandeses que oprimen a la sociedad - sus sátiras son distintas en énfasis y fuerza. La sátira de Swift era implacable; la de Clarke, en cambio, se ha puesto en entredicho, incluso él mismo admitió en las notas a Collected Poems (1974) que su primer poemario satírico - Ancient Lights - contenía una sátira blanda que intentaría enmendar en el segundo volumen: "In their notices of Ancient Lights: Poems and Satires. First Series, a few critics suggested that some of the pieces were too mild to be called satires. I hope that I have made amends" (549). Richard Loftus opina que su sátira más tardía es impresionante, y lo que la hace ser así es la extraordinaria rabia que la conforma (277).

\footnotetext{
${ }^{7}$ Swift tenía un alto cargo dentro de la Iglesia Anglicana y era un Tory, es decir, conservador tanto en el ámbito religioso como político. Clarke era un escéptico y mantuvo siempre un enfrentamiento con su origen católico de clase media. Era, al contrario que Swift, un liberal tanto en lo religioso como en lo político (Garrat, “Aware" 99).
} 
Estilísticamente sigue la misma estrategia que Swift a la hora de componer sus sátira: ambos proceden de forma reduccionista, a menudo a través de la degradación del objeto y de la exposición de los defectos o vicios de la víctima. Normalmente, presentan el objeto o víctima al principio del poema; luego, desarrollan la situación en la que se encuentra la víctima, poniéndola en ridículo o reduciéndola al absurdo, $\mathbf{y}$, finalmente, concluyen el poema con una ocurrencia irónica sobre la víctima.

La sátira de Clarke es casi siempre de tipo punitivo, y está dirigida a castigar a sus víctimas por sus acciones o comportamiento. No están escritas en clave de humor, ni pretenden cambiar la opinión del lector. La sátira de Clarke muestra, con algunas excepciones, cuadros amargos sobre la forma en que el poder de las instituciones irlandesas regulan y controlan la condición humana de los individuos que integran la sociedad. Clarke no expone a sus víctimas para que el lector se regodee, sino para castigarlas:

The clergy are castigated for building new churches and seminaries, for neglecting their religious duties, for staffing State-run homes - voluntary-for unmarried mothers, for their social teaching, for surrounding the poet's house at Templeogue with religious convents, for going on foreign missions, for encouraging the erection of statues and grottoes, for their educational practices, even for their celibacy. (Martin, "Rediscovery" 429).

Loftus subraya la misma idea al hablar del propósito de la sátira de Clarke, "for the purpose of such satire is not to please men but to castigate them" (275), y, en este 
caso, los hombres a los que castigan pertenecen a la Iglesia Católica o al Estado irlandeses.

En su poesía, Clarke manifiesta un desmedido rencor hacia la Iglesia Católica y sus instituciones. Podría verse como razón principal el episodio que le ocurrió durante la confesión cuando tenía siete años y en la que el sacerdote le preguntó despiadadamente "if [he[ had ever made [himself] weak" (Clarke, $B C$ 130). Clarke no sabía a qué se refería y, desesperado, contestó que sí. Y aunque no pareció afectarle, el mismo Clarke confiesa que "it was not until later that the effects of this tampering reached too far within me" (130). La verdadera razón, sin embargo, la cuenta el propio Clarke en sus memorias. Cuando trabajaba como profesor auxiliar en University College, Dublin, Clarke se enamoró de una joven escritora $^{8}$ con la que decidió casarse secretamente sin el consentimiento de la Iglesia. Esto le ocasionó numerosos problemas. La Iglesia empezó a indagar en el asunto y, según recuerda Clarke en TRBC,

We were informed that we must state the church which we had attended for one month before the date of our intended union or cause to be published in a local newspaper the name of the house or houses at which we had knelt in private worship. We chose the first alternative, which seemed to us quite safe, but in a few days anxious clergymen were hurrying to the flat in which Margaret was living. (87-88).

\footnotetext{
${ }^{8}$ La mujer se llamaba Margaret y era una ferviente admiradora de James Joyce. Estaba escribiendo una novela llamada The Portrait of the Artist as a Young Woman (TRBC 87; cf. Thompson 110).
} 
Aparte de las razones que mencionábamos en el Capítulo II, está claro que la mente de Clarke no podía sobrellevar la tensión que todos esos avatares le produjeron:

The Clergy's proscriptions against masturbation, premarital sex, contraception, and divorce drove Clarke mad, ruined his marriage, kept him from obtaining a divorce, made it difficult for him to form liaisons with Irish girls, and put off remarriage and parenthood until after the death of his first wife. (Frazier, "The Cod-Bewildered" 58)

El mismo Clarke en unas líneas de "Old Fashioned Pilgrimage" $(355,62)$, un poema de 1967, describe su frustrado matrimonio con Margaret y reflexiona: 'O could the Church have allowed us pessary, thin cover, / I would not so abuse what others coveted' (107-108), versos que transmiten la idea de que si la Iglesia no lo hubiese tratado de forma tan cruel, él seguramente no se habría dedicado a satirizarla.

En los poemarios anteriores a 1955 , Clarke plasmaba el conflicto entre la Iglesia y el individuo desde una perspectiva personal: era su conciencia, a través de diversas máscaras, la que se enfrentaba a los dogmas de la Iglesia. Después de la terrible contienda que libró nuestro poeta en Night and Morning, Clarke liberó su mente de toda culpa, pero la Iglesia era la misma y la sociedad irlandesa en general seguía siendo la víctima indefensa de las arbitrariedades de una institución puritana y conservadora. Creemos, por tanto, que es necesario tener presentes algunos aspectos de la Iglesia Católica de Irlanda para comprender mejor la poesía satírica de Clarke. 
El principal papel de la Iglesia Católica en Irlanđa ha sido el de dirigir con mano férrea la vida irlandesa a través de los estrechos caminos del rigor puritano?. En la segunda mitad del siglo XIX, la celebración de la misa se regularizó, y se introdujeron nuevas devociones: rosario, novenas, adoración perpetua, bendiciones, peregrinajes, procesiones, etc. También surgieron organizaciones religiosas compuestas por hombres o por mujeres - cofraternities y sodalities $-\mathrm{y}$ se construyeron nuevas iglesias, de forma que la jerarquía eclesiástica se sentía segura dentro de su posición en la Iglesia Católica.

La razón que explica esta devoción se encuentra en el papel que jugó la Iglesia Católica en la confección del sentido de identidad nacional del país, porque el hecho de ser católicos les diferenciaba claramente del resto de la gente de las Islas Británicas. El Catolicismo había estado presente en la cultura irlandesa desde el siglo V aproximadamente, lo que establecía un importante nexo cultural entre la tradición gaélica y la dura represión de los siglos XVII y XVIII, en los que la fe católica yacía proscrita. El Catolicismo, por tanto, se asoció fuertemente con el sentimiento nacional $\mathrm{y}$,

\footnotetext{
${ }^{9}$ Es importante apuntar, aunque sea brevemente, las principales diferencias entre la Iglesia Católica irlandesa y la de otros países católicos europeos. Entre ellas tenemos el alto grado de adherencia institucional hacia la Iglesia, la persistencia de muchas prácticas mágicas y devotas, y la consideración de la Iglesia como la guardiana de la moralidad. Además, como observa Tom Inglis, estudios recientes han mostrado que "the weekly attendance at church by the Irish ( 83 per cent) was found to be three times higher that the general European average ( 25 per cent), and twice as high as traditionally Catholic countries such as Spain ( 41 per cent) and Italy (36 per cent) where the proportion of Catholics in the population is also nine in ten" (Moral Monopoly 32).

La extrema adherencia institucional hacia la Iglesia ha sido asimismo apuntado por Rosa González, que destaca el desmesurado respeto y lealtad hacia la jerarquía eclesiástica incluso en situaciones en que las ideas de ésta eran rechazadas o ignoradas ("Religion and Power in Ireland" 105).
} 
Few efforts were required in the twentieth century to develop Catholicism as a mark of national distinctiveness; the Church was incontrovertibly part of Irish reality and the practice of religion an evident feature of national life. (Brown, Ireland 29-30)

Desde que se constituyó el Estado Libre Irlandés - Irish Free State- el gobierno mantuvo a la jerarquía católica alineada a su lado, y ésta, a cambio, le prestó su apoyo y ayuda durante los aciagos días de la Guerra Civil. Sin embargo, durante los primeros años de gobierno, la Iglesia mostró cierto pesimismo ante su futuro, debido principalmente al clima de inseguridad que se respiró durante el periodo de 1912-23, y que colocó a la jerarquía eclesiástica en una difícil posición política. Durante la Guerra Civil, los obispos se habían opuesto a los republicanos, y ofrecieron su ayuda al gobierno del Estado Libre ${ }^{10}$, lo cual hizo que la Iglesia albergara sus dudas en cuanto a la fidelidad del pueblo. Éstas no tardaron en disiparse porque la mayor parte de la población permaneció fiel a sus creencias católicas.

Cosgrave, que fue primer ministro en las tres legislaturas en que gobernó su partido (de 1923 a 1932), no dudó en dejar que la jerarquía se pronunciara sobre la moralidad de la nueva legislación. La influencia religiosa fue un factor importante que no se podía pasar por alto: la Iglesia estaba firmemente decidida a retener su

\footnotetext{
${ }^{10}$ La Iglesia Católica siempre ha estado de parte de aquellos grupos que anhelaban la libertad política de Irlanda, y siempre ha condenado el uso de la violencia, independientemente de quien la esgrimiera. A su vez, cualquier grupo o facción política que recurriera a la violencia para lograr sus objetivos no dudaban en considerarse buenos católicos. Un buen ejemplo lo constituye el partido republicano de Fianna Fail que, a pesar de haber sido condenados por la Iglesia durante la Guerra Civil, no titubeó en mantener la autoridad de la jerarquía católica y concederle un puesto especial en la Constitución de 1937 (Rosa González, "Religion and Power in Ireland" 105).
} 
autoridad en asuntos de salud, bienestar y educación. En 1921, advirtió claramente al gobierno de que sería únicamente la Iglesia Católica la que se encargaría de la educación:

We wish to reassert the great fundamental principle that the only satisfactory system of education for Catholics is one wherein Catholic children are taught in Catholic schools by Catholic teachers under Catholic control ${ }^{\text {II }}$.

De este modo, tanto en educación como en asuntos sociales, el gobierno siguió la línea católica: "divorce was excluded, birth control outlawed, and the $\mathrm{Ne}$ Temere $^{12}$ decree enforced Catholic conditioning on children of mixed marriages" (Foster, Modern 534). Sin embargo, la jerarquía eclesiástica y el gobierno no estuvieron siempre de acuerdo en cuanto a asuntos morales se refiere. El gabinete de Cosgrave se mostró cauto al poner en práctica las peticiones de regulación social más radicales que provenían del clero y de un floreciente movimiento de Acción Católica, y no llegó nunca a decantarse por una postura firme en cuanto al divorcio. Tampoco se mostró firme en cuanto a la regulación de la prostitución. En 1926 hubo una alta incidencia de casos de sífilis, y un prominente Jesuita (Fr. S. R. Devane) pidió que no sólo se multara a las prostitutas sino que se las encarcelara también. El gobierno volvió a mostrarse indeciso, pero al final pasó por alto la advertencia y dejó sin alterar la ley (Fitzpatrick 227).

\footnotetext{
"Citado en Foster, Modern Ireland 1600-1972, 534.

12 "Decreto de 1564, reimplantado por la jerarquía católica irlandesa en 1908, por el que se considera nulo y sin efecto cualquier matrimonio mixto, especialmente entre católicos y protestantes, a menos que éste haya sido celebrado por la Iglesia Católica" (Hurtley et al. 225).
} 
Durante los años veinte, la Iglesia ejerció su autoridad para predicar una estricta moralidad y denunciar cualquier desarrollo social, político o económico que pudiera amenazar su código de valores. Lógicamente, la jerarquía se vio escandalizada por la amenaza que suponían el cine, los periódicos ingleses, las revistas, los bailes y las provocativas modas femeninas que se ponían cada vez más de moda. Se hacía imperioso apartarse de cualquier fuente de pecado. Una pastoral que publicó la Iglesia Católica en 1927, ilustra perfectamente los propósitos eclesiásticos ${ }^{13}$ :

These latter days have witnessed, among many other unpleasant sights, a loosening of the bonds of parental authority, a disregard for the discipline of the home.... The evil one is ever setting his snares for unwary feet. At the moment, his traps for the innocent are chiefly the dance hall, the bad book, the indecent paper, the motion picture, the immodest fashion in female dress - all of which tend to destroy the virtues characteristic of our race. (Brown, Ireland 40)

Las pastorales de los obispos solo tenían una idea central: combatir el declive de moral sexual que habían advertido en los nuevos tiempos:

In recent years the dangerous occasions of $\sin$ had been multiplied.... The actual hours of sleep had been turned into hours of debasing pleasure. ... Parental control had been relaxed, and fashions bordering

\footnotetext{
${ }^{13}$ Aparte de su obsesión por el sexo, el desmesurado puritanismo de I a Iglesia Católica se debía también a otras razones. Para Margaret O'Callagan, el principal motivo era el de "reassert their authority in an area that was now their only real domain - the field of faith and morals-; para Lee (42-3), en cambio, la verdadera razón se acercaba más a lo económico que a lo religioso. De hecho, Clarke condena en sus sátira el materialismo desmesurado que ostentó la Iglesia durante su época.
} 
on indecency had become a commonplaçe; while bad books, papers and pictures were finding their way into remote country places ${ }^{14}$.

Hacia finales de la década de los años veinte, el gobierno de Cosgrave se tambaleaba, y su debilidad fue pasto de quejas cada vez más fuertes que exigían que aplicara un control de moralidad más estricto. En 1931, la Iglesia Católica publicó veintiséis pastorales episcopales especialmente elocuentes: doce reafirmaban la santidad del matrimonio y rechazaban el divorcio; once deploraban los malignos efectos de la prensa, la radio, y la literatura; ocho criticaban el cine y el teatro; seis advertían de los peligros de bailar; cuatro mencionaban la anticoncepción y el aborto; tres condenaban los cortejos entre parejas (cf. Fitzpatrick 228). A todo esto hay que añadir la contribución estatal con la Ley de Censura de Publicaciones de 1929-Censorship of Publications Act-, y la obligación que sentía el poder legislativo de proteger la vida irlandesa de "impure external influences" (Brown, Ireland 70). Como es de prever, la fatal consecuencia de esta desastrosa política centrada solamente en la moral fue la de sumergir a la población irlandesa en una gran pobreza cultural, que se vería reforzada por la imposibilidad de conseguir libros de fuera.

Al ganar las elecciones el partido de de Valera, Fianna Fáil, la jerarquía eclesiástica vio temblar los pilares de su poder, porque una década antes había excomulgado en una pastoral a los Irregulares $^{15}$ del IRA. De Valera y otros

\footnotetext{
${ }^{14}$ Esta cita proviene del Irish Catolic Directory, 1928, 605 (20 Sept. 1927), citada en White, 25.

15 El IRA (Irish Republicna Army) se escindió en dos facciones después de la Guerra de Independencia contra Inglaterra: el "IRA Antiguo", formado por los que aceptaban el Tratado, y el
} 
republicanos, sin embargo, se habían cuidado de mantener buenas relaciones con miembros del clero que estaban fuera de la jurisdicción de la jerarquía eclesiástica, y convenció a sus seguidores de su deseo de respetar la autoridad espiritual de la Iglesia y de promover la moralidad tanto en la vida pública como privada. La jerarquía católica apoyó a Fianna Fáil, que ganó las elecciones de 1931 con de Valera al frente del partido. Esta aceptación se simbolizó durante el Congreso Eucarístico de Dublín en Junio de 1931 (al que Clarke dedicaría un poema satírico, como veremos más adelante). Una vez instalado en el poder, de Valera sobrepasó al partido de Cosgrave, Cumann na nGaedheal, en cuanto a la aplicación de reglas de moralidad. En febrero de 1935, el gobierno reforzó la campaña clerical contra la desidia moral de la época ${ }^{16}$ y prohibió los bailes sin licencia; además, siguiendo las indicaciones del sacerdote Devane, una enmienda al Código Penal permitía enviar a prisión a las prostitutas y prohibía la importación y venta de anticonceptivos que, como dijimos anteriormente, habían sido legales hasta este año. La constitución de 1937, redactada en su mayor parte por Jesuitas y otros consejeros eclesiásticos, confirmaba legalmente las pautas por las que se regía el código moral de de Valera. En su artículo $44.1 .2^{\circ}$, declaraba que, "the State recognises the special position of the Holy Catholic Apostolic and Roman Church as the guardian of the

\footnotetext{
"IRA Nuevo" que estaban en contra. "Estas dos facciones se enfrentaron después, como Ejército del Estado Libre (Free State) e Irregulars, respectivamente, en la guerra civil de 1922, en la que triunfaron los primeros" (Hurtley et al. 157).

${ }^{16}$ Durante los años de después de la Gran Guerra, tanto en el Estado Libre como en Irlanda del Norte, Gran Bretaña y los Estados Unidos, se creó un amplio sentimiento de colapso moral, seguido de una fuerte presión política para que se legislara con medidas restrictivas (Fitzpatrick, The Two Irelands1912-1939 227).
} 
Faith professed by the great majority of its citizens" (Fitzpatrick 230). Ésta era, por tanto, la Iglesia contra la que Clarke se reveló y que retrató en sus poemas satíricos.

"The Envy of Poor Lovers" (205) es un excelente poema para comenzar porque marca una elegante transición entre "Penal Law" y "Her voice Could not Be Softer" de Night and Morning y el resto de los poemas satíricos de Ancient Lights. Da la sensación de que los poemas se hubieran escritos uno detrás de otro, y que el lapso de diecisiete años que media entre ellos sea tan solo un capricho del destino. El poema retoma el viejo conflicto entre el deseo natural y los dogmas de la Iglesia. Clarke ataca de forma suave pero directa la extrema actitud puritana de la Iglesia Católica hacia el sexo, y, específicamente, el rechazo de ésta a admitir cualquier forma de control de natalidad artificial. Igual que en los dos poemas mencionados, los protagonistas son una pareja que esconde furtivamente su amor a los ojos de la sociedad y de la Iglesia,

Pity poor lovers who may not do what they please

With their kisses under a hedge, before a raindrop

Unhouses it; (1-3)

y cuyas aspiraciones no son ni estridentes ni escandalosas, simplemente anhelan lo que cualquier otra pareja casada. La mujer envidia algo tan ordinario y doméstico como echar las cortinas del dormitorio y su derecho legal a llevar el nombre de su marido: "happy position that could change her name" (6); el hombre ansía ese "clasp", ese broche que une al hombre y a la mujer y les permite vivir bajo el 
mismo techo y fundir sus naturalezas en el placentero abrazo del amor sin necesidad de sentirse culpables: "His envy — clasp of the married whose thoughts can be alike, / Whose nature flows without the blame or shame" (7-9).

El sigilo con que intentan consumar su amor al aire libre - "under a hedge" no garantiza ninguna intimidad- es un elemento esencial de la puesta en escena del poema. Los dos amantes simultáneamente se besan y tiemblan de miedo:

Lying in the grass as if it were a sin

To move, they hold each other's breath, tremble,

Ready to share that ancient dread - kisses begin Again - of Ireland keeping company with them. (10-13)

La situación no deja de ser, si no ridícula, sí exagerada, y provoca la sonrisa del lector: dos jóvenes debajo de unos arbustos sin apenas respirar para que no los descubran. Pero ese efímero esbozo de sonrisa se convierte pronto en mueca de desencanto, al notar el lector que la pareja se esconde porque sus acciones llevan el sello no sólo de la censura del código de la Iglesia sino también del de la sociedad.

Clarke tensa su ballesta y dispara sus afilados dardos satíricos en la última estrofa:

Think, children, of institutions mured above

Your ignorance, where every look is veiled,

State-paid to snatch away the folly of poor lovers

For whom, it seems, the sacraments have failed. (14-17)

"Institutions" se refiere a los orfanatos donde se lleva a los niños nacidos ilegítimamente. "Snatch away" y "folly" son palabras que degradan la dignidad que podría haber en llevar a un orfanato a un recién nacido que hubiera perdido a 
sus padres. En este caso, sin embargo, lo que hacen el Gobierno y la Iglesia es "arrancar" el "capricho" de los brazos de los padres y colocarlo en una institución financiada por el Estado. El léxico que usa Clarke no es en absoluto baladí: para la Iglesia el acto de amor de los jóvenes ha engendrado un simple capricho que ésta les arrebata sin el debido consentimiento paternal. La última línea del poema es un duro ataque de Clarke a la Iglesia y su doctrina, "For whom, it seems, the sacraments have failed", y una denuncia contra una actitud carente de toda consideración hacia la dignidad humana.

"Living on Sin" (271) es asimismo un poema en el que Clarke pasa por el tamiz de su fina sátira a las instituciones financiadas por el estado - "state-paid" institutions. Temáticamente, es una continuación de "Her Voice Could not Be Softer": aquel "hasty sin" cometido por la joven pareja ha engendrado una criatura que dará un "trabajo" a las monjas que trabajan en una de estas instituciones:

The hasty sin of the young after a dance,

Awkward in clothes against a wall or crick-necked

In car, gives a nun her tidy bed,

Full board and launderette. God-fearing State

Provides three pounds a week, our conscience money,

For every infant severed from the breast.

El primer síntoma de ataque satírico se encuentra en el título. Según Maxton, el título comprende dos expresiones: living in sin, que significa cohabitar fuera del matrimonio, y living on $\sin$, que es el delito con el que se acusa a prostitutas y proxenetas (221). Pero en este caso no tenemos a ninguna pareja viviendo fuera del 
lazo matrimonial, sino a la criatura que concibió una pareja y que está al cuidado de unas monjas. Por tanto, nos queda solamente la segunda expresión que, en este contexto, es particularmente hiriente, sobre todo porque va dirigida a las monjas del orfanato, dando a entender que las monjas que trabajan con niños ilegítimos en orfanatos católicos están ganándose un salario a costa de los pecados ajenos.

Como es habitual en su método satírico, Clarke introduce los blancos de su sátira, la Iglesia y el Estado que mantienen los orfanatos, y luego ataca sus puntos de vista o sus acciones por medio de un artificio retórico: tanto el hecho de que los pecados de los demás den trabajo a las monjas como el "hurto" de la criatura del pecho de la madre son exageraciones degradantes que exponen la verdad satírica que, en este caso, es la falta de humanidad de ambas instituciones. Schirmer, sin embargo, cree que Clarke está juzgando la labor humanitaria de las monjas de forma despiadada ya que "[Clarke] ignores so cruelly the often unselfish motives of nuns in these institutions" (PAC 78), lo cual hace que la sátira se convierta en pura controversia. Agustin Martin piensa de igual forma:

An example of his unfairness occurs when he accuses the nuns who devote their lives to the care of unmarried mothers in voluntary Magdalen Homes of looking for a 'tidy bed / Full board and laundrette free'. Anyone who knows the reality of the case is aware that most of the nuns concerned come from Irish middle-class homes and sacrifice much more tempting comforts than these rather basic amenities - not after all, a staggering return for a life of seclusion, service and celibacy. ("Rediscovery",431) 
Nosotros no estamos de acuerdo, y creemos que el objetivo del poema no son precisamente las monjas, sino el hecho de que la Iglesia y el Estado actúen en total connivencia y no duden en separar a un hijo de sus padres solamente porque éste ha nacido fuera de los lazos matrimoniales. No interpretamos que Clarke ataque a las monjas en sí, sino la falta de humanismo de las instituciones hacia los padres - casados o no- y hacia el recién nacido. El hecho de que les haya tocado a las monjas ser el último eslabón de la cadena administrativa de ambas instituciones no implica que las monjas estén de acuerdo con la política social de sus superiores. La sátira no va contra ellas: sería tanto como acusar al soldado cuyos mandos le obligan a fusilar a un soldado enemigo.

Quizás parecería que Clarke está obviando a aquellos que reciben el castigo por su pecado si no fuera por ese metonímico "launderette" que alude a las madres solteras que se encontraban en la obligación de tener que trabajar para sustentarse. En "Unmarried Women" (272), otra descarnada sátira contra la Iglesia Católica y la sociedad, Clarke muestra el destino de las mujeres solteras embarazadas en una Irlanda que castiga a la mujer mientras el hombre queda completamente absuelto. Da la sensación de que la única parte culpable de un embarazo fuese la mujer. La comparación que se establece entre el representante de la Iglesia y las pobres mujeres que tienen que trabajar en el convento funciona como artificio retórico para degradar y ridiculizar la actuación eclesiástica:

In the Convent of the Sacred Heart, The Long Room has been decorated 
Where a Bishop can dine off golden plate:

As Oriental Potentate.

Girls, who will never wheel a go-cart,

Cook, sew, wash, dig, milk cows, clean stables (1-6)

Las riquezas del Obispo contrastan abruptamente con la pobreza de las mujeres -las "launderette" del poema anterior- y las agotadoras tareas domésticas. Las mujeres trabajan y tienen además que dar de mamar a su hijos: "And, twice a day, giving their babes / The teat, herdlike..." (7-8). Esta cruda comparación se ve apoyada por un léxico que, unas veces exagerado, otras ridículo, pone de manifiesto los vicios y defectos de su víctima: el obispo cuya opulencia se trasluce a borbotones en "golden plate" y "Oriental Potentate"; y en el polo opuesto están las madres solteras sin derecho alguno a reclamar. "Herdlike" degrada la acción natural de dar de mamar; "When their skirts were tossed up / above their haunches" (9-10) muestra la violencia del acto amoroso, y acentúa la violencia de una sociedad que tiene poca o ninguna consideración hacia la mujer.

La sociedad, además, no parece ofrecer muchas salidas para estas mujeres que han "caído" fuera de la gracia de Dios. Clarke muestra dos de los posibles caminos que puede seguir una madre soltera en Irlanda: el de su degradación física trabajando como una esclava en un convento para poder alimentarse así misma y a su hijo, o el del exilio, como bien evidencian las dos últimas líneas del poema:

Luckier girls, on board a ship,

Watch new hope spraying from the bollard. (12-13) 
Hay, sin embargo, otra salida que no se menciona ni explícita ni implícitamente en el poema: el matrimonio.

Pero el matrimonio no es una garantía; éste, igual que toda la vida social del individuo, está controlado por la Iglesia Católica. Tampoco significa que todo esté permitido dentro de él. Durante la mayor parte del siglo XX, el control de natalidad estaba poco menos que proscrito, por lo que la gente casada tenía que seguir el viejo mandato bíblico de "creced y multiplicaos" o evitar embarazos no deseados a través de método naturales que, aparte de no ser infalibles, tampoco eran muy bien vistos por la Iglesia, como muestran las líneas de "Marriage" (196).

Aquí, Clarke satiriza la posición de la Iglesia sobre la anticoncepción, y lo hace rebajando su actitud hacia ésta. El poema empieza con un comentario humorístico sobre esas familias numerosas en las que la intimidad apenas existe, y en las que los métodos naturales de control de natalidad cargan a los padres con más hijos de los que pueden alimentar. Al estar prácticamente hacinados, los padres no pueden compartir momentos de intimidad sin que sus hijos les oigan:

Parents are sinful now, for they must whisper

Too much in the dark. Aye, there's the rub! (1-2)

El adjetivo "sinful" y el verbo "whisper" matizan la furtiva y empobrecida sexualidad que practicaba la gente de la generación de Clarke, la cual tenía que,

...try to be chaste

And when they cannot help it, steal the crumbs

From their own wedding breakfast, spare expense

And keep in warmth the children they have nourished. (4-7) 
A medida que avanza el poema, la sátira de Clarke se afila y se concentra en el sacramento del matrimonio:

But shall the sweet promise of the sacrament

Gladden the heart, if mortals calculate

Their pleasures by the calendar? $(8-10)$

La degradación de "sweet promise of the sacrament" junto con la forma de calcular el placer mediante el calendario - periodo de la mujer - conduce al lector a las imágenes finales, que muestran cómo las doctrinas de la Iglesia llegan incluso a crear un complejo de culpabilidad dentro del matrimonio si la mujer no se queda embarazada:

....Night school

Of love where all, who learn to cheat, grow pale

With guilty hope at every change of moon! (10-12)

El verbo "to cheat" degrada la vida en pareja al mostrar a los padres tratando de eludir las leyes del código moral de la Iglesia y así evitar un embarazo no deseado. De igual modo, la situación ridiculiza el romanticismo que siempre ha tenido la luna, y que en este caso solo sirve para calcular el periodo de menstruación de la mujer.

Aparte de métodos naturales, que la Iglesia tampoco veía con agrado, otra solución era usar anticonceptivos para evitar que la mujer se quedara embarazada. "Precautions" (255) ataca directamente la estricta moralidad de la Iglesia sobre la planificación familiar, al igual que lo hace "The Pill" (377), escrito unos años más 
tarde. El primer poema es un furioso ataque dirigido contra los eruditos de Roma ${ }^{17}$ sobre la anticoncepción ${ }^{18}$. Ésta fue declarada proscrita en el Estado Libre mediante la Enmienda a la Ley de Enjuiciamiento Criminal de 1935 -Criminal Law Amendment Act-, y cualquier información que hubiera sobre ella había sido clasificada como "literatura indecente" por la Ley de Censura de Publicaciones de $1928^{19}$. No fue hasta 1960 cuando se permitió que los médicos prescribieran la píldora anticonceptiva para regular la menstruación; sin embargo, muchos católicos se mostraron cautelosos a la hora de usarla por miedo a la Iglesia, miedo que quedaría reforzado por la encíclica papal de 1968, Humanae Vitae. A partir de 1974, la Corte Suprema Irlandesa permitió la importación de anticonceptivos, y la Ley de Planificación Familiar - Health (family Planning) Act - legalizó su venta y distribución en 1979.

En "Precautions", Clarke ataca la falta de coherencia de la jerarquía eclesiástica, que aplica sus leyes de forma arbitraria, permitiendo que las monjas misioneras que están en África puedan tomar la píldora anticonceptiva en caso de violación. Clarke ridiculiza esta regulación de forma despiadada:

These scholars are modestly selective

Who say our nuns in Africa, (1-2)

\footnotetext{
${ }^{17}$ Clarke, en sus notas a CP (1974), hace el siguiente comentario: "Monsignor Lambruschini of the Pontifical Lateran University; Fr. F. Hust, S.J., of the Gregorian University, Monsignor Palazzini, Secretary of the Vatican Concilier Congregation. Their recent conclusions, which seem cynical, were printed in Studi Cattolici and reported in English and American newspapers, but suppressed here. Apparently Irish parents must not be warned of the danger to which their daughters may be subjected in remote regions" (553).

${ }^{18}$ La importación y venta de anticonceptivos había sido legal hasta 1935 (cf. Fitzpatrick, The Two Irelands 1912-1939 227).

${ }^{19} \mathrm{Cf}$. The Oxford Companion to Irish History 113.
} 
Can take an oral contraceptive,

An hour or two before the rape. (5-6)

La situación es evidentemente absurda: ¿cómo habrían de saber las monjas cuando las iban a violar? Irónicamente, Clarke pregunta: "How will they know dread time or place / That leaves the soul still full of grace?" (7-8) La falta de coherencia queda reforzada por la "modestia" con que los prelados eclesiásticos seleccionan a quienes pueden o no pueden tomar la píldora. Clarke implícitamente lanza la siguiente pregunta al aire, ¿por qué habrían de tener las monjas un derecho que no pueden tener las mujeres irlandesas?, y les recomienda que utilicen los mismos métodos que emplean las mujeres irlandesas - "Dutch cap or wad, syringe or douche"- o, simplemente, que confíen en Dios. Su sátira funciona al rebajar el comportamiento de las monjas misioneras al mismo nivel que el de las mujeres casadas de Irlanda.

El segundo poema, "The Pill", es una triste elegía que compuso Clarke en recuerdo de una sobrina suya, Ethelind, que murió al dar a luz, quedando su hija huérfana - "her babe / unmothered" (6-7). El poema empieza con una pregunta dirigida directamente a los prelados de la Iglesia: "Must delicate women die in vain / While age confabulates?" (1-2). El tono satírico lo provee la palabra "confabulates", que degrada la seriedad que deberían tener las discusiones de la Iglesia sobre la anticoncepción: "confabulate" es charlar, muy diferente de "discutir" o "hablar" sobre un tema. Pero, además, no charlan de forma clara, sino en susurros, ya sea para quitar importancia al asunto, ya por la propia naturaleza 
tabú del tema, o ya para crear la ambigüedad necesaria que evita una clara pronunciación sobre un tema tan escabroso para ellos:

Now prelates in the Vatican

Are whispering from pillar to pillar

Examining in Latin the Pill,

Pessary, letter, cap. (8-11)

Lo que es absurdo y ridículo es que una pareja tenga que estar a expensas de lo que "confabulen" algunos prelados del Vaticano sobre los métodos que han de usar sus feligreses en Irlanda. Clarke vuelve a preguntar:

...What can

We do until they have decreed

Their will, changing the ancient creed,

But lie awake on a separate pillow?

Y para rebajar más la actitud de los pontífices, Clarke los llama "nightly watchers of the womb" (16), con un marcado tono orwelliano: las parejas están metafóricamente observadas por la Iglesia, por un invisible "Gran Hermano" que vela por una sexualidad acorde con su código moral y, consecuentemente, por un adecuado control de natalidad. En estos poemas, vuelven a aparecer claramente diferenciadas dos víctimas: la Iglesia, que no logrará eludir la pluma de Clarke, y la mujer, a quien le es imposible zafarse del recio grillete eclesiástico. El hombre, en general, parecía estar más desprendido del férreo control del sacerdote, al contrario que la mujer que estaba prácticamente atada de pies y manos. 
En Irlanda, no sólo la Iglesia y la escuela sirvieron para desarrollar una rígida moral sexual. El pub también contribuyó a su desarrollo. Era el lugar donde los hombres se juntaban en grupos y desplazaban su frustración sexual mediante la bebida. En el pub mantenían su independencia del matrimonio y de la mujer. Ésta ejercía su control en el hogar; el hombre en el campo y en el pub. Pero además, el pub servía para escapar de la supervisión moral del clero y de la mujer (Inglis 180). ¿Por qué, entonces, era la mujer la víctima directa de la estricta moral de la Iglesia si ésta ya estaba bajo el control eclesiástico?

Desde mediados del siglo XIX, la figura de la madre irlandesa jugó un papel importante en el desarrollo social de Irlanda. Era ella quien estableció un vínculo entre la Iglesia Católica y el individuo, y la que introdujo el código moral de la Iglesia en el hogar. La madre representaba un poder moral tanto en la Iglesia como por mediación de ella porque se había establecido un nexo entre ella y el sacerdote, de quien obtenía la ayuda moral para llevar el hogar. Según Inglis, el desarrollo de la Iglesia y de una rígida disciplina moral no se hubieran conseguido a no ser por la madre irlandesa:

She became the sacred heart of the Irish home. It was she who inculcated a ritualistic and legalistic adherence to the rules and regulations of the Church. She brought the family to prayer and enforced the Church's code of morality. She was the Church's representative in the home who supervised the moral conduct of her husband and children. She became the living embodiment of Our Lady - humble, pious, celibate and yet fecund. (220) 
El que toda una sociedad esté centrada en la figura de la mujer como madre tiene sus raíces en una serie de informes parlamentarios de mediados del siglo XIX que indicaban que la civilización de la sociedad irlandesa dependía no solo de dar más poder a la Iglesia Católica, sino de transformar a las mujeres irlandesas en buenas madres. El retrato que ofrecía de la madre irlandesa la Poor Law Commission no se mostraba en absoluto halagador: "the unthrifty and dissolute character of the women" (Inglis, 199). No era, por tanto, una mera cuestión de enseñar a las jóvenes las típica tareas domésticas, sino que había que supervisarlas dentro del hogar. Esta tarea recayó en la Iglesia, que, a través de sacerdotes y monjas, empezó a definir las tareas de las madres dentro de la casa. Y una de las formas de conseguir esto era controlando su vida sexual:

In Ireland it was the knowledge and control that priests and nuns had over sex which helped maintain their power and control over women. Women were made to feel ashamed of their bodies. They were interrogated about their sexual feelings, desires and activities in the confessional. ...Sex became the most abhorrent sin. It was through the control of sex that the modern Irish mother and family was first established. (Inglis 199)

Hay que tener en cuenta que la tasa de matrimonios después de la Gran Hambruna de 1947 descendió drásticamente debido principalmente a factores económicos. Antes de esta fecha, la mujer compartía las tareas del campo con su marido, pero esto cambió después y afectó a la situación económica de la mujer, que pasó a depender más del marido y a tener que trabajar más dentro de casa que fuera de 
ella. Además, la dote que ella llevaba al matrimonio tenía que ser mayor, ya que su contribución laboral había cambiado.

A pesar de la emigración que se produjo en la segunda mitad del siglo XIX, la tasa de mujeres solteras era alta, y sus perspectivas de matrimonio bajas. Un granjero con dos hijas no podía darles dote a las dos, porque reduciría su poder adquisitivo al disminuir sus ahorros. En palabras de Lee, "Marriage might be a sacrament, but for the farmer the marriage contract was essentially a commercial transaction" ("Women" 39). Esto contribuyó a que no solo se demonizara eclesiásticamente el sexo, sino también socialmente, en especial porque representaba una amenaza para la seguridad de la familia. La Iglesia Católica contribuyó poderosamente a desterrar la tentación sexual de la mente femenina a través del poder que concedía a sus sacerdotes, y que estos ejercían sobre la mujer en el confesonario. Clarke nos lo muestra en una simple pero tremenda parábola de dicho poder ${ }^{20}$. "The Redemptorist" (379-80) muestra este poder en términos dictatoriales, e insiste en la falta de humanidad y compasión de la Iglesia Católica. Es un poema sobre "the violence done by an institution against a single, fragile, vulnerable woman" (Kennelly, "Poetry" 21). Esta vez, Clarke no nos presenta una situación absurda o ridícula; simplemente utiliza la figura del misionero como

\footnotetext{
${ }^{20}$ Esto empezó a cambiar a partir de los años sesenta porque las mujeres "began to acquire a knowledge of sex and a control over their bodies which has been instrumental in attaining economic and political power, thereby shattering the bonds that made them dependent on the moral power of the Church" (Inglis 221).
} 
metonimia del poder del clero sobre la madre irlandesa y como símbolo de la arrogancia de una Iglesia consciente de su tremenda autoridad:

'How many children have you?' asked

The big Redemptorist.

'Six, Father.'

'The last,

When was it born?'

'Ten months ago.'

'I cannot absolve your mortal sin

Until you conceive again. Go home,

Obey your husband.'

She whimpered:

'But

The doctor warned me...'

'No pregnancy. You'll die the next time,'

The Doctor had said. (23-24)

El sacerdote ha dictado su sentencia, y la pobre mujer obedece al cruel sacerdote el siguiente sábado por la noche. Es una sentencia de muerte, y el acto amoroso se convierte en el vehículo de su ejecución. Nueve meses más tarde, el orfanato se hizo cargo de sus hijos:

Her tiredness obeyed

That Saturday night: her husband's weight

Digging her grave. So, in nine months, she

Sank in great agony on a Monday. (25-28) 
El ataque satírico lo logra Clarke no solo mediante la descripción física del brutal misionero - "The big Redemptorist", "Red-bearded saint" - sino también a través de sus acciones:

While, proud of the Black Cross on his badge,

The Liguorian, at Adam and Eve's,

Ascended the pulpit, sulphuring his sleeves

And setting fire to the holy text. (31-34)

Éstas delatan a una persona soberbia que, junto con el tono autoritario con el que se dirige a la mujer y la arrogancia con que la despide del confesonario - "shutter became / her coffin lid" (13-14)—, ofrecen una amarga y desabrida visión de la falta de bondad e indulgencia del sacerdote católico - metonimia atroz de la Iglesia Católica. El poema es una muestra clara de "the destructive, evil guidance of Ireland's ignorant moralists" (Tapping 216). Clarke despiadadamente muestra la hipocresía de la Iglesia Católica, la cual engendra una violencia dirigida contra sus miembros, especialmente mujeres (Kennelly, "Poetry" 22).

Este poema sirve para mostrar la universalidad de algunos de los temas de la poesía de Clarke. Es verdad que muchos de sus poemas no trascienden las fronteras de su propio localismo, y los que le acusan de poeta local no yerran en su opinión. Pero a pesar de ello, sus poemas contienen las suficientes connotaciones humanas como para lograr que su poesía se universalice y se cargue de "indignation over the abuses of power and anger over the unreasonable pride of man" (Garrat, "Aware" 103). No sabemos lo que sugeriría "The Redemptorist" a un lector irlandés de los años sesenta, pero para el lector de finales del siglo XX, 
independientemente de sexo, credo o nacionalidad, el mensaje de Clarke no puede ser más claro y directo: la actitud del sacerdote católico constituye una total ofensa contra la sensibilidad humana y, sobre todo, contra los derechos humanos.

Clarke, en su primer volumen de memorias, cuenta la anécdota de una modista amiga de la familia, Mrs. Carney, que un día descubre que su marido le había estado ocultando el aumento de salario que recibía y que se lo gastaba en el pub con los amigos. Este hecho hizo que no le volviera a dirigir la palabra. Su ira fue tal que incluso la llevó a ignorar las amenazas del sacerdote: "In vain did the local clergy admonish her, point out that it was her duty to obey her husband, in vain did they warn her that such obstinacy might cause him to commit $\sin$ " (TRBC 113). En toda la obra de Clarke se observa una especial sensibilidad hacia la mujer, lo que revela su preocupación con "the long martyrdom of women throughout the centuries" (TRBC 114), preocupación que aflora en poemas como "Martha Blake at 51", "The Vocation", o "Miss Marnell", en los que satiriza y expone las fuerzas que someten a la mujer en Irlanda.

En estos poemas, Clarke castiga por igual a la Iglesia, al Estado y a la sociedad por la falta de humanidad y consideración que demuestran hacia el ser humano. Las protagonistas de estos poemas son personas solitarias, que viven en una pobreza casi absoluta, y que por un motivo $\mathrm{u}$ otro se sienten frustradas al no habérseles permitido disfrutar de la vida con algo más de dignidad. Son los representantes de la rutina existencial que asola la ciudad de Dublín. En palabras de Garrat, 
Life in modern Dublin is presented as a routine existence, recalling the sense of paralysis and death in Joyce's Dubliners. The people in Clarke's poems exist in a world described by spiritual paralysis, death-in-life, robot patterns of behaviour. ("Austin Clarke" 108)

"Martha Blake at 51" (265-270) es el relato de una mujer que ha vivido una vida miserablemente gris y ordinaria, y que muere sin un ápice de dignidad en una fría habitación de un hospital público bajo la indiferente mirada de una sociedad que supuestamente la cobijaba. Martha Blake aparecía en una poema homónimo anterior, "Martha Blake", que describía a una mujer cuyo fervor religioso constituía el aspecto más importante de su personalidad, y que comentamos en el capítulo anterior. Veinticinco años después, el rasgo distintivo de su carácter es la frustración. La primera Martha participaba del milagro de la comunión con júbilo y devoción inauditos, al mismo tiempo que aprendía a negar su cuerpo en beneficio de su alma; para la Martha del segundo poema, la comunión se ha convertido en una rutina más en su vida, y a fuerza de descuidar su cuerpo, éste se le ha vuelto en contra: "To her pure thought, / Body was a distress" (13-14). En el transcurso de un poema a otro, Martha ha estado librando una agotadora guerra entre su cuerpo y su alma, perdiendo aquél todas y cada una de las batallas. "Martha Blake at 51" nos muestra de forma rayana en la crueldad cómo el culto de Martha por su alma la ha arrastrado a la decepción y al desencanto, y el desprecio por su cuerpo a la muerte.

Clarke a través de una sutil técnica satírica, y con la ayuda de Martha Blake, mina las instituciones sociales y religiosas irlandesas, exponiendo su falta de 
humanidad y mostrando el lado feo y oscuro del hombre: su orgullo y su imperfección. Al igual que Swift, Clarke reduce al hombre a su naturaleza más básica, lo desnuda y deja al descubierto sus defectos, tanto psíquicos como físicos. En este poema, las enfermedades de Martha quedan al descubierto, pero no con la intención de ridiculizarlas sino de demostrar la triste recompensa de su extrema devoción. En ciertos momentos recuerda al famoso poema de Swift “A Beautiful Nymph Going to Bed", sobre todo cuando enumera los síntomas de su indigestión. Al final, el objetivo del satírico es demostrar lo que llamaba Rosenheim "the satiric truth", es decir, la verdadera esencia de todo lo que el hombre esconde detrás de sus máscaras sociales. Martha, a fuerza de negarle placer a su cuerpo, termina sus días sola, destrozada física y espiritualmente, en un hospital público, víctima de la más cruel desconsideración. En palabras de Susan Halpern, "she dies, unhappy, unloved, her religious sacrifices in vain" (97).

El poeta satírico gusta de moverse en lo que llama Brown "the margins of our consciousness" ("Austin Clarke" 134), es decir aquellos aspectos de la experiencia humana que no son centrales en la conciencia diaria. Así, las funciones excretoras y digestivas del cuerpo humano se convierten en materia prima para el satírico. Parece como si toda el material de deshecho de nuestro cuerpo existiera solamente en los ribetes de nuestra conciencia, y el satírico lo aprovechara - casi podríamos decir que lo reciclara - para ponerlo en el centro de atención del lector. Clarke se reafirma en Swift, maestro indiscutible de la exploración de estos 
territorios subversivos: "Our Lady of Filth, Cloacina, soiled goddes / Of paven sewers"21 $^{21}(44-45)$.

"Martha Blake at 51" no es un poema que parezca estar relatado, sino más bien rodado, en el sentido cinematográfico del término. El sufrimiento corporal y la aflicción espiritual de Martha son el hilo conductor del poema, que Clarke nos invita a seguir a través de su cámara poética. Las escenas del poema están construidas en torno a irónicos contrastes que muestran, por un lado, la separación del alma y el cuerpo, y por otro, las ilusiones de Martha y la cruda realidad que no consigue percibir.

En las siete primeras estrofas, la pluma cinematográfica de Clarke nos presenta a la devota Martha entregada a sus diarias obligaciones con la Iglesia y con su vida: como todas las mañanas asiste a misa y comulga; después, lentamente se dirige a casa donde desayuna frugalmente un huevo con un poco de té y pan y descansa. Todas estas acciones están relatadas en el pasado simple y dependen de las frases adverbiales con las que comienza el poema, "Early, each morning", que enfatizan lo cotidiano, lo repetitivo de unos sucesos que dejan de ser algo extraordinario, algo por lo que realmente vivir: "Walked", "knelt", "Bowed head", "took out her Yale key", "put a match to gas-ring", "Half-filled a saucepan", "rested", "drowsed". Clarke insiste en la rutinaria vida de Martha: "And purchased, daily, with downcast eyes, / Fillet of steak or a chop." (27-28).

\footnotetext{
${ }^{21}$ Del poema, "A Sermon on Swift" (457-460).
} 
A continuación, tenemos una escena en la que el,cuerpo de Martha se rebela furioso en desagradables imágenes que denotan su desastroso estado de salud, prosaicos detalles de su vida que no están normalmente en el centro de nuestra conciencia diaria, sino más bien en sus márgenes:

She suffered from dropped stomach, heartburn

Scalding, water-brash

And when she brought her wind up, turning

Red with the weight of mashed

Potato, mint could not relieve her.

In vain her many belches,

For all below was swelling, heaving

Wamble, gurgle, squealch. $(33,40)$

Estas líneas sacadas de contexto, provocarían la risa del lector, pero "the reader is soon aware that Clarke is not laughing - just describing" (Fitzgerald 17). Dentro del poema, el retrato de Martha mueve más a la compasión del lector que a la jocosidad; además, crea un sentimiento de recelo hacia las fuerzas públicas que han permitido el estado actual de la solterona de Rathgar Road. A pesar de su aparente tranquilidad de espíritu - ella confía plenamente en su fe religiosa-, su cuerpo se rebela y la atormenta: “...but still her daily food / Repeated and the bile / tormented her." (45-47) Incluso las estatuas y estampas que la acompañan en su soledad, parecen estar en desacuerdo con ella: "The Virgin sadly smiled" (48), y

When she looked up, the Saviour showed

His Heart, daggered with flame

And, from a mantle-shelf, St. Joseph 
Bent, disapproving. Vainly

She prayed for in the whatnot corner,

The new Pope was frowning. Night

And day, dull pain, as in her corns,

Recounted every bite. (49-56)

La Virgen sonríe triste, San José la reprocha desde el estante, el Papa frunce el ceño: ella reza en vano. La estrofa entera anticipa ya lo que será su abandono espiritual: su propia fe negándole el apoyo espiritual del que siempre ha dependido.

En las siete siguientes estrofas, Martha Blake concentra sus pensamientos en Santa Teresa de Jesús y San Juan de la Cruz, y en las experiencias místicas ${ }^{22}$ de éstos con Dios. Comienza pensando en Santa Teresa, pero la imagen que tiene de ella está completamente distorsionada. Así, por ejemplo, los demonios que atormentaban las visiones de Santa Teresa se transforman dentro de la ingenua conciencia de Martha en "Small black boys in their skin" (61), y la visión del infierno, que Santa Teresa describía como un lugar claustrofóbico, oscuro y tenebroso poblado por reptiles, en la confusa mente de Martha es simplemente,

...a muddy passage

That led to nothing, queer in shape,

A cupboard closely fastened. (62-64)

\footnotetext{
n Recordemos que para el místico lo importante es la experiencia extrema de la unión, y ésta es una categoría erótica: "La aspiración de un ser a fundirse con otro es unidad indisoluble constituye el movimiento primero del erotismo, cuando no de la pura sexualidad. La adoración introduce un elemento religioso en el erotismo, la unión un elemento erótico en la religión" (citado en Valente 45).
} 
De igual modo, la mística española describía las disonancias entre su cuerpo y su espíritu como radiantes uniones extáticas con Cristo. Martha no conoce las obras de la Santa ${ }^{23}$, cuyas experiencias se convierten en la mente de Martha en meras fantasías de una beata poco menos que iletrada. La estrofa undécima es particularmente irónica: Clarke reduce al ridículo la aversión católica de Martha por lo protestante:

Teresa had heard the Lutherans

Howling on red-hot spit, And grill, men who had searched for truth

Alone in Holy Writ.

So Martha, fearful of flame lashing

Those heretics, each instant,

Never dealt in the haberdashery

Shop, owned by two Protestants. (81-88)

Las dos últimas líneas son absurdas al mostrar la ingenua noción que tiene Martha de la religión. La estrofa "underlines the dichotomy between historical actuality and Martha's morality" (Harmon, $A C$ 195). El razonamiento de Martha no tiene ninguna base sólida sobre el que sustentarse; en realidad, solo demuestra una total desconexión entre sus ideas religiosas, rayanas en la ignorancia más destructiva, y el mundo real, que se encargará de hacer comprender a Martha, como veremos en la última estrofa del poema, cuál es el verdadero estado de su situación.

${ }^{3}$ Especialmente "the Way of Perfection and the Interior Castle which give positive instructions in the spiritual life" (Harmon, AC 194) 
Martha sigue con los místicos españoles en mente, y muestra la limitada comprensión que tiene sobre los textos que ha leído y la realidad en la que vive. Santa Teresa describe su unión con Dios en términos extáticos: un ángel atraviesa su corazón con una lanza que le penetra hasta sus entrañas. Al retirarla, la Santa se queda encendida y con un gran amor por Dios, y el dolor que experimenta es tan dulce que desea no perderlo. Martha Blake rememora en su imaginación la misma escena, solo que en ella la santa se desmaya de dolor y gozo mientras un dardo se mueve de arriba abajo dentro de sus intestinos, y sus células sudan como si se las hubiese frotado con una toalla. Martha es incapaz de comprender las experiencias místicas de Santa Teresa, y las imagina de forma tosca, burda, y con la falta de sensibilidad que revelan las siguientes líneas:

In ambush of night, an angel wounded

The Spaniard to the heart

With iron tip on fire. Swooning

With pain and bliss as a dart

Moved up and down within her bowels

Quicker, quicker, each cell

Sweating as if rubbed up with towels,

Her spirit rose and fell. (89-96)

En la siguiente estrofa, Clarke relata concisa y excelentemente la unión mística de San Juan de la Cruz acorde con el poema del santo, "Llama de Amor Viva":

Senses beyond seraphic thought,

In that divinest clasp, 
Enfolding of kisses that cauterize,

Yield to the soul-spasm. (101-104)

Martha tampoco puede comprender tal intensidad y, en vez del placer de la unión mística, experimenta terror y sofocos; en lugar de música celestial, sólo oye ruido. Para el místico, la culminación de la unión con Cristo produce un estremecimiento del alma; para Martha, en cambio, el momento extático es un simple desvanecimiento, que le provoca palpitaciones en vez de placer:

...Heart palpitates

And terror in her stiffens.

Heart misses one beat, two ..flutters ..stops.

Her ears are full of sound.

Half fainting, she stares at the grandfather clock

As if it were overwound. (106-111)

Sus fantasías místicas las interrumpe irónicamente un inoportuno malestar estomacal que le recuerda que su cuerpo no comparte la aparente salud espiritual de su alma. En realidad su cuerpo enfermo y maltratado desprecia a su alma:

The fit had come, Ill-natured flesh

Despised her soul. No bending

Could ease rib. Around her heart, pressure

Of wind grew worse. Again,

Again, armchaired without relief,

She eructated, phelgm

In mouth, forgot the woe, the grief,

Foretold at Bethlehem ${ }^{24}$ (112-119)

\footnotetext{
34 " 'The grief, / Foretold at Bethlehem', alludes to the incident reported in Luke 2:35, when Simeon prophesies to Mary, "And thy own soul a sword shall pierce, that out of many hearts, thoughts may be
} 
Estas dos estrofas niegan que la indigestión tenga algún paralelo espiritual con "the Virgin's grief or Teresa's visionary agonies" (Maxton 237), y la fina ironía satírica se encuentra no ya en la situación, que ya de por sí es ridícula - sus pensamientos místicos interrumpidos por una flema que casi la ahoga - sino en el vocabulario de la segunda estrofa: "fit", "Ill-natured-flesh", "despised" "wind", "eructated", "phelgm in mouth", palabras que coloca Clarke en el centro de la experiencia religiosa de Martha, pero que pertenecen a los márgenes de su conciencia diaria.

En la última parte del poema (estrofas 16 a 24), vemos como su apatía religiosa crece. Así, decide visitar otra Iglesia Carmelita porque está cansada de las mismas caras, de los mismos altares; después, hace sus compras y regresa a casa. Pensando en su muerte, se hace miembro de la Third Order $^{25}$, para que la alivie del dolor del Purgatorio; se imagina cómo irá vestida el día de su muerte — "Brown habit and white cord" (131), que es precisamente el hábito de los religiosos de esta orden; y pide un préstamo de noventa y cinco libras para reservar un pequeño espacio en el "terreno común" - "...for her bit / Of clay in the common plot" (134-135). Ingenua, completamente al margen de la realidad, imagina cómo será su retiro:

revealed.' ... The incident does not occur at Bethlehem, however, but in the temple at Jerusalem" (Maxton 237).

25 "The 'Third Order' or Tertiary was originally founded by St Francis of Assisi to provide a middle way between life in the world and life in the cloister" (Maxton 238). 
Often she thought of a quiet sick-ward,

Nuns, with delicious ways,

Consoling the miserable: quick

Tea, toast on trays. (136-139)

A partir de aquí, Clarke se centra en la sociedad e instituciones y las pasa por el tamiz de su sátira, un tamiz no tan fino como en las estrofas anteriores. Para empezar, los vecinos de Martha no la quieren alrededor: "Wishing to rid themselves of her, kind neighbours / Sent for the ambulance" (140-141), donde el irónico adjetivo "kind" no ensalza sino degrada. Cuando llega al hospital, la puerta de la entrada se cierra sonoramente, aislándola bruscamente del mundo exterior: "Big gate clanged" (143). Una vez dentro, sus ideales chocan de bruces con la amarga realidad de la vida irlandesa, a la que vivía prácticamente de espaldas. Martha Blake encuentra negligencia médica:

No medical examination

For the new patient. Doctor

Had gone to Cork on holidays. (144-146)

Padece insomnio. Poco a poco va tomando conciencia de su estado: experimenta un terror que le hace aferrarse a su rosario, como única salvación:

She could not sleep at night. Feeble

And old, two women raved

And cried to God. She held her beads

O how could she be saved? (152-155)

Advierte la falta de compasión por parte de las monjas que la atienden: 


\section{Mother superior believed}

That she was obstinate, self-willed

Sisters ignored her, hands-in-sleeves, (160-162)

Y no sólo siente que su estado de salud empeora por momentos, sino que su alma ya no está con ella. La cruda realidad de su cuerpo enfermo se impone sin contemplaciones: el cuerpo maltratado durante tantos años está tomando su revancha, ayudado, tristemente, por una institución que no muestra un mínimo de humanidad. Las palabras de Clarke describen una escena que no es solo patética sino terrible a inhumana:

They gave her purgatives.

Soul-less, she tottered to the toilet.

Only her body lived. (165-167)

Hemos destacado "soul-less" porque creemos que es una palabra clave en el poema y porque señala las intenciones satíricas de Clarke hacia la religión: una persona que ha estado toda su vida alimentando con toda dignidad su alma con la fe católica, se ve en los últimos momentos de su vida abandonada completamente por un alma desagradecida, metonimia implacable de la religión en que ella tanto creía. Quizás haya autores que consideren el ataque a las monjas como controversia, como veíamos en "Living on Sin". Sin embargo, no creemos que tengan que ser interpretadas como sinécdoque de toda la comunidad de monjas, sino como representantes puntuales de un hospital dirigido por unas instituciones que no destacan por su humanidad hacia los enfermos. 
Martha se ve abandonada por su alma, por las monjas del hospital, e, irónicamente, por su cuerpo, que rechaza la comunión: "Wasted by colitis, refused / The daily sacrament" (168-169). Y para completar el cuadro, el ataque de Clarke se refuerza con el parque de atracciones que las monjas habían dejado instalar en el campo de enfrente, que confiere un irónico matiz surrealista que despoja de cualquier atisbo de religiosidad y de humanidad a la escena. Martha se pregunta cómo podría rezar a Dios con tanto ruido. Su muerte sobreviene en términos de abandono total por parte de las instituciones. No recibe ayuda médica: se desangra a ritmo de jazz - "Bled inward to jazz" (188); e irónicamente, le es negado todo consuelo espiritual —“No priest / Came" (188-189). La última palabra del poema resume toda una vida de sacrificio espiritual que, en definitiva, no le ha servido para nada: 'disappointed'. Aquella alegre Martha, llena de gracia, de fe, de jovialidad del poema anterior muere en la más absoluta soledad, decepcionada, sin cuerpo y sin espíritu. El conflicto entre cuerpo y espíritu no lo ha ganado ninguno; más bien, lo han perdido los dos, y la contienda mantenida solo demuestra la futilidad del conflicto mismo.

Y decepción es probablemente la sensación que sentiría la protagonista de "The Vocation" (439), Angelica, al ser rechazada para la vida conventual:

Angelica was not robust

Enough to scrub the convent floors,

That ritual of humble pride. (16-18)

And still her visions were sweetly floral 
As she drifted towards the altar scent.

But in a year she was sent away. (121-123)

Este es otro poema más de desolación. En él, una mujer que sufre los prejuicios de la sociedad, se refugia en la religión, pero sus oraciones no logran reconciliarla ni con la primera ni con la segunda, ambas hostiles hacia Angelica. Clarke la observa:

Sometimes I see her in a car,

Ashamed to meet acquaintances,

Unhappy, her prayers of no avail,

Beyond the reach of her dear saints. (125-126)

Y decepción, de nuevo, es también lo que sentiría Miss Marnell, la protagonista del poema homónimo, "Miss Marnell" (210), otro ejemplo de pobreza y de parálisis existencial en el Dublín de Clarke, si llegara a recobrarse del colapso mental que sufrió. Las primeras líneas revelan el declive social de esta mujer y el grado de soledad en el que vivía:

No bells rang in her house. The silver plate

Was gone. She scarcely had a candle-wick,

Though old, to pray by, ne'er a maid to wait

At all. (1-4)

Convertida al catolicismo mucho tiempo atrás, Miss Marnell inspira la compasión de los narradores protestantes: “we pitied her, wondered about her past" (9). Llama la atención el detalle de que a pesar de haber sufrido un colapso mental, ella sigue firmemente aferrada a su rosario de cuentas marfileñas. Quizás en su limitada lucidez mental, el único resquicio que le queda está conquistado por la fe católica, 
lo que trae de nuevo a colación el gran poder de la religión católica, y la imposibilidad de deshacerse de ella. La religiosidad de Miss Marnell es intachable,

But her poor mind had not been organized;

She was taken away, fingering to the last

Her ivory decades. (10-12)

Su extremada pobreza contrasta con el dinero que da generosamente a la Iglesia:

Yet she had prospering money in the bank (15)

For convent, college, higher institutions

To build new churches or reduce their debt.

The figure on her cross-cheque made restitution

For many sins. Piled on her escritoire (22-25)

Circulars, leaflets, pleas that made her madder

To comfort those who need for holy living. (28-29)

Pero su obsesión por ayudar a la Iglesia es lo que al final la trastorna. Todo el poema es un retrato en el que se combinan y contrastan su pobreza y su soledad con las buenas obras que desea hacer. Según Harmon, "the figure on her crosscheque is her crucifixion. She dies to save the Church" ( $A C$ 148). Miss Marnell sólo es consciente de su "deber" como católica, sin preocuparse por ella misma, y, al igual que Martha Blake, vive obsesionada, olvidando completamente su vida terrenal. Su destrucción psíquica no le importa a nadie. Las cartas que se apilan en su buzón y que nadie lee son la última ironía de una vida paralizada por sus ideas 
religiosas: "In corners, faded notes of thanksgiving, / all signed - Yours gratefully, in Jesus Christ"” (31-32) ${ }^{26}$.

Los dañinos resultados del poder clerical que han desahuciado a las mujeres de los poemas anteriores aparecen representados en "The Loss of Strength" (212217) del poemario Too Great a Vine (1957). Dos significativas líneas del poema dan idea de una Iglesia que se ha hecho desmesuradamente poderosa:

Too great a vine, they say, can sour

The best of clay. (145-146)

En el Cristianismo, la viña es el símbolo de Cristo, pero si ésta crece excesivamente puede estropear el suelo en el que está plantada. Igualmente, "the Church by an excessive spread of influence has sapped the morale of the people" (Harmon, $A C$ 147). Los efectos de este poder incontrolado y emergen con singular destreza satírica en varios poemillas de Too Great a Vine, en los que se describen diferentes actividades humanas que Clarke usa para dirigir sus ataques contra la Iglesia.

En "Irish Mother" (217) vemos la lógica reacción moralista de una madre ante la sexualidad de su hijo:

'My son will burn in the Pit,'

She thought. Making his bed

And glancing under it:

'He slept last night,' she said.

\footnotetext{
36 "Yours gratefully, in Jesus Christ" es una forma convencional de despedirse en una carta propia del clero o de devotos católicos (Maxton 239.
} 
"Pit" es una referencia a "Hell". Como vimos más arriba, la madre era la que se ocupaba de mantener la moral católica en la casa, de ahí su preocupación por su hijo. En este caso, la madre sabe que su hijo sí ha dormido, porque de lo contrario hubiera supuesto que su hijo habría estado "perdiendo su alma" en actitudes quizás poco decorosas para la estricta moral católica.

"The Choice" (218) trata el problema del aborto y la religion. Veamos el poema:

\section{Better to disobey}

And keep her alive than pray

To scissors and rubber glove

So quickly again. Not love

But faith blesses our dust

In passing. Take cover: trust

\section{No fit of Caesar. Knife}

Killed him, brought to life.

Es mejor "desobedecer", es decir usar algún método anticonceptivo que tener que recurrir al aborto de nuevo. En este caso parece que ya ha habido un aborto: "So quickly again". La frase "Not love / But faith blesses our dust / In passing" es bastante compleja y difícil de explicar. Entre los significados de "dust" está el arcaico que se refiere a la mortalidad de nuestro cuerpo. Así, no es el amor lo que nos bendice al morir sino la fe católica, y si se practica un aborto la Iglesia no lo aprobaría. Por tanto, para evitar recurrir al aborto, Clarke recomienda usar algún anticonceptivo, en este caso un preservativo - "Take cover"-, y no fiarse de la 
historia de $\operatorname{Cesar}^{27}$, quien supuestamente nació mediante una cesárea (de aquí su nombre), puesto que un cuchillo lo trajo al mundo, pero otro lo apartó de él. Una cesárea no es lo mismo que un aborto, pero seguramente Clarke lo utilice de forma metonímica, es decir, adjudicando a "Caesar" y "abortion" una relación de contigüidad.

"Pilgrimage" (218) ridiculiza la explotación de los inválidos y ataca la creencia popular sobre Lourdes y los milagros, y contrasta el materialismo que rodea la parafernalia de Lourdes con la explotación de la agonía humana:

Too many thousands are brought to pray

Because our wonder must have crowds

Purchasing trifles at stall and tray

To make a holiday of hope,

Then, stare a stretcher, limbs that grope. (6-10)

La ironía es manifiesta en "must have crowds", porque cuanta más gente, mejor es el negocio de vender "trifles at stall and tray", y, sobre todo, en "To make a holiday of hope", lo cual degrada la esperanzadora intención de los peregrinos.

“Medical Missionary of Mary" (258), del poemario Flight to Africa (1963), critica igualmente los peregrinajes a Lourdes. En él se describe el accidente que sufre la hermana Michael al caerse de su bicicleta. La llevan a Lourdes en espera de un milagro y vuelve sin curar. Decide, por fin ir al médico, a la vista de los pobres resultados que ha obtenido con su rezos:

27 "No fit of Caesar". Un significado arcaico de "fit" es el de "song, ballad, story". 
Although she had made novena, kissed

The relics: worse than ever, came back

By London, lying on her back,

Saw there, thank Heaven, a specialist

And now is on the recovery list. (11-15)

Este es Clarke y su sátira más cruel. El irónico "thank Heaven” habla por sí solo.

Hay otros dos poemas en los que Clarke trata el mismo tema de las apariciones de la Virgen: "Orphide" (485-495) y "The Quarry" (496-490) ambos pertenecientes a Orphide and Other Poems (1970), y en los que no duda en criticar y satirizar el materialismo de la Iglesia Católica. "Orphide", un excelente y extenso poema, habla de Bernadette Soubirous ${ }^{28}$, santa francesa a quien se le apareció la Virgen, y de cómo fue tratada tanto por el Estado como por la propia Iglesia. En palabras de Harmon, este poema "shows how another human being, although granted miraculous contact with the divine, earns only suspicion, exploitation and deprivation" ( $A C$ 238). Además de ser un reconocimiento de Bernadette, el poema castiga a la Iglesia y a sus seguidores por haberla perseguido.

El poema está cronológicamente estructurado, como si se estuviese narrando oralmente. Las primeras estrofas establecen el escenario donde tienen lugar los acontecimientos - "Clouds held every pass of the Pyrenees / On that February

\footnotetext{
${ }^{28}$ Bernadette Soubirous (1844-79), santa francesa canonizada en 1933. A la edad de catorce años vio una serie de dieciocho apariciones de la Virgen en un periodo de seis meses. Debido a que se la consideraba mentalmente retrasada, el Estado y la Iglesia la interrogaron sobre sus visiones. Esto le dio una popularidad que hizo que entrara en la congregación Sisters of Notre-Dame en Nerves, donde cambió su nombre por el de Marie Thérèse Bernard. No participó en el subsiguiente desarrollo de Lourdes como centro de peregrinaje ni estuvo presente cuando se consagró la basílica en 1876. Murió a la temprana edad de 35 años, después de una larga enfermedad ( $c f$. Maxton 264).
} 
day" (1-2) - y presenta a Bernadette y sus amigas como "youngsters / In a folk tale" (29-30) recogiendo leña cerca de una cueva. Bernadette, la mayor de las tres, padece asma y no puede ayudar a sus amigas. Al quedar apartada del pequeño grupo, Bernadette experimenta la aparición de la Virgen:

...Standing there, all shining,

She saw a fair girl who robed in

White with s blue sash. Yellow roses

Half hid her bare toes, unwintered. (51-54)

Esta simple y casi ingenua visión de la niña, que ve a la Virgen como a un niña de su edad, no se cuestiona en ningún momento en el poema. Donde sí se ceba Clarke es en los que manipulan su historia con fines poco ortodoxos. Para empezar los sueños de su madre presagian el futuro de Lourdes,

...Enraptured,

She lay awake that night. Banners

Swayed with high blessings from the Cathedral

As thousands moved with Ave Marias

Towards the Grotto. She had conceived

And borne a saint for France. (90-96)

Sueños que, al mismo tiempo, contrastan con los de Bernadette, que sueña con seguir cuidando sus ovejas: "Bernadette dreamed she was minding her sheep: / A child again, proud of the shepherd's crook / Her uncle had shaped from ash" (102103).

Pero la dulce e inocente vida de Bernadette tiene los días contados porque inmediatamente su profesora empieza a reprenderla por contar mentiras: " 'Stand 
in the corner there till class / Is over,"' (157-158), con las consecuentes burlas de sus compañeros, provocadas no por el hecho de tener una compañera que ha visto a la Virgen, sino por el comportamiento de su profesora, Sister Philomena: "At recreation time the youngsters teased / The culprit, pulled her hair -all the week, / Nudged her, pinched her, pried" (161-163). El sacerdote local tampoco pierde la oportunidad de tomar parte y la interroga varias veces:

...Père

Peyramale sent in haste for hte bold one,

Questioned her severely. 'Now, tell me

Again.' 'A girl of my own age, robed

In white, with a blue sash, Father, a chaplet

And necklace of pure beads.' (173-178)

Pero a pesar de la cautela con que el sacerdote y la profesora tratan el caso de Bernadette, la histeria popular aumenta, y Lourdes cae bajo el hechizo de la aparición - “Lourdes was bespelled" (209), y los acontecimientos se desbordan. Ante esta situación, los poderes públicos se ven obligados a intervenir. Primero es la jerarquía eclesiástica:

The Bishop of Tarbes spoke from the pulpit:

'Heresy, superstition prevail

And must be stopped.' (237-239)

Después, el poder municipal:

... The Local Mayor,

In Council, ordered barricades 
To be set up around the Grotto

And muddy spring. (239-242)

Sin embargo, los disturbios aumentan porque la gente no acepta la violencia institucionalizada, y responde con ira destrozando las barricadas. Consecuentemente se envía al ejército para restablecer el orden: "Guarded / By upflash of sabre, carpenters / Restored the barricade" (252-254). Todos estos sucesos, a su vez, son recogidos por la prensa que los airea de tal forma que obligan al emperador Napoleón III a intervenir para que se retiren las barricadas. Lourdes se convierte en un gran centro de peregrinación; la vida de Bernadette, en cambio, queda relegada al sufrimiento: "In her dark room / Bernadette coughed, cried" (278-279).

Cuando ocurre el primer milagro, la jerarquía eclesiástica decide apartar a Bernadette de la escena y llevarla a un convento. En una excelente metáfora, Clarke utiliza una anécdota aparentemente insignificante en la que un sacerdote da un paseo por un jardín, y que le sirve para definir a la Iglesia como un poder cauteloso que absorbe la vida de todo lo que toca:

That evening, as he strolled by the potting-

Shed, glass-frames, beyond his rose-plots,

The Dean saw on the path a thrush drop,

Stubble, a snail-shell, tear

Life out... (294-298) 
Esta estupenda imagen indica lo que le ocurrirá a la humilde pastora. Su padre está entusiasmado con tanta celebridad. Le nombran director de un tostadero de maíz, y lo despiden por beber. No obstante acepta el futuro de su hija:

His child of fourteen was the future

Of Lourdes. To her new hospices

Convents, shops, cafés, banks, offices,

Hotels were all beholden. (321-324)

Clarke se pregunta:

... Could she endure

The glottal redness of the thurible,

The gasp-held tickle of that sweet-smother

Or guess that she was another

Captive of the Vatican? (311-315)

Este suceso sobrenatural es objeto de una vulgar explotación comercial de la que sacan beneficio todos menos la propia Bernadette, a quien han confinado en un convento contra su propia voluntad. Como dice Tappping,

Society and the Church alienate Bernadette from her rustic existence by forcing their ideals on her and subjecting her experience to the need for sensationalism and commercial exploitation. (AC 285).

Mientras la Iglesia y la sociedad celebran el éxito del suceso, la pobre pastora no tiene nada que celebrar. La ceremonia de toma de votos no significa nada para ella:

In a white wedding-dress, deeply veiled,

Bernadette stood before the altar

At last, betrothed without a dowry,

At twenty-three: no longer exalted 
In soul. Her parents waited, bowed

By tears. She heard, unhearing, the sound

Of Latin: Bride of Christ, unmoved,

Indifferent to her own good,

Those nuptials unavailing. (334.342)

Y para colmo de todos sus males, Bernadette, encerrada en una austera celda, se va derrumbando tanto física como psíquicamente. Los sueños bucólicos que endulzaban su vida se han convertido en pesadillas que agrian su existencia. Orphide - "a demon-goat"-, acosa su subconsciente con alucinaciones febriles _ “Feverish dreams gave her no rest” (361). Irónicamente Clarke comenta que el agua de Lourdes (famosa por sus propiedades curativas) no le produce ningún alivio, por lo que,

... By day, by night, shriek followed

Moan for the scarlet-black corolla

Of morphine, dismayed the Ursulines.

How could they know Orphide had sullied

All that she once beheld? (375-379)

Bernadette murió a los treinta y cinco años, completamente olvidada. Paradójicamente no hay estatua o iglesia que se erigiera en su memoria. La fuerza de la sátira de Clarke muestra la tensión entre el trágico destino de la pobre pastora y lo que Lourdes representa. Al igual que en "Martha Blake", "Miss Marnell" o en Mnemosyne, Clarke manifiesta su preocupación por las víctimas inocentes. En este relato de la pastorcilla, "Once again [Clarke] exposes the underside of the mind to show how even the innocent may be traumatised by evil" (AC 240). 
"The Quarry" está ligado al poema anterior por tres características: la escena tiene lugar en una paisaje natural, en este caso en el condado de Donegal en Irlanda, el objeto del poema es la Iglesia, y el hilo conductor es una visión de la Virgen. Pero a pesar de estas características, ambos poemas no tienen nada más en común: en el primero las visiones de Bernadette producen toda una revolución social y económica, independientemente de que las visiones de la niña sean verdad o no; en "The Quarry", en cambio, estamos ante una aparición falsa de la Virgen en una cantera de Donegal. El representante del Gobierno, su esposa y un paisano del pueblo se han asociado para estafar al pueblo. Así, el paisano cobra una entrada para acceder a la cantera, mientras que la esposa del representante, Mrs. Gallagher, posa como si fuera la Virgen, y su marido, Michael Gallagher, intenta conseguir el apoyo de la Iglesia a través del párroco Fr O’Donnell. Clarke juega con las dos acepciones de la palabra "quarry": cantera y presa; en este caso, la otra "quarry", es decir, "la presa", es el párroco, y si logran su apoyo, el engaño será total. Las palabras de Michael Gallagher son convincentes y tienen el aroma hipócrita que a menudo se identifica con el de la retórica de los políticos:

... 'Father I saw Our Lady

As clear as the new statue in

Our parish church, with shining halo,

Mantle of white and blue'. (49-52)

... 'They sent me

To ask you,' he added humbly, 'Whether

We're worthy of such grace?' (64-66) 
El párroco no acaba de convencerse y decide ir por sí mismo a la cantera y comprobar si la aparición es en realidad como le cuentan. Cuando llega allí, la atmósfera que se respira - “a solemn hush"- penetra en sus sentimientos con igual devoción. Sin embargo, al acercarse a la Virgen se da cuenta de que es la mujer de Mr. Gallagher:

... Gold of her Claddagh ring shone -

He recognised the wife

Of Deputy Gallagher. Smiling,

She lifted up her night-dress. (97-100)

Todo se había apañado para sacar dinero de la gente pobre e incrédula del pueblo. El poema ridiculiza a la Iglesia porque ésta aparece como un objeto a merced de algunos grupos políticos. Si extrapolamos el engaño, llegaríamos a la alianza tácita del Gobierno de Irlanda con la Iglesia Católica que ha dominado buena parte de la historia de la Irlanda contemporánea.

Siguiendo con poemas que tienen a la Iglesia como protagonista, encontramos "St. Christopher" (219), otro pequeño poema de Too Great a Vine que contiene una fábula y una pregunta. La fábula habla de un joven al que compara con los tocones de los ríos y que, al convertirse en gigante, destroza la orilla del río donde se asentaba. La alegoría sirve para criticar el mismo crecimiento desmesurado de la Iglesia:

Fabulists, can an ill state

Like ours, carry so great

A Church upon its back? 
Clarke ataca sistemáticamente la rapacidad económica-de la Iglesia. "Offerings" (198), poema de Ancient Lights (1955), deja al descubierto la avaricia eclesiástica al oponer la relación que existe entre el dinero que dejan las personas para misas con su recuerdo después de muertas. Las almas que penan en el purgatorio proveen el punto de vista del poema:

...Soon, very soon, we fade

As memory when our small savings

Are gone and every Mass is said. (5-7)

El tono satírico se consigue a través de la reducción al absurdo: la ficción satírica consiste en el monólogo de las propias almas muertas quejándose de que sólo se las recuerda mientras dura el dinero que dejaron. Al acabarse éste, se acabó también su recuerdo.

"Bequests" (198), compañero de poemario del anterior, ataca igualmente la avaricia de las instituciones religiosas. Las "campanas" religiosas están dispuestas a hacer lo que sea hasta que se haya recaudado la contribución necesaria; las manos eclesiásticas siempre están abiertas para agarrar el dinero del que se muere:

When money burns in the last breath

Of frightened age, such bells are set

In air, their tongues will stick at nothing

Until religious institutions

Have storied every contribution. (1-5)

La liberación de los dogmas religiosos es otro de los temas que toca Clarke en sus poemas satíricos. En "An Early Start" (203), la situación en la que se 
encuentra el protagonista del poema roza la comicidad: está adormecido y le despiertan las campanas de la iglesia. Se pregunta si los religiosos han comprado una campana más grande. En vano se tapa las orejas con las manos y se niega a levantarse. Las campanas simbolizan las ataduras religiosas del dogma católico, que la Iglesia intenta afianzar de forma económica. La sátira, aunque muy suave, se encuentra en las líneas,

\section{...guessing}

The Fathers of the Holy Ghost had bought

A bigger bell. Why should our blessed truth

Be measured by the mile? (2-5)

En las que pregunta a la Iglesia si la fe se puede medir por la cantidad de riquezas materiales. El narrador es firme en su decisión de ignorar las campanadas: "I will lie on / Refuse to count a stroke" (7-8).

"On the Mountain Tops" (287), de Flight to Africa (1963), sigue en la misma línea, atacando el gasto innecesario de la Iglesia que se preocupa más por su imagen y apariencia que por las reales necesidades humanas. El poema se centra en la construcción de numerosos monumentos religiosos por todo el país. Las primeras líneas muestran un pueblo medio desierto donde la gente vive en extrema pobreza:

Religion, shrining the country town,

The monthly fair, can now look down

On German settlers, half-empty village. (1-3)

The Clergy bless another show 
Of faith. On rock and mountain top,

Far South or West, contractors are popping

An iron cross in concrete ...

White dot in the Gap of Tipperary, Look, statue to the Virgin Mary. (15-16)

$\mathrm{El}$ ataque de Clarke no incluye exclusivamente el mero hecho de levantar estatuas sino la poca preocupación que pone la Iglesia por la vida humana, con lo que cuestiona los pilares morales de esta Institución: el compromiso con su responsabilidad social se lleva a cabo solo cuando le conviene. En palabras de Garrat,

The "show of faith" is just that -appearance- and it takes precedence over genuine human charity. Thus, in a kind of Swiftian reversal, Clarke attacks the Church for its insistence on the appearance rather than the practice of piety and charity. ...the clergy propose only those solutions to problems that do not endanger their position in Irish society. (“Aware" 98)

Otro buen ejemplo es "Local Complainer" (211), de Too Great a Vine, en el que sigue ridiculizando el celo con que la Iglesia construye estatuas ${ }^{29}$. El poema está narrado desde el punto de vista de un protestante, y contrapone irónicamente la piedad pública al declive económico. Las estatuas se levantan con tanto fervor que ni los protestantes "call it a sin"; es más, están dispuestos a pagar a pesar de

\footnotetext{
${ }^{9}$ Clarke en sus notas a Colected Poems (1974) afirma: "As the result of wide organization, religious statues have been erected in many towns and villages, by the roadside, on hilltops, outside factories, quarries and mines, and in the poorer districts of Dublin. Most of these are painted plaster casts, supplied by enterprising firms. They may prove our public piety, but certainly display our total lack of artistic taste" (550).
} 
que les está prohibida la adoración de estatuas: “...Our chequebooks / are opened gladly for their statue, / Despite the Decalogue" (18-20). Las primeras líneas apuntan al desequilibrio entre piedad y economía:

Their new Madonna at the quay-side,

Without a vessel in the tide-way, (1-2)

Satírica es también la descripción de la inauguración de la estatua, en la que contrasta la fastuosidad de los asistentes con la pobreza que se pasea por las calles de Dublín:

The clergy came, the Mayor with gownsmen,

Past derelicts of mill and warehouse

That bulge with emptiness. (7-9)

Clarke, en su continua actitud crítica contra la Iglesia, no se olvida de sus obispos. En "Irish-American Dignitary" (221), nos presenta una escena en la que el obispo de Boston, Dr Cushing, visita fugazmente Irlanda en busca de sus orígenes, 'To find his father's cot', y sin tiempo apenas para comer:

...so many kissing

His ring - God love him! - almost missed

The waiting liner: that day in Cork

Had scarcely time for knife and fork. (9-12)

El poema es un ataque suave, más bien irónico, en el que más que una sátira es una burla irónica del obispo. No tendrá, sin embargo, tanta suerte el obispo de Killmore, protagonista sin escrúpulos de la agresiva sátira que nos ofrece Clarke en “Three Poems About Children" (196-97). 
El poema relata la muerte de un grupo de niños 'que quedaron atrapados en un dormitorio de un orfanato de County Cavan cuando éste se incendió. Clarke escribió el poema como respuesta al comentario que hizo el obispo de Killmore, Dr. Lyons, al referirse a las jóvenes víctimas: "Dear little angels, now before God in Heaven, they were taken away before the gold of their innocence had been tarnished by the soil of the world" ${ }^{\prime 30}$ (Harmon, $A C$ 145). Además de una respuesta contundente al poco acertado comentario del obispo, el poema es también un rechazo absoluto hacia la poca preocupación de la Iglesia Católica por el ser humano, especialmente cuando se trata de mujeres o, como en este caso, de niños.

"Three Poems About Children", como el título expresa, está compuesto de tres pequeños poemas. En el primero, empieza Clarke comparando la época de las Leyes Penales - "Penal Age"- con los tiempos modernos, y concluye que es preferible estar proscrito - 'roofless faith' - que soportar el catolicismo moderno que "oppresses by devaluing man and his earthly life in favor of eternal salvation -a faith that mocks time by eternalising mute souls" (Schirmer, PAC 82):

Better the book against the rock ${ }^{31}$,

The misery of roofless faith,

Than all this mockery of time,

Eternalising of mute souls.

\footnotetext{
${ }^{30}$ Esta noticia apareció en el Irish Times del 26 de Febrero de 1943. El orfanato en cuestión era el de St Joseph, situado en Main Street, en la ciudad de Cavan. El fuego ocurrió la noche del 23 al 24 de febrero de 1943. Murieron 35 niños y un adulto, una mujer mayor llamada Maggie Smith. El gobierno irlandés, a cuyo cargo estaba el novelista Flann O'Brian, creó un Tribunal para resolver el caso, pero no se pudo establecer sobre quién recaía la responsabilidad (Maxton 228).

${ }^{31}$ The book against the rock' recuerda el periodo cuando la adoración católica ('a roofless faith') se celebraba al aire libre y en lugares remotos (algunos conocidos como "mass rocks") (Maxton 228).
} 
Though offerings increase, increase,

The ancient arms can bring no peace,

When the first breath is unforgiven

And charity to find a home,

Redeems the baby from the breast.

$\mathrm{O}$, then, at the very font of grace,

Pity, pity - the dumb must cry.

Their tiny tears are in the walls

We build. They turn to dust so soon,

How can we learn upon our knees,

That ironside ${ }^{32}$ unropes de bell? (I. 1-15)

El poema expone la idea de que la Iglesia solo parece crecer en términos materiales pero no humanos. La línea "When the first breath is unforgiven" puede referirse a las criaturas que la Iglesia considera ilegítimas y que la "caridad" irónicamente redime al apartarlas del legítimo pecho materno y llevarlas a los orfanatos del Estado. Pero, según Schirmer, ese verso también se refiere a la doctrina del pecado original, "which Clarke sees lying at the heart of the Catholic Church's antihumanistic teachings since it sees man as fallen from the moment of birth" (PAC 82). De igual modo, las líneas "Their tiny tears are in the walls / We build" pueden encerrar dos interpretaciones diferentes. La primera es básicamente literal, y pone sobre la mesa la dignidad de los orfanatos que se construyen para criaturas ilegítimas; la segunda hace referencia al sufrimiento que causan las actitudes

\footnotetext{
32 'Ironside', según Maxton (228), invoca a Oliver Cromwell, que se dedicó a silenciar y proscribir el culto católico. También el término llegó a ser sinónimo de crueldad en Irlanda, ya que las tropas de caballería de Cromwell se conocían como "ironsides".
} 
inhumanas de la Iglesia, que paradójicamente encierrah en su seno. Las últimas líneas muestran la crueldad de la Iglesia al comparar su falta de humanidad a la hora de llorar la pérdida de las pobres criaturas con la crueldad con que trató Cromwell a los católicos en el siglo XVII; así, igual que la crueldad de Cromwell “descolgaba campanas”, las intransigentes opiniones de la Iglesia Católica privan a los niños ilegítimos de su derecho a que las campanas doblen también por ellos.

El segundo poema continúa atacando a la doctrina de la Iglesia en cuanto a los niños huérfanos que mueren sin bautizar. El poema argumenta que las criaturas que van al limbo después de morir no se salvan, pero tampoco se les concede el beneficio del amor humano. Es decir, en el verso de Clarke, y según el atroz razonamiento del obispo, las criaturas quedan "Unfathered in our thought" (II. 4), apartadas de la respuesta natural del ser humano por sus muertos. La fe permite "Obscurity of being / and clay rejoice" (referencia a la salvación eterna), pero en este caso, las criaturas - “flowers" en el poema - no habían recibido la bendición del Sagrado Sacramento, por lo que sus vidas son cruelmente arrojadas a la basura. Parece que el sacramento del bautismo es razón sine qua non para que una pobre criatura sea considerada digna de obtener los beneficios de la religión católica. En caso contrario, argumenta Clarke, la Iglesia simplemente se lava las manos en el asunto:

Though faith allow

Obscurity of being

And clay rejoice: flowers

That wither in the heat 
Of benediction, one

By one, are thrown away. (II. 6-11)

En el tercer poema Clarke libera su ira contra la Iglesia y su representante. Comienza con una sistemática negación de confianza en la fe, ya que tanto mártires como herejes han ardido en la hoguera: "Martyr and heretic / Have been the shrieking wick!" (III. 1-2). Las siguientes líneas parecen sugerir cínicamente que la frase que dijo el obispo era en realidad una forma de eludir responsabilidades por parte de la Iglesia:

But smoke of faith on fire

Can hide us from enquiry

And trust in Providence

Rid us of vain expense. (III. 3-6)

Clarke pregunta si deberíamos dejar que la "piedad' exponga lo que ocurrió en el fuego,

So why should pity uncage

A burning orphanage,

Bar flight to little souls

That set no churchbell tolling? (III. 7-10)

Es decir, ¿por qué deberíamos poner en duda la noción reconfortante de la transformación de los niños en ángeles? Al hacer que no doblen las campanas por ellos, se evita la aflicción que su muerte produce.

La segunda estrofa de este tercer poema resalta la inhumana crueldad del argumento del obispo: 
Cast-iron step and rail

Could but prolong the wailing:

Has not a Bishop declared

That flame-wrapped babes are spared

Our life-time of temptation? (III. 11-15)

Si hubiera habido una escalera de incendio, los niños se habrían salvado, pero habrían sufrido más al tener que vivir en un mundo corrupto y pecaminoso. El poema termina con dos líneas que resumen el argumento casuístico del Obispo, que aplica los principios morales de la Iglesia a un caso que tiene que ver más con acciones humanas que con posturas teológicas:

Those children, charred in Cavan,

Passed straight through Hell to Heaven. (III. 19-20)

"Three Poems About Children" ofrece más que una mordaz respuesta a las afirmaciones del Obispo: es una dura exposición de la falta de humanidad de la Iglesia de la época. En palabras de Schirmer, "it challenges the philosophy that lies behind that statement, and argues for the worth of human experience and human dignity" (PAC 85). 


\section{3 A. Clarke y las Instituciones: La Iglesia Católica y el Estado.}

Como hemos visto a lo largo de este capítulo, la Iglesia y el Estado se mantuvieron suficientemente cerca el uno del otro en la construcción del Estado Libre y de la futura república irlandesa. Clarke nunca vio con buenos ojos la alianza de estos dos poderes, y no dudó en manifestar mediante sátiras el descontento que le producía el control que estas dos instituciones mantendrían sobre la conciencia del pueblo irlandés hasta bien entrados los años setenta. Este estricto control crearía un conflicto entre la innata libertad del ser humano y el control al que ésta era sometida. En este apartado, veremos las sátiras que escribió contra la citada alianza.

Comencemos con el poema que abre Ancient Lights de 1955: "Celebrations" (195). El poema había aparecido publicado con anterioridad en 1941, en el volumen de enero de la revista Dublin Magazine. El título del poema ha mantenido ocupados a críticos literarios y estudiosos, que han intentado averiguar a qué celebraciones se refería el título. Garrat mantiene que se refiere al Congreso Eucarístico en Dublín de 1932, "where church and state celebrate their 'Prosperity' in Ireland" ( $A C$ 115). Harmon está de acuerdo pero ofrece como alternativa el 25 Aniversario de la Insurrección de Pascua de $1916^{33}$ ("Later" 50). Además, como apunta Cooney, el tema central del poema seguía teniendo validez en las puertas del 50 Aniversario de dicha Insurrección:

\footnotetext{
${ }^{33}$ Clarke en sus notas a $C P(1974)$ acepta las dos interpretaciones. El título, además, no habla de una sola celebración sino de varias, al estar en plural (548).
} 
Prosperity complacently celebrated in a country politically and religiously divided and dominated in the South by the Church is in ironic contrast with - if not a mockery of - the dreams and ideals of the Republic's founders, the men of Easter week. ("Commentary" 18)

El poema es un buen ejemplo de la dificultad que encierran algunos de los versos de Clarke. Para lectores que no estén familiarizados con la historia de Irlanda, el poema resulta completamente opaco, por lo que la información previa del lector es imprescindible para poder extraer la mayor cantidad de significado posible. "Celebrations" enfrenta satíricamente los ideales y valores del pasado con los del presente. Todo el poema está construido en función de los significados del léxico, por lo que varias interpretaciones pueden extraerse de su lectura. Como hemos dicho, toda sátira implica un ataque que se realiza a través de un artificio retórico, y que revela al lector una verdad, llamada verdad satírica. En este caso, el ataque se cierne sobre la alianza Iglesia-Estado, que celebra su prosperidad; la verdad satírica consiste en mostrar al lector lo que Clarke considera como una teocracia corrupta y egoísta. En palabras de Cooney, la verdadera intención del poema es la de "expose the faults and corruptions of Irish society and to invoke and assert the values by which this society must be judged" (19).

Who dare complain or be ashamed

Of liberties our arms have taken?

For every spike upon that gateway,

We have uncrowned the past:

And open hearts are celebrating 
Prosperity of church and state

In the shade of Dublin Castle. (1-7)

Las dos primeras líneas ${ }^{34}$ parecen querer confundir al lector y marcan el tono del resto del poema. Así, "Taken" puede significar "taken away" o "won", y "liberties our arms have taken" implica que alguien se ha tomado libertades (por ejemplo con Irlanda, personificada normalmente como una mujer) o libertades que se han obtenido. Las dos líneas siguientes juegan con el significado de "spikes" y "uncrowned". "Spikes" puede ser una alusión a la costumbre de empalar las cabezas de los rebeldes en las puntas de las verjas que daban paso a Dublin Castle $^{35}$, o puede también aludir a las cabezas de los irlandeses republicanos ejecutados por los gobiernos posteriores al Tratado ${ }^{36}$. "Uncrowned", por otro lado, puede referirse a la emancipación de Irlanda de la corona Británica, o al hecho de que los irlandeses han perdido algo digno de ser coronado: "a past in which the true spirit of nationalism flourished" (Schirmer PAC 69). Las tres últimas líneas de la estrofa son más irónicas y enfatizan que lo que se está celebrando es la prosperidad material de la Iglesia y el Estado en vez de celebrar la libertad. "Shade" puede significar que Dublin Castle ya no es un símbolo de dominio

\footnotetext{
${ }^{34}$ Harmon $(A C$ 140) comenta que estas dos primeras líneas evocan dos baladas patrióticas: "Who Fears to Speak of Ninety-Eight", en referencia a la Insurrección de 1798, y "Who Fears to speak of Easter Week" en referencia al Levantamiento de Pascua de 1916.

35 "Castillo de Dublín que mandó construir el rey anglonormando Juan (1167-1216).... Fue la sede oficial del virrey de Irlanda (Lord-Lieutenant) y, en consecuencia, el centro administrativo del gobierno británico en la isla desde 1565 hasta la creación del Estado Libre de Irlanda (Free State) en 1922" (Hurtley et al 87).

${ }^{36}$ En las notas a $C P(1974)$, Clarke enumera las víctimas de los gobiernos republicanos: “....seventy Republicans were executed by the Provisional Government. Between 1936-46, when the Republican Government was in power, of the small group of political intransigents four were shot without trial, four were shot by firing squad, one was hanged by Pierpoint, and three died on hunger strike" (548).
} 
extranjero, pero también tiene el significado de "espéctro", que sugiere que el control extranjero se ha sustituido por una nueva clase de opresión (Harmon, “Later” 51).

So many flagpoles can be seen now

Freeing the crowd, while crisscross keys,

On yellow-and-white above the green,

Treble the wards of nation,

God only knows what treasury

Uncrams to keep each city borough

And thoroughfare in grace. (8-14)

Esta segunda estrofa comienza ironizando sobre la libertad que han conseguido los irlandeses por medio de distintos "mástiles de banderas" _ “flagpoles"-, metonimias respectivas de la Iglesia, representada por la bandera papal - "crisscross keys, / On yellow-and-white"; de los británicos, simbolizada por "above the green", que es una alusión a Trinity College; y del gobierno de Irlanda. La palabra "wards" administrativas, salas de hospital, tutelaje, clavija de una cerradura - todos ellos dentro de un mismo campo semántico: control. Éste contrasta irónicamente con la idea de libertad, que se halla tanto en la primera como en la segunda estrofa. Para redondear el ataque, Clarke juega en las tres últimas líneas con la oposición materialismo y espiritualidad en las palabras "treasury" y "grace", lo que refuerza

\footnotetext{
${ }^{37}$ Cf. Cooney, Seamus. “Austin Clarke's 'Celebration': A Commentary”. En este excelente artículo, el autor comenta todos y cada uno de los varios significados de "treble" y "wards". Para nuestro estudio son irrelevantes porque no nos apartan de la idea central de Clarke: la de satirizar el tándem Iglesia-Estado y la falta de libertad de Irlanda.
} 
la dependencia materialista de la Iglesia del erario público para mantener la ciudad "en gracia".

Let ageing politicians pray

Again, hoardings recount our faith,

The blindfold woman in a rage

Condemn her own for treason:

No steeple topped the scale that Monday,

Rebel souls had lost their savings

And looters braved the street. (15-21)

La última estrofa continúa en la misma línea que las anteriores, y lanza una invectiva contra el materialismo y la falta de libertad de la Irlanda moderna. La estrofa está formada por tres oraciones concesivas, las tres modificadas por "Let". Así, la primera oración, "Let ageing politicians pray", denuncia la unión de los políticos con la Iglesia, a la vez que hace referencia a aquellos que participaron en la Insurrección de Pascua, políticos que están ya envejeciendo y que una vez "rezaron" por conseguir la libertad y ahora "rezan" quizás porque ven el final de sus días o quizás por sus propias convicciones religiosas. En cualquier caso, el tono irónico de Clarke sugiere su sumisión a la Iglesia. La siguiente oración concesiva, "[Let] hoardings recount our faith" muestra que la nueva fe está ahora centrada en el dinero y no en la religión. Y, por último en "[Let] the blindfold woman ... condemn her own for treason" la mujer vendada puede ser la Justicia o Irlanda. En el primer caso se refiere a la estatua que se encuentra colocada encima de la puerta de Dublin Castle. En el pasado, era la Justicia Británica la que 
condenaba a los rebeldes irlandeses por traición; ahora,' en cambio, es la Justicia irlandesa la que, enfurecida, condena a su propia gente por haber traicionado los ideales de aquellos que ayudaron a reemplazar el dominio británico por el irlandés.

El presente de Irlanda de las tres oraciones concesivas lo enfrenta Clarke a su pasado heroico en las tres últimas líneas del poema. La corrupción del presente contrasta de lleno con la Insurrección de Pascua de 1916, cuando los rebeldes perdieron todo lo que tenían - tanto material como espiritual. El ataque de Clarke se centra en el hecho de que la Iglesia no inclinó los platillos de la balanza de la Justicia a favor de los rebeldes — "No steeple topped the scale that Monday"38 - ni tampoco lo hace en la actualidad. La última línea se refiere tanto a los saqueadores que se aprovecharon de la confusión para saquear la ciudad y que, como dice Cooney, "were the true harbingers of the money-grubbing half-nation which Clarke so bitterly derides and which is now so smugly celebrating its own prosperity" (24), como a los funcionarios de la Iglesia y del Estado de la Irlanda del Congreso Eucarístico.

El artificio satírico es la comparación irónica de las dos Irlandas, la de la Insurrección de Pascua de 1916 y la del Congreso Eucarístico de 1932. Aunque Clarke satiriza la alianza Iglesia-Estado, el sentimiento que emerge del poema es el del fracaso del esfuerzo de los poderes irlandeses en reconciliar pasado con presente. Lyons asegura que nadie que estudie la historia de los últimos cuarenta

\footnotetext{
${ }^{38}$ Según Cooney, " 'topped' forms what Clarke calls a 'mind-rhyme' with 'tipped' - to tip the scales of British justice in their favor when the captured rebels were courtmartialled and shot" (24).
} 
años en Irlanda, ni quien lea lo que los escritores irlandeses han escrito sobre las condiciones de su país, ni nadie que observe su evolución puede evitar darse cuenta del trasfondo de frustración y cinismo que ha pugnado por colocarse en el primer plano de la esfera política y social (683). Y, precisamente, es este sentimiento de traición hacia los ideales de la rebelión de 1916 lo que aflora en el poema de Clarke, que lo expresa atacando tanto al Estado y a la Iglesia como a la coalición de ambas.

"Mother and Child" (202) se centra en el suceso que "most clearly demonstrated ecclesiastical interference in politics" (Harmon, $A C$ 141). En los años -50, la influencia de la Iglesia en el Gobierno rozaba el totalitarismo: "The highly politicized nature of Church authority, in an almost uniformly Catholic state, acted as a powerful cementing factor in the Republic" (Foster, Modern 571). El poema ironiza sobre la derrota de la propuesta del gobierno de ofrecer servicio médico gratuito a todas las madres durante y después del embarazo, así como a los hijos hasta los dieciséis años. La controversia ${ }^{39}$ surgió por parte de la Iglesia, que no estaba dispuesta a aceptar que se aprobase una ley que no discriminara entre nacimientos legítimos e ilegítimos. Consecuentemente, los obispos denunciaron la normativa sobre la asistencia medica como "a ready-made instrument for future

\footnotetext{
${ }^{39}$ En realidad, el Plan Nacional de Apoyo a la Maternidad fue "rechazado de pleno por la mayoría de los médicos del país, que alegaban que no estaba previsto ningún mecanismo para investigar los ingresos de los solicitantes para determinar si tenían derecho o no a las diferentes prestaciones. Los médicos contaron con el apoyo de la Iglesia Católica, que consideraba que infringía el derecho de la persona a elegir su médico sin intervención estatal. Pero en el fondo, la jerarquía católica estaba preocupada por cuestiones de orden moral" (Hurtley et al 213).
} 
totalitarian aggression ... we have no guarantee that state officials will respect Catholic principles in regard to these matter" (Foster, Modern 572). Esto obligó a que el concepto universal de seguridad social de Noel Browne, a la sazón ministro de Sanidad y responsable de la controversia, tuviera que esperar. Clarke aprovechó la conmemoración del Año Mariano de 1953-54 para expresar su disgusto por la hipócrita contradicción en que incurría la Iglesia al dar más prioridad a una celebración, que precisamente usaba como símbolo a una madre y un niño, que a las madres y los hijos que forman su iglesia. "Mother and Child" ridiculiza la hipocresía de la Iglesia y el servilismo del Estado hacia ella. El título se refiere a un sello de correos en el que aparecen la Virgen y el Niño Jesús.

Obedient keys rattled in locks,

Bottles in old dispensaries

Were shaken and the ballot boxes

Hid politicians on their knees

When pity showed us what we are.

'Why should we care,' votes cried, 'for child

Or mother? Common help is harmful

And state-control must starve the soul.'

One doctor spoke out. Bishops mitred. (1-9)

Dos imágenes aparecen en la estrofa. Una, la de los políticos escondiéndose detrás de las urnas rezando y temerosos de la Iglesia, y la otra, la de los médicos que protestaron enérgicamente para impedir que se aprobara el Plan Nacional de Apoyo a la Maternidad. Esta irrisoria imagen no sólo ridiculiza al gobierno en el poder, sino que da una visión del efecto de la influencia de la Iglesia Católica en la 
Irlanda moderna. La cobarde acción de esconderse es lo que la "piedad" les obliga a hacer. A la Iglesia, al contrario, no le reserva imágenes degradantes sino invectiva irónica: 'Why should we care ...for child / Or mother?' es una llana pero directa alusión a la ausencia de humanidad de la Iglesia, que en su defensa alega que el control estatal 'starve the soul', es decir, destruye la santidad familiar. La última línea del fragmento muestra la preocupación del doctor Noel Browne por esas madres que seguramente no podían costearse los gatos de un médico privado - de ahí que éstos protestaran tan enérgicamente-, y la despreocupación de los obispos que simplemente se pusieron sus mitras, sin pensar que su obligación debería ser la de interesarse más por el ser humano como tal, independientemente de sexo, raza o religión.

El poema termina con una degradante alusión a la relación entre madre e hijo en el sello de correos que conmemora la ocasión:

Before you damp it with your spit, Respect our newest postage stamp. (14-15)

Es decir, antes de usar el sello, respeta lo que en él aparece. Para Tapping, el sentido blasfemo que encierran estas líneas al sugerir la ilegitimidad de Cristo, está totalmente intencionado (179).

Y estos políticos postrados de rodillas ante una Iglesia intransigente son los mismos que acudieron al entierro de Douglas $\mathrm{Hyde}^{40}$, y que dieron ocasión para

t0 Douglas Hyde, 1860-1949, fue "escritor, traductor, ideólogo nacionalista y político; primer Presidente de Irlanda" (cf. Hurtley et al 149). 
que Clarke los ridiculizara con otro poema satírico, "Burial of an Irish President" (250). Clarke describe dos escenas contrapuestas, la que tiene lugar dentro de la Catedral de St. Patrick, la iglesia protestante en la que se oficiaba el funeral del presidente, y la que muestra lo que sucedía afuera. Como Hyde era protestante, los católicos asistentes a las exequias, con excepción de Clarke y el embajador francés, se quedaron fuera de la Iglesia. Según Harmon, en los días anteriores al Concilio Vaticano II, los católicos estaban obligados a pedir permiso a sus sacerdotes si deseaban asistir a un servicio religioso protestante (AC 192).

El artificio satírico que emplea Clarke es la comparación de las dos escenas: la solemnidad que representa el funeral de un presidente está en franca oposición al deshonor que muestra el grupo de representantes del gobierno cuyos prejuicios religiosos les impide asistir en cuerpo y alma al funeral. La escena que protagonizan es absolutamente ridícula:

... Outside

The hush of Dublin town,

Professors of cap and gown,

Costello, his Cabinet,

In Government cars, hiding

Around the corner, ready

Tall hat in hand, dreading

Our Father in English. Better

Not hear that 'which' for 'who'

And risk eternal doom. (23-32 
Quizás sea ésta una de las pocas sátiras de Clarke que sí provocan la risa del lector, especialmente al contemplar al grupo de políticos escondidos fuera de la Iglesia - 'hiding / Around the corner' - sin atreverse a entrar en la catedral. Pero, a su vez, también es un poema que produce pena, al menos en el lector contemporáneo, al comprobar cómo los prejuicios religiosos evitan que alguien que ha contribuido a mejorar su país sea honrado como se merece por los representantes de su país. Es una muestra más de la dependencia servil del Estado de la Iglesia, y, al mismo tiempo, del fanatismo religioso de la Iglesia Católica en Irlanda. Aparte de poner en evidencia a los asistentes católicos, el verdadero objetivo del poema es mostrar la intolerancia de las instituciones a la hora de estar a la altura de lo que las circunstancias les exigen.

El hecho de adolecer de prejuicios religiosos no es solamente propio de los políticos: los defectos y virtudes de la religión penetran en todas y cada una de las capas de la sociedad. Clarke lo sabe y lo muestra en varios poemas. En "Street Game" (256) rememora un incidente que observó mientras paseaba por Dublín. Superficialmente nos muestra a un grupo harapiento de muchachos católicos, herederos también de los mismos prejuicios religiosos que los políticos de los poemas anteriores, insultando a un grupo de niños huérfanos protestantes que van acompañados de su profesor religioso:

...Suddenly Catholic joylets

Darted from alleys, raggedy cherubs that dared them:

'Luk, feckin' bastards, swaddleers, feckin' bastards!'

Too well they knew the words their mothers, fathers, 
Used. (11-15)

Pero el poema no se limita solamente a mostrarle al lector el mero prejuicio religioso. Para empezar, el contraste entre la pobreza del barrio de Coombe donde viven los niños católicos - "raggedy cherubs"-, y la buena apariencia de los protestantes - "well-fed pairs"- es patente. Contribuye asimismo a esta oposición el sonido que los niños protestantes van haciendo con sus zapatos - "boot-heel metal"-, que evoca la vieja opresión protestante. En palabras de Schirmer, el poema "moves beyond a simple condemnation of religious bigotry among Irish Catholics to a much broader statement about religious and political discrimination in general" (PAC 76). La religión no solamente reprime sino divide socialmente a la sociedad. En la historia de Irlanda, el simple hecho de pertenecer a uno u otro credo del Cristianismo ha sido origen de odios y disputas que, como muestra el poema, parecían estar enraizadas en los genes del pueblo irlandés ${ }^{41}$. Las últimas líneas, "Devotion, come to the man-hole at last, / Bawls: 'Feckin' bastards, swaddlers, feckin' bastards!" (17-18), degradan el significado de la palabra "devotion" y todo lo que connota al situarla en un agujero de alcantarilla y al obligarla a bramar una serie de insultos contrarios totalmente al verdadero espíritu de la religión, sea ésta del credo que sea.

Este peculiar y, sobre todo, paradójico poder de la religión como divisoria social aparece también reflejado en "The Wounds of Fodhla" (251), poema que

\footnotetext{
${ }^{41}$ En la República de Irlanda actual, el odio ancestral entre católicos y protestantes no es ni la sombra de lo que fue en la época de Clarke, ni que decir antes. Pero una buena muestra de la intensidad del conflicto sigue existiendo en Irlanda del Norte.
} 
describe cómo una multitud campesina apalea a un evangelista protestante y cómo éste es después juzgado por un tribunal rural.

\section{Evangelist,}

Headlong, upset by farm-boot, fist,

Two teeth knocked out, a bit o' twist,

Bible kicked in the gutter but kissed

Next morning. Bench did not insist

Too much on detail:

\section{'Case dismissed.' (3-9)}

Clarke expone y ridiculiza la brutalidad de unos ciudadanos católicos que se supone deberían comportarse de acuerdo con unas elementales normas de civismo. El poema recuerda el retrato que de los "Yahoo" hacía Swift en Gulliver's Travels, en el que también se ofrece "a side of man both offensive and shocking" ("Aware" 102). Clarke, tanto en este poema como en el anterior, degrada la conducta del ser humano, exponiendo sus defectos y sus vicios, que en este caso viene regida por sus prejuicios religiosos.

Entre los numerosos defectos de que puede adolecer una sociedad, resalta su habilidad para albergar injusticias sociales, las cuales se cometen a menudo con la muda aquiescencia de las instituciones en el poder. Clarke escribió varios poemas en los que denuncia las grandes diferencias sociales que existían en la Irlanda de su tiempo. Empecemos con "A Simple Tale" (257), en el que Pat Rourke, un trabajador temporal, vuelve a Irlanda con su mujer y sus hijos y no puede encontrar 
trabajo. Las circunstancias le obligan a vivir en la miseria, y ésta le lleva a delinquir para poder alimentar a su familia. La escena habla por sí sola,

All slept in a coal-hole, heard (4)

The gulls, loop-lining near Dublin Bay,

Squabble for offal, rub of cur

Or cat around a dustbin, till

A-bang in breadshop, dairy. (7-10)

Clarke ataca a un gobierno que prefiere separar a una familia en vez de ayudarla y mantenerla unida porque su sistema social no puede dar trabajo a sus desempleados. El padre es detenido y juzgado, y los hijos son enviados a una escuela especial para que estén protegidos:

... Brought

To Court, the little screaming boy

And girl were quickly, for the public good,

Committed to Industrial School.

The cost - three pounds a week for each:

Both safely held beyond the reach

Of mother, father. We destroy

Families, bereave the unemployed.

Pity and love are beyond our buoys. (10-18)

La sátira de Clarke aflora por todo el poema, pero especialmente en "Both safely held beyond the reach / Of mother, father", como si éstos fueran los responsables de una política gubernamental que no puede dar trabajo a sus propios ciudadanos. Surge sin duda una pregunta, ¿es preferible que el gobierno dé sustento a unas 
criaturas cuyos padres no pueden alimentar o debería hacer éste todo lo posible para mantener a la familia unida procurando un empleo a los padres? Responder a esta pregunta entra dentro del ámbito de la Ética, y no es materia de esta tesis; Clarke, sin embargo, sugiere que es responsabilidad del gobierno mantener a la familia unida. Lo contrario sería ir en contra de los propios dogmas de la Iglesia Católica, que siempre ha mantenido sus ojos fijos en la unidad familiar.

Pat Rourke, el protagonista del poema que acabamos de ver, es un excelente ejemplo de pobreza, triste distintivo que ha marcado la historia de Irlanda. En el siglo XX, O'Casey, O’Duffy, Sarr, O'Flaherty y Joyce, por nombrar sólo a unos pocos, reflejaron en sus escritos las condiciones infrahumanas en que se vivía en el Dublín de los primeros años del siglo: familias hacinadas en diminutos habitáculos donde la pobreza y la miseria compartían mesa. Desde la constitución del Estado Libre hasta mediados del siglo, los gobiernos respectivos no dieron demasiada prioridad a la sanidad y al bienestar social. El poco desarrollo en estas áreas fue debido principalmente a la depresión económica y a la reticencia de las autoridades centrales y locales a subir los impuestos. A partir de los años treinta, el gobierno de Fianna Fáil emprendió un plan de mejoras sociales, entre las cuales se hallaban medidas de desempleo más generosas, y cuya intención era elevar el nivel de vida de viudas, huérfanos y pensionistas. Sin embargo, "Official attitudes continued to be predicated upon a distinction between the deserving and undeserving poor" (Connolly, "Social Welfare" 518). 
Durante los años sesenta, se empezó a notar una mejoría en la seguridad social, a la vez que aumentaban los beneficios sociales dirigidos a esposas abandonadas, esposas de prisioneros y madres solteras. También es cierto que durante las décadas de los años sesenta y setenta, hubo un considerable desarrollo urbanístico y mucha gente alcanzó niveles de vida inimaginables en el pasado. Sin embargo,

Despite the economic improvements of the last two decades, poverty, particularly in the inflation-dogged seventies, has scarred the lives of many Irishmen and women in years when social progress, the outcome of increased opportunities in a modernizing society, was assumed to be a primary contemporary fact. (Brown, Ireland 264).

Y sigue afirmando Brown que durante los años setenta, al menos una cuarta parte de la población, y quizás cerca de una tercera parte, vivía debajo del nivel de pobreza estimada sobre niveles de ingresos que aseguraban una cierta seguridad social (265).

No es de extrañar, por tanto, que Clarke dedicara parte de su sátira a criticar a un gobierno que no daba al problema de la pobreza su debida consideración. En "In O'Connell Street" (430), otro poema sobre las injusticias sociales, sus protagonistas son gente pobre que ha sido desahuciada. El artificio satírico que emplea Clarke es nuevamente la comparación. Empieza el poema mostrando la 
riqueza y ostentación que simboliza el lujoso edificio de Liberty Hall ${ }^{42}$, y lo utiliza Clarke para proyectar sobre él toda la miseria y pobreza de los ciudadanos que deambulan por las calles de Dublín. Los versos "New lights in the fifth and eleventh storeys / Of Liberty Hall" (2-3), contrastan estridentemente con la verdadera realidad que observa el poeta:

... I saw a procession of forty

Or more poor people, shabby, ill-fed,

Struggling along with hope, unfed up,

In the middle of the street, some holding

Torn bits of paper and old cardboard;

Few on the pavement, hardly a car.

'Our babies die!' 'We have no homes.' (11-17)

Después de presentar la escena, Clarke lanza una invectiva contra el gobierno y sus políticos, que representan a los ciudadanos de la ciudad y ante quienes deberían mostrar más consideración que la que manifiestan al instalar a los pobres y desempleados en penosas viviendas, decretando, además, un toque de queda:

They had been put out

(But politicians are never put out)

And housed in an old British barracks,

Chill dormitory, one gas-stove, W.C.

Men, women, apart: the big door barrred

At ten o'clock. (18-23)

\footnotetext{
${ }^{42}$ Liberty Hall era el "Cuartel general del sindicato Irish Transport and General Worker's Union, inaugurado en 1965 en Dublín. El anterior edificio de 1820, escenario de importantes acontecimientos como el cierre patronal de 1913 y la Insurrección de 1916 ... fue reemplazado por otro de 17 pisos, el primer rascacielos de la ciudad de Dublín" (Hurtley et al 187).
} 
Y como en el poema anterior, los hijos de estas personas son enviadas a escuelas especiales pagadas por el Estado:

Their children were sent to Industrial

Schools, paid for by the State, our Bedlam

Of faith and charity. (25-27)

El sustantivo "Bedlam" - lugar de gran confusión - engloba tanto al Estado como a dos de las tres virtudes teologales, más propias de la Iglesia, y define sarcásticamente lo que Clarke piensa de quienes dirigen la nación, particularizando su ataque sobre el Ministro de Sanidad, Mr. O’Malley.

"New Liberty Hall" (429) es un perfecto compañero para el poema anterior. Los conflictos entre riqueza y pobreza, capitalismo y desempleo, y la dedicatoria a James Larkin ${ }^{43}$ y el lujo del que disponen sus sucesores forman el hilo conductor del poema. Los ataques irónicos se suceden. Primero contra el capitalismo:

$$
\text { ...With cap }
$$

On simple head, hallmark

Of sweat, new capitalists

Rent out expensive suites

Of glassier offices. (6-10)

Luego contra la explotación de los trabajadores:

t3 James Larkin (1879-1947) fue un "Sindicalista, dirigente obrero y cofundador del Irish Citizen Army. ... En 1909 fundó en Dublín el sindicato Irish Tansport And General Workers' Union. ...Estuvo encarcelado en Estados Unidos por sus actividades sindicalistas ... y excarcelado en 1923, regres6 a Dublín y fundó el sindicato 'Workers' Union of Ireland'.... Fue elegido diputado del Dáil en varias ocasiones pero siguió dedicándose .... a las actividades sindicalistas" ( $c f$. Hurtley et al 181182). 
Workers must skimp and scrape

To own so fine a skyscraper. (13-14)

La tremenda ironía del poema reside en la propia idiosincrasia de un emblemático edificio que no sólo albergó las actividades sindicalistas de James Larkin, defensor a ultranza de los derechos de los trabajadores, sino que fue también el edificio de donde salieron las tropas que dirigió James Connolly en la Insurrección de Pascua de 1916. Ahora, un edificio que siempre había cobijado bajo su sombra los derechos del trabajador, se ha convertido en símbolo de riqueza y de prosperidad.

Clarke echa mano de héroes sociales y los utiliza como correlatos objetivos para comparar el pasado con el presente y para criticar la ausencia de los valores que esos hombres encarnaban en su época. Empecemos por "Wolfe Tone",44 (208):

He called a conquered land his own

Although he never bowed at Mass

Behind locked door or knelt on grass.

But we are taught now to disown

Him. Faith needs more than bite and sup.

What may we do but rattle his chains

\footnotetext{
"Varias anotaciones sobre Tone:

a) Clarke comenta en sus notas a $C P$ (1974): "The father of Irish Republicanism and leader of the United Irishmen is now regarded with suspicion. When I was a student there was a marked site for a memorial to him outside St Stephen's Green.... A similar site for a Thomas Davis statue has been kept for some years at College Green opposite the eighteenth-century Houses of Parliament. I wrote these lines on the morning that the fine Gough Monument in the Phoenix Park was blown up" (549550).

b) Según Maxton, a Theobald Wolfe Tone (1763-98) y a Thomas Osborne Davis (1814-45) se les ha conmemorado con sendas estatuas en St Stephen's Green, Dublin. Clarke coloca a Wolfe en el lugar reservado para Davis (223-24).

c) Tone fue arrestado en 1798 y llevado encadenado hasta Dublín donde se le juzgó por traición. Eludió a sus captores suicidándose con una cuchilla.
} 
At College Green, despite cut veins?

We cannot blow his statue up.

Wolfe Tone era protestante, por lo que no tuvo que sufrir las terribles consecuencias de las Leyes Penales. Clarke logra su ataque poniendo en evidencia el desprecio que exhibe la Irlanda actual hacia uno de los padres fundadores de la República. Las causas del deshonor implícitas en el poema son la de haber sido protestante y la de haberse suicidado cortándose las venas. La rima entre "own" y "disown" enfatiza la injusticia y la ingratitud hacia su persona (Harmon, AC 150). En "The Trial of Robert Emmet"45 (208), la sátira es más efectiva, y funciona de nuevo a través del artificio del correlato objetivo, que degrada las condiciones de la Irlanda de los años 50 . El poema propone celebrar de nuevo el juicio de Emmet en el juzgado de Green Street, pero como si fuera una obra de teatro:

See British greed and tyranny defied

Once more by that freethinker in the dock

And sigh because his epitaph remains

Unwritten. Cheer revolution by the clock

And lastly — badge and holy medal guide

Your cars home, hooting through our dirtiest lanes. (9-14)

\footnotetext{
${ }^{45}$ La nota de Clarke en CP (1974) dice: "All the arrangements had been made for the mock-trial, when this sonnet was published in the Irish Times. As the courthouse is not large, high prices were to be charged for the seats. Fortunately the Judiciary protested and, after some weeks of patriotic delay, the Minister for Justice stopped the project" (550).

Robert Emmet (1778-1803) dirigió la segunda rebelión de los United Irishmen de Julio de 1803, que fue un fracaso. Fue arrestado, juzgado y ejecutado. Antes de oír su sentencia de muerte, pronunció un discurso que ha pasado a la historia del nacionalismo irlandés. Emmet pidió que no se escribiera su epitafio hasta que Irlanda no ocupase su lugar ente las naciones del mundo ( $c f$. Hurtley et al 97 ).
} 
En estas líneas la palabra clave es "sigh", que expresa, por un lado, el pesar de que Irlanda no ha ganado todavía independencia, y por tanto el epitafio de Emmet no puede escribirse, y, por otro, el juicio de Clarke sobre el público que está viendo la obra de teatro y no ve que la tiranía británica ha sido reemplazada por la avaricia y la tiranía irlandeses: 'See British greed and tiranny defied / once more'. Clarke utiliza la representación del juicio como metáfora de las condiciones sociales y políticas de su época. Después de la parodia del juicio, Clarke se imagina a la gente yendo hacia sus casas y "sees the Irish as lulled by a shallow nationalism and the false comfort of their religion into turning their backs on the social needs of fellow human beings" (Schirmer, PAC 73). Es precisamente "dirtiest lanes" lo que expresa las desigualdades sociales que tanto las insignias como las medallas piadosas ignoran.

Otro poema contra la tiranía de la Irlanda de Clarke es "Nelson's Pillar"46, Dublin" (209), poema que, según Maxton, responde a la sugerencia de retirar la estatua de Nelson porque no era propio que un almirante británico adornara el monumento más alto de la ciudad y reemplazarla por una de la Virgen María (226). Clarke, con toda su ironía, actúa de abogado del diablo y expone el argumento contrario:

No, let him watch the sky

With those who rule. Stone eye

\footnotetext{
${ }^{46}$ "Columna dórica de 40 metros de altura, rematada por una estatua de Nelson, erigida en Dublín en 1808 para conmemorar la victoria de Trafalgar. Estuvo emplazada en Ackville Street, delante de la Administración Central de Correos.... Fue volada por el IRA en marzo de 1966, al celebrarse el cincuenta aniversario de la Insurrección de Pascua" (Hurtley et al 225).
} 
And telescope can prove

Our blessings are above:

Capital for a few,

For patriots in queue,

The narrow way, turnstile

And shilling stair. (1-8)

Está comparando de nuevo un símbolo de la tiranía británica con la de su propio país. "Stone eye" y "telescope" se refieren respectivamente a la pérdida de un ojo de Nelson y a su famoso telescopio. También "Stone eye" puede referirse a la mirada granítica de la estatua. Las siguientes líneas son ironía manifiesta: las bendiciones del país son el capital para unos pocos, y el "camino estrecho" y difícil, con su referencia cristiana a las palabras bíblicas, para los patriotas.

Y en la historia de Irlanda no sólo había patriotas masculinos. Clarke en su poesía ha mostrado siempre una especial sensibilidad hacia la mujer irlandesa, y no olvida en sus correlatos históricos a ese gran número de mujeres que, más de forma anónima que manifiesta, han ocupado un lugar importante en las páginas de la historia de Irlanda. Así, con la ayuda de estas heroínas, Clarke continúa criticando una Irlanda que ha perdido los ideales que lograron que la República de Irlanda no fuese tan sólo un sueño. "The Subjection of Women" (433) trae a la memoria a Maud Gonne $e^{47}$, símbolo del nacionalismo irlandés y defensora de la gente que sufría el injusto sistema arrendatario: "O she confronted the evictors / In Donegal,

\footnotetext{
${ }^{47}$ Maud Gonne (1866-1953) "Nacionalista, sufragista y célebre actriz. ... Participó en diversas causas desde su temprana juventud. ...Mantuvo una estrecha relación con W.B. Yeats." (Hurtley et al 12526).
} 
our victory" (16-17); evoca a Constance Gore-Booth que, conocida como Countess Markievicz y seguidora del socialista James Connolly, vistió el uniforme verde del Irish Citizen Army en la Insurrección de Pascua de 1916:

...She knew what their poverty meant

In dirty laneway, tenement,

And fought for new conditions, welfare

When all was cruel, all unfair. (32-35)

Rememora a Helena Moleney y a Louie Bennet, activistas en los sindicatos de Irlanda:

Unioned the women workers bent

At sewing machines in the by-rooms

Of Dublin. (56-58)

Revive a Eva Gore-Booth, hermana de Constance y también activista de la causa socialista:

Who spoke on platform, at polling-booth,

In the campaign for Women's Suffrage, (65-66)

Hanna Sheehy, Mary Wollstonecraft, y Dr. Kathleen Lynn son otras mujeres notables que dieron su vida por su país, y éste ahora las relega al olvido:

Women, who cast off all we want,

Are now despised, their names unwanted,

For patriots in party statement

And act make worse our Ill-fare State.

The soul is profit, Money claims us.

Heroes are valuable clay. (86-91) 
El poema es una elegía por los ideales de estas mujeres y un lamento por una Irlanda que, a los ojos de Clarke, ha perdido la fe en sus ideales a cambio de un materialismo feroz: "The soul is profit. Money claims us" (90).

Clarke no duda en criticar la situación social y política de su país, ya sea mediante el correlato histórico o mediante sucesos reales acaecidos durante su vida. En palabras de Harmon, "he always condemns injustice and cruelty, whether seen in the eviction of the poor, [or] the discovery of an old woman suffering from hypothermia" ( $A C$ 222). Un claro ejemplo de esta preocupación de Clarke por los más necesitados es "Miss Rosanna Ford ${ }^{48 "}$ (436), poema que nos muestra a una pobre mujer soltera que muere sola y congelada porque no tiene una moneda para calentar la casa donde vive:

Half dressed, almost deceased on the floor,

Because she had no shilling for the gas,

Blue-handed, freezinfi, Miss Rosanna Ford lay. (3-5)

La pobre señorita Ford vivía en unas condiciones deplorables e indignas de un gobierno que debería hacer llegar su política social a todos los rincones de la sociedad. Miss Rossana Ford vivía sola y era otra de tantas solteras a las que la vida no quiso o no pudo sonreír con siquiera algún vínculo familiar; igual que otras protagonistas de la poesía de Clarke - Martha Blake y Miss Marnell son dos ejemplos que ya hemos visto - y sin apenas dinero para poder cuidar de ella misma - "So indigent she seldom could afford / Sufficient warmth or food for the 
cupboard shelf" (10-11) - Miss Ford vivió seguramente una vida triste y solitaria, suspendida en la parálisís existencial de Dublín, y murió una muerte más triste y solitaria si aún cabe. Martha murió sola en una cama de hospital, sin tan siquiera consuelo espiritual; Miss Marnell, aferrada a las cuentas de un rosario murió de una parálisis cerebral. Clarke no puede permanecer inmune a tanta desgracia. En las últimas líneas, nos deja ver tanto la crueldad del invierno, que se llevó la vida de esta octogenaria, como la insensibilidad de las Navidades que, al igual que la muerte de Miss Rosanna Ford, quedarán pronto olvidadas.

The window whitely fronded by Arctic wind:

Outside the passing motor cars, the Ford vans,

Were hushed by the funeral of the late snow.

A church-bell, tongue in cheek, remarked the date

And Christmas presents in fashionable stores,

Dropping their pretty veils of crepe, vanished. (13-18)

Al igual que las solteras mencionadas, la joven del siguiente poema es otra muestra de indigencia, que de nuevo yace abandonada y lejos de la mano de las instituciones: "Emancipation" (203),

That wretched girl still wakes me up

At night, for all she wore had been thrown

Away. I see her by O’Connell Bridge

And think: 'Yes, more than a century

Ago, religion went in such rags here.'

\footnotetext{
${ }^{48}$ Clarke no contribuye con ninguna anotación sobre este poema. Sin embargo, Maxton (220) proporciona el artículo del periódico de donde Clarke obtuvo la noticia. La fecha de la muerte aparecía en latín debajo del título en un manuscrito del poema: obiit 14 Dec 1966.
} 
Como dice Tapping, "there are fangs in that metaphorical parallel to the Church" (175). Parece que es condición humana olvidar el pasado. La referencia a la época en que la Iglesia Católica erraba proscrita y, en palabras de Clarke, vestía harapos no es en absoluto baladí. Así, no es de extrañar que tanto la Iglesia como el Estado sean las dianas de los ataques de Clarke. Ambas instituciones sufrieron en su propia carne lo que ahora tratan de ignorar. En "The Eighth Wonder of Ireland" (288), el artificio satírico es la degradación sistemática de las acciones de ambas instituciones, para lo cual Clarke recurre al topos literario del "mundo al revés". Éste consiste en una representación burlesca de la realidad en la que las funciones de los seres están trocadas. Clarke subvierte el mundo de Irlanda convirtiéndolo irónicamente en la octava maravilla de su país. El poema empieza con una referencia a Giraldus Cambrensis ${ }^{49}$ y a las que este historiador cree que son las siete maravillas de Irlanda: una espesura vegetal impenetrable, una campana -metonimia de la Iglesia- cuya piedad cojea, un sacerdote que se bebe el vino de misa, un remolino que destroza todo a su paso, un salvaje semental frunciendo el ceño en el prado, una cruz que amenaza a los que testimonian en falso, y una pócima contra la mordedura de reptiles.

\footnotetext{
49 También conocido por el nombre de Gerald of Wales (1146-1223). Fue un historiador de la invasión Anglonormanda, que no se caracterizó por retratar a Irlanda de una forma favorable. De hecho, "his work inaugurated the colonial historiographical tradition of a negative portrayal of the Irish, and was to be relied on heavily by subsequent Anglo-Irish and English writers, and stimulated an apologetic response from native authors: Geoffrey Keating's Foras Feasa ar Éirinn, for example, devoted considerable attention to refuting Gerald's portrayal of the Irish"(cf. The Oxford Companion to Irish History 221)
} 
La octava maravilla - el mundo al revés - la añade Clarke, y ofrece una agria y amarga visión de la Irlanda contemporánea:

To the seven wonders of Ireland, add an eighth.

Thrones and Dominions have changed our copybooks.

Crooked is straight, upside is down, pothooks

Are hangers, good is bad now, pity, cruel,

Free medicine, school-milk, contrary to Faith;

The old, the sick, cannot have soup or fuel,

Parents, who anguish vainly to support

Their infants, are robbed of them, unhomed in Court,

Pelfing is grace, substance of self, a wraith. (16-24)

Giraldus no habría realizado un retrato tan negativo de Irlanda. Estas líneas parecen el resumen de toda la sátira clarkeana: hacen referencia a los niños que las instituciones hurtan a padres indefensos ante la fe católica y la ley civil, a la ausencia de una medicina que llegue a todos los rincones de la sociedad, a la indigencia, a la falta de humanidad de las instituciones, etc. La octava maravilla es una en la que la identidad no existe, sino que se ha convertido, en palabras de Clarke, en un espectro: "a wraith".

Como dijimos en el capítulo II, el pasado es otra de las constante de la poesía de Clarke. "Past and Present" (209) contrasta el respeto que se tenía por la educación en el pasado, cuando ésta estaba prohibida y el país se encontraba sumido en la pobreza más absoluta, con el desprecio contemporáneo hacia la cultura, que se ha sustituido por una ingente preocupación por las nuevas modas, 
por lo superficial, por el consumismo y materialismo que invaden la Irlanda de

Clarke:

Although she went in pitiful tatters,

Her sons were trained in France and Spain.

But fashion in wear is all that matters

To-day. Our anguish was in vain. (1-4)

Better put by our history books

And gape, for now that lashings of pence

Are pounds, a word can give offence. (7-9)

Clarke se lamenta de que las miserias que sufrieron en el pasado no han servido de nada: los libros de historia se han cambiado por el materialismo que, a su vez, coarta la libertad de expresión. La paradoja reside en el hecho de que aunque Irlanda ha vuelto su mirada hacia la reluciente apariencia del capitalismo, la pobreza sigue vagando por sus calles. Clarke, al igual que Swift hizo en $A$ Modest Proposal, propone en el siguiente poema que los irlandeses se coman sus propios caballos: "Knacker Rhymes" ${ }^{50 "}$ (222), título ya de por sí irónico - "Las rimas del matarife de caballos". La sugerencia de Clarke está hecha con la misma aparente sinceridad que la que presentó Swift a los Irlandeses, al proponer que se comieran a sus propios hijos (Schirmer, PAC 99):

\footnotetext{
${ }^{50}$ La nota de Clarke en $C P$ (1974) dice: "Traffic in these sensitive creatures had been quietly and discreetly increasing for some time, but on 17 December 1959, the loss of forty-eight horses at sea during a storm drew public attention to what had been going on.... Instead of advocating total abolition of this new slave trade and appealing to decent citizens, they ask for an export trade in horse meat and are even raising subscriptions to start this new industry. Cars now carry the brutal slogan: 'Stop exporting horses. Start meat factories here"' (551).
} 
Don't ship, kill, can them

First - abattoirs pay- (1-2)

As hand that endorses

The bigger cheques. Irishmen, Taste your own horses! 16-18)

El motivo de este poema, como el mismo Clarke indica en sus notas, es mostrar su desacuerdo con la forma en que se trata a los caballos:

Protection societies, both here and in Great Britain, have chosen the lesser of two evils, thereby showing shortsightedness and remarkable stupidity. Instead of advocating total abolition of this new slave trade and appealing to decent citizens, they ask for an export trade horse meat. (CP 551)

En el poema, Clarke muestra irónicamente el poco aprecio que sentía por estas sociedades, que en vez de condenar el comercio caballar, aconsejan crear mataderos nacionales. A Clarke le gustaría ver a la gente montando sus caballos de nuevo y lo sugiere con ironía y humor:

Forget the horse-slaughter,

Lies, argument, speeches,

And see that your daughter,

Expensively breeched,

Capped, jacketed, learn

How to ride in the suburb (19-24)

And saddle the meat

Dogs, foreigners, eat. (29-30) 
En las últimas líneas trasluce una ligera nota xenófoba, al insinuar que la carne de los caballos que se exporta la comen los perros y los extranjeros, refiriéndose a los que importan los caballos, principalmente británicos.

Clarke también dedicó algunos poemas a criticar y atacar el desarrollo urbanístico que absorbió el barrio dublinés de Templeogue, donde residía el poeta. "Cypress Grove" (285) es un buen ejemplo de la nostalgia de Clarke por el pasado y de su aversión por el progreso que transforma el presente sin mirar atrás:

The sewered city with a rump of suburbs

Has reached the pillared gate in its expansion, Design of the daffodils, the urns, disturbed by Air-scrooging builders, men who buy and sell fast.

One Gallagher bought the estate. Now concrete-mixers

Vomit new villas: builder, they say from Belfast

With his surveyors turning down the oil-wicks.

The shadow is going out from Cypress Grove,

The solemn branches echoing our groan,

Where open carriages, barouches, drove:

Walnut, rare corktree, torn up by machine. (53-63

I stare:

Elegant past blown out like a torchère. (70-71)

El ataque va dirigido a las actitudes materialistas evidentes en "Air-scrooging builders" o "concrete-mixers / vomiting new villas". Aunque el poema parece más una queja personal que una sátira social, el aroma satírico que impregna el pasaje elegido es innegable. Clarke se duele de que en un brusco abrir y cerrar de ojos, el pasado quede borrado para siempre. 
Como hemos visto, la sátira de Clarke fluctúa en su calidad: unas veces es suave y parece tener la fuerza de una simple reprimenda; otras, en cambio, se vuelve mordaz y cruel, y sus blancos salen muy poco favorecidas. Los temas tratados en estas sátiras son en su mayoría hechos puntuales de la sociedad irlandesa. Sin embargo, no dudamos en afirmar que la sátira de Clarke contiene las mismas implicaciones que la de Swift: indignación ante los abusos de poder y ante el desmesurado orgullo del hombre.

Pero aparte de la posible universalidad de los poemas satíricos de Clarke, lo que sí es cierto (y éste es nuestro propósito) es que muestran el eterno conflicto entre la Iglesia Católica, las Instituciones y el individuo, concretamente el individuo irlandés. 
V. LA LOCURA: MNEMOSYNE LAY IN DUST 
En 1919, Austin Clarke ingresa en una institución psiquiátrica, el Hospital de San Patricio ${ }^{1}$ de Dublín, para recibir tratamiento después de sufrir un colapso mental. Previamente, el doctor George Sigerson ${ }^{2}$ le había administrado tratamiento de choque durante un mes, pero no evitó que sufriera una recaída y tuviera que ingresar en el mencionado hospital donde pasó trece meses. El mismo Clarke recuerda el tratamiento de Sigerson y las causas de su enfermedad mental en uno de sus dos volúmenes de memorias, A Penny in the Clouds:

When I came to his house in Clare Street, he gave me treatment with a galvanic battery. Wonderingly, I clutched the brass handles and endured the mild shocks. He told me to come for a regular course and also ordered me to eat black puddings because of their wholesomeness.[...] I attended for a month. Unfortunately, neither the pins-and-needles of the galvanic battery nor the black puddings saved me from collapse in a few months, because there is no cure for the folly of youth or the dire consequences of overindulgence in continence. (42-43)

Clarke, cuarenta y siete años más tarde, relataría su experiencia en el hospital en un largo poema autobiográfico, Mnemosyne Lay in Dust $(1966)^{3}$, aunque poco después de abandonar el centro psiquiátrico, probablemente en 1920, escribió un relato en prosa sobre su experiencia titulado The House of Terror, que nunca se ha publicado.

\footnotetext{
' Este hospital fue la primera institución psiquiátrica en Irlanda. Fue creado en 1757 con dinero de Jonathan Swift. También se le ha conocido con el nombre de Leeper's Hospital (veáse nota $\mathrm{n}^{\circ} 13$ ). Elizabeth Malcolm comenta que era difícil obtener información directa de los pacientes, excepto cartas o anotaciones ocasionales. Sin embargo, "A rare exception to this state of affairs is the poet Austin Clarke, who was admitted to St Patrick's in 1919 suffering from 'melancholia' and was discharged a little over a year later as 'relieved"' (256).

${ }^{2}$ El doctor George Sigerson fue profesor de Zoología en la Universidad de Dublín (UCD), y fue uno de los primeros estudiosos del gaélico.

${ }^{3}$ Este largo poema narrativo se publicó en una edición especial limitada con dibujos de Jack Coughlin, que expresaban el tono del texto.
} 
El manuscrito, que en la actualidad es propiedad de su hijo Dardis Clarke, contiene treinta y siete páginas, de las cuales solo se ha publicado el primer capítulo, "The Gate”, y, como observa Dardis Clarke en su comentario al capítulo mencionado, “....it is obvious that the poet referred to it more than forty-five years later when he came to put down his experience in the verse of Mnemosyne Lay in Dust" (74).

Mnemosyne Lay in Dust es el relato de la crisis nerviosa que sufrió Clarke en su juventud, y nos la presenta a través de una máscara, Maurice Devane, un hombre cuyos lazos con la sociedad y su entorno han quedado rotos. Superficialmente, el poema muestra la lenta recuperación de Maurice bajo el tratamiento del hospital, pero una mirada más atenta a sus versos muestra el análisis de una mente que se desintegra y que entra en conflicto para poder juntar todas las piezas de su mente de nuevo. El protagonista revive el descenso de Clarke al submundo de una institución psiquiátrica. Metafóricamente, el poema narra el arquetípico viaje al Hades, el reino de las tinieblas, donde el protagonista se enfrenta no solo a los médicos y enfermeros que lo someten a todo tipo de vejaciones, sino a sus propios miedos, que lo acosan en pesadillas y alucinaciones, y a su propio cuerpo, que se niega a alimentarse. Llega al hospital sin apetito, sin memoria, y sin deseo alguno de vivir. Al final, sin embargo, consigue emerger al mundo de la realidad completamente curado. En palabras de Harmon, "[it is] an allegory of death and rebirth, the winter of loss followed by the summer of renewal, the disoriented imagination replaced by the rational imagination" (AC 219).

\footnotetext{
${ }^{4}$ Véase W. J. McCormack, In the Prison, 72-5.
} 
El mundo al que desciende Maurice Devane representa asimismo los márgenes de la sociedad y de la conciencia humana, oscuros entornos donde Clarke encuentra el material con el que expresar su particular visión sobre la sociedad. Aunque no podamos etiquetar a Mnemosyne Lay in Dust como una sátira, vale la pena recordar que es el trabajo de un poeta en permanente conflicto entre él, la sociedad y las instituciones que la rigen, por lo que no es de extrañar que la satírica imaginación de Clarke encuentre en el mundo de las instituciones psiquiátricas irlandesas el material de primera mano para exponer los vicios y defectos humanos:

'Mnemosyne Lay in Dust' [is] a poem that takes us to the very margins of society and confronts us with unthinkable truths about human experience. [...] It is in the mad-house and the gaol, where society incarcerates its victims and villains, that the satiric imagination finds its most compelling imagery of subversive marginality. [...] In the hospital Swift founded "for fools and mad" the distressed Maurice Devane endures extremities of physical loathsomeness that are Swiftian in their precise intensity. (Brown, "Satirist" 138)

Mnemosyne Lay in Dust está compuesto por dieciocho secciones cuyas estrofas difieren en cada sección en longitud y forma del resto. Esta variedad formal refleja la desconexión mental de Maurice Devane. Temáticamente, podemos ver el poema como un viaje a una institución psiquiátrica, la estancia en él durante trece meses, y el regreso a la vida normal. El viaje lo provoca una crisis mental que hace que el protagonista pierda la memoria y tenga que luchar para recuperarla. El proceso es difícil y oscuro porque el origen de la enfermedad y las motivaciones del paciente yacen en su subconsciente. El poema describe el violento tratamiento al que es 
sometido en el hospital, así como los sueños y alucinaciones que revelan sus miedos y deseos. En realidad, Maurice Devane se enfrenta a un conflicto de cuyo origen no está seguro y cuya resolución le llevará a la recuperación, es decir, a la unión de los tramos inconexos de su mente que le habían aislado de la realidad. Mnemosyne Lay in Dust, sin embargo, se centra más en recrear la experiencia de la hospitalización o, más bien, encarcelamiento, y en mostrar la violencia institucionalizada, que en la propia recuperación de Maurice (cf. Harmon, $A C$ 205), la cual nos viene dada de forma implícita a través de pequeños detalles que revelan su curación.

En la Sección I, Maurice Devane comienza su viaje hacia el submundo del hospital psiquiátrico:

Past the house where he was got

In darkness, terrace, provision shop,

Wing-hidden convent opposite,

Past public houses at lighting-up

Time, crowds outside them - Maurice Devane

Watched from the taxi window in vain

National stir and gaiety

Beyond himself: St. Patrick's Day,

The spike-ends of the Blue Coat school,

Georgian houses, ribald gloom

Rag-shadowed by gaslight, quiet pavements

Moon-waiting in Blackhall Place. (I. 1-12)

En un estado de semi-inconsciencia, Maurice observa desde el taxi que lo lleva al hospital la celebración del día de San Patricio y la agitación nacional originada por la Guerra de la Independencia. El léxico de la estrofa anticipa la atmósfera de tinieblas 
en la que pronto quedará sumido: "in darkness", "ribald gloom", "rag-shadowed", "gaslight", "Moon-waiting". Después de haber estado seis semanas insomne, Devane se da cuenta de que está perdiendo la noción de la realidad: su inconsciencia, el vacío que hará que pierda su identidad - "Void would draw his spirit / unself him" (I. 1617) -, lo aterroriza. Vagamente es consciente del origen de su enfermedad: la abstinencia sexual: "Life burning in groin / And prostrate ached for a distant joy" (I. 21-22).

A medida que atraviesa parte de la ciudad de Dublín, siente el fragor de la festividad, expresado en imágenes relacionadas con el mundo de la bebida y sus efectos -“Guinness", "Brewing intoxication”, “distilleries”, “jollities”, “Delirium tremens", "Dublin swayed, / Drenching, drowning the shamrock", "Whiskey-allround" - imágenes a su vez que describen su propio estado mental. En el recorrido, va dejando atrás varios hospitales, el King's Hospital ${ }^{5}$ y el Hospital del Dr. Steevens ${ }^{6}$, el hospital público más antiguo de Dublín, y que en cierto modo proclaman la cercanía de su destino: el hospital de Swift o "The Mansion of Forgetfulness", en irónica oposición a Mnemosyne?:

The Ford turned right, slowed down. Gates opened, Closed with a clang; acetelyne glow

\footnotetext{
${ }^{5}$ En el poema aparece con el nombre con que era conocido popularmente, Blue Coat School, sito en Blackhall Place.

${ }^{6}$ Este hospital fue construido por Miss Grisel Steevens en 1733 con los fondos que dejó su hermano, Richard Steevens. Esta familia eran "Cromwellians", y quizás por esta razón Madam Steevens tenía la reputación de tener rasgos faciales semejantes a los de un cerdo, resultado de la maldición que echó una vagabunda sobre su madre (Maxton 246).

${ }^{7}$ En la mitología griega, Mnemosyne es una Titán, hija de Urano y Gea y, según Hesiodo, la madre de las nueve Musas, que nacieron de su unión con Zeus. Es la memoria personificada.
} 
Of headlights. How could Maurice Devane

Suspect from weeping-stone, porch, vane,

The classical rustle of the harpies,

Hopping in filth among the trees,

The Mansion of Forgetfulness

Swift gave us for a jest? (I. 41-48)

El taxi ha llegado a su destino. Las puertas del hospital se abren para recibir al paciente y se cierran con un significativo "clang", más propio de una prisión que de un hospital, y parece señalar que no ha sido hospitalizado, sino encarcelado. Maurice se encuentra ahora dentro de un "Hades" metafórico donde dos imágenes avernales le esperan: "harpies" y "Forgetfulness". Las "arpías" eran vientos tormentosos que llevaban a la gente hacia la muerte, y, en tiempos de Virgilio, pájaros con cara de mujer que adquirieron connotaciones sexuales. En el poema ambos significados son válidos. En primer lugar, Maurice es arrastrado hacia lo desconocido, lo que equivale a su muerte; en segundo lugar, cuando llega al hospital vislumbra unos pájaros en el jardín - "Hopping in filth among the trees"- que él cree que son las arpías que lo están esperando para llevárselo. "Forgetfulness" es una alusión directa al Leteo, el río del infierno, cuyas frías y oscuras aguas conducían al olvido.

La Sección II comienza con una estrofa dominada por un léxico violento: "Straight-jacketing", "sprang", "lock and bolt", "shocked", "plunged", "suffocated", "assailants", "terror-peeling celluloid", palabras que se convierten en anticipos verbales del violento tratamiento que recibirá nuestro paciente. Maurice es literalmente asaltado, desnudado y arrojado a un bañera de agua caliente. El terror y el 
vacío que presagiaba durante su traslado al hospital le dan la bienvenida al mismo tiempo que lo despojan tanto física como mentalmente de toda identidad. La rapidez de la acción es tal, que Clarke la compara con la rapidez de las acciones de Keystone $\mathrm{Kops}^{8}$ :

He sank, his assailants gesticulating,

A Keystone reel gone crazier;

The terror-peeling celluloid,

Whirling the figures into vapour,

Dissolved them. All was void. (II. 6-10)

Ahora es cuando se encuentra plenamente instalado en el umbral de su locura. Después del baño, es sedado, y comienzan sus alucinaciones y pesadillas: en una palabra, emprende un viaje por el horror que mora en su mente enferma. En el hospital, Maurice no es sólo un paciente más, sino una víctima de sus miedos y de los crueles métodos que se aplican a los que son encerrados en esta institución?. Como dice Harmon,

In other poems Clarke has exposed examples of cruelty and insensitivity; in Mnemosyne that concern turns with determination upon the humiliation and cruelty meted out to those unfortunates who were committed to the care of mental institutions and became victims of an

\footnotetext{
${ }^{8}$ Los "Keystone Kops" fueron unos famosos personajes del cine mudo: "Riotously rough and tumble, creating slapstick mayhem and buffoonery wherever they went, Mack Sennett's Keystone Kops were the kings of early silent comedy. The original seven Keystone Kops were George Jesky, Bobby Dunn, Mack Riley, Charles Avery, Slimm Summerville, Edgar Kennedy and Hank Mann. Mann played police chief Teeheezel for only a short while before he was replaced by comedian Ford Serling, the most famous Kop of all. They made their debut in Hoffmeyer's Legacy (1912)" (www.allmovie.com).

${ }^{9}$ Véase nota $\mathrm{n}^{\circ} 13$.
} 
inhumane system so that their private anguish was exacerbated by the ways in which they were treated. (AC 207)

En sus visiones recuerda varios incidentes ${ }^{10}$ en los que la violencia es la protagonista principal. En una de ellas contempla el descarrilamiento de una locomotora. Gritos de hombres y mujeres, quejidos, humo, acero retorcido, ruido de ambulancias dan paso a otra visión en la que una escandalosa muchedumbre grita "Murder! Murder!", al mismo tiempo que unas mujeres atormentadas se sujetan el vientre y se retuercen mientras dan a luz hijos bastardos, y la policía arremete sin compasión contra la gente.

En un momento de lucidez, Maurice despierta, mira a su alrededor y se da cuenta de que lo están espiando. Su excesiva atención al detalle muestra que no está totalmente perdido. La pérdida de memoria no es total ya que logra mantener el contacto, aunque interrumpido, con la realidad y con el pasado y, por tanto, con su propia identidad:

\footnotetext{
Maurice had wakened up. He saw a

Circular peep-hole rimmed with polished

Brass within the door. It gloomed.

A face was glaring into the bedroom

With bulging eyes and fierce moustache.

Quicker than thought, a torchlight flashed

From wall to pillow. Motionless,

It spied until the face had gone.
}

\footnotetext{
${ }^{10}$ El primero se refiere a un accidente de tren que ocurrió en la estación Westland Row de Dublín. El suceso de la policía puede referirse a una famosa carga policial durante la huelga de 1913 contra simpatizantes de Jim Larkin (Maxton 247).
} 
The sound of sleepers in unrest:

Still watchful, the peep-hole shone. (II. 31-40)

"Gloomed" y "shone" indican figurativamente cuando la mirilla está siendo usada. Su lucidez, sin embargo, no siempre es benévola con él. En la quinta estrofa de esta sección, oye ruidos en el pasillo que logra identificar, "Four men were carrying a coffin / Upon their shoulders" (II. 43-44), y al sentir cómo el frío de la muerte le sube por sus extremidades, inevitablemente piensa que "Those shoulderers would come for him with / The shroud, spade, last thud" (II. 49-50). La idea de la muerte está aferrada a los deteriorados recovecos de su imaginación. El lugar donde se encuentra es frío, aséptico, rayano en lo tenebroso, morada donde reinan la oscuridad y el olvido, y donde los internos con los que comparte el aire que respira le son igualmente hostiles:

Nightly he watched a masquerade

Go by his cell and was afraid

Of one - the stooping, bald-headed madman

Who muttered curse after curse, his hands

Busily knitting, twiddling white reeds:

So huge, he seemed to be the leader.

The others tormented by their folly,

The narrows of the moon, crowded

Together, gibboned his gestures, followed

That madman knitting reed, brow. (II. 51-56)

Maurice se encuentra confinado en una habitación en la que su identidad no existe, es sólo un vacío: “...He wondered who / He was, but memory had hidden all” (II. 6768). Alguien ajeno a él y sin identificar le murmura "Think!” (II. 70), para que active su memoria y, por tanto, para que supere la falta de existencialismo que le domina, es 
decir, "[to] overcome the anonymous blankness in which he exists" (Harmon, $A C$ 207). Una tarde en que observa la realidad que le rodea, echa un vistazo a su alrededor y contempla el abandono y el anonimato que se manifiestan en el dormitorio. Se apresura a mirar por la ventana al jardín que se extiende ante sus ojos, pero "He stared in wonder from his bars, / Saddened by the boughs" (II. 89-90). El jardín que ahora le produce tristeza y abatimiento será más adelante en el poema uno de los elementos clave en la recuperación de su identidad.

Sus observaciones continúan en la Sección III, donde Maurice continua descubriendo y juzgando el lugar en donde lo han encerrado. La sensación es de aislamiento; mira a través de los barrotes de la ventana de su habitación y se da cuenta de la soledad y el abandono en que están sumidos los demás internos del hospital:

Men were looking up

At the sky

As if they had lost something

They could not find. (III. 1-4)

Maxton establece un paralelismo entre esta sección y "The Ballad of Reading Gaol" de Oscar Wild ${ }^{11}$, en la que el autor critica el sistema penitenciario británico y la crueldad de una sociedad tan culpable como los reclusos de la cárcel de Reading. No solo se parece temáticamente sino también en forma:

I never saw a man who looked

With such a wistful eye

\footnotetext{
"Wilde estuvo en la cárcel de Reading en mayo de 1896, el mismo año en que Clarke nació (Maxton 247).
} 


\section{Upon that little tent of blue}

Which prisoners call the sky. ${ }^{12}$

La simpleza léxica de ambos poemas ayuda a transmitir la sensación de desamparo y desolación de los internos, paseantes sin rumbo que buscan impotentes en ese trozo de cielo la vida que se les detuvo en seco al cruzar los muros de sus respectivas prisiones: "They wandered slowly, pallid dots / Faces gone blind" (III. 7-8). Miran hacia arriba desde donde Maurice les saluda en vano, porque no lo ven o no le hacen caso - "Why / Should they pretend they did not see him?" (III. 14-15). La sección "provides a point of stillness within the poem's welter of activity, while giving one of Clarke's most definitive statements on the alienating forces of madness" (Martin, "Technique" 101).

Pero antes de continuar con la siguiente sección, es necesario advertir de que aunque casi todos los sucesos que relata Clarke en el poema se refieren a su experiencia en el hospital, el poema es ante todo una obra de arte que está ficcionalizada, por lo que no es de extrañar que aparezcan licencias poéticas que difieran de la realidad. El poema, además, funciona como alegoría en la que se puede reconocer la alienación que sufre el hombre moderno del siglo veinte y, en concreto, el hombre moderno irlandés. Malcolm advierte al lector de que lea las líneas de Clarke con cuidado, y de que no olvide que está leyendo ficción,

In 1966 Clarke published a long poem, entitled Mnemosyne Lay in Dust, which, amidst accounts of memories and dreams, included a number of vivid cameos of hospital life from the patient's point of view. Such a first-hand description is of course very valuable but, nevertheless, it

\footnotetext{
${ }^{12}$ Brendan Kennelly, The Penguin Book of Irish Verse, 278.
} 
needs to be treated with some caution. We must remember firstly, that it is a work of art, not a factual account; it does not aspire to accuracy of detail. Secondly, the poem appeared more than forty years after the events it deals with occurred. For both these reasons, the work's factual accuracy must remain in doubt. Even given these reservations, however, the poem still offers a fascinating perspective on hospital life. For one thing, it refers to and describes staff and patients by name. [...] Mnemosyne Lay in Dust is undoubtedly an idiosyncratic view of St Patrick's, but it does convey various features of patient life from the patient's perspective; a perspective different from, but no less valuable than the ones found in the governors' minute books or the superintendent's reports. (256)

En la Sección IV, Maurice describe a sus doctores, quienes, paradójicamente, son una fuente de terror para él. El Dr. Leeper ${ }^{13}$ — "ready to leap" (IV. 3) -, "mad-eyed" Dr. Rutherford $^{14}$, y el superintendente, Mr. Rhys ${ }^{15}$ - "ready to pounce ... with his band of seizers" (IV. 8-9)-, son los causantes de su obsesiva preocupación por detalles nimios como la posición de una pastilla de jabón que aparecía en distinta posición. El léxico de la segunda estrofa - "trap", "spy", "suspicions", "foes"- confirma su inquietud:

\footnotetext{
13 Richard Leeper fue nombrado superintendente médico en 1899, y durante cuarenta años fue un vigoroso reformador del hospital (cf. Maxton 247). Su popularidad fue tal que se conoció al hospital como "Leeper's Hospital". "Moreover, this change of name represented a real change in the nature of the institution: from a decaying home for elderly incurables, firmly rooted in the past, St Patrick's became, under Leeper's guidance, a hospital making serious attempts to keep abreast of modern developments in treatment and to apply these to its patients. Leeper re-introduced psychiatric medicine into St Patrick's, which, in the decades immediately prior to his appointment, had merely been caring for the basic physical needs of patients. Many of the treatments employed by Leeper have subsequently been superseded, if not actually discredited, but this fact should not detract from his very considerable achievement (Malcolm 257).

${ }^{14}$ H. R. C. Rutherford sirvió como jefe de asistencia médica desde 1906 a 1925 (Maxton 248).

${ }_{15} \mathrm{Mr}$. Rhys fue superintendente durante 1919-20. No era médico (Maxton 248).
} 
...the soap-dish had

Been moved an inch. Was it a trap

To test his observation? Cuting,

He put it back, for he was sure

It was a spy. Yes, his suspicions

Were right. But would he not forget

Next day where he had moved the soap-dish,

What other trap his foes would set? (IV. 13-20)

Aunque su poder de observación no está del todo menguado, Maurice no consigue reconocerse a sí mismo ni darle sentido a sus observaciones. A menudo se mira en el espejo y no identifica la imagen que en él aparece: "He seemed to know that bearded face / In it, ... Who was it? Nothing came to him" (IV. 23-24, 27). De lo único que está seguro es del presente, "Sunlight was time" (IV. 31), a partir del cual se atreve a establecer confusas conexiones con el pasado, en especial con su niñez y adolescencia. Sus asociaciones son visuales y sonoras. Los recuerdos de la estrofa cuarta desbordan domesticidad: "the quiet voice of steam / Drowsy machinery", "footsteps", "hissing / And lisp of steam in the laundry"; y rutina: "A student again", "Class-books", "granite wall", "Grangegorman"16 (que no reconoce como "Richmond Asylum"), y que son imágenes cotidianas de su infancia. Sin embargo, cuando su memoria parece tramar algo, es decir, dispuesta para recordar - "memory afoot"-, Maurice se esfuerza en descifrar los recuerdos evocados, pero su mente produce

\footnotetext{
${ }^{16}$ Este psiquiátrico había sido conocido con el nombre de Richmond Asylum, y se encontraba cerca del lugar donde nació Clarke. Actualmente se conoce con el nombre de St Brendan's Hospital (Maxton 248).
} 
asociaciones distintas, en este caso de tipo religioso, en las que se detectan su ansiedad por la falta de fe religiosa, sus desórdenes sexuales, y la muerte de su padre:

A sound of oriental greeting;

Ramàyana, Bhagavad-gita, Hymnal of Brahma, Siva, Vishnu.

'The temple is gone. Where is the pather?'

A foolish voice in English said:

'He's praying to his little Father.' (IV. 45-50)

Según Harmon, "The references to the Sanskrit epic of Rama ${ }^{17}$ which tells of the incarnation of Vishnu, to the sacred writings of the Hindu, and to a triad of Hindu gods work both positively and negatively" (AC 209). Estas asociaciones religiosas, sensuales e imaginativas quedan rotas al interponerse en medio dos vocablos que apenas tienen sentido entre sí, 'temple' y 'pather'. Esta última palabra, casi idéntica a la inglesa "father", y etimológicamente igual en varios idiomas, se refiere también a "panther", palabra que provee una extraña conexión linguística cuyo significado desconoce Maurice y que a su vez está asociada con Vishnu, a quien se suele representar sentada sobre una piel de pantera o de tigre. Maurice no consigue relacionar sus pensamientos de una forma lógica, pero sus asociaciones con la literatura y la mitología orientales indican una disponibilidad imaginativa que refleja

\footnotetext{
${ }^{17}$ En la mitología hindú, "Rama" se refiere a cualquiera de las tres encarnaciones de Vishnu: Balarama, Parashurama, y Ramachandra. Vishnu era originalmente un dios solar que ocupaba el segundo lugar en el panteón hindú. Más tarde fue uno de los tres principales dioses: Brahma, el Creador, Vishnu, el Protector, y Shiva, la diosa Destructora. También, Vishnu sería más tarde el salvador, que aparecería en múltiples encarnaciones. Ramayana es un poema épico hindú, compuesto alrededor del año 300 a.C., y que relata las hazañas de Ramachandra, una de las encarnaciones de Vishnu. Bhagavad-gita es un texto sagrado hindú compuesto hacia el año 200 a. C., y que fue incorporado al poema épico Mahabharata. Siva o Shiva es también la diosa de la fertilidad y la que preside los destinos personales.
} 
la necesidad inconsciente de Maurice por dar sentido a sus recuerdos. Su pérdida de apetito en la siguiente estrofa es una manifestación del colapso de su voluntad:

Weakening, he lay flat. Appetite

Had gone. (IV. 51-52)

$[\ldots]$

His stomach closed: He eyed the food,

Disgusted: always beef or mutton,

Potatoes, cabbage, turnips. Mind spewed,

Only in dreams was gluttonous. (IV. 57-60)

Después de los recuerdos evocados en la sección anterior, la Sección V relata una serie de sueños y alucinaciones en los que la mente de Maurice sigue batallando entre la irrealidad de sus sueños y el terror que éstos le producen. La interpretación de los sueños no es una tarea fácil, y requiere conocer al individuo y estar familiarizado con sus hábitos y costumbres. De igual manera que el lector ha de estar lo más informado posible a la hora de interpretar un texto, igualmente ocurre a la hora de interpretar un sueño: cuanto más se sepa del soñador, mejor.

Para poder entender las imágenes oníricas de esta sección, vamos a recurrir, aunque sea someramente, a la crítica psicoanalítica. Normalmente el análisis psicoanalítico consiste en dejar que el paciente hable libremente de forma que sus miedos y conflictos afloren a la superficie de su conciencia, en lugar de permanecer ocultos en el subconsciente. Esta práctica se basa en teorías específicas que explican cómo trabajan la mente, el instinto, y la sexualidad humanas. El primero que desarrolló una teoría sobre el psicoanálisis fue el austríaco Sigmund Freud (1856- 
1939), y aunque actualmente las teorías de Freud han mostrado sus limitaciones, no se puede negar su presencia en la cultura occidental del siglo $\mathrm{XXI}^{18}$.

Las teorías de Freud dependen de la noción de subconsciente, que está estrechamente ligada a la idea de represión, definida como,

The 'forgetting' or ignoring of unresolved conflicts, unadmitted desires, or traumatic past events, so that they are forced out of conscious awareness and into the realm of the unconscious. (Barry 96-97)

No vamos a explicar aquí toda la teoría de Freud, ni pretendemos embarcarnos en un estudio psicoanalítico de este largo poema, aunque sería un ejemplo perfecto a juzgar por sus características: conflictos internos, deseos reprimidos, traumáticos sucesos acontecidos en el pasado. Sí, no obstante, vamos a aplicar algunas de las teorías de Freud sobre la interpretación de los sueños, porque es en éstos donde los sucesos reales y los deseos se transforman en imágenes oníricas. El proceso onírico incluye dos factores. Uno es el de desplazamiento, por el que un objeto - ya sea una persona o un suceso-está representado por otro objeto con el que de alguna manera está asociado, quizás a través de una palabra de sonido similar, o por alguna forma de sustitución simbólica. El otro factor es la condensación, mediante la cual una serie de objetos - de nuevo personas o sucesos - vienen representados por una sola imagen. Los sueños, igual que la literatura, tienden a transmitir información de forma indirecta, evitando significados llanos y directos. Pero antes de empezar con el análisis de los sueños de Clarke, conviene hacer referencia a otro importante psicoanalista cuya obra

\footnotetext{
${ }^{18}$ Cf. Barry 96-97.
} 
ha tenido una extraordinaria influencia en la más reciente crítica literaria. Nos referimos al francés Jacques Lacan (1901-1981).

La idea principal de la teoría de Lacan es que el subconsciente está estructurado como el lenguaje. Los estudios modernos sobre el lenguaje empezaron con Saussure, para quien las palabras son signos formados por dos partes, un significante $\mathrm{y}$ un significado, y los elementos del lenguaje adquieren significado a través de contrastes o diferencias entre unas palabras y otras, y no porque haya alguna conexión entre las palabras y las cosas. Los intentos de Saussure por salvar el vacío existente entre significados y significantes fueron en vano. Es ya un lugar común en la teoría lingüística y literaria la existencia de una perpetua barrera entre el significante (la palabra) y el significado (el referente), lo que implica que el mismo significante puede tener varios significados. Así, Lacan identifica el subconsciente con los inestables significantes, cuyos significados son a menudo inaccesibles porque están reprimidos. El signo es para Lacan "a sliding of the signified beneath the signifier" (Lodge, 85), es decir, el significado se desliza bajo el significante que parece estar flotando. Pero, ¿qué evidencia hay de que el subconsciente sea "lingüístico" en estructura como Lacan alega?

Como hemos visto, el mecanismo onírico para Freud estaba formado por dos factores, desplazamiento y condensación, y Lacan asocia estos dos factores con los dos polos básicos del lenguaje identificados por el lingüista Roman Jakobson, es decir, la metonimia y la metáfora respectivamente. En la metonimia, una cosa representa a otra en función de una parte por el todo o basándose en una relación de contigüidad, 
causa o efecto, dependencia recíproca, o desplazamiento de los límites semánticos. Para Freud un elemento en un sueño puede representar algo por medio de un desplazamiento, de forma que una persona puede estar representada por uno de sus atributos: la autoridad del padre por medio de un policía (como ocurre en uno de los sueños de Clarke), por ejemplo. En la metáfora, por otra parte, hay una relación de semejanza y funciona condensando varias cosas dentro de un mismo símbolo. Pero el subconsciente no solo está estructurado como el lenguaje en función de la metáfora y la metonimia: "for the post-structuralists, [language] is composed less of signs -stable meanings - than of signifiers" (Eagleton 168). Realmente lo que hace Lacan es desconstruir el texto, tratando de limitar al escurridizo significado sin llegar nunca a una posible interpretación. Por tanto, no vamos a seguir a Lacan en nuestro análisis porque no es nuestro propósito desconstruir el poema sino analizar el conflicto mental de Clarke / Devane como sinécdoque de la conciencia toda de un pueblo. Así pues, nuestra intención es indagar en los sueños de Clarke echando mano de las teorías de Freud que, aunque tuvieran sus deficiencias, muestran una extraordinaria vigencia a la hora de analizar la poesía de Clarke. A pesar de la oscuridad de algunos pasajes de su poesía, la interpretación de sus sueños nos la da el mismo Clarke a través de los pocos apuntes biográficos que nos legó en sus memorias.

Para Freud, "el sueño es la realización de un deseo reprimido, la realización de un temor o simplemente la reproducción de un temor"19", (422). Para interpretar un

\footnotetext{
19 Todas las referencias a Freud provienen de Sigmund Freud. Obras Completas. Tomo I. Madrid: Biblioteca Nueva, 1981.
} 
sueño ajeno es imprescindible que el sujeto acceda a comunicar las ideas inconscientes que se esconden detrás del contenido de sus imágenes oníricas. En el caso de Clarke y de su máscara, Maurice, solo contamos con la poca información que él mismo revela en sus dos libros de memorias, pero creemos que aportan suficientes datos como para aventurarnos a interpretar los sueños que aparecen en esta sección. No obstante, no hay que olvidar que son los sueños de un hombre que tiene alteradas sus facultades mentales, y averiguar la causa de este trastorno forma parte de su curación.

Muchas de las conclusiones a las que llegó Freud en sus análisis de sueños ajenos mostraban que siempre había un componente de tipo sexual en el sujeto en cuestión. Los sueños de Clarke no son una excepción, y en ellos aparece la frustración sexual como leit motif que compone no solo sus sueños sino, como vimos en capítulos anteriores, toda su vida. Creemos que las causas de esta frustración están tanto en el celibato que la educación clerical de Margaret impuso a Clarke como en el interrogatorio que sufrió en el confesionario cuando era niño sobre su presunta masturbación. En cualquier caso, ambas causas tienen sus raíces en el represivo código moral de la Iglesia Católica, que atormentó a Clarke durante gran parte de su vida, represión a la que contribuyó el régimen de puritanismo victoriano que su madre impuso en el hogar familiar.

Veamos, las primeras estrofas de esta sección V:

Maurice was in an Exhibition Hall

Where crowds of men and fashionable women

In bosoming dresses, embroidered shawl,

Were moving. But a silent form 
Was waiting in a corner. Up marble stairs,

He hurries from mirrored hall to hall, by glimmer

Of statues in niches. The Watcher stares,

Red tabs upon uniform. (V. 1-8)

Again he mounts the steps, alone,

Self followed from mirrors to hall, the crowd

Of visitors waltzing below,

And looking from the bannisters

Upon the billiard tables, playerless,

Green-shaded, saw the Watcher with a frown

Behind a pillar, standing motionless

Casting the shadow of a policeman. (V. 9-16)

En estos versos oníricos aparecen elementos simbólicos que son propios de los sueños que Freud denomina como "sueños típicos". En primer lugar, tenemos el sueño del burdel, en el que aparece el sujeto huyendo a través de una serie de habitaciones (cf. Harmon $A C$ 210; Freud 561), las cuales simbolizan casi siempre mujeres. Asimismo, este sueño podría simbolizar la antítesis del matrimonio, lo cual es perfectamente aplicable a Maurice, si consideramos como causa principal de su colapso mental su continencia sexual con Margaret. Clarke cortejó a Margaret justo antes de su colapso, y se casó con ella cuando fue dado de alta. Frazier expresa el problema de la pareja claramente:

She had received the same clerical education from nuns that Clarke suffered at the hands of Christian Brothers and Jesuits. [...] The experience relived in Maurice Devane's vision seems to be that trauma 
for which all the shames of their common upbringing had prepared them. (“Cod-Bewildered" 58)

En segundo lugar, aparece en las dos estrofas un observador que coarta las acciones de Maurice; es a la vez figura silenciosa, guardián, y policía. Es un agente de la autoridad moral, como el sacerdote en la esfera religiosa y el policía en la secular. Su presencia evita que Maurice muestre un cierto comportamiento sexual, ya sea en forma de masturbación o de coito con una mujer (Frazier, "Cod-Bewildered" 56). Su función es claramente represora, y, en nuestra opinión, simboliza a la Iglesia Católica, que le creó tantos problemas antes y durante su primer matrimonio. Según Harmon, "The dream represents the possibility of sexual adventure but it also represents Devane's sense of exclusion and guilt" $(A C 10)$, es decir, la exclusión de Maurice del juego sexual en la vida real. Maurice está en un burdel intentando disfrutar, pero se ve constantemente observado de forma reprobatoria. Su cuerpo desea mantener relaciones sexuales, pero su mente se lo impide.

Otro elemento importante son las escaleras que Maurice sube y baja: “Up marble stairs", "Again he mounts the steps". Las escaleras, así como el subir y bajar por ellas, son representaciones simbólicas del acto $\operatorname{sexual}^{20}(561)$, y éstas, en el caso de Maurice, representan la realización de un deseo no conseguido: la satisfacción sexual

\footnotetext{
${ }^{20}$ Comenta Freud en su ensayo que algunos psicólogos se habían quejado por la exagerada interpretación que hacía de algunos sueños. Acerca de las escaleras dice: "Esta objeción atrajo mi interés sobre la aparición de escaleras en el sueño, y pronto pudimos comprobar que las escaleras (y todo lo que a ellas se asemeja) constituye un indudable símbolo del coito. No es nada difícil hallar el paralelismo entre el acto sexual y el de subir por una escalera. Ambos tienen común el hecho de que en una rítmica graduación y con una creciente agitación respiratoria se llega a un punto cumbre o lugar elevado desde el cual se desciende luego con rapidez" (561).
} 
con Margaret. Para Freud, "todos los objetos alargados - bastones, troncos de árboles, sombrillas y paraguas - y todas las armas largas y agudas - cuchillos, puñales, picas - son representaciones del órgano genital masculino. [...] Los estuches, cajas, cajones y estufas corresponden al útero, como también las cuevas, los barcos y toda clase de recipientes" (560-561). En estas dos estrofas aparecen "Statues in niches" y "Pillar", que tienen claras connotaciones fálicas.

Todo este simbolismo sexual aparece con más fuerza en el sueño relatado en la tercera estrofa de la sección:

Once, wandering from a hollow of asphodel ${ }^{21}$,

Still flowering at mid-night, he saw the glint of

Gigantic row of columns beyond the dell, Templed, conical, unbedecked

And knew they were the holy ictyphalli

Curled hair for bushwood, bark or skin

Heavily veined. He worshipped, a tiny satyr,

Mere prick beneath those vast erections. (V.17-24)

Aparte de los símbolos fálicos - "columns", "ictyphalli”, 'Heavily veined”, "prick", "erections"- aparecen también símbolos referentes a los órganos sexuales femeninos: "dell", "Templed", “conical", "curled hair". La necesidad de realizarse sexualmente de Maurice aparece confirmada en este sueño, y, según Frazier, la frase 'Mere prick beneath those vast erections'

21 Según Maxton (248), "asphodel" es "a flower associated with death, immortality and blissful forgetfulness", la cual es apropiada en el contexto ya que Maurice teme la muerte y, además, no puede recordar quién es. 
Dramatizes his wish to inhabit a world where the male splendour of masturbation and the communal ecstasy of intercourse are matters of celebration rather than repression. ("Cod-Bewildered" 57)

En realidad, el sueño muestra el terrible conflicto que se libra dentro de la mente de Maurice: su conciencia católica contra sus deseos naturales. El conflicto es idéntico al que las mujeres y el ermitaño de los poemas de Pilgrimage and Other Poems se veían obligados a librar en sus conciencias.

La estrofa cuarta cambia el tono de los sueños y nos presenta un sueño espiritual. En él aparecen un grupo de niños judíos dirigiéndose a la carrera hacia el jardín del Edén y un grupo de niñas corriendo a saltos y apresurándose hacia la puerta de, suponemos, dicho jardín. Clarke no hace demasiadas precisiones al respecto: "Other visions were eastern and I can remember countless Jewish children hurrying at nightfall through an immense gateway into a garden, so exquisite was the olive-andivory of their faces" (TRBC 7). Podríamos interpretar este sueño cómo el deseo de Maurice / Clarke de tener una familia, como parece confirmar la última línea de la estrofa: "Love / Fathered him with their happiness" (V. 31-32). Pero los niños que aparecen en el sueño están muertos - “...their faces pale / As ivory or jasmine, from Lebanon / To Eden" (V. 26-28)-, y por eso los coloca Maurice en el Paraíso. La explicación podría estar contenida implícitamente en las memorias de Clarke en las que relata que provenía de una familia numerosa que quedó menguada por la enfermedad y las circunstancias de la época:

Large families at that time had their own smaller past during her reign [Queen Victoria] because so many children died of infancy. There were 
twelve of us, but Mary Esther or Doto, Eileen, Kathleen and myself were the only survivors, for that was the herodean era. [...] We were constantly aware of the presence of our little brothers and sisters watching us from Heaven, for we knew that God had taken them back so that they might live happily ever after. (TRBC 15)

Este sueño muestra asimismo un marcado simbolismo sexual. Según Freud, "Los niños (los pequeños) suelen también constituir un símbolo de los órganos genitales" (562). No nos ha de extrañar esta posible interpretación, principalmente por dos motivos. En primer lugar, y según Freud de nuevo, en el análisis de los sueños suelen descubrirse las huellas de sucesos infantiles que desempeñan el papel de fuentes oníricas (467). No sabemos apenas nada de la infancia de Clarke, excepto sus problemas con su confesor y con la rígida moralidad de su madre, amén de algunas anécdotas inconexas que nos cuenta en sus autobiografías. En segundo lugar, hay que tener presente su constante obsesión por el sexo, lo cual no es excepcional dado que no ha habido ningún otro instinto en la historia de la humanidad que haya tenido que soportar tantas represiones como el instinto sexual en todos sus numerosos comportamientos, $\mathrm{y}$ de ningún otro perduran tantos $\mathrm{y}$ tan intensos deseos inconscientes (cf. Freud, 587).

En la siguiente estrofa aparece otro sueño que retoma el tono abiertamente erótico de las primeras estrofas. Amplios salones y escaleras recuerdan inmediatamente el sueño del burdel:

Always in terror of Olympic doom, He climbed, despite his will, the spiral steps 
Outside a building to a cobwebbed top-room.

There bric-a-brac was in a jumble,

His forehead was distending, ears were drumming

As in the gastric fever of his childhood.

Despite his will, he climbed the steps, stumbling

Where Mnemosyne lay in dust. (V. 33-40)

Agustin Martin sugiere un posible significado para la profecía olímpica: "The 'Olympian doom' comes I suggest from the terrible proverb that whoever Jupiter wishes to destroy he first makes mad" ("Rediscovery" 101). Harmon opina lo mismo, aunque sin hacer referencia al proverbio ni dar explicaciones: "it is a devastating discovery, a confirmation of the 'Olympic doom' that propelled him forward" ( $A C$ 210). De igual modo, Frazier no nos proporciona demasiada información, y simplemente observa: "But again Maurice must flee in terror "Of Olimpic doom" (“Cod-Bewildered" 57).

Aparte de las sugerencias anteriores sobre el miedo de Maurice a volverse loco (Clarke usa la profecía de Júpiter como correlato objetivo), nosotros proponemos otra interpretación basándonos en la tesis central de la teoría freudiana que sostiene que todo sueño es la realización de algo que se desea. De nuevo encontramos escaleras que, al contrario que en los sueños anteriores, Maurice se ve obligado a subir. Como dijimos, las escaleras simbolizan el acto sexual, pero esta vez Maurice es obligado a realizarlo en contra de su voluntad - "despite his will" se repite dos veces en la estrofa. Fijémonos también en que tiene que subir "spiral steps", que pueden dar la idea de algo difícil o tortuoso para el sujeto. Creemos que la profecía de Júpiter es una 
metonimia de la Iglesia Católica, y el acto sexual, simbolizado por las escaleras, es metonímico - o una condensación, en términos de Freud- de la relación de Clarke I Maurice con Margaret. Las relaciones sexuales en esta pareja no existieron -tampoco durante su breve matrimonio, que quedó sin consumar-, por lo que el intento frustrado de mantener dichas relaciones queda simbolizado en las escaleras de caracol. Cuando llega al final de la habitación que, según Freud simbolizaría a una mujer, encuentra a Mnemosyne, o la memoria, yaciente en el polvo, rechazada, y reprimida: sus prejuicios religiosos lo han llevado a la pérdida de la memoria y lo han postrado en un estado de locura que da fe de la profecía de Júpiter.

Después de la impotencia del sueño anterior, en el que Maurice se ve abocado a la pérdida de la memoria $\mathrm{y}$, consecuentemente, a la de su propia identidad al no poder reconocerse, Maurice sueña que toma parte activa en la Guerra de la Independencia: estamos, esta vez, ante un sueño heroico.

Dreaming, as sunlight idled. Maurice believed

He darted by with sticks of gelignite,

Unbarracked County Limerick, relieved

His felows, fought to the last bullet.

Daring Republicans of hillside farm-yards,

Leader of raiding parties, digging at night,

He blew up lorries, captured British arms.

Rain-hid, he cycled Belmullet. (V. 41-48)

En sus memorias, Clarke recuerda: "In a continual dream-sequence I followed the exploits of a Republican fighter in Limerick and the southern counties and at times his 
breathless escapes seemed mine" (TRBC 7). Claramente, la fantasía de ser un guerrillero republicano afianza el deseo nacionalista de Maurice - desea ver a Irlanda libre del yugo británico- y podemos interpretarlo como una reacción a la pasividad que mostraba en el sueño anterior. El léxico contribuye a mostrar esa actividad que le era negada anteriormente. Así, Maurice "darted", "unbarracked", "relieved his fellows", "fought to the last bullet", "he blew up lorries", "captured British arms", y finalmente, después de arriesgar su vida en acciones militares, consigue ponerse a salvo. Sin embargo, su heroico sueño no dura demasiado porque alguien ajeno a él y que parece encontrarse en la misma habitación que Maurice se encarga de traerlo a la realidad de su condición:

... A melancholy

Man, sallow, with black moustache, sat there.

'Where am I?' Voice was hollow.

The other brooded: 'Think.' His gaze

Was so reproachful, what was his guilt?

Could it be parricide? The stranger

Still murmured: 'Think ... Think.' (V. 50-56)

En varias ocasiones aparece una especie de fantasma inquisitorial que se dirige a nuestro paciente. Este espectro que urge a Maurice a pensar podría interpretarse como su otro 'yo' reflejado en un espejo. Es la misma figura que le ordenaba pensar en la Sección II, y también la imagen reflejada en el espejo de la sección IV. Harmon 
opina que "In Jungian terms he is the shadow", standing for unknown or little-known attributes and qualities of the self" ( $A C$ 211), es decir, las figuras que se dirigen verbalmente a Maurice representan lo que no quiere saber ni aceptar sobre sí mismo. Maurice se pregunta si su culpa podría ser parricidio - el padre de Clarke había muerto cinco meses antes de que éste cayera enfermo- y la siguiente pregunta lo aterroriza, porque no tener padre equivale a no poseer identidad, al quedar el individuo desconectado de su propio pasado. Maurice necesita a Mnemosyne, madre de las musas, para restablecer su relación con la musa de la poesía, y así poder salir del hospital y seguir con su actividad artística.

El temor de haber asesinado a su propio padre deja a Maurice en un estado de evidente aislamiento y con un sentido total de desprotección familiar que sirve de transición para la Sección VI. Ésta comienza con la devastadora alucinación de haber perdido a su madre y sus hermanas, lo que con la muerte de su padre le priva de toda ayuda familiar. Sentirse solo interiormente es lo que coloca a Maurice en una especie de oscuro laberinto del que no puede salir: "I am alone, now" (VI. 6), es la conclusión a la que llega. Esto provoca una violenta reacción que obliga a sus cuidadores a Ilevarlo a una celda acolchada (seguramente para evitar que se hiera a sí mismo) y aislarlo del mundo exterior.

\footnotetext{
${ }^{22}$ En términos de Jung, la "sombra" es uno de los factores estructurales de la personalidad del individuo (los otros dos son "la persona" y "el alma"). La sombra representa "el aspecto considerado negativo y 'sombrío' u oscuro de la personalidad, que incluye no sólo lo no admitido o rechazado del inconsciente personal, sino también todo el problema misterioso del mal en el mundo y los respectivos sentimientos de culpabilidad tanto a nivel personal como colectivo" (Vázquez Fernández 157).
} 
....He left the heat

And stumbled forward, hammered

The door, called out that he was dying.

Key turned. Body was picked up, carried

Beyond the ward, the bedwhite row

Of faces, into a private darkness.

Lock turned. He cried out. All was still.

He stood, limbs shivering in the chill. (VI. 13-20)

Esta estrofa está narrada desde fuera, y en ella el lector ve cómo los enfermeros del hospital cogen al paciente y lo arrojan a una celda circular donde la oscuridad y el terror le son abrumadores. La siguiente, en cambio, está narrada desde el punto de vista de Maurice, que relata sus sentimientos y preocupaciones: la verdad se le hace insoportable porque cree que lo han enterrado vivo. Grita en vano, se agota, se arrastra por el suelo de la habitación, le falta la respiración. Al calmarse, recupera la razón sólo para darse cuenta del tipo de habitación en que se haya recluido:

He tumbled into half the truth:

Burial alive. His breath was shouting:

'Let, let me out.' But words were puny.

Fists hushed on a wall of inward-outness.

Knees crept along floor that stirred

As softly. All was the same chill.

He knew the wall was circular

And air was catchcry in the stillness

For reason has returned to tell him

That he was in a padded cell. (VI. 21-30) 
Dardis Clarke, como dijimos más arriba, autorizó la publicación de una parte del relato en prosa que escribió Clarke después de dejar el hospital. A pesar de su longitud, queremos incluirla aquí no solo porque demuestra que cuarenta y siete años más tarde Austin Clarke recurrió a ella para componer su poema, sino también porque revela el estado de terror y de agonía en el que se encontraba. Si lo comparamos con la estrofa anterior, vemos que el parecido es asombroso. La versión poética parece ser simplemente una condensación del texto en prosa:

Cyclops seized me, white gleam of beds, of strange faces passed. I was flung into darkness and I heard the sound of heavy bolts. I lay on the cold ground for an endless period too terrified to move, aware only of my breathing. At last I groped around feeling with my hands a circular wall. There was no opening. I was suffocating. I would choke. I called aloud, imploring, but my voice was a whisper. I beat the walls and my knuckles pained, but there was only a dull sound. I rushed around like an animal frenzied, suffocating. Nothing but silence. Exhausted I lay there and as I scratched at what seemed the floor a terrible intuition filled me. I was in a padded cell. (McCormack, In the Prison 74-75)

A través de la interpretación de los sueños y visiones del poema, el lector ha logrado averiguar cuáles eran las causas del derrumbamiento psíquico de Maurice. Estamos ante un excelente caso de ironía dramática, en el que el lector sabe más sobre el protagonista del poema que él mismo. El silencio, la oscuridad, el horror de una celda acolchada que semeja una tumba, y la soledad que invade la habitación llevan a Maurice a que, al menos temporalmente, recobre el sentido - "shocked back / to sanity" (VI. 34-35) - y por fin descubra cuál es la principal razón de su locura: 
Margaret came in a frail night-dress,

Feet bare, her heavy plaits let down

Between her knees, his pale protectress.

Nightly restraint, unwanted semen

Had ended their romantic dream. ${ }^{23}$ (VI. 36-40)

Ahora no se trata de alucinaciones o sueños: Maurice se enfrenta a su propia realidad, y tendrá que resolver el conflicto que su dramática experiencia con Margaret le ha ocasionado. Al final de la sección, Maurice llega al fondo de su propia degradación, al darse cuenta de su propia incontinencia:

Early next morning, he awakened,

Saw only greyness shining down

From a skylight on the grey walls

Of leather, knew, in anguish, his bowels

Had opened. He turned, shivering, all shent ${ }^{24}$. (VI. 41-45)

Esta última estrofa funciona como transición entre la sección VI y la VII, en que se describen las humillaciones que sufre Maurice en su débil estado, y que le llevan a desear la muerte como último recurso para ahorrarse los sufrimientos que le atormentan. En la primera estrofa contempla la idea de suicidarse. Tanto la razón como la religión son potros de tortura que agrandan su vacío interior. La tortura mental está controlada por medio de sedantes: "Beyond the rack of thought, he passed

\footnotetext{
${ }^{3}$ Esta visión la relata Clarke en A Penny in the Clouds: "Suddenly, in a dream, I saw Margaret in her night-dress once more, pale faced, her long black tresses let down beyond her waist. I clasped her so passionately, my mouth on hers, that I woke up in a feverish desire" (47-48). Hay que añadir que al día siguiente le pidió el matrimonio a Margaret.

24 "Shent" es el participio del verbo "To shend" que significa "avergonzar". También tiene un significado arcaico: "perdido", "arruinado". Sin embargo, se puede detectar una mezcla entre "went" y el verbo "To shit” (Maxton 251).
} 
/ From sleep to sleep" (VII. 1-2); de la religión no obtiene ninguna satisfacción porque le falta la fe, "Religion could not cast / Its multitudinous torn cloak / about him" (VII. 3-5). Piensa en suicidarse - "He gave up, tried to cease / Himself" (VII. 7-8) - pero su fe en la vida y en él mismo le van devolviendo gota a gota las ganas de vivir. Para Schirmer,

The shocking equation between religion and suicide that this stanza sets up reflects Clarke's view that both are forms of escape, requiring a surrender of man's reason and self-worth. (PAC 108)

Sin embargo, Clarke está cada vez más débil. Rechaza la comida y obliga a sus cuidadores a forzar su alimentación mediante un tubo que intentan introducirle en la boca-"a tube forced halfway down / His throat" (VII. 17-18) - pero que su cuerpo rechaza con violencia:

Choking, he saw a sudden rill

Dazzling as baby-seed. It spilled

In air. Annoyed, the Doctor drew

Back, glucosed milk upon his shoulder

And overall. (VII. 19-23)

El conflicto se centra ahora entre la voluntad de vivir y la de morir. Según Maxton ${ }^{25}$, el rechazo de la comida lo convierte en cierto modo en un huelguista de hambre, símbolo de desafío hacia médicos y enfermeros, y hacia la autoridad en general.

\footnotetext{
${ }^{25}$ Maxton menciona varios casos de huelga de hambre: James Connolly y Thomas Ashe. Cercano a la fecha de composición del poema se encuentra el alcalde de Cork, Terence MacSwiney, que murió después de 74 días de huelga de hambre el 20 de Octubre de 1920 (251). Una de las huelgas de hambre más resonada fue la que protagonizó en marzo de 1981 Bobby Sands y otros republicanos encarcelados en la prisión de Long Kesh.
} 
Maurice sigue debilitándose, y yace inconsciente en lo que para él es una cámara de tortura. Cuando despierta, el dolor ha cesado, pero en seguida ve al Doctor Leeper avalanzándose sobre él - "For Dr. Leeper sprang, incensed, / At him with many hands" (32-33) - y observa cómo intentan forzar la alimentación de otro paciente. El terror ha desaparecido, y todo lo que le rodea es una sensación de vacuidad y de incomprensión en medio de una tormenta que ilumina su habitación y que le ayuda a pronunciar la palabra que le libera de la sala donde se encuentra y le conduce a su dormitorio: "Claustrophobia".

La tormenta con que termina la sección anterior sirve de transición para la sección octava, que ya había aparecido como un poema independiente con el título de "Summer Lighting" en el poemario Night and Morning:

The heavens opened. With a scream

The blackman at his night-prayers

Had disappeared in blasphemy

And iron beds were bared;

Day was unshuttered again,

The elements had lied,

Ashing the faces of madmen

Until God's likeness died. (VIII. 1-8)

La estrofa muestra una dureza extrema al negar a los pacientes el auxilio religioso. Un paciente vestido de negro que está rezando desaparece blasfemando; los demás se quedan sin los 'elementos', es decir, sin el sacramento de la comunión y, por tanto, sin la gracia divina. La luz de un relámpago ilumina la sala y muestra una escena en la 
que la imagen y semejanza de Dios se les ha negado también, con lo que quedan asimismo excluidos de la religión.

Los relámpagos de la tormenta iluminan el estado de algunos de los internos de la sala. Maurice observa a cuatro de ellos y describe con claridad sus percepciones distorsionadas. Éstos pacientes se pueden dividir en dos tipos: los que sufren de delirios de grandeza y adoptan nombres como Napoleon y Lord Mitchell, y aquellos que pasan por su propio nombre como Christopher O'Brian y James Dunn. Napoleon confunde la brillantez de la habitación donde se encuentra con un espejo; Lord Mitchel cae al suelo dividido en mitades; Christopher no ve más que celdas en su cabeza, y James Dunn confunde su cama con la tienda de la esquina. La claridad con que manifiestan su esquizofrenia es la misma que los aísla y excluye del mundo exterior.

La última estrofa de la sección reafirma el estado de pérdida espiritual de aquellos a los que les ha fallado la razón:

When sleep has shot the bolt and bar,

And reason fails at midnight,

Dreading that every thought at last

Must stand in our own light

Forever, sinning without end:

$\mathrm{O}$ pity in their pride

And agony of wrong, the men

In whom God's image died. (VIII. 33-40)

El hombre está hecho a imagen y semejanza de Dios, pero la imagen se desvanece al perder la razón. Según Martin, "Thought" significa principalmente "bad thoughts", 
haciendo clara referencia al pecado de Onán: "God's image is thus - ‘sinning without end' - endlessly destroyed in the insomniac's obsessive fantasies" ("Technique" 102).

El temor a la muerte que ha dominado la conciencia de Maurice en la mayoría de las secciones anteriores abre la novena sección del poema: "Timor Mortis was beside him" (IX. 1). Sin olvidarse de este temor, Maurice observa a Mr. Prunty ${ }^{26}$, un respetable hombre de pelo cano, y de baja estatura. Clarke, en dos estrofas, traslada al lector a los márgenes de la conciencia humana, y le muestra un mundo donde la mente rechaza el materialismo del cuerpo y donde la imagen de Dios se ha desvanecido. La presencia de Swift se palpa en las siguientes estrofas:

Poor Mr. Prunty had one fault

In bed. Nightly he defecated.

Warder, great-handed, unbolted his vault,

Swept sheet and blanket off in a rage

At 'Murder! Murder!' dragged the body

Naked along the corridor.

Trembling beneath the piled-up bedclothes,

Maurice could hear bath-water pouring.

Far doors were opening, closing

Again. The corpse was clumping back.

The warder stuck it on the close-tool,

Laid out clean pair of sheets and blanket.

Soon Maurice waited for his turn,

Whenever he wet the bed; sodden

\footnotetext{
${ }^{26}$ Según Maxton (252), 'Prunty' es "an unusual and distinctive name, [that] was borne by the family of the Brontë's sisters before their father's migration from Ireland.
} 
Sheets pulled off. The warder called him 'Dogsbody',

Christened his ankles with the key-bunch. (IX.9-24)

Como vimos en el capítulo $\mathrm{V}$ dedicado a la sátira, Clarke utiliza una técnica reduccionista para degradar la condición humana y reducirla a su naturaleza más básica. Una de sus funciones es la de recordar al hombre sus limitaciones y debilidades, las cuales se manifiestan en situaciones en las que éste se siente impotente. En Mnemosyne Lay in Dust, tanto Maurice como el resto de los internos sufren la degradación del sistema psiquiátrico, que expone su intimidad, degradando así toda posible pretensión humana. Las estrofas de Clarke muestran un mundo donde palabras como "spew", "shent", "prick", "spill", "shriek", "drag” y "pissed" rebajan la dignidad humana al mostrar acciones o actos que no pertenecen a la realidad cotidiana de la conciencia. Maurice y los pacientes del hospital se hallan en un estado en el que su propia conciencia está más cerca de la periferia del mundo que la de aquellos que están fuera del hospital. En las estrofas anteriores, el léxico utilizado para mostrar el tratamiento de Mr. Prunty y de Maurice es revelador: "defecated", "unbolted his vault", "dragged the body", "naked", "corpse", "set the bed", "sodden sheets", "Dosgbody". El paciente es tratado con violencia y desconsideración, como si fuera de por sí un cadáver a quien se le saca de una tumba - 'vault' - y se le arrastra desnudo por el suelo. Para Brown, "the reader is left with a chastened sense of the fragility of awareness, of the way consciousness itself can be set at nought and reason brought low" ("Satirist" 139). 
Maurice observa con miedo las vejaciones que recibe Mr. Prunty y teme que él, debido a su incontinencia, reciba un trato similar. El clímax de la degradación llega cuando el enfermero que está de guardia lo "bautiza" con el ofensivo nombre de "Dogsbody", golpeándolo en los pies con un manojo de llaves. De esta manera, Clarke satiriza el sacramento del bautismo por partida doble: primero con una clara referencia al símbolo papal de las llaves, y segundo empleando un nombre ofensivo. Quizás, el encontrarse en lo más profundo de la degradación física hace que Maurice conecte con la realidad. Es consciente de los ruidos de la ciudad, de la charla de los enfermeros, del crujido del periódico, y de las últimas noticias: el fallido vuelo de Hawker ${ }^{27}$ sobre el Atlántico. Tranquilo y atento a lo que ocurre en su entorno, Maurice escucha la conversación de los enfermeros mientras se va quedando dormido:

Often he heard them repeating a tale

Of the Gate, the Garden and the Fountain:

Three words that lulled him as he fell

Asleep: Mesopotamian sound

Of a claustral stream that stelled him.

The words became mysterious

With balsam, fragrance, banyan trees,

Forgetting the ancient law of tears,

He dreamed in the desert, a league from Eden.

How could he pass the Gate, the sworded

\footnotetext{
${ }^{27}$ Este es uno de los pocos sucesos que aparecen en el poema que se pueden fechar con exactitud. Los días 18 y 19 de Mayo de 1919, Harry George 'Hawker' (18889 - 1921) y Kenneth Mackenzie-Grive no pudieron cruzar el Atlántico en avión al tener que amerizar cerca de un barco danés por problemas técnicos (Maxton 252).
} 
Seraphim, find the primal Garden,

The Fountain? He had but three words

And all the summer maze was guarded. (IX. 36-48)

En estos versos aparecen imágenes que es preciso considerar. Para Maxton, el Jardín, la Puerta y la Fuente "are not necessarily to be identified with the environs of the hospital" (252), aunque nosotros creemos que sí hay una asociación directa con el hospital porque estas imágenes vuelven a aparecer en las secciones XIII y XVIII: "The legendary Fountain turns out to be the one by the horse-trough at the top of Steeven's Lane, the Gate and Garden those of the hospital itself" (Martin, "Technique" 103). Hay que tener en cuenta que estas tres palabras se las oye Maurice a los enfermeros, que probablemente sí se refieren al hospital. No obstante, esto no es óbice para que puedan hacerse otras interpretaciones. Sabemos que Maurice está física y espiritualmente desahuciado, y estas palabras crean un efecto reparador en su mente, porque para recuperar la gracia espiritual ha de encontrar el Jardín del Edén que, aparte de su inevitable asociación bíblica ${ }^{28}$, se puede también identificar como el jardín de la memoria ( $c f$. Harmon, $A C$ 216), interpretación que podemos ampliar algo más. Maurice ha perdido la memoria debido a los efectos que la estricta moral religiosa tuvieron en él, y así como Adán y Eva fueron expulsados del Paraíso por haber pecado, de la misma manera Maurice - pecador contra la Iglesia Católica al rechazar sus dogmas de fe- ha sido arrojado a un hospital psiquiátrico - un "Hades" figurativo-, y ahora ha de hacer las paces con su conciencia y volver al Paraíso 
donde recuperará la memoria. Este jardín simboliza su liberación del hospital, y para ello tiene que resolver el conflicto que le atormenta. La Puerta, el Jardín y la Fuente, además de referirse al jardín del Edén, representan para Maurice el futuro que le aguarda al otro lado de las paredes del hospital.

En esta sección novena, las percepciones de Maurice son más racionales. Observa a un enfermero que se pasa la noche recostado en una silla leyendo una novela, y lo asocia con la Razón, porque en definitiva son los enfermeros, los guardianes del hospital, quienes tienen la llave de su liberación:

All through the night the warder sat,

Chair tilted back, beside the fire;

Reason, the master of ancient madness. (IX. 49-51)

De las imágenes tormentosas que mostraban figurativamente el estado de desconexión mental de los pacientes en la Sección VIII, y de los momentos de lucidez y calma de la sección anterior, pasamos a la Sección X, que comienza igualmente con imágenes de serenidad y calma. Según Maxton, las imágenes parecen provenir de un cuadro en la pared (253): en él, ajenos a los sucesos ${ }^{29}$ que ocurren en ese momento en el mundo, unos soldados descansan por la noche junto al fuego después de haber sido derrotados.

\footnotetext{
${ }^{\ngtr}$ En el libro del Génesis, el Edén estaba guardado por "los querubines y la espada de llama flamante para guardar el camino del árbol de la vida" (Gen. 3,24$)$. A su vez, había un río que regaba el jardín y que se dividía en cuatro (Gen. 2, 10).

${ }^{29}$ Los sucesos que menciona Clarke en el poema acontecieron en 1918, "General Election, the ending of the Great War", y en Dublín, "the Catholic diocese is centred on a 'Pro-Cathedral' (St Mary's, Marlborough St, 1815) because the Church (officially) maintained that the pre-Reformation cathedrals should not be held by the Church of Ireland" (Maxton 253).
} 
In Winter around the fire,

Soldiers at a camp

After the long rout. (X.1-3)

Recordemos que en uno de los sueños que vimos en la Sección V, Maurice se veía como un soldado republicano en el condado de Limerick durante la Guerra de la Independencia, que se libró precisamente durante el tiempo que Clarke pasó en el hospital. Así, no es de extrañar que las imágenes con que empieza el poema sirvan de conexión entre la realidad al otro lado de los muros del hospital y la irrealidad en la que vivía Maurice.

They lie, in the dark,

Watching the fire, on the edge

Of a storybook jungle: they watch

The high boots of the colonists. (X. 16-19)

El pronombre personal "they" presenta cierta ambigüedad, y no le da al lector la oportunidad de saber si se refiere a los soldados que aparecían en la primera estrofa de esta sección, o a los propios internos del hospital imaginándose como los soldados aterrorizados por las fuerzas coloniales. En cierto modo, ellos, los pacientes, están internados a merced de un poder que no pueden controlar:

In that imagining, they offer a political understanding of their own plight: which is, that to be dominated by such forces, and to suffer the consequences of the oppositional subversion and terrorism to which they inevitably give rise, is itself a kind of socio-culture insanity. (Corcoran, AYJ 114) 
Pero para la frágil mente de Maurice, los soldados representan la libertad, porque no los aflige ninguna crisis espiritual o moral, como a él, y no tienen que aguantar tormentos de culpabilidad. Son libres porque "Justice cannot reach them" (X. 21), al no existir ésta: "The scales are broken" (X. 20). Además, Maurice no tiene memoria, por lo que,

All the uproar of the senses, All the torment of conscience, All that twists and breaks. (X. 22-24)

no tiene sentido "Without memory or insight" (25). Para él se hacen realidad las palabras del dicho "out of sight, out of mind". El olvido o la falta de memoria conduce, si no a la felicidad, sí a la tranquilidad que se siente al no recibir información de los sentidos, porque sin memoria, "The soul is out of sight" (X. 26):

And all things out of sight

And being half gone they are happy. (X. 27-28)

Freud comenta que los pacientes atormentados por sufrimientos físicos o morales suelen soñar o imaginar lo que la realidad les niega: bienestar y dicha. Los delirios de Maurice están constituidos, como hemos visto, por una imaginada realización de deseos, "cuya pérdida, ausencia o negación en la realidad nos da la razón psíquica de la locura" (403). Maurice mira el cuadro de la pared y su mente asocia las imágenes en él con deseos incumplidos y que, paradójicamente, le confieren 
cierta lucidez y lo llenan de calma; no obstante, Maurice sigue sufriendo alucinaciones, que demuestran que no está todavía recuperado:

On a sun-free day, his senses lied, for

They showed him a man that had been killed.

His severed head lay on the pillow

Beside him, grey-bearded, with lidded eyes.

No axe ... no blood. How did it happen?

He looked again. Slim palms had placed it

Near the window: hallucinatory

Head of an aged John the Baptist. (X. 34-41)

Estas alucinaciones cobran de nuevo sentido en palabras de Freud: "La calvicie, el cortarse el pelo, la extracción o caída de una muela y la decapitación son utilizadas para representar simbólicamente la castración" (562). El origen de estas extrañas imágenes puede estar en el celibato que Margaret impuso a Clarke / Maurice, y que podemos interpretar como una castración psicologica ${ }^{30}$, que en el poema viene simbolizada por la decapitación de Juan el Bautista ordenada por una mujer, Salomé, que simboliza a Margaret. Recordemos que la ausencia de relaciones sexuales es la causa principal por la que Maurice se encuentra internado, y no es de extrañar que le produzca toda clase de alucinaciones oníricas.

Las siguientes estrofas siguen mostrando extraños sucesos que llevan a Maurice a su niñez - "Soon Mnemosyne made him smaller, / A child of seven" (X. 42-43). Ve a su madre sentada a la máquina de coser y observa tranquilas escenas domésticas que

\footnotetext{
${ }^{30}$ Esta idea proviene de "the celibacy of Catholic priests is a 'substitute for castration'", citada en Paglia. 44.
} 
se ven interrumpidas por maníacos saltando y gritando "Murder!", que aterrorizan al pequeño Maurice que se despierta temblando:

There on his bed, a terrible Twangman ${ }^{31}$

Was sitting. He muttered 'Hang him! Hang him!'

As he nodded, twiddling paper spills. (X. 55-57)

Después de este sueño de terror, Maurice se ve corriendo por los callejones de Dublín, explorando la ciudad fuera del hospital. Se para en cada esquina y solo encuentra el eco, con quien sigue su vagabundeo por la ciudad. Para Harmon, "These disturbing undercurrents of fear and guilt intrude upon the general calm of section X" (AC 217). Este caminar solitario por la ciudad le lleva a una alegórica representación de onanismo, que le sirve a Maurice de consolación, aunque ésta es furtiva, vergonzosa y se encuentra asociada con la locura:

Often in a priestly robe on a

Night of full moon, out of the waste,

A solitary figure, self-wasted,

Stole from the encampments - Onan,

Consoler of the young, the timid,

The captive. Administering, he passed down,

The ward. Balsam was in his hand.

The self-sufficer, the anonym. (X. 66.73)

Esta solitaria figura que aparece una noche de luna llena es misteriosa: se presenta vestida de sacerdote, administrando el "bálsamo" de la masturbación. Recordemos que el sueño es también la realización de un recuerdo, por lo que la causa de estas

\footnotetext{
${ }^{31}$ Según Maxton, "In Dublin song and legend the 'Twangman' was a fearsome figure" (253).
} 
imaginaciones pueden estar en el interrogatorio al que le sometió un sacerdote en el confesonario y que ya hemos visto anteriormente. Esta idea la confirma también Corcoran al apuntar que

It is perhaps not necessary to have read Clarke's account, in Twice Round the Black Church, of an appalling childhood confession in which he was forced to 'confess', in terror, to a 'sin' which he had hardly imagined, let alone committed, to realise that Onan's priestly garb is an ironic comment on the sexual fixation and obsessions of Irish clericalism. ("Blessing" 46-47)

El sueño de Maurice, no obstante su displicencia, abriga el deseo de una satisfacción reprimida. Para Freud éste sería un caso de deformación onírica y deduce que

si [los sueños] se muestran deformados y aparece en ellos disfrazada la realización de deseos hasta resultar irreconocible, es precisamente porque existe una repugnancia o una intención represora orientadas contra el tema del sueño o contra el deseo que de él emana. (445)

Está claro que el deseo de Maurice en éste, como en los demás sueños, es la consecución de relaciones sexuales satisfactorias, y la intención represora es tanto el código moral que le fue inculcado como las reprobatorias palabras del sacerdotes en la confesión. De este modo, Onán ${ }^{32}$, vestido de sacerdote, representa por un lado la reprobación de la masturbación que Maurice sufrió en su infancia y, por otro, la realización de sus deseos. Si recordamos la sección VI del poema, en la penúltima estrofa recordaba su relación con Margaret y decía, "Nightly restraint, unwanted

\footnotetext{
${ }^{32}$ Recordemos que Dios no aprobó el comportamiento sexual de Onán, al no querer fecundar a su cuñada, y fue castigado con la muerte (Gén. 38, 4-10).
} 
semen / Had ended their romantic dream" (39-40), por lo que es fácil deducir que sus sueños están producidos por la insatisfacción de su subconsciente. El estado mental de Maurice lo sugiere la última palabra de la estrofa, 'the anonym', que enfatiza la destrucción de todo vestigio de su identidad.

Onán no es importante sólo en un contexto moral y teológico, sino también en uno político, ya que ofrece consuelo a la violencia política de la época. En la estrofa, Onán sale de unos campamentos militares, que pueden representar dentro de la trastornada imaginación de Maurice el propio hospital donde se encuentra. Los cuidadores serían los soldados del batallon que "lie, in the dark, / Watching the fire" (X. 16-17). La aparición de Onán en el poema aglutina lo religioso, lo político y lo sexual como piedras angulares de la enfermedad de Maurice. La ausencia de personalidad del poeta queda sustituida con

The presence of the conditioning circumstances which have provoked and produced that absence: the impossibility of a true sexual relation; the anxiety induced by a false, neurotic religion; the terror of living through a period of violent political upheaval. (Corcoran, "Blessing" 47-48)

En las siguientes secciones empieza la recuperación de Maurice. En la sección XI Maurice rompe su ayuno y empieza a comer de forma voluntaria:

In June, upon the little table

Between the beds, he saw a dish

Of strawberries. As they lay

There, so ripe, ruddy, delicious,

For an hour he played with his delay

Then in delight 
Put out two fingers towards the wished-for,

Ate for the first time. (XI. 9-16)

El plato de fresas que le había enviado su madre recuerdan inmedi atamente al famoso poema de William Carlos Williams, "This is Just to Say", en el que se describen unas ciruelas de forma exuberante ("they were so delicious / so sweet / and so cold"), con la diferencia de que el narrador del poema de Williams se come las ciruelas sin pensárselo dos veces, mientras que Clarke se come sus fresas después de una larga espera, como si necesitara un precalentamiento. La Sección $\mathrm{XII}^{33}$, compuesta únicamente por un estrofa, es particularmente significativa porque en ella vemos la recuperación física de Maurice, que le conducirá más tarde a su recuperación mental. Estamos en verano y la estación parece afectarle a él de la misma forma que afecta al mundo natural, es decir, parece despertarlo del letargo en que ha estado sumido:

Nature,

Remembering a young believer

And knowing his weakness

Could never stand to reason

Gave him from the lovely hand

Of his despairing mother,

A dish of strawberries

To tempt

And humble the fast

That had laid him nearer than they were

Along her clay. (XII)

${ }^{33}$ Esta sección había aparecido en el poemario Flight to Africa and Other Poems (1963), con el nombre de "Fragaria". 
La naturaleza funciona oponiéndose a la religión de Maurice, y es ella la que, a través del plato de fresas que le envía su madre, le devuelve a la vida. La función de estas líneas es demostrar la futilidad de la religión en que ha crecido Maurice y que le ha llevado a la locura, privándolo de la razón y acercándolo a la muerte. Al recibir las fresas, "Nature helps Maurice overcome his fast from life, the tendency toward selfdenial that is a product of his religious heritage" (Schirmer, PAC 110). Su ayuno le había colocado cerca de la muerte. Tapping confirma el doble significado de "Nature". Por un lado es una madre que da vida - las fresas; por otro, es una metonimia de su madre muerta que se halla ahora en la tierra donde crecieron las fresas:

The same clay that holds his mother's remain - and which might also have become Maurice's grave- gives life to the strawberries and ultimately to Maurice himself. (Tapping, $A C$ 268)

Como hemos visto, la causa principal, si no la única, del conflicto de Clarke tiene sus raíces en la religión católica. Indirectamente, ésta le ha confinado en un hospital psiquiátrico donde el conflicto mental que le causó se ha materializado a través de sueños, miedos y pesadillas. El incidente de la comida marca un punto crucial en la recuperación de Maurice: su percepción de la realidad ha dejado de ser una tortura. Una vez recuperado físicamente, le queda ahora acometer la tarea de recuperarse mentalmente.

Poco a poco se va dando cuenta de la realidad fuera del hospital. Escucha las voces más allá de la puerta que lo separa del mundo exterior y vuelve a pensar en el Jardín, la Puerta y la Fuente que, al contrario que en la sección IX, son ahora 
referencias exactas e indican que es consciente de lo que ocurre a su alrededor. Maurice empieza a considerar su situación de forma racional, y se plantea por qué está encerrado entre cuatro paredes:

... Unwieldy

He wondered why he had been straight-laced,

Straight-jacketed

But soon he suture would unseam,

His soul be rapt. (XIII. 12-16)

La metáfora, "suture would unseam" expresa la pronta liberación de Maurice de la camisa de fuerza, aunque no todavía del hospital. La última línea de la estrofa es la promesa que refuerza esa liberación.

La Sección XIV sigue describiendo su lenta pero continua recuperación, y empieza mostrando a Maurice junto con otros pacientes. Es la primera vez que se le permite moverse con libertad, aunque la ropa que lleva sigue controlando sus movimientos: "Thickly clad like an imbecile, / No buttons to open in front - safe wear-“ (XIV. 9-10). En el patio del hospital, se junta con otros dos internos y dan vueltas alrededor del patio para hacer ejercicio, pero es Maurice quien se diferencia de los otros dos. Aunque se da cuenta de su enfermedad al verse a sí mismo como otro interno, su habilidad para reírse es un síntoma de su recuperación: “...Maurice laughed / To find he was an imbecile, / The quickest of them and the daftest" (XIV. 33-35).

A medida que va recobrando la lucidez y la memoria, Maurice se siente diferente y alejado del resto de los pacientes del hospital. Así, en la sección XV, 
tenemos una rápida pero detallada descripción de, al menos, diecisiete internos. Las descripciones están más cerca de la crueldad que de la compasión, y en casi todas aparece el defecto o vicio que caracteriza al paciente en cuestión. Las estrofas de esta sección tienen un marcado tinte satírico. Clarke expone los hechos marginales y periféricos de la conciencia humana que, de una forma u otra, degradan la conducta humana, y describe a los pacientes del hospital - en realidad sus compañeros de hospital - en términos del elemento principal que define la psicología y patología de los pacientes. Así, tenemos a Mister Radcliffe que aúlla cuando se le pega o se le ridiculiza. Maurice observa su deformidad física:

Mahoganey skulled, molarless, with two paws, Spoonfed on pap. When he was teased or slapped.

He howled: 'Holy St. Francis, stawp it, stawp it.' (XV. 2-4)

Algunos pacientes muestran problemas relacionadas con el sexo. Bobby Walpole es un loco compulsivo que se pega cabezazos con las paredes y acostumbra a orinar a través de la rejilla de la chimenea y a vociferar desde el patio; Lord Mitchell se lava sus partes pudendas ante la mirada puritana de uno de los enfermeros: "Look at / The dirty fellow washing his cock!" (XV. 34-35). La violencia hace acto de presencia en Tom Dunphy, "He would rage, / Calling down curses on the hellish pack" (XV. 14 15); en Mr. McLoughlin, con antecedentes homicidas y con quien Maurice hablaba en francés; y en el grandote contratista Mr. Cooper "Who raged around himself until he was padded" (XV. 67). La depresión mina la fortaleza de Sandow A. Jackson que "often he was downcast" (XV. 27). Mr. Crosthwaite, en cambio, no es consciente de 
las más mínimas normas de conducta y "His tongue sprang up / To lick the dribble from his nose" (XV. 20-21). Aparte de las acciones que identifican a los pacientes, la elección del vocabulario es crucial a la hora de rebajar la condición humana de los enfermos: "Mahohaney skulled", "molarless", "paws", "pissed", “yard", 'cock', "dribble". Para Brown, estas palabras, "in their unremitting reductionism insist on the undeniable physicality of existence in a way which undermines human pretension" ("Satirist" 139).

Los primeros vestigios de la curación de Maurice surgen en la Sección XVI, y se manifiesta en las respuestas a las preguntas que el doctor Rutherford le hace: “"Do you believe in God?' / He answered 'Yes'” (XVI. 4-5). A la pregunta de si su tío es una persona adinerada, Maurice no dice la verdad: “'Is he well-to-do? ... Quickly, he lied"” (XVI. 22-24). Según Harmon, la capacidad de Maurice para saber cuando ha de mentir es un síntoma de su recuperación ( $A C$ 218). Pero todavía no está completamente curado, y él mismo se ve incapaz de leer un libro que encuentra en la biblioteca del hospital:

One afternoon he opened the bookcase

Found The Black Monk and Other Stories

By Anton Chekov. Nothing could hold his

Attention. The words had changed to pothooks,

Hangers. Words hid their meaning from him. (XVI. 25-32)

Lo que sí va a confirmar su curación será el paseo que da por el parque Phoenix con uno de los enfermeros del hospital, y donde es consciente de la realidad que lo rodea: 
recuerda donde vive su familia, reconoce gente con la que se encuentra, observa lugares conocidos:

Summer was sauntering by,

Beyond the city spires,

As Maurice went a-walking

With Mr. Rhys by white-and-

Blue trams and jaunting cars, (XVII. 1-5)

His family lived there.

Thinking of them, he sighed (XVII. 19-20)

He saw Columba O'Carroll

Who smiled as he raised his hat

Behind invisible bars. (XVII. 33-35)

La última línea es significativa porque Maurice sigue encerrado en el hospital - no ha sido oficialmente dado de alta - y tiene que volver a su oscura prisión:

...Up Steeven's Lane,

He walked into his darkness.

Classical rustle of Harpies,

Theirs ordure at Swift's Gate. (XVII. 55-58)

Estas líneas nos remiten a la primera sección del poema en la que Maurice fue llevado al hospital en taxi. Su estado mental es completamente distinto. Las arpías son descritas desde una distancia que no aparecía en la Sección I. Entonces, las imágenes eran de terror, oscuridad, y encarcelamiento. Literalmente se dirigía hacia la muerte, hacia un enterramiento en vida, a un submundo dantesco donde perdería la memoria y la creatividad, y la memoria sería mancillada por las arpías que habitaban en él: la 
guerra que resolvería el conflicto dentro de su mente acababa de estallar. Ahora, casi un año y medio después, Maurice ha purgado sus miedos y tormentos, ha salido victorioso de un conflicto que lo sumió en las tinieblas de la mente, y, cual ave Fénix, sale del hospital como si hubiera renacido de las cenizas de la frustración y del terror:

Rememorised, Maurice Devane

Went out, his future in every vein

The Gate had opened. Down Steeven's Lane

The high wall of the Garden, to right

Of him, the Fountain with a horse-trough,

Illusions had become a story. (XVIII. 1-6)

Un año después de la publicación de este poema, Clarke volvería a recordar su estancia en el hospital de Swift en "A Sermon on Swift" (1968), donde reconocería la ayuda inestimable de la musa de la poesía, hija de Mnemosyne, Erata:

Last gift of an unwilling patriot, Swift willed

To us a mansion of forgetfulness. I lodged

There for a year until Erata led me

Beyond the high-walled garden of Memory,

The Fountain of Hope, to the rewarding Gate.

Reviled but no longer defiled by harpies. (107-112)

La resolución del conflicto en el que se hallaba sumido Clarke / Maurice se ha reducido a una difícil y tortuosa búsqueda de Mnemosyne, como madre, memoria y musa. Maurice se ha visto envuelto en un arquetípico viaje de descenso y de retorno, en una alegoría de muerte y de renacimiento. El poema se abría con imágenes de oscuridad en las que el protagonista del poema fue "procreado" y termina en la casa 
donde su madre nació. Es interesante el movimiento entre "got", feo monosílabo apropiado en el contexto que abre el poema, y "born", con la que se refiere a su madre. Ambas imágenes de procreación marcan la diferencia entre un Maurice mentalmente sano y otro enfermo. Asimismo, las imágenes de oscuridad que abrían el poema se transforman en imágenes luminosas al cerrar el poema:

At Number One in Thomas Street,

Shone in the days of the ballad-sheet,

The house in which his mother was born. (XVIII. 13-15)

Clarke, a través de Maurice Devane, ha revivido casi cincuenta años más tarde el eterno conflicto que hemos encontrado en buena parte de su poesía: el conflicto entre el espíritu y el cuerpo, entre la fe y la razón, entre lo religioso y lo pagano, entre la sociedad, el estado, la Iglesia, las instituciones y el individuo. Mnemosyne Lay in Dust vuelve a mostrar sin rodeos cómo las enseñanzas de una Iglesia conservadora y puritana pueden dañar la conciencia del individuo y cómo una institución psiquiátrica puede degradar la condición humana hasta el extremo de anular toda identidad.

Mnemosyne Lay in Dust expone las terribles prácticas psiquiátricas y médicas de los hospitales de Dublín hacia 1919, y las sitúa en un contexto histórico de rebelión política contra el poder colonial. El poema mezcla lo político, lo psíquico y lo sexual. Como expresa excelentemente Corcoran,

Mnemosyne Lay in Dust writes a Dublin of the individual human body and mind: it identifies a private nightmare as a catastrophic public history. In this was it gives a new resonance to Stephen Dedalus's sense 
of history as "a nightmare from which I am trying to awake". (AYAJ 114).

El poema representa el drama psicológico que produce una religión cuyo poder, respaldado por una política del miedo, se centra en inculcar un sentimiento de culpabilidad en la conciencia del individuo. 
CONCLUSIONES 
Ha llegado el momento de hacer escala, pero no de mirar atrás, sino hacia delante - acaso una rápida mirada de reojo para tomar nota de dónde se hallaban Escila y Caribdis, las sirenas, y los escollos errantes para sortearlos de aquí en adelante. Aquél viaje que emprendí casi trescientas y pico páginas atrás ha completado una primera etapa, pero, por supuesto, no ha terminado, porque cuando uno se embarca en la aventura investigadora, "Itaka" no se alcanza nunca: se completan etapas, se hacen diversas escalas, se conoce a numerosos viajeros más o menos interesantes. La soñada isla no ha de alcanzarse jamás. Si así fuera, el viaje habría concluido, y yo no me enrolé para quedarme varado en tierra yerma mucho tiempo.

Como decíamos en la Introducción, la idea de conflicto ha vertebrado la historia de Irlanda desde tiempo inmemorial. En las páginas literarias del país también hemos observado cómo el conflicto se destila entre ellas y cómo la mayoría de sus autores han estado marcados por algún tipo de conflicto, ya haya sido éste privado, público o ambos. Después de un breve periodo sumergidos en el piélago literario irlandés, emergimos con un autor que nos llamó la atención, un autor que parecía representativo de la conflictiva relación entre el escritor e Irlanda.

Austin Clarke es una figura transitoria en la poesía del siglo XX: un poeta que une la tradición gaélica del siglo XVIII con el legado literario que dejaron Yeats y Joyce. La última década del siglo XVIII vio el derrumbamiento del mundo gaélico. Recordemos que el mundo poético gaélico se vio afectado al venirse abajo el tradicional patronazgo de la nobleza gaélica, ya que los poetas se encontraron 
sin nadie que los protegiera y nadie a quien dirigir sus voces poéticas. La inmensa mayoría católica era iletrada, mientras que los escritores protestantes, desde Sheridan y Goldsmith hasta Swift se dirigían a una clase mucho más culta. La luminosa poesía de autores como Aogán Ó Rathaille o Eoghan Rua 6 Suilleabháin y la abundante y anónima poesía "folk" dieron paso a un siglo XIX oscuro, no solo desde el punto de vista literario, sino también desde el histórico. Fue un periodo dominado por conflictos sociales, políticos, y religiosos, y, sobre todo, por la Gran Hambruna de mediados de siglo, que diezmó la población irlandesa dejando un panorama estéril y desolado. El idioma gaélico estaba poco menos que extinguido a comienzos de 1800 , y no sería hasta aproximadamente 1875 cuando se empezó a tomar en serio. Como hemos visto, Clarke recoge el legado de Yeats y Joyce y lo funde con la tradición gaélica, y esta mezcla literaria sería a su vez germen para poetas de generaciones posteriores a la de Clarke.

En sus poemas, nuestro escritor nos ha relatado, unas veces en primera persona, otras en tercera, su particular visión del individuo, la sociedad y las instituciones de su país. Después de analizar sus poemas, a la luz de su biografía y de la historia de Irlanda, hemos llegado a las siguientes conclusiones. Primera, el conflicto que presenta Clarke en su poesía evoluciona desde un plano privado hasta uno público a medida que se va liberando de sus propios problemas de conciencia: la frustración que le cré la obligatoria observación del sexto mandamiento, la crisis de fe, el celibato impuesto por su primera mujer, las consecuencias de casarse fuera del seno de la Iglesia, y la crisis nerviosa que lo hospitalizó. Segunda, el 
abuso de poder que la Iglesia Católica y las instituciones irlandesas ejercieron -la una desde el púlpito, las otras desde el escaño- y la falta de humanidad que demostraron han sido el denominador común del conflicto clarkeano. Y tercera, los problemas que afligían a Clarke eran a su vez problemas colectivos, que muestran claramente cómo el conflicto forma parte de la realidad irlandesa.

Austin Clarke vivió una vida marcada más por el desencanto que por el triunfo, y en su obra hemos podido ver la huella que dejó la Iglesia Católica en él. El autor siempre tuvo una salud frágil; sin embargo, las profundas depresiones que sufrió, sumadas a un ataque cardíaco, no evitaron que viviera una vida notablemente larga, acompañado por su segunda esposa y sus tres hijos. En el Capítulo I vimos también su relación con los escritores más importantes de Irlanda: Swift, a quien consideró su maestro; Yeats, de cuya sombra nunca pudo deshacerse; Joyce, cuya senda decidió seguir; y Kavanagh, cuya aversión hacia Clarke nunca quedó justificada.

En el Capítulo II, examinamos Pilgrimage and Other Poems, poemario que nos introdujo en la Irlanda Medieval, época que el llamaría Celto-Romanesque. Esta obra es importante por tres razones. La primera, porque representó la deserción de Clarke del romántico mundo mitológico al que había dedicado cuatro poemas épicos. Clarke quería deshacerse de la sombra de Yeats y de las caducas ideas del Resurgimiento Literario Irlandés, especialmente porque se dio cuenta de que la poesía épica no le conducía a ninguna parte: tan sólo estaba repitiendo lo mismo que habían hecho los poetas de la generación anterior a la suya. 
La segunda razón es la de ser el poemario con el que comienza su viaje por los lugares y periodos de la Irlanda Medieval, época que el denominó CeltoRomanesque y que utilizaría como correlato histórico para poner de manifiesto su propio conflicto privado, y comentar con mayor objetividad el papel que la religión jugaba en su propia época.

La tercera razón es la de dar voz a la mujer, a quien Clarke consideraba una víctima del puritanismo de la Iglesia Católica y el Estado en Irlanda. De igual forma que Kavanagh denunció en The Great Hunger la miseria sexual del hombre rural a través de la voz de Maguire, un simple recogedor de patatas de la Irlanda rural, así Clarke, a lo largo de toda su obra, expone la frustración de la mujer irlandesa. Como hemos visto a lo largo de las páginas de esta tesis, solitarias mujeres célibes como Martha Blake, Miss Rosanna Ford, Miss Marnell, y muchas otras mujeres anónimas, se convierten en tristes sinécdoques de la condición en la que se hallaba la mujer en el Estado Moderno Irlandés, y cuya penuria social, sexual y espiritual saldría vehementemente a la luz en los poemas de Clarke. Hemos conocido también mujeres que, a pesar de las restricciones de conciencia que imponen los dogmas de la Iglesia, no han dudado en disfrutar plenamente de su sexualidad.

Aquí, Clarke nos muestra el conflicto entre la propia sexualidad humana y los dogmas religiosos que la restringen y limitan. Recordemos al eremita cuya conciencia estaba constantemente acosada por una mujer que representaba simplemente su propia naturaleza humana; a Gormlai, la princesa que tuvo tres maridos, y que vivió sus últimos días sola y abandonada con su conciencia en un per- 
manente estado de angustia existencial provocada por el remordimiento de haber amado fuera del matrimonio; y a la joven de Beare, cuyo destino siguió derroteros similares a los de Gormlai y el eremita, pero que no dudaba en inclinar los platillos de su balanza moral a favor de su propia sensualidad, al contrario que su antecesora en "The Old Hag of Beare". Además del conflicto entre la carne y el espíritu, hemos analizado los poemas que muestran el conflicto entre la religión católica y el paganismo, primero, y el Protestantismo después.

Los dogmas eclesiásticos no siempre provocaban el mismo tipo de conflicto en el individuo. Los personajes de Pilgrimage se enfrentaban a aquellos dogmas que ponían coto a la libre expresión de su sensualidad. El dilema cambia en la mayoría de los poemas de Night and Morning, donde Clarke expone en primera persona el conflicto que produce el enfrentamiento entre la razón y la fe. En este poemario no encontramos a una mujer con su conciencia dividida, ni a un asceta afligido, ni incluso a un estudiante que se apartaba del "buen" camino y temía las consecuencias, sino a un hombre bajo la amenaza de perder la imaginación y el intelecto, y cuyo miedo a la oscuridad del más allá - "Darkness that man must dread at last" - le lleva a la desesperación. Clarke no se libra totalmente del conflicto que provoca la razón y la fe, pero creemos que sí logra alejarse de él y, a la manera de los escolásticos medievales, alcanzar un equilibrio espiritual.

Pero Night and Morning ofrece también el polo opuesto. Martha Blake es una beata sin problemas de conciencia que encuentra plena satisfacción dentro del seno de la Iglesia Católica. La comunión diaria llena de gozo su alma, al mismo 
tiempo que las necesidades de su cuerpo pasan a un segundo plano. ¡Qué poco sabía entonces Martha lo que veinticinco años después le depararía su obsesiva dedicación a la Iglesia! Con este poema, el poemario alcanza un equilibrio entre el atormentado narrador de la mayoría de los poemas y la beatífica actitud de Martha. Al final, vemos que la religión católica controla la conciencia del individuo incitándolo ya sea a la rebelión, ya al sosiego. Además, este poemario es importante porque contenía la simiente estilística que proliferaría en la segunda etapa poética de nuestro poeta: la sátira.

En 1955, después de diecisiete años sin escribir poesía, Clarke reaparece e inaugura una nueva etapa poética en la que continúa con el tema del conflicto pero trasladado a una esfera pública. Los problemas de conciencia habían quedado diluidos en la lluvia metafórica de "Ancient Lights". A partir de ahora, emprenderá una cruzada personal contra la Iglesia Católica y las instituciones irlandesas. Ya en el poemario anterior habíamos visto "Penal Law" y "Her Voice Could not Be Softer", pequeños anticipos satíricos de lo que vendría después. Clarke pasa revista no sólo a la Iglesia Católica sino también a los gobiernos sucesivos de la Irlanda posterior a 1922, unas veces de forma individual, otras de forma conjunta. Sus ataques a las instituciones los formalizaría a través de la sátira que, aunque no tan poderosa e hiriente como la de Jonathan Swift, sí tenía las mismas implicaciones que la de éste: indignación ante el destructivo abuso de poder de la Iglesia e Instituciones Irlandesas, y especialmente ante la falta de humanidad y de consideración hacia el individuo. Por ejemplo, hemos visto cómo la señorita Martha Blake, que 
había consagrado toda su vida a satisfacer las exigencias de la fe católica, siente, al final de sus días, el abandono al que le someten las instituciones religiosas y hospitalarias. Su último pensamiento es "decepción", terrible palabra para una Iglesia y un Gobierno que se caracterizaron por un extremado celo en inculcar e imponer una moral que solo perseguía controlar al individuo, en vez de enriquecerlo más humanamente. Junto con Martha Blake, vimos también otras víctimas de esa moral y de las condiciones sociales del país, unas anónimas y otras con nombre como Miss Rosanna Ford, Miss Marnell, Pat Rourke, todas ellas partícipes de un conflicto en el que la falta de humanidad y la ingratitud siempre se encontraban en el bando ganador...y opresor.

El capítulo IV lo hemos dedicado a analizar la sátira clarkeana a través de un buen número de poemas, muchos de los cuales hemos parafraseado para una mejor explicación y comprensión de lo que Clarke quería transmitir a través de una poseía no siempre clara. Su sátira contribuye además a cerrar un poco más el eslabón entre la poesía gaélica y la poesía irlandesa contemporánea. Su fuerza reside en la forma en que Clarke disecciona moral e intelectualmente la realidad pública y política de la Irlanda de su tiempo.

Después de exorcizar los conflictos que le afligían, Clarke se siente espiritualmente liberado para acometer la crisis nerviosa que sufrió en su juventud. En su lucha particular contra la actitud de incompetencia de las instituciones irlandesas, nuestro autor no pasa por alto las instituciones psiquiátricas irlandesas, las cuales conoce de primera mano por haber pasado trece meses de su vida en una de 
ellas -el Hospital de Swift. Esta experiencia quedaría 'plasmada en Mnemosyne Lay in Dust (1966) y ha constituido el objetivo del capítulo V de esta tesis. Clarke no sólo nos muestra el tratamiento, tanto social como humano, que recibían los enfermos de este hospital, sino también el cuadro patológico con el que ingresa nuestro poeta y su paulatina recuperación. Sus miedos, sus deseos, y sus sueños son descritos casi cincuenta años después con una precisión asombrosa. Mnemosyne Lay in Dust no es solo el poema depositario del conflicto mental de Clarke, sino el reflejo de la situación en la que se encontraban los hospitales psiquiátricos irlandeses. A la hora de analizar los sueños de Clarke hemos echado mano de las teorías de Freud, cuya Teoría de los Sueños ha coincidido casi plenamente con las anotaciones que Clarke reseñó en sus libros de memorias.

En los capítulos de esta tesis, Clarke, a través de máscaras, de sí mismo y de personajes reales de su Dublín natal, revisa los problemas colectivos a los que el individuo irlandés se ha enfrentado. Él mismo sufrió en su propia piel la intransigencia de una Iglesia que nunca mostró la más mínima consideración no sólo hacia el individuo irlandés en general, sino hacia la mujer en particular, a quienes no llegó a conceder ese pequeño margen de dignidad que todo ser humano se merece. Austin Clarke, veraz portavoz de buena parte de la Irlanda del siglo XX, es además una muestra sincera y honesta de la liberación de los malos espíritus que suelen atormentar la conciencia de los escritores irlandeses. 
APÉNDICE 


\section{Obras de Austin Clarke}

a) Poetry

The Vengeance of Fionn. Dublin and London: Maunsel and Company, 1917.

The Fires of Baal. Dublin and London: Maunsel and Roberts Ltd., 1921.

The Sword of the West. Dublin and London: Maunel and Roberts Ltd., 1921.

The Cattledrive in Connaught and Other Poems. London: George Allen and Unwin Ltd., 1925.

The Collected Poems. London: George Allen and Unwin Ltd., 1936.

Night and Morning. Dublin: The Orwell Press, 1938.

Ancient Lights, Poems and Satires: First Series. Dublin: Bridge Press, 1955.

Too Great a Vine, Poems and Satires: Second Series. Dublin: Bridge Press, 1957.

The Horse Eaters, Poems and Satires: Third Series. Dublin: Bridge Press, 1960.

Later Poems. Dublin: Dolmen Press, 1961.

Forget-Me-Not. Dublin: Dolmen Press, 1962.

Flight to Africa and Other Poems. Dublin: Dolmen Press, 1963.

Mnemosyne Lay in Dust. Dublin: Dolmen Press, 1966.

Old-Fashioned Pilgrimage and Other Poems. Dublin: Dolmen Press, 1967.

The Echo at Coole and Other Poems. Dublin: Dolmen Press, 1968.

A Sermon on Swift and Other Poems. Dublin: Dolmen Press, 1968.

Orphide and Other Poems. Dublin: Dolmen Press, 1970.

Tiresias. Dublin: Dolmen Press, 1971.

Collected Poems. Dublin: Dolmen Press, 1974.

b) Novels

The Bright Temptation. London: George Allen and Unwin Ltd., 1932.

The Bright Temptation. Second Edition. Dublin: Dolmen Press, 1965. 
The Singing Men at Cashel. London: George Allen and Unwin Ltd., 1936

The Sun Dances at Easter. London: Andrew Melrose, 1952.

c) Plays

The Son of Learning: A Play in Three Acts. London: Allen and Unwin, 1927.

The Flame. London: Allen and Unwin, 1930.

Sister Eucharia. Dublin Magazine, 1938.

The Jewels, Dublin Magazine, 1938.

Black Fast. Dublin: Orwell Press, 1941

The Kiss. Dublin Magazine, 1942

As the Crow Flies. Dublin, 1943.

The Viscount of Blarney and Other Plays. Dublin: Bridge, 1944; London: Williams and Norgate, 1944.

The Second Kiss. Dublin: Bridge, 1946; London: Williams and Norgate, 1946.

The Plot Suceeds, a Poetic Pantomime. Dublin: Bridge, 1950

The Moment Next to Nothing: A play in three acts. Dublin: Bridge, 1953.

Collected Plays. Dublin: Dolmen Press, 1963.

Two Interludes. Dublin: Dolmen Press, 1968.

The Impuritans. Dublin: Dolmen Press, 1973.

The Third Kiss. Dublin: Dolmen Press, 1976.

Liberty Lane. Dublin: Dolmen Editions XXVII, 1978.

d) Memoirs

First Visit to England and Other Memories. Dublin: The Bridge Press, 1945. 
Twice Round the Black Church: Early Memories of Ireland and England. London: Routledge and Kegan Paul, 1962.

A Penny in the Clouds. London: Routledge and Kegan Paul, 1968.

\section{Poemas comentados en la presente tesis}

Pilgrimage and Other Poems:

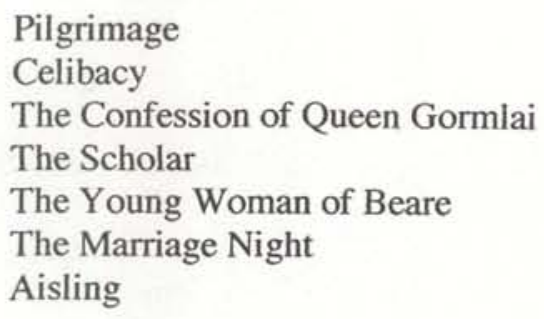

Collected Poems (1936)

Wandering Men

The Tales of Ireland

Night and Morning

Night and Morning

Mortal Pride

Tenebrae

Martha Blake

Repentance

The Lucky Coin

The Straying Student

Penal Law

Her Voice Could Not Be Softer

The Jewels

Ancient Lights

Celebrations

Marriage

Three Poems About Children 
Offerings

Bequests

Ancient Lights

Mother And Child

Emancipation

An Early Start

The Envy of Poor Lovers

Too Great a Vine, Poems and Satires

Usufruct

Wolfe Tone

The Trial of Robert Emmett

Past and Present

Nelson's Pillar, Dublin

Miss Marnell

Local Complainer

The Loss of Strength

Irish Mother

The Choice

Pilgrimage

The Horse-Eaters, Poems and Satires

Irish.American Dignitary

Knacker Rhymes

Flight to Africa

Burial of an Irish President

The Wounds of Fodhla

Precautions

A Simple Tale

Medical Missionary of Mary

Martha Blake at Fifty-one

Living on Sin

Unmarried Mothers

Cypress Grove

On the Mountain Tops

The Eighth Wonder of Ireland

Mnemosyne Lay in Dust 
Old-Fashioned Pilgrimage

Old Fashioned Pilgrimage

The Pill

The Redemptorist

The Echo at Coole and Other Poems

New Liberty Hall

In O'Connell Street

The Subjection of Women

Miss Rosanna Ford

The Vocation

A Sermon On Swfit

Orphide and Other Poems

Orphide

The Quarry 
BIBLIOGRAFÍA 
Adams, Michael. Censorship: The Irish Experience. Dublin: Scepter Books, 1968.

Bakhtin, Mikhail. Rabelais and His World. 1965. Trans. H. Iswolsky. Cambridge, MA: MIT P, 1968.

Bartlett, Thomas. “ 'What Ish my Nation?' Themes in Irish History 1550-1850.” Irish Studies. A General Introduction. Dublin: Gill and Macmillan, 1988. 44-59.

Barry, Peter. Beginning Theory. An Introduction to Literary and Cultural Theory. Manchester: Manchester University Press, 1995.

Beach, Sylvia. Shakespeare and Company. 1956. Lincoln: University of Nebraska Press, 1991.

Bradley, William Otis, Morris H. Needleman. An Outline - History of English Literature. Vol I. $4^{\text {th }}$. New York; Barnes and Nobles, 1952.

Brennan, Rory. "Contemporary Irish Poetry: An Overview." Poetry in Contemporary Irish Literature. Ed. Michael Kenneally. Gerrards Cross: Colin Smythe, 1995.

Brown, Terence. "Austin Clarke: Satirist." Ireland's Literature. Gigginstown, Mullingar: The Liliput Press Ltd., 1988. 127-140.

Brown, Terence. Ireland. A Social and Cultural History, 1922-1985. 1981. London: Fontana Press, 1985.

Clark, David. "“‘'A Joyce Tae Prick Ilka Pluke”: Joyce and the Scottish Renaisance". Papers on Joyce ns 5 (1999): 3-12.

Bullitt, John Marshall. Jonathan Swift and the Anatomy of Satire: A Study of Satiric Technique. Cambridge, MA: Harvard UP, 1953.

Clark, John Richard. The Modern Satiric Grotesque and Its Traditions. Lexington, KY: University Press of Kentucky, 1991.

Clarke, Austin. "The Gate." In the Prison of His Days: A Miscellany for Nelson Mandela. Ed. W. J. Mc Cormack. Gigginstown: The Lilliput Press, 1988. $72-5$.

--. The Collected Poems. London: George Allen and Unwin Ltd., 1936.

---. Collected Poems. Dublin: Dolmen Press, 1974. 
---. Mnemosyne Lay in Dust. Dublin: Dolmen Press, 1966.

-.. Poetry in Modern Ireland. Dublin: Colm Ó Lochlainn, 1951.

---. "Irish Poetry Today." Dublin Magazine X ns 1 (Jan. - March, 1935): 25-34.

--- Selected Poems. Ed. Thomas Kinsella. Winston-Salem: Wake Forest University Press, 1976.

---. Selected Poems. Ed. Hugh Maxton. Wiston-Salem: Wake Forest University Press, 1991.

--- First Visit to England and Other Memories. Dublin: The Bridge Press, 1945.

---. Twice Round the Black Church: Early Memories of Ireland and England. 1962. London: Routledge, 1990.

---. The Celtic Twilight and the Nineties. Dublin: Dolmen Press, 1969.

---. A Penny in the Clouds. 1968. London: Routledge, 1990.

Collins, Lucy. "Representation of Women in the Poetry of Austin Clarke." 1995. Trinity College Dublin. Tesis doctoral.

--- "Music in Mouth: Women and Language in the Poetry of Austin Clarke." Austin Clarke Remembered. Ed. R. Dardis Clarke. Dublin: The Bridge Press, 1996. 22-33.

Collins, Peter. "James Larkin." The Oxford Companion to Irish History. Ed. S.J. Connolly. Oxford: OUP, 1998.

Colum, Padraic. Introduction. The Collected Poems. By Austin Clarke. London: George Allen and Unwin Ltd., 1936. 12-18.

Connery, Brian A., ed. Theorizing Satire. Essays in Literary Criticism. New York: St. Martin's Press, 1995.

Connolly, S. J., ed. The Oxford Companion to Irish History. Oxford: OUP, 1998.

Cooney, Seamus. “Austin Clarke's ‘Celebration': A Commentary.” Eire-Ireland 2 (Summer 1967): 16-27.

Corish, Patrick. The Irish Catholic Experience: A Historical Survey. Dublin: Gill and Macmillan, 1985. 
Corcoran, Neil. After Yeats and Joyce. Oxford: OUP, 1997.

---. "The Blessings of Onan: Austin Clarke's Mnemosyne Lay in Dust." Irish University Review ns 13. 1 (Spring 1983): 43-53.

Corkery, Daniel. The Hidden Ireland: A Study of Gaelic Munster in the Eighteenth Century. Dublin: M. H. Gill, 1941.

Corráin, Donnchadh Ó. "Prehistoric and Early Christian Ireland." The Oxford History of Ireland. Ed. R. F. Foster. Oxford: OUP, 1992. 1-43.

Costello, Peter. The Heart Grown Brutal. Dublin: Gill and MacMillan, 1977.

Cruise O'Brian, C. Ancestral Voices. Religion and Nationalism in Ireland. Dublin: Poolbeg, 1994.

Davie, Donald. "Austin Clarke and Padraic Fallon". Two Decades of Irish Writing. Ed. Douglas Dunn. Pennsylvania: Dufour Editions, 1975. 37-35.

---. "Spring Verse Choice." Irish Writing ns 34 (Spring): 57-58.

---. "Insights and Epigrams." New Statement 62 (25 August): 246-47.

Deane, Seamus. "Irish Poetry and Irish Nationalism." Two Decades of Irish Writing. Ed. Douglas Dunn. Cheshire: Carcanet Press, 1975. 4-19.

---. "Unhappy and at Home: Interview with Seamus Heaney." Crane Bag 1, (Spring 1977): 64.

--.. Celtic Revivals. Winston-Salem: Wake Forest University Press, 1985.

---. A Short History of Irish Literature. London: Hutchinson, 1986.

Denman, Peter. "Austin Clarke: Tradition, Memory and Our Lot." Tradition and Influence in Anglo-Irish Poetry. Ed. Terence Brown and Nicholas Grene. London: Macmillan Press Ltd., 1989. 63-77.

Diez Fabre, Silvia. "North and South in Irish Identity: A Literary Approach to The Illusionist." El Discurso Artístico Norte y Sur: Eurocentrismo y Transculturalismos. Eds. José Luis Caramés Lage et al. Oviedo: Servicio de Publicaciones de la Universidad de Oviedo, 1998. 373-382.

Donogue, Denis. "Fire in the Great Vine." The New Review 1. 5 (1974): 69-71. 
---. "One More Brevity.” A Tribute to Austin Clarke. Dublin: Dolmen Press, 1966. 20-22.

Dorgan, Theo, ed. Irish Poetry Since Kavanagh. Dublin: Four Courts Press, 1996.

Ellmann, Richard. James Joyce. 1959. New York: OUP, 1983.

---. Yeats. The Man and the Masks. 1948. London: Penguin, 1979.

Eesthope, Antony. The Unconscious. London: Routledge, 1999.

Fallon, Brian. An Age of Innocence. Irish Culture 1930-1960. Dublin: Gill \& Macmillan, 1998.

Fallon, Patrick. "Current Poetry.” Dublin Magazine 31. II (1956): 18-23.

Fish, Stanley. Is There a Text In This Class? The Authority of Interpretive Communities. Cambridge: Harvard University Press, 1980.

Fitzgerald, David. "From Fantasy to Reality: An Aspect of the Life of Austin Clarke." Irish Socialist Review ns 2 (1975): 15-19.

-.-. The Two Irelands 1912-1939. Oxford: OUP, 1998.

Foster, R. F. Modern Ireland 1600-1972. 1988. New York: Penguin, 1989.

--, ed. The Oxford History of Ireland. Oxford: Oxford University Press, 1992.

Frazier, Adrian. “'The Cod-Bewildered Schoolboy': Austin Clarke's Later Poetry." Éire-Ireland ns 14. 2 (Summer 1979): 52-57.

Freud, Sigmund. Obras Completas. Tomo I. Madrid: Biblioteca Nueva, 1981.

Galván, Fernando. "La Narrativa Británica de Finales del Siglo XX: Cuestiones Históricas y Críticas". Márgenes y Centros en la Literatura Británica Actual. Ed. Fernando Galván. Alcalá: Universidad de Alcalá, 2000.

Gambra, Rafael. Historia Sencilla de la Filosofía. 22 edición. Madrid: Ediciones Rialp, 1997.

García Tortosa, Francisco, ed. James Joyce, Anna Livia Plurabelle. Madrid: Cátedra, 1992. 
García Tortosa, Francisco y Antonio Raúl de Toro Santos, eds. Joyce en España I. La Coruña: Universidad de la Coruña, 1994.

García Tortosa, Francisco. "Dublin y Finnegans Wake". El Dublín de James Joyce. Barcelona: Ediciones Destino, 1995.

---. "Ulysses de James Joyce: Clásico contemporáneo". Actas de las I Jornadas de Estudios Ingleses. Jaén: Universidad de Jaén, 1995.

Garrat, Robert F. Modern Irish Poetry. 1986. London: University of California Press, 1989.

--. "“Aware of my Ancestors': Austin Clarke and the Legacy of Swift." ÉireIreland 9. 2 (Summer 1976): 92-103.

--- "Austin Clarke in Transition." Irish University Review ns 4. 1 (Spring 1974): $100-16$.

Gibaldi, Joseph. MLA Handbook for Writers of Research Papers. $4^{\text {th }}$ ed. New York: The Modern Language Association, 1995.

Gifford, Don, Robert J. Seidman. Ulysses Annotated. Notes for James Joyce's Ulysses. London: University of California Press, Ltd., 1989.

González Casademont, Rosa. "Religion in Brian Moore's Novels. Ireland as Europe's Back of Beyond". Actas del XV Congreso de AEDEAN. Logroño: Universidad de la Rioja: 1991. 163-171.

---. "Religion and Power in Ireland." Culture and Power. Eds. Felicity Hand y Chantal Cornut-Gentille. Lleida, 1995.

---, ed. Culture and Power. Institutions. Barcelona: PPU, 1996.

---. "Irlanda del Norte. El Largo Camino hacia la Paz." Historia y Vida ns 363, XXXI (1998): 80-92.

-.-. "Northern Ireland. Beyond and the Green." Culture and Power. Cultural Confrontations. Ed. Chantal Cornut-Gentille D'Arcy. Zaragoza, 1999. 31-42.

Goodby, John. “'The Prouder Counsel of Her Throat': Towards a Feminist Reading of Austin Clarke." Irish University Review ns 29. 2 (Autumn/Winter 1999): 321-340. 
Grennan, Eamon. "American Relations." Irish Poetry Since Kavanağh. Ed. Theo Dorgan. Dublin: Four Courts Press, 1996. 95-105.

Halpern, Susan. Austin Clarke. His life and Works. Dublin: The Dolmen Press, 1974.

Harmon, Maurice. "The Later Poetry of Austin Clarke." The Celtic Studies: Studies in Irish Culture and Literature. Ed. Ray B. Brown, William John Roscelli, and Richard Loftus. New York: Books for Library Press, 1970. 39-55.

---. "Notes Towards a Biography." Irish University Review ns 4.1 (Spring 1974): 13-25.

---. Austin Clarke. A Critical Introduction. Dublin: Wolfhound Press, 1989.

Hughes, Kathleen. The Church in Early Irish Society. London: Methuen, 1966.

Hurtley, J. A. et al. Diccionario Cultural e Histórico de Irlanda. Barcelona: Ariel, 1996.

---. Ireland in Writing. Amsterdam: Rodopi, 1998

Inglis, Tom. Moral Monopoly: The Catholic Church in Modern Irish Society. Dublin: Gill and Macmillan, 1987.

Jeffares, Norman A. Anglo-Irish Literature. London: Gill and MacMillan, 1982.

Johnston, Dillon. Irish Poetry After Joyce. Indiana: University of Notre Dame Press, 1986.

--. A Portrait of the Artist as a Young Man. 1916. London: Paladin, 1990.

--.. The Critical Writings. 1959. Ed. Ellsworth Mason and Richard Ellmann. New York: Cornell University Press, 1989.

--.. Ulysses. 1922. London: Penguin, 1986.

-.-. Ulises. Trad. Francisco García Tortosa y María Luisa Venegas. Ed. Francisco García Tortosa. Madrid: Cátedra, 1999.

Kavanagh, Patrick. Self-Portrait. Dublin: Dolmen Press, 1964. 
Kennelly, Brendan, ed. The Penguin Book of Irish Verse. 1979. London: Penguin, 1981.

---."Poetry and Violence." History and Violence in Anglo-Irish Literature. Eds. Joris Duytschaever and Geert Lernout. Amsterdam: Editions Rodopi, 1988. 5-28.

Kenner, Hugh. A Colder Eye. New York: Penguin, 1984.

Kenny, Herbert A. Literary Dublin. 1974. Dublin: Gill and Macmillan, 1991.

Kiberd, Declan. Inventing Ireland. 1995. Cambridge: Harvard University Press, 1996.

-.. "Irish Literature and Irish History." The Oxford History of Ireland. 1989. Ed. R. F. Foster. Oxford: Oxford University Press, 1992. 230-281.

Kinsella, Thomas. "The Poetic Career of Austin Clarke." Irish University Review ns 4.1 (Spring 1974): 128-136.

-.-. "The Irish Writer." Davis, Mangan, Ferguson? Tradition and the Irish Writer. Ed. Roger McHugh. Dublin: Dolmen Press, 1970. 57-66.

--.- Introduction. Selected Poems. By Austin Clarke. Winston-Salem: Wake University Press, 1976.

Lausberg, Heinrich. Elementos de Retórica Literaria. 1975. Madrid: Editorial Gredos, 1983.

Lee, J.J. "Women and the Church Since the Famine." Women in Irish Society: The Historical Dimension. Eds. M. McCurtain and D. O'Conrain. Dublin: Arlen House, 1979. 37-45.

Lodge, David, ed. Modern Criticism and Theory. 1977. Great Britain: Athenaeum Press Ltd., 1997.

Longley, Edna. The Living Stream. Literature \& Revisionism in Ireland. New Castle upon Tyne: Bloodaxe Books Ltd., 1994.

Loftus, Richard. "Austin Clarke: Ireland of the Black Church." In Nationalism in Modern Anglo-Irish Poetry. Madison: University of Wisconsin Press, 1964. 258-77. 
---. Nationalism in Modern Anglo-Irish Poetry. Madison: University of Wisconsin Press, 1964.

Lucy, Sean. "The Poetry of Austin Clarke." Canadian Journal of Irish Studies ns 9.1 (1983): 5-21.

Lyons, F.S.L. Ireland Since the Famine. 1971. London: Fontana Press, 1985.

---. Culture and Anarchy in Ireland 1890-1939. Oxford: Clarendon Press, 1979.

McCormack, W.J. "Austin Clarke: The Poet as Scapegoat of Modernism." Modernism and Ireland: The Poetry of the 1930s. Ed. Patricia Coughlan and Alex Davis. Cork: Cork University Press, 1995. 75-102.

MacMinn, Joseph. "Literature and Religion in Eighteenth Century Ireland: A Critical Survey." Irish Writers and Religion. Ed. Robert Welch. Gerrards Cross: Colin Smythe, 1992. 15-31.

MacReamoinn, Seán. "Clarke and Broadcasting." Poetry Ireland Review, Special Austin Clarke Supplement ns 22/23 (1988): 159-164.

McHugh, Roger. "The Plays of Austin Clarke." Irish University Review ns 4. 1 (Spring 1974): 52-64.

Malcolm, Elizabeth. A History of St Patrick's Hospital, Dublin 1746-1989. Dublin: Gill and Macmillan, 1989.

Martin, Agustine. "Technique and Passion in Clarke's Mnemosyne." Poetry Ireland Review ns 22 \& 23 (Summer 1988): 97-104.

---. "The Rediscovery of Austin Clarke." Studies ns 104. 216 (Winter 1965): 408434.

---. "Clarke a Life." Austin Clarke Remembered. Ed. R. Dardis Clarke. Dublin: The Bridge Press, 1996. 66-82.

--.. "Kavanagh and After: an Ambiguous Legacy." Irish Poetry after Kavanagh. Ed. Theo Dorgan. Dublin: Four Courts Press, 1996. 21-34.

Maxton, Hugh. Introduction. “'Beyond the Pale': Introducing Austin Clarke (18961974)." Selected Poems. Wiston-Salem: Wake Forest University Press, 1991. 1-28. 
Mercier, Vivian H. S. "The Verse Plays of Austin Clarke." The Dublin Magazine ns 19.2 (April-June 1944): 39-47.

---. "Mortal Anguish, Mortal Pride. Austin Clarke's Religious Lyrics". Irish University Review ns 4.1 (Spring 1974): 91-99.

---. The Irish Comic Tradition. 1962. London: Souvenir Press, 1991.

Montague, John. A Tribute to Austin Clarke. Dublin: The Dolmen Press Limited, 1966.

---."Contemporary Verse: A Short Chronicle". Studies ns 47 (Winter 1958): 441449.

O'Brian, Conor Cruise. Voces Ancestrales. Religión y Nacionalismo en Irlanda. Prólogo Jon Juriasti. Madrid: Espasa Calpe, 1999.

6 Corráin, Donnchadh. "Prehistoric and Early Christian Ireland." The Oxford History of Ireland. Ed. R.F. Foster. Oxford: OUP, 1992. 1-25.

O'Callaghan, M. "Religion and Identity. The Church and Irish Independence." The Craner Bag 7.2 (1983): 65-67.

O'Farrell, Patrick. England and Ireland Since 1800. London: OUP, 1975.

Paglia, Camille. Sexual Personae. London; Penguin, 1991.

Petro, Peter. Modern Satire: Four Studies. Berlin: Mouton, 1982.

Praga, Inés. Una Belleza Terrible: La Poesía Irlandesa Contemporánea (19401995). Barcelona : PPU, 1996.

---. "Poetry and Satire in Contemporary Ireland: an Approach to Paul Durcan's Poetry". ES (Revista de Filología Inglesa) 19 (1995): 73-83.

Relihan, Joel C. Ancient Menippean Satire. Baltimore, MD: Johnd Hopkind UP, 1993.

Rodgers, W. R., ed. Irish Literary Portraits. London: British Broacasting Corp, 1972.

Rodriguez Palomero, Luisa Fernanda. " "The Dead", nocturno y cadencia final." Estudios Humanísticos de la Universidad de León (1996): 237-245. 
---. "Rosa Chacel Protraying the Artist after Joyce's Portrait of the Artist." Estudios Humanísticos de la Universidad de León (1998): 245-258.

Roscelli, William John. "The Private Pilgrimage of Austin Clarke." The Celtic Studies: Studies in Irish Culture and Literature. Ed. Ray B. Brown, William John Roscelli, and Richard Loftus. New York: Books for Library Press, 1970. 56-69.

Rosenheim, Edward W. Swift and the Satirist's Art. Chicago: The University of Chicago Press, 1963.

Riggliano, Lorraine. Austin Clarke. A Reference Guide. New York: G. K. Hall \& Co, 1993.

Saul, George Brandon. "The Poetry of Austin Clarke." The Celtic Cross: Studies in Irish Literature. Ed. Ray B. Brown, William John Roscelli, and Richard Loftus. New York: Books for Library Press, 1970. 26-38.

Schirmer, Gregory A. The Poetry of Austin Clarke. Dublin: Dolmen Press, 1983.

---. "Clarke as Literary Critic." Austin Clarke Remembered. Ed. R. Dardis Clarke. Dublin: The Bridge Press, 1996. 84-95.

---. Introduction. The Reviews and Essays of Austin Clarke. Gerrards Cross: Colin Smythe, 1995. ix-xix.

Scupham, Peter. "The Green and Gold Bow Tie." Agenda ns 14.4 - 15.1 (WinterSpring 1977): 147-152.

Seidel, Michael. Satiric Inheritance: Rabelais to Sterne. Princeton, NJ: Princeton UP, 1979.

Shaw, Francis. "Early Irish Spirituality: 'One Holy, Catholic and Apostolic'." Studies ns 52 (Summer 1963): 180-193.

Smyth, Gerry. The Novel and the Nation. Studies in the New Irish Fiction. London: Pluto Press, 1997.

Sutherland, James. English Satire. 1958. Cambridge: Cambridge UP, 1967.

Tapping, Craig G. Austin Clarke, A Study of His Writings. Dublin: The Academy Press, 1981. 
Thompson, Mary. "Austin Clarke and the Experience of Modernity, 1912-1922." Austin Clarke Remembered. Ed. R. Dardis Clarke. Dublin: The Bridge Press, 1996. 107-125.

Timson, Beth S. "Austin Clarke: The Poet's Image of Frustrated Love." Irish Renaissance Annual. Vol. III. Ed. Dennis Jackson. Toronto: Associate Univ. Press, 1982. 59 - 70.

Tuchman, Barbara. "When Does History Happen." Fields of Writing. Ed. Nancy R Comley et al. New York: St. Martin's Press, 1994. 225-232.

Valente, José Ángel. Variaciones sobre el Pájaro y la Red. Barcelona: Tusquets, 1991.

Vázquez Fernández, Antonio. Freud y Jung: Exploradores del Inconsciente. Serie Historia de la Filosofía, $\mathbf{n}^{\circ} 23$. Madrid: Editorial Cincel, 1986.

Welch, Robert. "Austin Clarke and Gaelic Poetic Tradition." Irish University Review ns 4.1 (Spring 1974): 41-51.

White, J. H. Church and State in Modern Ireland. Dublin: Gill and Macmillan, 1980.

Williams, Nicholas. "Literature in Irish." The Oxford Companion to Irish History. Ed. S.J. Connoly. Oxford: OUP, 1998. 321-324.

Woolf, Virginia, "Street Hunting." The Art of the Personal Essay. Ed. Philip Lopate. New York: Doubleday, 1995. 256-265.

Yeats, W. B. Yeats's Poems. Ed. A. Norman Jeffares. Dublin: Gill and MacMillan, 1989.

\section{WEBSITES}

www.allmovie.com. "Keystone Kops". 

